UNIVERSIDADE DE BRASÍLIA

INSTITUTO DE CIÊNCIAS BIOLÓGICAS

DEPARTAMENTO DE FITOPATOLOGIA

PROGRAMA DE PÓS-GRADUAÇÃO EM FITOPATOLOGIA

\title{
ANÁLISE GENÉTICA DA RESISTÊNCIA A Fusarium oxysporum f. sp. lactucae RAÇA 1 EM ALFACE: APLICAÇÃO DE MARCADORES DO TIPO RGA E DE SNPS DERIVADOS DE GENOTYPING-BY-SEQUENCING
}

CLÉIA SANTOS CABRAL

Brasília - DF 


\section{CLÉIA SANTOS CABRAL}

ANÁLISE GENÉTICA DA RESISTÊNCIA A Fusarium oxysporum f. sp. lactucae RAÇA 1 EM ALFACE: APLICAÇÃO DE MARCADORES DO TIPO RGA E DE SNPS DERIVADOS DE GENOTYPING-BY-SEQUENCING

Tese apresentada à Universidade de Brasília como requisito parcial para a obtenção do título de Doutora em Fitopatologia pelo Programa de PósGraduação em Fitopatologia.

Orientador

Dr. Leonardo Silva Boiteux

BRASÍLIA

DISTRITO FEDERAL - BRASIL

2016 


\section{FICHA CATALOGRÁFICA}

\section{Cabral, Cléia Santos.}

Análise genética da resistência a Fusarium oxysporum f. sp. lactucae raça 1 em alface: Aplicação de marcadores do tipo RGA e de SNPs derivados de Genotyping-by-sequencing. / Cléia Santos Cabral

Brasília, 2016.

Número de páginas 182p.

Tese de Doutorado. Programa de Pós-graduação em Fitopatologia, Universidade de Brasília, Brasília.

1. Lactuca sativa L., murcha de fusário, marcadores moleculares, seleção assistida, QTLs e Genotyping-by-sequencing.

I. Universidade de Brasília. PPG/FIT.

II. Análise genética da resistência a Fusarium oxysporum f. sp. lactucae raça 1 em alface: Aplicação de marcadores do tipo RGA e de SNPs derivados de Genotyping-by-sequencing. 
A minha amada avó Francisca Maria, mãe Terezinha Pereira e Tia Aurora (in memorian) pela força, ajuda, paciência e apoio 


\section{AGRADECIMENTOS}

À Deus e a Nossa Senhora pelo dom da vida, discernimento, sabedoria, paciência, força, foco, bençãos e por sempre me guiar por caminhos retos.

A minha mãe, avós (Francisca Maria e Cleonice Cabral), irmãos, padrasto e pai pelo apoio, pela ajuda, pelo amor incondicional, compreensão e paciência. Apesar de todas as minhas dificuldades e obstáculos na vida, todos vocês estiveram ao meu lado nesses momentos.

A toda minha família, tios, primos, sobrinha (Maria Eduarda), cunhadas e madrinha Cláudia por todo o carinho, pelos momentos de descontração e pela harmonia.

Aos meus orientadores Dr. Leonardo Silva Boiteux minha eterna gratidão por acreditar no meu potencial, pela sua valiosa orientação, pelas críticas construtivas, por proporcionar a chance de desenvolver esse trabalho e pelo enorme aprendizado; a A Dr. Maria Esther pela credibilidade nas minhas idéias, disponibilidade, paciência e por compartilhar vários dos seus conhecimentos comigo.

Ao Dr. Richard Michelmore e Dr. Maria Truco pela valiosa colaboração na execução deste trabalho e por sempre estarem dispostos a me receber e me ajudar durante meu treinamento na University of California Davis. Agradeço também ao Dr. Valter Oliveira (CNPH) pela ajuda nas análises genéticas do Cap. 2.

Ao Dr. Ailton Reis e ao Luis Galhardo pela amizade, incentivo, ensinamentos e pela cooperação.

Aos membros da banca examinadora, Adalberto Café Filho, Carlos Lopes, Hélcio Costa e Robert Miller pela criteriosa avaliação deste trabalho

Aos meus colegas e amigos da Embrapa Hortaliças, Luana, Fabiana, Chico, Amanda, Fred, Edivânio, Jadir Borges e José Getúlio pela ajuda nos experimentos, momentos de alegria e uma prazerosa convivência.

Ao meu querido amigo americano Joe Burns pela hospitalidade, amizade, disponibilidade, suporte e incentivo.

Aos amigos de Davis, Aurea, Oscar, Lia, Pablo, Júlio, Hector, Pedro, Diego, Juliana, Mira pela receptividade, acolhimento durante a minha estadia na Califórnia.

Aos meus amados amigos Tatiane, Maurício, Kátia, Elenice, Rayane, Carolina Forcada, Rafaela, Carolina

Bertuzzi, Débora, Raissa, Ivanildo, Sirlei, Geane, Niday, Priscila, Maíra, Roberta e Natália por sempre acreditarem na minha capacidade, pelo incentivo, carinho, amizade e palavras motivadoras nos momentos de superação durante essa tese.

Aos professores, funcionários e técnicos do curso de Pós-graduação em Fitopatologia.

A todos os amigos e colegas da pós-graduação, Luiz, Maria do Desterro, João, Sara, Carina, Cristiano, Mônica e Sofya por todos os momentos de alegria e descontração.

À Universidade de Brasília pela oportunidade de ingressar na pós-graduação.

A CAPES e CNPq pelo apoio financeiro pelas atividades desenvolvidas.

À Embrapa Hortaliças pela infraestrutura para a realização deste trabalho.

A todos aqueles que, de alguma forma, contribuíram para a realização deste trabalho. 
Trabalho realizado junto ao Departamento de Fitopatologia do Instituto de Ciências Biológicas da Universidade de Brasília, sob orientação do Dr. Leonardo Silva Boiteux, com apoio financeiro do Conselho Nacional de Desenvolvimento Científico e Tecnológico (CNPq) e da Coordenação de Aperfeiçoamento de Pessoal de Nível Superior (CAPES).

Análise genética da resistência a Fusarium oxysporum f. sp. lactucae raça 1 em alface: Aplicação de marcadores do tipo RGA e de SNPs derivados de Genotyping-by-Sequencing.

\title{
Cléia Santos Cabral
}

TESE APROVADA em 19/10/2016 por:

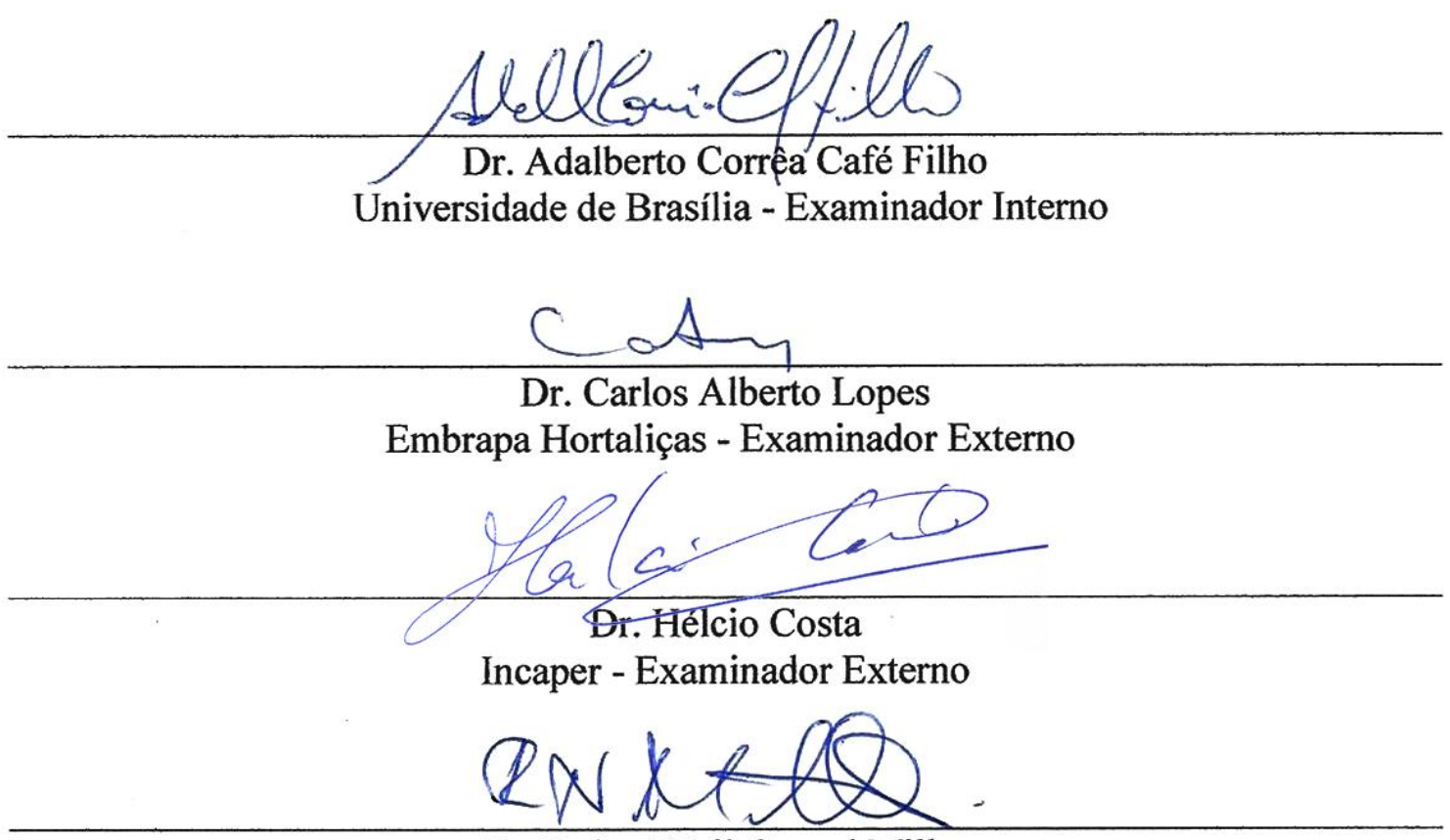

Dr. Robert Neil Gerard Miller

Universidade de Brasília - Examinador Interno

$$
\text { beonaido E. postex: }
$$

Dr. Leonardo Silva Boiteux

Embrapa Hortaliças - Orientador - Presidente

\author{
BRASÍLIA - DISTRITO FEDERAL \\ BRASIL




\section{SUMÁRIO}

\section{CAPÍTULO 1 - Revisão de literatura}

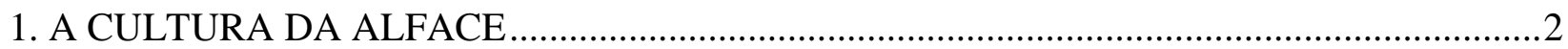

2. TIPOS VARIETAIS E O MERCADO BRASILEIRO DE ALFACE ........................................

3. HISTÓRICO DO MELHORAMENTO GENÉTICO DE ALFACE NO BRASIL ........................5

4. CLASSIFICAÇÃO BOTÂNICA E BIOLOGIA FLORAL .....................................................

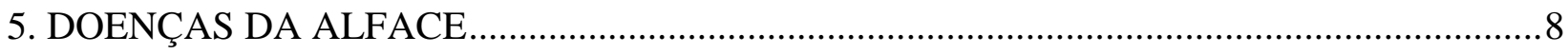

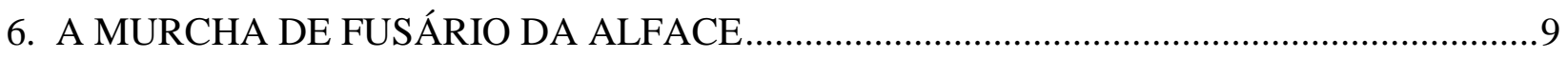

7. IMPORTÂNCIA DOS MARCADORES MOLECULARES NO MELHORAMENTO ...........13

8. SISTEMAS DE MARCADORES MOLECULARES NO MELHORAMENTO GENÉTICO 14

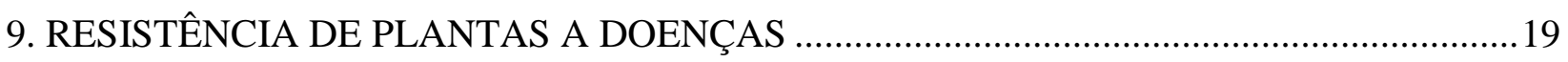

10. RESISTÊNCIA BASAL E RESISTÊNCIA MEDIADA POR GENES R …............................21

11. MECANISMOS ESTRUTURAIS E FUNCIONAIS DE GENES DE RESISTÊNCIA

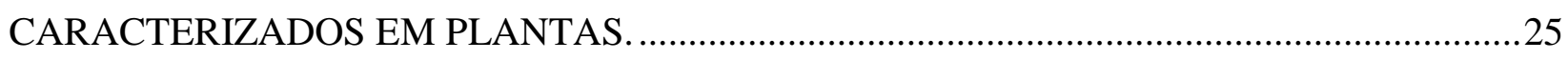

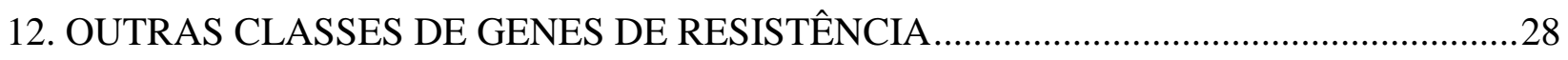

13. GENES ANALÓGOS DE RESISTÊNCIA (RGAS): ESTRUTURA, FUNÇÃO \&

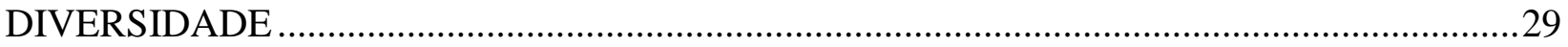

14. ANÁLISES DE GENES R CANDIDATOS E DE RGAS EM ALFACE .................................30

15. ABORDAGENS DE BIOINFORMÁTICA PARA IDENTIFICAÇÃO E CARACTERIZAÇÃO DE GENES DE RESISTÊNCIA E RGAS EM GENOMAS VEGETAIS

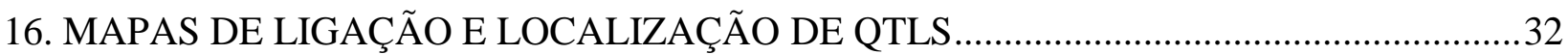

17. MAPAS GENÉTICOS E FERRAMENTAS GENÔMICAS DISPONÍVEIS PARA Lactuca

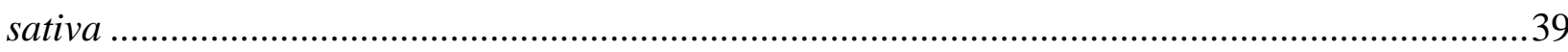

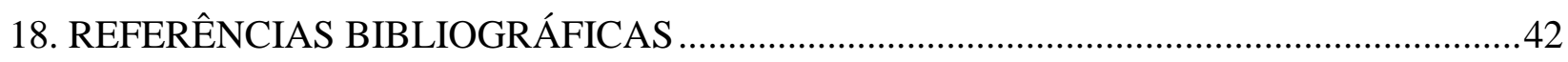

CAPÍTULO 2 - Herança da resistência à murcha de fusário (Fusarium oxysporum f. sp. lactucae raça 1) na cultivar de alface 'Vanda'

RESUMO .63

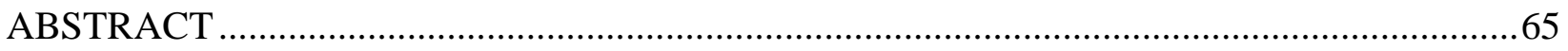

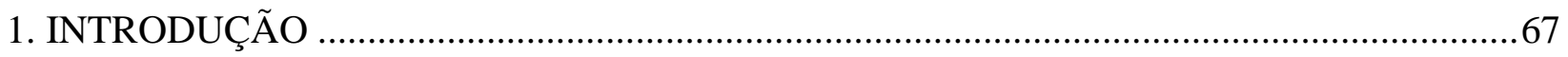

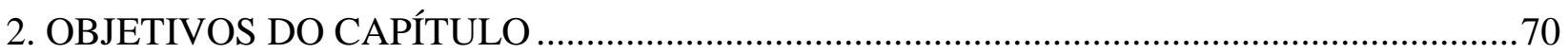

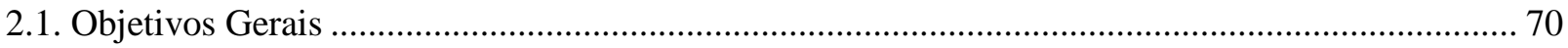

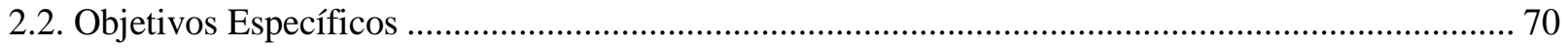


3.1. Cruzamentos entre parentais contrastantes para resposta a isolados FOLAC raça $1 \mathrm{e}$ desenvolvimento de populações segregantes para estudos de herança da resistência ......

3.2. Extração de DNA genômico de linhagens parentais e indivíduos das populações segregantes ....... 71

3.3. Desenvolvimento de marcadores moleculares para identificação de plantas híbridas no cruzamento

'Gizele' $x$ 'Vanda' com uma coleção de primers RAPD

3.4. Validação com amostras dos parentais e da população $\mathrm{F}_{1}$ de marcadores RAPD-SCAR ................ 72

3.5. Desenvolvimento de marcadores do tipo Sequence Characterized Amplified Regions (SCAR)...... 73

3.6. Sequenciamento dos amplicons clonados

3.7. Desenho dos oligonucleotídeos e amplificação dos potenciais marcadores do tipo Sequence

Characterized Amplified Regions (SCAR).

3.8. Caracterização fenotípica das linhagens parentais, híbridos $F_{1}$ e populações segregantes para resposta a resistência um isolado de FOLAC raça 1......................................................................... 75

3.9. Avaliação da resposta dos materiais genéticos de alface ao isolado de FOLAC raça 1 ................. 76

3.10. Validação dos marcadores moleculares entre os parentais contrastantes ..................................... 76

3.11. Emprego da estratégia de Bulked segregant analysis (BSA) para verificar potencial ligação com o(s) fator(es) de resistência a FOLAC raça 1 dos marcadores polimórficos entre os parentais contrastantes

4. RESULTADOS .77 4.1. Desenvolvimento de marcadores moleculares para identificação de plantas híbridas entre 'Gizele' e 'Vanda'. 77

4.2. Padrão de segregação de resistência para FOLAC raça 1 ............................................................... 77 4.3. Bulked segregant analysis (BSA) para verificar potencial ligação com o(s) fator(es) de resistência a FOLAC raça 1 dos marcadores polimórificos entre os parentais contrastantes .................................... 79

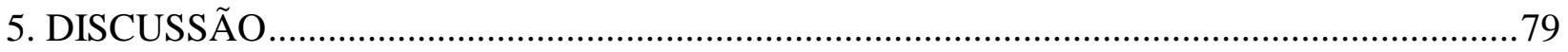

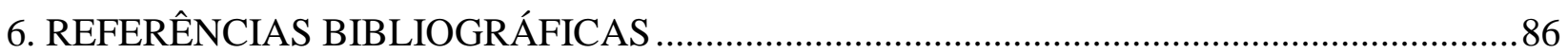

\section{CAPÍTULO 3 - Plataforma de marcadores DR analogs derivados de clusters gênicos do genoma da alface: Aplicação na localização de fatores de resistência a Fusarium oxysporum f. sp. lactucae (raça 1).}

RESUMO

ABSTRACT

1. INTRODUÇÃO

2. OBJETIVOS.

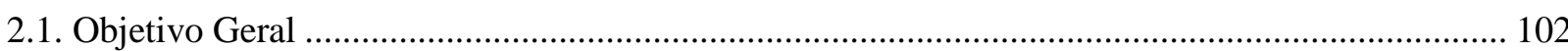

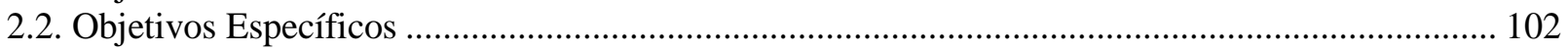

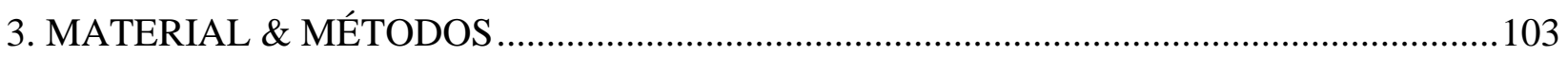

3.1. Cruzamentos entre parentais contrastantes para resposta a FOLAC raça 1 e desenvolvimento de

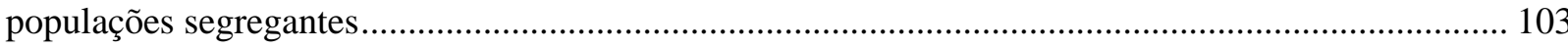

3.2. Caracterização fenotípica das linhagens parentais e populações segregantes ............................... 103

3.3. Extração de DNA de genômico de linhagens parentais e indivíduos das populações segregantes 104

3.4. Plataforma de marcadores do tipo Disease Resistance Analogs (DR analogs) em alface.............. 105

3.5. Reação de PCR com primers anelando em regiões dos cromossomos 1, 2, 4, 7 \& 8 contendo DR analogs ..... 


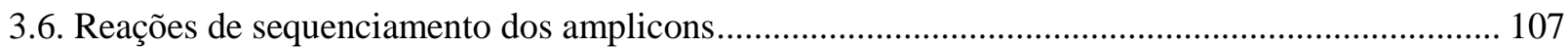

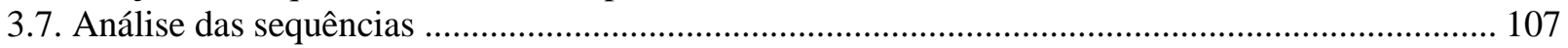

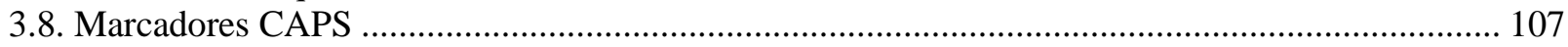

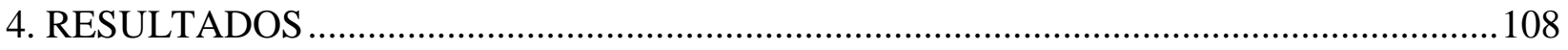

4.1. Genotipagem das linhagens parentais e da população $F_{2}$ para marcadores DR-analogs

potencialmente ligados a resistência a raça 1 de FOLAC .................................................................. 108

4.2. Análises Blast dos amplicons clonados e seqüenciados .............................................................. 108

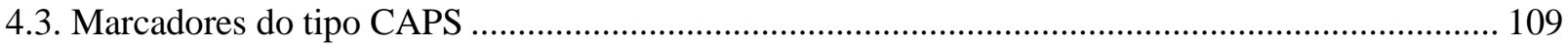

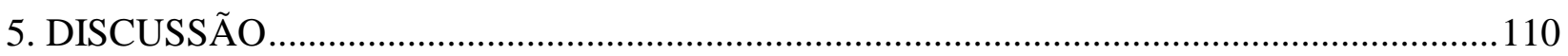

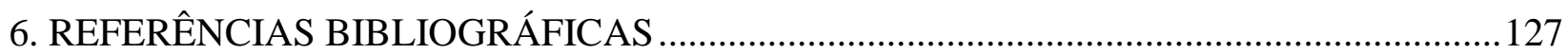

\section{CAPÍTULO 4 - Emprego da estratégia de genotyping-by-sequencing (GBS) visando identificar regiões genômicas ligadas à resistência de Fusarium oxysporum f. sp. lactucae raça $1 \mathrm{em}$ alface}

RESUMO

ABSTRACT

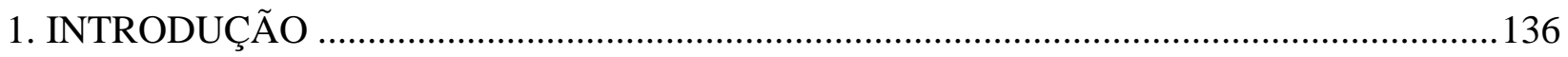

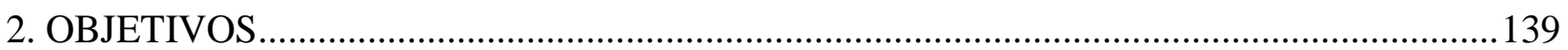

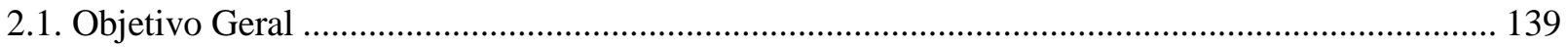

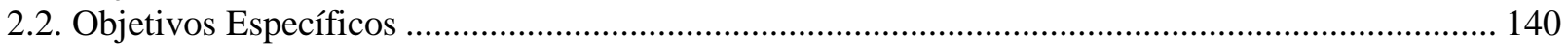

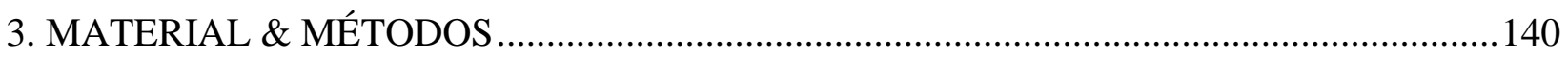

3.1. Parentais utilizados para a produção de populações segregantes .................................................. 140

3.2. Caracterização fenotípica das linhagens parentais e populações segregantes .............................. 140

3.3. Extração de DNA de genômico de linhagens parentais e indivíduos das populações segregantes 141

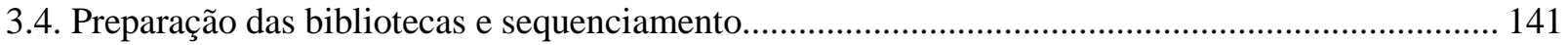

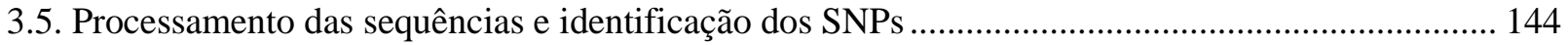

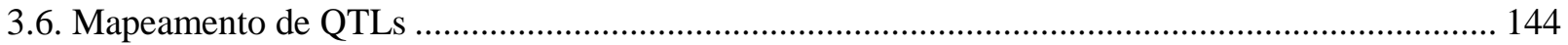

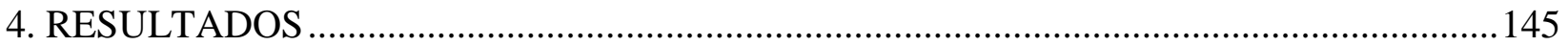

4.1. Genotipagem de marcadores moleculares e mapeamento de QTLs ........................................... 145

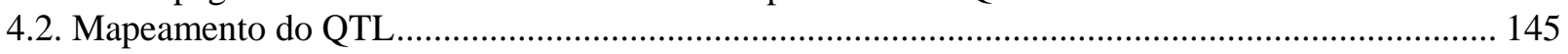

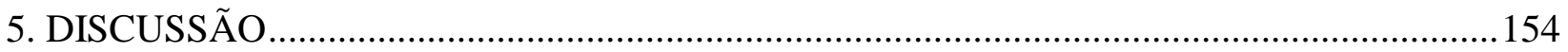

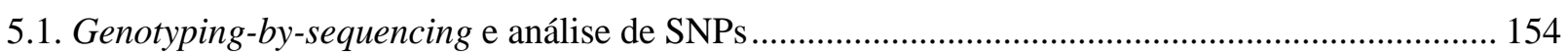

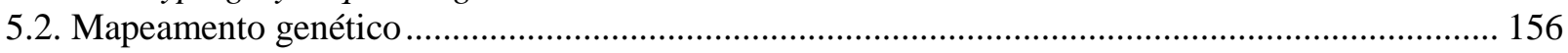

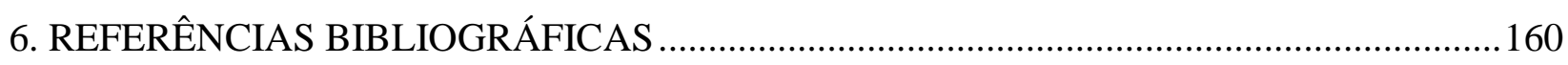




\section{LISTA DE TABELAS}

Tabela 2-1. Análise das respostas de plantas de alface (Lactuca sativa L.) a um isolado de Fusarium oxysporum f. sp. lactucae raça 1 nas gerações $F_{1}$ e $F_{2}$ obtidas do cruzamento entre os parentais 'Gizele' (suscetível) $x$ 'Vanda' (resistente) e ajuste dos dados dos padrões de segregação para um modelo de 3:1 de acordo o teste de do qui-quadrado $\left(x^{2}\right)$. 78

Tabela 3-2. Lista do subgrupo de 98 pares primers empregados, visando identificar marcadores associados com a resistência a Fusarium oxyporum $\mathrm{f}$. sp. lactucae (FOLAC) raça $1 \mathrm{em}$ alface. Esses marcadores foram derivados de sequências do tipo Resistance gene analogs (RGA) dispersas em dos cinco principais MRCs (major resistance clusters) do genoma da alface localizados nos cromossomos (Cr.)/grupos de ligação 1, 2, 4, 7 \& 8. Os pares de primers foram obtidos no site http://cgpdb.ucdavis.edu/GeneticMapViewer/display/ ou foram sintetizados a partir de sequências disponíveis no mesmo site. Marcadores do tipo SRR e SCAR previamente descritos por Simko et al. (2009) e Aruga et al. (2012) foram também incorporados nas análises.

Tabela 3-3. Resultados das buscas (via o algoritmo BLAST) de identidade das sequências dos amplicons derivados de um subgrupo de primers empregados, visando identificar marcadores ligados e/ou genes candidatos associados com a resistência a FOLAC raça $1 \mathrm{em}$ alface. Esses marcadores foram derivados de sequencias do tipo Resistance gene analogs (RGAs) estão dispersos em cinco dos principais MRCs (major resistance clusters) do genoma da alface localizados nos cromossomos (Cr.)/grupos de ligação $1,2,4,7 \& 8$

Tabela 3-4. Recombinantes encontrados na análise dos marcadores moleculares testados em indivíduos da população $\mathrm{F}_{2}$ de alface.

Tabela 4-1. Mapa genético da população $F_{2}$ do cruzamento entre os genitores de alface contrastantes 'Gizele' (suscetível) $x$ 'Vanda' (resistente) para resistência a Fusarium oxysporum f. sp. lactucae (FOLAC) raça 1.

Tabela 4-2. QTLs para resistência a Fusarium oxysporum f. sp. lactucae (FOLAC) raça 1 (com suas designações de acordo com as notas de severidade identificados em populações $\mathrm{F}_{2}$ e $\mathrm{F}_{3}$ derivadas do cruzamento entre genitores de alface contrastantes 'Gizele' (suscetível) $x$ 'Vanda' (resistente). 148

\section{LISTA DE FIGURAS}

Figura 2-1. Perfil de amplicons gerados com um subconjunto de primers RAPD dos grupos OP-A e OP-B (Operon) usando como molde o DNA genômico dos genitores de alface contrastantes para resistência a Fusarium oxysporum f. sp. lactucae (FOLAC) raça 1 ['Vanda', resistente e 'Gizele', suscetivel]. Duas cultivares de alface do segmento varietal Americana ('Laurel' e 'Raider'), também foram incluídas (como padrões) nessas análises. O código ' $M$ ' indica a linha do marcador de peso molecular $1 \mathrm{~kb}$ plus DNA ladder (Invitrogen).

Figura 2-2. Perfil de amplicons obtido com o par de primers SCAR OPW-15-3 para os genitores contrastantes para resistência a Fusarium oxysporum f. sp. lactucae (FOLAC) raça 1 
['Vanda' (V), resistente e 'Gizele' (G), suscetivel]. A eletrofore em gel de agarose $(1,2 \%)$ ilustra o padrão de bandas para ' $V$ ' e ' $G$ ' e para 11 plantas potencialmente de natureza híbrida $F_{1}$ (códigos 1, 2, 3, 5, 6, 8, 9, 12, 11 \& 17) obtidas de cruzamentos controlados entre ' $\mathrm{G}$ ' $x$ ' $\mathrm{V}$ '. $\mathrm{O}$ código ' $\mathrm{M}$ ' indica a linha do marcador de peso molecular $1 \mathrm{~kb}$ plus DNA ladder (Invitrogen). A seta aponta uma banda polimórfica informativa (originária de 'Vanda') que foi utilizada para distinguir plantas verdadeiramente de origem híbrida $F_{1}$ (ex. as assinaladas com barras) de plantas de 'Gizele' autofecundadas (ex. 5, 6, $11 \& 17$ ), quando empregando a cultivar 'Vanda' como doadora de pólen e 'Gizele' como receptora de pólen. .85

Figura 3-1. Padrão de amplicons gerado pelos primers testados. Análise em gel de agarose 1,5\%. MM - Marcador Molecular 1Kb Plus DNA Ladder (Invitrogen). F: fenótipo de alface (Lactuca sativa L.) observado (resistente ou suscetivel). G: Genotipagem pelo marcador em questão considerando R o padrão da cultivar 'Vanda' (V) e S o padrão da cultivar 'Gizele' (G) e padrão heterozigoto $(\mathrm{H})$.

Figura 3-2. Desenho de um marcador CAPS (Cleaved Amplified Polymorphic Sequence) baseado na sequência obtida pela amplificação com o primer LE0351. Abaixo a sequência obtida após amplificação da cultivar de alface (Lactuca sativa L.) 'Gizele' com o sítio de restrição da enzima MspA1. Acima o segmento mostrando o mapa de restrição para o amplicon de 'Vanda' (sem MspA1) e 'Gizele' (com MspA1). 124

Figura 3-3. Desenho de um marcador CAPS (Cleaved Amplified Polymorphic Sequence) baseado na sequência obtida pela amplificação com o primer LE0337. Abaixo a sequência obtida após amplificação da cultivar de alface (Lactuca sativa L.) 'Vanda' com o sítio de restrição da enzima $B s t \mathrm{~N} 1$. Acima o segmento mostrando o mapa de restrição para o amplicon de 'Vanda' (com Bst $\mathrm{N} 1)$ e 'Gizele' (sem Bst $\mathrm{N} 1$ ).....

Figura 3-4. Desenho de um marcador CAPS (Cleaved Amplified Polymorphic Sequence) baseado na sequência obtida pela amplificação com o primer M4241. Abaixo a sequência obtida após amplificação da cultivar de alface (Lactuca sativa L.) 'Gizele' com o sítio de restrição da enzima Msel. Acima o segmento mostrando o mapa de restrição para o amplicom de 'Vanda' (sem Msel) e 'Gizele' (com Msel).

Figura 4-1. Sequência de adaptadores contendo o barcode específico para cada amostra e o sítio de restrição para AvalI.

Figura 4-2. Molde do mapa genético de alface no cromossomo 9. As 82 plantas $F_{2}$ foram obtidas do cruzamento entre genitores de alface contrastantes 'Gizele' (suscetível) $x$ 'Vanda' (resistente) para resistência a Fusarium oxysporum f. sp. lactucae raça 1. As linhas correspondem as distintas localizações cromossômicas e as colunas da correspondem os genótipos da população $\mathrm{F}_{2} \mathrm{em}$ cada local. $\mathrm{O}$ genótipo " $\mathrm{A}$ " corresponde ao parental feminino ('Gizele'), "B" para o parental masculino ('Vanda'), "H" para heterozigoto, e "_." para os missing data. Um total de 38 scaffolds foram posicionados nesse cromossomo.

Figura 4-3. Molde do mapa genético de alface no cromossomo 4. As 82 plantas $F_{2}$ foram obtidas do cruzamento entre genitores de alface contrastantes 'Gizele' (suscetível) $x$ 'Vanda' (resistente) para resistência a Fusarium oxysporum f. sp. lactucae raça 1. As linhas correspondem as distintas localizações cromossômicas e as colunas da correspondem os genótipos da população $\mathrm{F}_{2} \mathrm{em}$ cada local. $\mathrm{O}$ genótipo "A" corresponde ao parental feminino 
('Gizele'), “B” para o parental masculino ('Vanda'), "H” para heterozigoto e ', -' para os missing data. Um total de 92 scaffolds foram posicionados nesse cromossomo.

Figura 4-4. QTLs ligados a resistência à murcha de fusário da alface causada por Fusarium oxysporum f. sp. lactucae raça 1 posicionados nos grupos de 8 (4a) e 16 (9a). As linhas verticais azul, roxa, vermelha e verde indicam o limite de significância estatística (LOD) de acordo com a população empregada $\left(\mathrm{F}_{2}\right.$ e $\left.\mathrm{F}_{3}\right)$ e as notas de severidade.

Figura 4-5. QTL ligado a resistência à murcha de fusário da alface causada por Fusarium oxysporum f. sp. lactucae raça 1 posicionado entre os marcadores [Lsat_1_v5_g4_2792 a Lsat_1_v5_g4_1990] no grupo de ligação 8 (Cromossomo 4a). (LOD = 6.02). As linhas verticais azul, roxa, vermelha e verde indicam o limite de significância estatística (LOD) de acordo com a população empregada $\left(\mathrm{F}_{2}\right.$ e $\left.\mathrm{F}_{3}\right)$ e as notas de severidade.

Figura 4-6. QTLs ligados à resistência à murcha de fusário da alface causada por Fusarium oxysporum f. sp. lactucae raça 1 posicionado entre os marcadores [Lsat_1_v5_g9_108)\}, [Lsat_1_v5_g9_111 e Lsat_1_v5_g9_448] no grupo de ligação 16 (Cromossomo 9a). (LOD $=4.77$ e $\mathrm{LOD}=6,61$, respectivamente). As linhas verticais azul, roxa, vermelha e verde indicam o limite de significância estatística (LOD) de acordo com a população empregada $\left(\mathrm{F}_{2}\right.$ e $\left.\mathrm{F}_{3}\right)$ e as notas de severidade.

Figura 4-7. Localização no mapa genético da alface dos três QTLs associados com à resistência a Fusarium oxyporum f. sp. lactucae raça 1 derivados da cultivar de alface 'Vanda'. As barras indicam as regiões significativas associados com a resistência ao patógeno. 


\section{RESUMO GERAL}

\section{Cabral, Cléia Santos. ANÁLISE GENÉTICA DA RESISTÊNCIA A Fusarium oxysporum f.}

sp. lactucae RAÇA 1 EM ALFACE: APLICAÇÃO DE MARCADORES DO TIPO RGA E DE SNPS DERIVADOS DE GENOTYPING-BY-SEQUENCING. 2016. 182p. Doutorado em Fitopatologia - Universidade de Brasília, DF.

A alface (Lactuca sativa L.) é uma das hortaliças mais importantes no Brasil e no mundo. A murcha de fusário (causada por distintas raças do fungo Fusarium oxysporum f. sp. lactucae FOLAC) é uma das principais doenças de da alface em regiões tropicais e subtropicais. Devido à dificuldade de implementação de estratégias eficazes de controle químico e cultural, o uso de cultivares com resistência genética é o método mais prático de manejo da doença. Fontes estáveis de resistência à raça FOLAC 1 foram encontradas, mas a base genética dessa característica ainda se encontra mal caracterizada. A integração da seleção assistida por marcadores (SAM) em programas de melhoramento convencional irá acelerar o desenvolvimento e lançamento de cultivares de alface com resistência genética a esse patógeno. O presente estudo teve como objetivos: elucidar os fatores genéticos associados à resistência a murcha de fusário (Capítulo 2) e idenficar marcadores moleculares potencialmente ligados aos fatores de resistência a isolados de FOLAC raça 1 identificados na cultivar 'Vanda' (Capítulo 3). O estudo da herança genética da resistência a FOLAC raça 1 foi conduzido com populações segregantes $\left(F_{2}\right.$ e $\left.F_{3}\right)$ obtidas do cruzamento entre um parental suscetível 'Gizele' e 'Vanda'. Populações foram inoculadas com uma suspensão de esporos do patógeno ( $3 \times 10^{6}$ microconídios $\left./ \mathrm{mL}\right)$ por meio de corte e imersão de raízes e avaliadas quanto à resistência por meio de escala de notas. O DNA genômico das plantas resistentes e suscetíveis foi extraído e usado como molde em diferentes sistemas de marcadores (RAPD, SCAR, DR analogs, SRR e CAPS), visando identificar polimorfismos ligados a essa característica. Com relação à resistência a FOLAC raça 1, os estudos indicaram um 
controle genético relativamente simples na cultivar 'Vanda', com os resultados de segregação indicando um locus monogênico com uma provável combinação de efeitos de dosagem e penetrância incompleta. No entanto, os diferentes sistemas de marcadores moleculares utilizados nessa primeira etapa do trabalho não permitiram encontrar polimorfismos com estreita ligação com o(s) fator(es) de resistência. Desta forma, uma nova etapa do trabalho foi conduzida visando identificar por meio do método genotyping-by-sequencing (GBS) marcadores moleculares ligados a resistência (Capítulo 4). O GBS foi explorado na identificação de SNPs (single nucleotide polymorphisms) empregando DNA extraído dos dois parentais e de um conjunto de 82 indivíduos da população $F_{2}$ derivados do cruzamento entre 'Vanda' $x$ 'Gizele'. Cada indivíduo foi genotipado utilizando o Illumina Hiseq 3000, que produziu 4,5 milhões de reads por amostra. Um total de 10.017 SNPs foi identificado entre os parentais. Estes SNPs foram avaliados para ligação com o fenótipo de resistência nos 82 individuos $F_{2}$. Os dados genotípicos foram condensados em 1.484 scaffolds ou supercontigs. Um subconjunto de 417 scaffolds contendo polimorfismos foi selecionado para a construção de um mapa de ligação após filtragem baseada em missing data $(<20 \%)$, teste de qui-quadrado $(3: 1$ p $>0,05)$ e número de SNPs por scaffold. O mapa foi composto por 17 grupos de ligação, com um comprimento total de $1.132,984 \mathrm{cM}$. A análise de QTL (quantitative trait loci) para resistência a FOLAC raça 1 foi realizada no mapa de ligação com os conjuntos de dados de severidade da doença obtido nas populações $F_{2}$ e $F_{3}$. Dois QTLs de efeito maior foram identificados no cromossomo 9, explicando 30 a $40 \%$ da variação fenotípica observada na população $F_{3}$ e $F_{2}$, respectivamente. Um QTL de efeito menor foi detectado no cromossomo 4 , explicando $0,06 \%$ da variação fenotípica na população $F_{3}$. Desta forma, o presente estudo estabelece a porção mediana do cromossomo 9 como sendo a localização física do principal locus de resistência para FOLAC raça 1 presente na cultivar 'Vanda'. Portanto, os marcadores moleculares localizados na proximidade desta região genômica 
são candidatos para o desenvolvimento de ferramentas de SAM em programas de melhoramento genético visando incorporar essa característica em linhagens elite de alface.

Palavras-chave: Lactuca sativa L., murcha de fusário, marcadores moleculares, seleção assistida, QTLs. 


\section{GENERAL ABSTRACT}

Cabral, Cléia Santos. Genetic analysis and mapping of resistance to Fusarium oxysporum f. sp. lactucae race 1 in lettuce: Employment of the RGA marker system and SNPs derived from genotyping-by-sequencing strategy. 2016. 182p. Doctor Degree in Plant Pathology Universidade de Brasília, DF.

Lettuce (Lactuca sativa L.) is one of the most important leafy vegetable crops in Brazil and worldwide. Fusarium wilt (caused by distinct races of the fungus Fusarium oxysporum f. sp. lactucae - FOLAC) is one of the main soil-borne diseases of lettuce in tropical and subtropical regions. Due to the complexity of implementing effective cultural and chemical control, the most practical disease management strategy has been the use of cultivars with genetic resistance. Stable sources of resistance to FOLAC race 1 have been found, but the genetic basis of this trait is yet poorly characterized. The integration of marker assisted selection (MAS) in conventional breeding programs would be an important contribution to accelerate the development and release of lettuce cultivars with genetic resistance to this pathogen. In this context, the present study aimed to elucidate the inheritance of resistance to FOLAC race 1 detected in the cultivar Vanda (Chapter II) and to search for molecular markers linked to FOLAC race 1 resistance factor(s) (Chapter III). Inheritance studies were carried out using segregating populations $\left(F_{2}\right.$ and $F_{3}$ families) derived from the cross between a susceptible cultivar (Gizele) and a FOLAC race 1 resistant cultivar (Vanda). The parental lines and the segretating populations were inoculated via root dipping technique with a conidial suspension adjusted to $3 \times 10^{6}$ microconidia/mL. Reaction to one FOLAC race 1 isolate was evaluated using a disease rating scale ranging from 1 (= no symptoms) to 5 (= dead plant). The studies indicated a simple genetic control of FOLAC race resistance in cultivar Vanda, with segregation results indicating a single gene locus with a likely 
combination of dosage effects and incomplete penetrance. Genomic DNA of resistant and susceptible plants was extracted and used as a template in PCR assays with different marker systems (RAPD, SCAR, DR Analogs, SSRs and CAPS) aiming to identify polymorphisms linked to the resistant reaction. However, none of the evaluated molecular techniques were able to identify markers in close linkage with the resistance factor(s). Therefore, a new phase of the present study was conducted with the objective of searching for markers linked to resistance through the employment of the genotyping-by-sequencing (GBS) strategy (Chapter IV). The GBS strategy was employed using DNA extracted from the parental lines and 82 phenotyped $\mathrm{F}_{2}$ individuals derived from the same cross between Gizele $x$ Vanda. Each individual was genotyped using the Illumina Hiseq 3000. A total of 4.5 million reads was obtained per sample with 10,017 SNPs being identified among the parental lines as well as among the $82 \mathrm{~F}_{2}$ individuals. Genotypic data were condensed into 1484 scaffolds. Four hundred seventeen (417) scaffolds containing polymorphisms were selected for the construction of the linkage map after filtering based on missing data $(<20 \%)$, chi-square test $(3: 1 \mathrm{p}>0.05)$ and number of SNPs per scaffold. The final map consisted of 17 linking groups with a total length of 1,132.984 cM. The QTL analysis for resistance to FOLAC race 1 was performed on the linkage map based upon the disease severity datasets of $F_{2}$ population and $F_{3}$ families. Two major effect QTLs were identified on chromosome 9, explaining 30 to $40 \%$ of the phenotypic variation observed in the population $\mathrm{F}_{3}$ and $\mathrm{F}_{2}$, respectively. One QTL of minor effect was also identified on chromosome 4, explaining 0.06\% of the phenotypic variation in the $\mathrm{F}_{3}$ population. This study establishes the central region of chromosome 9 as the physical location of a major resistance locus to FOLAC race 1 found in Vanda. Molecular markers in close proximity to this genomic region are candidates for the development of MAS tools for breeding programs aiming to incorporate this trait into elite lettuce lines. 
Keywords: Lactuca sativa L., Fusarium wilt, molecular markers, assisted selection, QTLs mapping. 


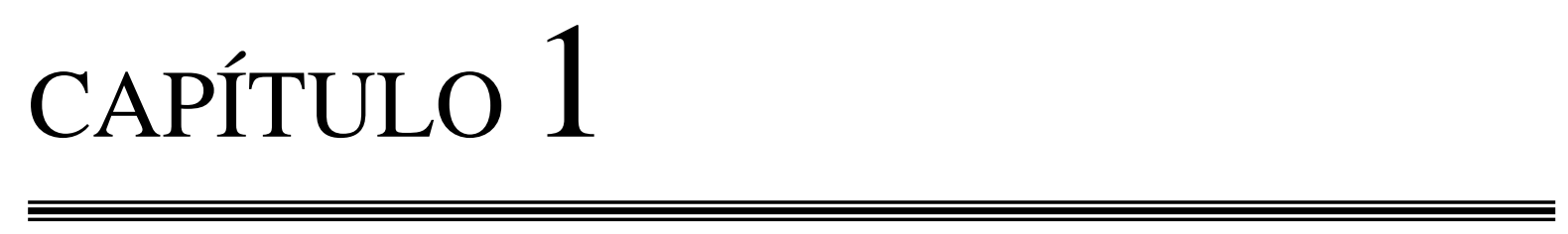
REVISÃO DE LITERATURA 


\section{A CULTURA DA ALFACE}

A alface (Lactuca sativa L.) pertence à família Asteraceae, subfamília Cichorioideae e tribo Lactuceae (Ryder, 1999). A Asteraceae (previamente denominada de Compositae) é a maior família dentro das dicotiledôneas, contendo cerca de 23.000 espécies distribuídas por mais de 1.500 gêneros (Almeida, 2006).

A alface é uma das mais importantes hortaliças folhosas cultivadas no mundo. A produção mundial em 2010 foi de mais de 23 milhões de toneladas. A Ásia produziu aproximadamente 65\%, seguida de 19\% na América Central e do Norte e 13\% na Europa. A área restante foi cultivada na América do Sul, na África e na Oceania, cada uma contribuindo com $1 \%$ da produção total (Simko, 2013). Os Estados Unidos são o maior produtor de alface com as regiões produtoras se localizando na região central da Califórnia (70-75\%) e no Arizona (18-20\%) (Simko, 2013, 2014). Por ser o principal componente de saladas ou mix de saladas, o agronegócio de alface nos Estados Unidos é considerado como um dos dez economicamente mais valiosos do país, somando US\$ 2 bilhões por ano (Kandel, 2015). Na China e no Egito, além das folhas, os caules são também consumidos cozidos ou crus, em conserva, como sopas, desidratados ou na composição de molhos (Mou, 2008).

A possibilidade de cultivos sucessivos no mesmo ano, um consolidado hábito de consumo alimentar pela população e uma demanda sempre crescente do produto são fatores que fazem da alface a hortaliça folhosa mais produzida no Brasil, conferindo a essa cultura uma grande importância econômica e social (Sala \& Costa, 2016). Além disso, a alface apresenta grande aceitação no mercado não só por suas qualidades organolépticas, mas também por possuir baixo valor calórico e ser rica em sais de cálcio e de ferro e em vitaminas A, B1, B2, B6 e C (Oliveira et al., 2006). 
O centro de origem e domesticação da alface é o sul da Europa e a Ásia Ocidental, sendo cultivada desde 2500 a.C. (Ryder, 1999). A alface foi introduzida no Brasil no século XVI, por meio dos imigrantes portugueses (Filgueira, 2008). Do ponto de vista do melhoramento genético, a viabilização do cultivo da alface em regiões tropicais e subtropicais (com temperaturas mais elevadas e precipitações pluviométricas mais frequentes) envolveu a superação de uma série de obstáculos via incorporação de um conjunto de características para melhor adaptação desta hortaliça. Nas condições ambientais dos trópicos e subtrópicos, cultivares de alface com baixa adaptação não conseguem expressar o potencial genético plenamente, ocorrendo emissão prematura do pendão floral (= antecipação da fase reprodutiva) e redução drástica do ciclo da cultura, que comprometem a qualidade e a produção (Sala \& Costa, 2016). Segundo Silva et al. (1999), as temperaturas ideais para a produção de folhas e a formação da cabeça de alface estão entre 12 e $22^{\circ} \mathrm{C}$. Temperaturas acima desse limite favorecem $\mathrm{o}$ florescimento (pendoamento) precoce das plantas. $\mathrm{O}$ florescimento precoce provoca o alongamento do caule, estimula a produção de látex (que confere sabor amargo às folhas), reduz o número de folhas e afeta a formação de cabeça (Silva et al., 2000; Sala \& Costa, 2016).

\section{TIPOS VARIETAIS E O MERCADO BRASILEIRO DE ALFACE}

A planta da alface é herbácea de caule carnoso e esverdeado, ao qual se aderem às folhas. Conforme a cultivar, as folhas podem se apresentar lisas ou crespas, formando ou não "cabeça", com coloração em vários tons de verdes, ou roxa. Segundo Filgueira (2008), as cultivares podem ser agrupadas em seis diferentes tipos ou segmentos varietais: (1) Tipo Repolhuda - Crespa (= Americana): As folhas são caracteristicamente crespas, bem firmes e com nervuras destacadas, formando uma cabeça compacta. As folhas internas são mais crocantes que as externas, sendo preferidas para sanduíches. Exemplos: 'Lucy Brown', 'Laurel', 'Raider Plus', 'Tainá' e 
'Rafaela'; (2) Tipo Repolhuda - Manteiga: As folhas são bem mais lisas, muito delicadas, de coloração verde amarelada e aspecto amanteigado, formando uma cabeça tipicamente compacta. Exemplos: 'White Boston', 'Carolina', 'Elisa' e 'Lídia'; (3) Tipo Solta - Lisa: As folhas mais macias, lisas e soltas, não havendo formação de cabeça. Exemplos: 'Babá de Verão', 'Regina', 'Luisa' e 'Vitória de Santo Antão'; (4) Tipo Solta - Crespa: As folhas são firmes, crespas e soltas, não formando cabeça. Folhas com superfície inteiramente irregular com destaque para as bordas (que se apresentam inteiramente onduladas). Exemplos: 'Vanda', 'Verônica', 'Vera', 'Mônica' e 'Gizele'. A Embrapa Hortaliças em parceria com a empresa Agrocinco liberou recentemente três cultivares nesse segmento ('BRS Leila', 'BRS Lélia' e 'BRS Mediterrânea'); (5) Tipo Mimosa: As folhas são delicadas e com aspecto muito recortado. É um tipo varietal recente e que vem adquirindo certa relevância. Exemplos: 'Red Salad Bowl' e 'Mimosa'. (6) Tipo Romana: As folhas são alongadas, com nervuras bem protuberantes, formando cabeças pouco densas. É um tipo muito demandado em processamento e na produção de mix de folhas, bastante utilizados por restaurantes. De todas as alfaces citadas, é a menos consumida no Brasil, mas apresenta ampla aceitação na Europa e nos EUA. Exemplos: 'Romana Paris', 'Donna' e 'Sofia'.

Até meados da década de 1980, o mercado consumidor no Brasil tinha preferência pela alface lisa do tipo 'White Boston' ou 'manteiga'. Posteriormente, houve uma mudança de mercado para o segmento de alface do tipo crespa 'Grand Rapids'. Nos últimos anos, a alface do grupo varietal americana tem mostrado o maior crescimento no mercado. Esse segmento foi estabelecido com maior intensidade no Brasil, inicialmente, para atender às redes de fast food. Entretanto, a preferência por esse grupo varietal também tem aumentando pelos consumidores domiciliares (Sala \& Costa, 2012). O aumento observado no consumo de alface do tipo americana se deve principalmente às suas características organolépticas superiores em termos de 
crocância e sabor diferenciado (Sala \& Costa, 2012). Os tipos varietais 'Mimosa' e 'Romana' também apresentam um consumo crescente no Brasil, sendo demandados por restaurantes e processadores de hortaliças. Outro grupo varietal crescente é formado pelas cultivares coloridas, como os segmentos do tipo 'Crespa roxa' e 'Crespa vermelha', e o segmento de alface do tipo 'Mimosa Roxa' (Henz \& Suinaga, 2009; Sala \&Costa, 2012). A grande diversificação de tipos varietais de alface contribui para o aumento de seu consumo, além de ser uma importante forma de agregar valor em vários elos da cadeia produtiva. A disponibilidade de um amplo portfólio de cultivares capazes de atender aos diferentes tipos de mercados consumidores, com variados níveis de exigência e diferentes níveis financeiros, tem resultado na expansão do consumo desta hortaliça (Silva, 2009; Sala \& Costa, 2012).

\section{HISTÓRICO DO MELHORAMENTO GENÉTICO DE ALFACE NO BRASIL}

Os programas de melhoramento da alface para condições tropicais e subtropicais têm como foco o desenvolvimento de cultivares mais adaptadas e com resistência múltipla a doenças. Esse trabalho tem permitido plantar e colher alface de boa qualidade nas condições brasileiras durante todo o ano (Filgueira, 2008).

O melhoramento genético de alface no Brasil foi formalmente estabelecido pelo Professor Marcílio de Souza Dias na ESALQ em 1953, que propiciou o lançamento da cultivar 'Gorga' ('Great Lakes' x 'Batávia Blonde'). A 'Gorga' foi considerada, na época, como um conceito revolucionário uma vez que foi a primeira cultivar que combinava espessura foliar, arquitetura de planta aberta, tolerância ao pendoamento precoce e adaptação ao verão chuvoso, sem formação de cabeça. O fator limitante para seu cultivo foi sua suscetibilidade ao tip burn (deficiência na translocação de cálcio causando pela queima de bordas das folhas externas) e má formação de cabeça no cultivo de verão (Sala \& Costa, 2016). 
Posteriormente, outras importantes contribuições no melhoramento dessa cultura foram feitas pelo Dr. Hiroshi Nagai, do Instituto Agronômico de Campinas (IAC), com o cruzamento da cultivar lisa 'White Boston' com a cultivar romana 'Galega', resistente ao potyvírus Lettuce mosaic virus (LMV). Cultivares de alface lisa resistentes ao LMV e com tolerância ao pendoamento precoce foram obtidas nesse programa. Das várias progênies selecionadas, a que se destacou foi a cultivar 'Brasil 48'. A maior limitação dessa cultivar foi a sua baixa adaptação ao cultivo de verão, que ocasionava muitas perdas devido o apodrecimento das plantas e formação de cabeça (Sala \& Costa, 2016).

Na década de 1980, o Professor Dr. Cyro Paulino da Costa assumiu o programa de melhoramento genético de hortaliças da ESALQ. Em continuidade ao melhoramento genético de alface lisa foi liberada em 1985 a cultivar 'Regina', caracterizada por ser resistente ao LMV, apresentar plantas de grande porte (ausência de formação de cabeça) e tolerância ao cultivo no verão chuvoso. Essa alface foi lançada para o domínio público e todas as empresas do setor de sementes multiplicaram suas sementes e comercializaram-nas no mercado nacional.

O conceito de alface aberta no cultivo de verão permitiu o desenvolvimento do segmento de alface do tipo crespa 'Grand Rapids', mais adaptada ao cultivo verão. A partir da década de 1990 esse tipo de alface ganhou importância no país (Sala \& Costa, 2016). O lançamento das cultivars 'Verônica' e 'Vera' (tipo crespa 'Grand Rapids') pela equipe liderada pelo Dr. Paulo T. Della Vecchia da Agroflora S.A. (Della Vecchia et al., 1999) permitiu o cultivo de alface no verão em todo o Brasil. Essas cultivares foram a sustentabilidade da alfacicultura por décadas, devido ao pendoamento lento, não formação de cabeça, resistente as chuvas de verão, fácil manuseio e transporte e ciclo curto. Com isso o melhoramento genético de alface realizado no país, até então concentrado nas instituições públicas, passou a ser realizado pela iniciativa privada. 
Posteriormente, a empresa Sakata Seed Sudamerica lançou a cultivar 'Vanda' e passou a ser a empresa líder na produção na produção de sementes de alface com $70 \%$ do mercado.

Entre os anos de 1992 a 1993 o Engenheiro Agrônomo Carlos Alberto M. Tavaraes passou a trabalhar com o desenvolvimento de alface americana, restrita a região de Mogi-São Paulo em plantios de inverno. Ele avaliou mais de 300 acessos de alface americana e somente duas ('Lucy Brown' e 'Raider') foram selecionadas para as condições brasileiras.

Nos últimos anos diferentes empresas tais como: Sakata, TopSeed, Horticeres, Feltrin, Takii, Sakama, Hortec, Eagle e Enza Zaden vêm desenvolvendo e validando inúmeras cultivares de alface de diferentes tipos varietais e com resistência a fitopatógenos, evidenciando que esse processo precisa ser contínuo em razão das demandas futuras do setor. Duas cultivares do segmento crespa uma da Horticeres, como a cultivar Marisa e outra da Sakata, a cultivar Valentina apresentam resistência a murcha de fusário da alface. A Embrapa Hortaliças também iniciou um programa de melhoramento genético de alface de maneira informal em 2005 e que foi posteriormente formalizado com um projeto em parceria com a empresa Agrocinco em 2012/2013. Recentemente, três cultivares do segmento varietal crespa ('BRS Leila', 'BRS Lélia' e 'BRS Mediterrânea') foram liberadas dentro desse programa.

\section{CLASSIFICAÇÃO BOTÂNICA E BIOLOGIA FLORAL}

Das quase 100 espécies pertencentes ao gênero Lactuca, apenas quatro podem cruzar entre si, formando um grupo: a espécie domesticada $L$. sativa L. e as selvagens $L$. serriola L., $L$. saligna L. e L. virosa L., utililizadas em programas de melhoramento genético dessa hortaliça (Lebeda et al., 2014). A alface é uma espécie diploide com $2 \mathrm{n}=2 \mathrm{x}=18$ cromossomos e com um genoma de $2.7 \mathrm{~Gb}$, um dos maiores do reino vegetal (Arumuganathan \& Earle, 1991; The Lettuce Genome Sequencing Consortium, http: //Igr.genomecenter.ucdavis.edu) 
A alface apresenta inflorescência do tipo capítulo composta por aproximadamente 10 a 25 floretes ou flores. Cada flor apresenta um óvulo que, subsequentemente, formará um só aquênio. Devido aos dispositivos botânicos presentes na estrutura floral, a alface é uma espécie estritamente autógama. Dependendo da temperatura e da luminosidade do ambiente, o conjunto de flores do capítulo abre na parte da manhã, a partir das oito horas, e se fecham após as dez. No período de duas horas da antese, o pistilo se diferencia e, ao passar pelo tubo de anteras, é autopolinizado (dispositivo botânico de cleistogamia). Por esse motivo, não existe a produção comercial de sementes híbridas de alface, devido à sua biologia floral. Para realizar as hibridações (cruzamentos) artificiais controlados, os floretes do capítulo devem ser despolinizados (= emasculação parcial) via limpeza com jatos de água. Esse método não garante 100\% de eficiência, resultando, ainda, em frequências variáveis de sementes autofecundadas. Após, os floretes são secados e polinizados com o pólen de outra cultivar de interesse. Após o cruzamento, a flor que recebeu o pólen é identificada com os dados dos cruzamentos (Sala et al., 2014). Portanto, a superação dos dispositivos botânicos de autogamia representa um fator determinante na formação de populações segregantes dos programas de melhoramento genético da alface.

\section{DOENÇAS DA ALFACE}

Mais de 75 doenças da alface causadas por bactérias, fungos, nematóides e vírus já foram relatadas no mundo. Segundo Blacard et al. (2006) e Lopes et al. (2010) as doenças da parte área que mais causam danos a alface durante o seu ciclo produtivo são: Mancha bacteriana [Pseudomonas cichorii (Swinglle) Stapp], Míldio [Downy Midew-Bremia lactucae Regel], Antracnose [Microdochium panattonianum (Berl.)], Septoriose [Septoria lactucae Passerini], Mancha de cercóspora [Cercospora longissima (Cugini.) Sacc.], Podridão de botrytis [Botrytis 
cinerea Pers], Oídio [Powdery mildew - Golovinomyces cichoraceatum sensu stricto $=$ Erysiphe cichoracearum DC)], Mancha bacteriana [Xanthomonas campestris pv. vitians (Brown) Dye], Mosaico [Lettuce mosaic virus-LMV], Vira-cabeça [várias espécies: (Tomato spotted wilt virus TSWV), (Tomato chlorotic spot virus - TCSV) e (Groundnut ringspot virus - GRSV)], Mosqueado [Lettuce mottle virus - LeMoV] e Engrossamento-das-nervuras [(Big-vein-Lettuce big vein virus - LBVV) e (Mirafiori lettuce big-vein virus - MLBVV)], Lettuce Dieback [Tomato bushy stunt virus - TBSV e Lettuce necrotic stunt virus - LNSV] e outras viroses [(Cucumber mosaic virus - CMV) e (Turnip mosaic virus - TuMv)].

As doenças que afetam a raiz e o caule limitantes para o cultivo da alface são: Pythium spp., Sclerotinia minor Jagger, S. sclerotiorum (Lib.) de Bary, Rhizoctonia solani Khun, Thielaviopsis basicola (Berk.\& Broome) Ferraris, Podridão-mole [Pectobacterium spp. ou Dickeya $=$ Erwinia spp (Jones) Waldee], Nematóide das galhas [Meloidogyne spp.], Root downy Midew [Plasmopara lactucae-radicis (Stang. \& Gilbn)], murcha de vertícilio [Verticillium dahliae Kleb] e Murcha de fusário [Fusarium oxyporum Schlechtend.:Fr. f. sp. lactucae Matuo \& Motohashi-FOLAC] (Blacard et al., 2006; Lopes et al., 2010).

\section{A MURCHA DE FUSÁRIO DA ALFACE}

A murcha de fusário ou fusariose (causada por raças do fungo Fusarium oxysporum, Schlenchtend. f. sp. lactucae Matuo \& Motohashi) é uma das doenças economicamente mais importantes da alface ao redor do mundo. Os danos na produção podem variar de 20 a $70 \%$, dependendo da cultivar, das práticas de manejo adotadas e das condições ambientais (Pasquali $\boldsymbol{e} t$ al., 2005; 2007). Os sintomas iniciais dessa doença são um amarelecimento foliar e/ou redução do crescimento. Com o progresso da doença, as folhas mais velhas podem murchar totalmente, levando ao colapso e morte da planta. Cortes no sentido vertical do caule de plantas doentes 
permitem a visualização de uma coloração marrom intensa nos vasos condutores que aparece como resultado da reação da planta hospedeira à colonização e produção de toxinas pelo fungo $F$. oxysporum f. sp. lactucae (FOLAC) (Fujinaga et al., 2001; Garibaldi et al., 2004b; Scott et al., 2010).

A fusariose da alface tem uma ampla distribuição geográfica já foi relatada no Japão (Matuo \& Motohashi, 1967), nos Estados Unidos (Hubbard \& Gerik, 1993), em Taiwan (Huang \& Lo, 1998), no Irã (Millani et al., 1999), na Itália (Garibaldi et al., 2002), em Portugal (Pasquali et al., 2007), no Brasil (Ventura \& Costa, 2008; Cabral et al., 2012) e, mais recentemente, na Argentina (Malbrán et al., 2014) e na Holanda (Gilardi et al, 2016). Quatro raças de FOLAC foram identificadas, sendo que a raça 1 é a mais disseminada em todo o mundo, com relatos na Itália, em Portugal, nos EUA (Pasquali et al., 2005) e no Brasil (Cabral et al., 2014). O Japão é o único país onde três raças (1, 2 \& 3) já foram registradas (Fujinaga $\boldsymbol{e t}$ al., 2001, 2003; Yamauchi et al., 2004). Fora do Japão, a raça 3 foi relatada apenas em Taiwan (Lin et al., 2014). A raça 4 foi recentemente reportada na Holanda (Gilardi et al., 2016).

A determinação de raças de FOLAC se baseia na capacidade dos isolados induzirem (ou não) sintomas em um conjunto de cultivares de alface diferenciais ou diferenciadoras (Ogiso $\boldsymbol{e t}$ al., 2002; Fujinaga et al., 2003), e que consiste em uma abordagem trabalhosa e demorada, envolvendo a produção de mudas, produção de inóculo, inoculação controlada e avaliação da resposta das plantas.

No gênero Fusarium, a identificação de espécies baseada exclusivamente em características biológicas ou morfológicas representa um enorme desafio que, em geral, resulta em classificações imprecisas. O gênero Fusarium é especialmente difícil para taxonomistas devido à ausência de características morfológicas informativas e a instabilidade fenotípica de várias das características de valor no diagnóstico que são fortemente afetadas pelas condições de cultivo in 
vitro ou in vivo (Fravel et al., 2003). Neste sentido, o desenvolvimento de marcadores moleculares baseados em PCR para determinação de raças de FOLAC tem se mostrado muito útil para aumentar a precisão do diagnóstico e para permitir a análise em larga escala de coleções de isolados, uma vez que são menos trabalhosos e abreviam, consideravelmente, o tempo de obtenção dos resultados (Pasquali et al., 2007; Mbofung \& Pryor, 2010), incluindo a amplificação do DNA com marcadores do tipo Sequence characterized amplified region - SCAR (Lievens $\boldsymbol{e t}$ al., 2008). Um destes marcadores (Pasquali $\boldsymbol{e t}$ al., 2007) foi desenvolvido em regiões entre retrotransposons, os chamados Long Terminal Repeats (LTRs). Essa região denominada Han foi encontrada distribuída em todo o genoma de Fusarium (Huan-Van et al., 2000). Estudo realizado por Cabral et al. (2014) demonstrou que o par de primers Hani e Hanilatt3rev pode ser utilizado para identificar isolados brasileiros de FOLAC raça 1. Outros métodos utilizados para diferenciar e identificar populações de FOLAC, como a amplificação de uma região codificadora do fator de elongação-1 $\alpha$ (TEF-1 $\alpha$ ), de uma região da pequena subunidade mitocondrial (mtSSU rDNA) e a região espaçadora intergênica do DNA ribossômico (IGS) (Mbofung et al., 2007). A região IGS é particularmente adequada para estudos de relações intra-específicas de $F$. oxyporum, por ser muito informativa (Mbofung et al., 2007; Srinivasan et al., 2010).

Está bem estabelecido na literatura que as distintas formae speciales de $F$. oxysporum são eficientemente transmitidas por sementes (Mbofung et al., 2010; Sousa et al., 2015). De fato, a detecção de isolados de FOLAC raça 1 em vários países geograficamente distantes em um período de tempo relativamente curto sugere a sua recente dispersão mundial tenha ocorrido principalmente via sementes infectadas (Garibaldi et al., 2004a). Da mesma forma, a presença da raça 1 de FOLAC em distintas regiões produtoras de alface do Brasil sugere que este patógeno pode ter sido introduzido e disseminado dentro do país por meio de sementes 
infectadas/infestadas. Este fato é preocupante e alerta para a necessidade de um melhor controle fitossanitário das sementes importadas pelo Brasil.

O controle da murcha de fusário da alface através do uso de fungicidas ou da desinfestação dos solos com produtos químicos é, geralmente, pouco eficiente e inviável em termos econômicos e/ou ambientais. Estratégias de controle biológico estão sendo implementadas com isolados não patogênicos de $F$. oxysporum e com outros microrganismos antagônicos tais como Tricoderma harzianum (Innocenti et al., 2014).

Adicionalmente, a presença de fungos no solo pode ser controlada pela manipulação do ambiente por meio da utilização da solarização, da fumigação do solo e da rotação de cultura para reduzir os níveis de inóculo do solo (Matheron, 2015). A persistência de FOLAC no solo pode não ser afetada se as culturas empregadas em sistemas de rotação com alface permitirem o desenvolvimento ou a sobrevivência do patógeno (Gordon \& Koike et al., 2015). Pesquisas realizadas por Scott et al. (2013) mostraram que FOLAC pode colonizar raízes de tomate, melancia, algodão, brócolis e espinafre sem causar sintomas da doença. De qualquer forma, a medida de rotação de cultura é de pouca eficiência, uma vez que é um fungo de solo, podendo sobreviver no campo por 10 anos ou mais, mesmo na ausência do hospedeiro, uma vez que pode crescer em matéria orgânica.

Por essas razões, as táticas de manejo mais eficazes da doença se baseiam em estratégias de prevenção e incluem: uso de sementes isentas do patógeno, uso de material propagativo sadio, remoção de solo contaminado, limpeza prévia de tratores, equipamentos agrícolas, tubos de irrigação, equipamentos de colheita e calçados. No entanto, a estratégia preferencial de prevenção e controle da doença é o uso de cultivares resistentes (Gordon \& Koike et al., 2015).

O conhecimento sobre a variabilidade genética de FOLAC no Brasil é uma importante informação para o melhoramento genético visando incorporar fatores (alelos) de resistência que 
sejam efetivos contra todas as variantes (raças) desse patógeno. Isso subsidiará o desenvolvimento de cultivares com um espectro de resistência mais amplo, podendo prevenir problemas relacionados com potenciais surtos epidêmicos causados por variantes desse patógeno, ainda não reportadas no Brasil (Cabral \& Reis, 2013). Essa informação também é importante para os produtores e extensionistas, orientando-os na seleção e escolha de cultivares resistentes e com melhor adaptação a uma dada região produtora (Cabral \& Reis, 2013). A transmissão do fungo através de sementes e as perdas econômicas causadas pela fusariose também indicam a necessidade dos programas de melhoramento genético implementarem estratégias de ‘piramidação' de fatores genéticos distintos (do tipo raça-específicos) em uma única cultivar, incluindo, de maneira antecipatória (preemptive breeding), fatores que controlam resistência mesmo contra raças ainda não reportadas no Brasil.

\section{IMPORTÂNCIA DOS MARCADORES MOLECULARES NO}

\section{MELHORAMENTO}

Um marcador genético para ser útil em programas de seleção assistida deve apresentar os seguintes atributos: polimorfismo com elevado nível de especificidade (para um genótipo, fenótipo e região genômica ou gene); estabilidade e herança simples (Collard et al., 2005; Collard \& Mackill, 2008). Os marcadores moleculares ideais são aqueles denominados funcionais, ou seja, derivados ou localizados dentro dos próprios genes que controlam a característica de interesse.

O mapeamento genético de uma espécie consiste na geração de um conjunto ordenado de informações sobre as sequências do DNA que cobrem a totalidade ou um segmento de uma região do genoma. O mapeamento genético estima a frequiência de cotransmissão de dois marcadores ou genes. As probabilidades de permutas genéticas ocorrerem entre dois marcadores 
ou genes são menores quanto mais próximos estes estiverem localizados. Tal fato, torna possível ordenar linearmente a informação genética ao longo dos cromossomos. Ou seja, o mapa genético consiste na representação da ordem e da distância entre genes em grupos de ligação genética (Collard et al., 2005; Collard \& Mackill, 2008).

O emprego de marcadores moleculares propicia a seleção mais rápida de plantas superiores permitindo, inclusive, que novos cruzamentos possam ser realizados ainda dentro de uma mesma geração, aumentando significativamente a eficiência de um programa de melhoramento (Collard et al., 2005; Collard \& Mackill, 2008). Marcadores moleculares podem ser utilizados mesmo que não tenham sido ainda mapeados, contanto que possam estar fortemente associados com um dado genótipo ou fenótipo, comprovando o seu valor de diagnóstico (Milach, 1998).

Vários genes de resistência a doenças foram isolados/clonados, utilizando as estratégias de mapeamento genético/físico de alta resolução. Esse tipo de trabalho tem o objetivo de encontrar marcadores moleculares próximos $(=$ ligados $)$ ao gene de interesse, saturando com o maior número possível de marcadores a região do genoma onde o gene candidato se localiza. Esse processo foi acelerado/facilitado em algumas espécies de plantas cujos genomas completos já estão disponíveis (Collard $\boldsymbol{e t}$ al., 2005). Desta forma, a informação sobre a estrutura de genes de resistência a fungos possibilita o estabelecimento de métodos mais simplificados e eficientes, baseados na identidade de sequência com genes homólogos/análogos, visando a busca dos “genes candidatos" (Collard et al., 2005; Michelmore et al., 2013).

\section{SISTEMAS DE MARCADORES MOLECULARES NO MELHORAMENTO}

\section{GENÉTICO}

Diversos tipos de sistemas de marcadores moleculares são empregados na alface, incluindo, RAPD (Randomly Amplified Polymorphic DNA), SCAR (Sequence Characterized Amplified 
Regions), AFLP (Amplified fragment length polymorphism), CAPS (Cleaved Amplified Polymorphic Sequence), SSR (Simple Sequence Repeats - Microssatélites) e SNPs (Single Nucleotide Polymorphisms) (Kesseli et al., 1991; Jeuken et al.; 2001; Truco et al., 2007; Simko, 2009). Alguns marcadores foram encontrados em estreita ligação com segmentos genômicos contendo fatores que controlam importantes características de interesse para o melhoramento da alface, incluindo genes de resistência a doenças (Simko, 2013).

O sistema de marcadores RAPD (Randomly Amplified Polymorphic DNA), baseado na PCR, foi utilizado em vários estudos genéticos (Castagnone-Sereno et al., 1994; D’Andrea et al., 2008). Os marcadores RAPD são predominantemente dominantes de natureza binária (presença ou ausência de bandas ou amplicons) (Ferreira \& Grattapaglia, 1998). A análise via RAPD, além de utilizar pequenas quantidades de material genético (6-30 ng de DNA), não necessita do conhecimento prévio do genoma ou do fenótipo a ser estudado (Williams et al., 1990). As principais limitações dos marcadores RAPD é o baixo conteúdo de informação genética gerado em cada análise e a baixa reprodutibilidade dos resultados.

Os marcadores baseados nas regiões amplificadas de sequências caracterizadas (Sequence Characterized Amplified Regions - SCAR) foram desenvolvidos como o objetivo de eliminar algumas das desvantagens dos marcadores RAPD. O marcador SCAR é um fragmento de DNA genômico em um locus específico que é identificado por amplificação em PCR, usando-se um par de primers específicos (Sakiyama, 1993). Se um fragmento amplificado por meio do RAPD for de interesse, ele é clonado e as suas duas extremidades, sequenciadas. Essas informações são utilizadas para a construção de dois primers específicos com aproximadamente 24 nucleotídeos, que resultam em amplificação reproduzível desses loci quando altas temperaturas de anelamento são utilizadas. As vantagens dos marcadores SCAR sobre os marcadores RAPD é que eles detectam de maneira específica somente um locus; sua amplificação é menos sensível às 
condições experimentais/laboratoriais e podem ser potencialmente transformados em marcador codominante.

CAPS (Cleaved Amplified Polymorphic Sequence) são fragmentos de DNA amplificados via PCR, utilizando-se primers específicos (20 a 30 pb), seguido da digestão (clivagem) com endonucleases de restrição que relevam polimorfismos internos de um amplicon inicialmente identificado como sendo não-polimórfico em análises convencionais via PCR. As principais vantagens dos marcadores CAPS são a codominância e a alta reprodutibilidade e a principais desvantagens são a necessidade de conhecimento prévio de sequência de DNA para a construção dos primers e para a escolha das endonucleases de restrição (Faleiro, 2007).

Os microssatélites são conjuntos de sequências (geralmente de dois a seis nucleotídeos de comprimento) originadas por arranjos de repetições em tandem. O polimorfismo desses marcadores caracteriza-se pela variação do número dos elementos repetidos presentes na região. Essa variação no número de elementos repetidos ocorre, geralmente, devido aos erros da DNA polimerase durante o processo de replicação e reparo da molécula de DNA (Studart, 2001). O emprego de primers específicos flanqueando o segmento variável do microssatélite permite a sua amplificação e detecção dos polimorfimos, gerando amplicons de tamanhos diferentes. As principais vantagens dos marcadores microssatélites são a codominância, alta reprodutibilidade dos resultados e o elevado nível de polimorfismos devido à sua alta frequência de mutação e abundância na maioria dos genomas vegetais (Morgante et al., 1993; Milach, 1998; Matioli, 2001).

SNPs (Single Nucleotide Polymorphisms) são marcadores moleculares de DNA utilizados para identificar mutações/polimorfismos de base individual (Ansari et al., 2015). Com a crescente disponibilidade de bancos de dados de sequências, principalmente de ESTs (Expressed Sequence Tags), tem cada vez mais aumentado o ritmo de desenvolvimento e utilização de 
marcadores SNPs. O desenvolvimento de marcadores do tipo SNPs necessita do aporte de informações de sequenciamento do DNA para o desenho de primers. As variações do tipo SNP são caracterizadas por substituições ou deleções/inserções (coletivamente chamadas de Indels) de um único nucleotídeo. Estas classes de mutações são as formas de variação mais frequentemente encontradas nos diferentes genomas vegetais. As vantagens atribuídas aos SNPs para estudos genéticos são evidenciadas pela sua enorme aplicação em algumas espécies vegetais tais como Arabidopsis (Schmid et al., 2003), Zea mays (Bhattramakki et al., 2002) e Eucalyptus (Grattapaglia et al., 2011).

A aplicação das tecnologias coletivamente denominadas como next-generation sequencing (NGS) tem propiciado enormes avanços na caracterização de genomas vegetais alavancando os sistemas de genotipagem em larga escala disponíveis para os programas de melhoramento. Uma das estratégias derivadas dos sistemas NGS é a chamada genotipagem via sequenciamento genotyping-by-sequencing (GBS) que permite ampliar de maneira significativa a descoberta de marcadores moleculares (especialmente SNPs e Indels) ligados com características de interesse agronômico. A estratégia de GBS envolve a digestão do DNA genômico da espécie vegetal de interesse com enzimas de restrição (otimizadas para cada espécie) seguida de uma reação de ligação com adaptadores do tipo barcode que são empregados como moldes para ensaios de PCR e posterior sequenciamento do conjunto do DNA genômico amplificado. Esses barcordes permitem rastrear as sequências geradas de cada amostra (Craig et al., 2008). Os dados gerados pela estratégia GBS são posteriormente processados e analisados em plataformas de bioinformática. Várias plataformas NGS, como a Roche 454 FLX Titanium (Thudi et al., 2012), a Illumina MiSeq e HiSeq 2500 (Bentlley et al., 2008), Hiseq 3000 (Boland et al., 2013) e a Ion Torrent PGM (Rothberg et al., 2011) foram utilizadas (Deschamps et al., 2012; Quail et al., 2012) (Tabela 1). 
Tabela 1. Comparação das tecnologias e plataformas de next-generation sequencing.

\begin{tabular}{lcc} 
Plataforma de sequenciamento & Read Length (bp) & Reads per Run \\
\hline Roche 454 FLX Titanium & $\sim 800$ & $\sim 1$ milhão \\
Illumina Miseq & $2 \times 250^{\mathrm{a}}$ & $\sim 1$ milhão \\
Illumina Hiseq 2500 & $2 \times 100^{\mathrm{a}}$ & $\sim 3.0$ milhões \\
Ion Torrent PGM & 100 & $\sim 1$ milhão \\
Illumina Hiseq 3000 & $2 \times 150^{\mathrm{a}}$ & $\sim 2.5$ bilhões \\
\hline
\end{tabular}

${ }^{\mathrm{a}}$ Paired-end read sequencing

Os avanços nas metodologias de NGS têm propiciado uma redução considerável nos custos de sequenciamento de DNA (Elshire $\boldsymbol{e t}$ al., 2011). Esse sistema de última geração pode produzir centenas de milhões a centenas de bilhões de sequências simultaneamente, permitindo o desenvolvimento de marcadores em escala industrial. Os principais aspectos positivos deste sistema incluem: baixo custo, demanda por uma menor quantidade de DNA purificado, seleção do tamanho dos fragmentos, um número menor de etapas de PCR e purificação, não apresentam limites de sequência de referência, contam com código de barras eficiente e fácil para ampliação (Davey et al., 2011). Esse método está se tornando cada vez mais importante como uma ferramenta eficaz na seleção assistida em uma variedade de espécies de plantas (Elshire $\boldsymbol{e}$ al., 2011). A construção de bibliotecas de GBS é baseada na redução da complexidade do genoma com enzimas de restrição (Elshire et al., 2011). Essa abordagem é simples, rápida, extremamente específica, altamente reproduzível, podendo chegar a importantes regiões do genoma que são inacessíveis a outras abordagens de captura de sequência. A escolha de enzimas de restrição apropriadas pode evitar regiões repetidas do genoma e regiões com um número menor de cópias 
podem ser alvo com uma eficiência duas a três vezes maior (Gore et al., 2009), o que minimiza problemas de alinhamentos computacionais em espécies com níveis elevados de diversidade genética.

Devido a esse conjunto de características, a estratégia GBS é empregada em um variado grupo de estudos genéticos, incluindo os chamados genome-wide association studies (GWAS), diversidade genômica, desenvolvimento de marcadores moleculares, identificação de regiões genômicas contendo genes candidatos e características quantitativas (QTLs) de interesse (Deschamps et al., 2012; He et al., 2014). Esse conjunto de informações pode ser convertido em marcadores de interesse para sistemas aplicados de seleção de indivíduos superiores, combinando múltiplas características de interesse.

Em alface, avanços significativos estão sendo feitos utilizando a estratégia GBS. O desenvolvimento de mapas genéticos extremamente densos (i.e. com um número elevado de marcadores) tem permitido a localização genômica/isolamento de genes e o uso de diversos marcadores moleculares em programas de melhoramento com seleção assistida (Truco et al., 2013). A Universidade da Califórnia, em Davis, é a instituição com as maiores e mais relevantes contribuições no desenvolvimento de marcadores derivados de NGS em alface e espécies selvagens (silvestres) geneticamente relacionadas (Stoffel et al., 2012; Atkinson et al., 2013; Truco et al., 2013).

\section{RESISTÊNCIA DE PLANTAS A DOENÇAS}

A interação planta-patógeno envolve longos processos co-evolucionários que podem resultar no estabelecimento, por parte da planta hospedeira, de mecanismos de percepção dos agentes patogênicos e de ativação de sinais que podem ser convertidos em respostas de defesa específicas (ou não). Enfrentando a pressão seletiva imposta pelos patógenos, as plantas 
desenvolveram mecanismos genéticos para defesa pós-invasão, cujos produtos gênicos detectam direta ou indiretamente os efetores específicos do patógeno e desencadeiam respostas eficazes de defesa (Michelmore et al., 2013). Essa indução de sinalização de defesa da planta via reconhecimento de efetores específicos do patógeno é feita por conjuntos variados de produtos gênicos condificados por genes referidos como genes R (= resistência). Numerosos genes de resistência (R) já foram caracterizados e estão sendo, muitos deles, eficientemente utilizados em programas de melhoramento genético vegetal (Gururani et al., 2012).

O emprego de cultivares resistentes é a alternativa mais conveniente quando comparada com outras medidas de controle. Os benefícios de usar fatores de resistência incluem a redução eficiente do crescimento e propagação do patógeno, a redução de danos para a planta hospedeira, redução de agrotóxicos e, sobretudo, a produção de alimentos mais saudáveis. Além disso, é uma tecnologia fácil de ser adotada, uma vez que já vem imbutida na semente. O controle eficiente e sustentável de uma gama de patógenos como bactérias, fungos, oomicetos, vírus, nematóides e insetos é uma exigência para todos os sistemas agrícolas (Gurunani et al., 2012).

O melhoramento genético com base em genes de resistência está sendo otimizado através da incorporação de técnicas moleculares e biotecnológicas. A genética de resistência a patógenos é intensamente estudada em muitas espécies vegetais (Michelmore $\boldsymbol{e t}$ al., 2013). Com base na herança, a resistência é frequentemente classificada como monogênica (dominante ou recessiva) ou poligênica. Altos níveis de resistência contra raças específicas de um patógeno são controlados por um ou poucos genes, muitas vezes de grandes efeitos fenotípicos e de alta penetrância que tendem a ser estáveis em diversas condições ambientais. Esse tipo de resistência refere-se à monogênica ou resistência de gene maior (que engloba grande parte dos genes $\mathrm{R}$ ) (Michelmore et al., 2013). Entretanto, nem toda resistência monogênica confere imunidade completa. Níveis parciais ou intermediários na resistência são também observados em distintos 
patossistemas. Algumas vezes os genes R se mostram sensíveis às condições ambientais (Zhu $\boldsymbol{e t}$ al., 2010). A resistência de caráter poligênico é determinada por genes menores $(=$ de reduzido efeito fenotípico) múltiplos genes ou loci de características quantitativas, resultando em diferentes níveis de completa e incompleta resistência (Michelmore et al., 2013).

O desenvolvimento de novas abordagens para a proteção genética das culturas contra fitopatógenos demanda contínuos avanços no entendimento dos mecanismos moleculares que regulam os níveis de resistência da planta. Segundo Jones \& Dangl (2006), as ferramentas moleculares e genômicas têm possibilitado dissecar as principais estratégias e mecanismos empregados pelo chamado "sistema imunológico vegetal", a saber: PAMP (padrões moleculares associados a agentes patogênicos)-triggered immunity (PTI) e o effector-triggered immunity (ETI).

\section{RESISTÊNCIA BASAL E RESISTÊNCIA MEDIADA POR GENES R}

As plantas possuem dois tipos gerais de resistência a doenças: a defesa basal e a defesa mediada por genes R. A defesa basal, constituída por resistência do tipo 'não hospedeira' e 'hospedeira', representa a primeira linha de defesa contra a infecção por uma ampla gama de patógenos. A defesa basal envolve interações entre receptores de reconhecimento padrão (pattern recognition receptors - PRRs), como por exemplo, receptor-like kinases (RLKs) e o receptorlike proteins (RLPs). Esses se localizam na matriz extracelular ou na membrana plasmática (Jones \& Dangl, 2006; Dangl et al., 2013), e possuem a capacidade de reconhecimento dos PAMPs.

Geralmente, a resistência 'hospedeira' é especifica de uma cultivar ou de um acesso, enquanto a resistência 'não hospedeira' se manifesta contra uma ampla gama de potenciais agentes patogênicos em todos os membros de uma dada espécie de planta (Heath, 2000). 
Elicitores de defesa basal podem ser derivados da degradação da parede celular da planta hospedeira (que são liberados pela atividade hidrolítica das enzimas secretadas por patógenos invasores), mas também identificam características comuns dos diferentes grupos de patógenos, referidos como os PAMPs (Nürnberger et al., 2004).

Os PAMPs representam uma gama variável de moléculas contendo epítopos microbianos primordiais na sobrevivência ou aptidão de um dado grupo de patógenos, como, por exemplo, lipopolissacarídeos, quitinas, $\beta$-glucanos, peptidoglicanos, fator $\mathrm{Tu}$ de alongamento bacteriano, flagelina e ergosterol (Schwessinger et al., 2008). O termo padrões moleculares associados a micro-organismos (MAMPs) também pode ser empregado, visto que essas moléculas podem também ocorrer em microorganismos não patogênicos (Jones \& Dangl, 2006; Boller \& Felix, 2009). Essas interações promovem a PAMP-triggered immunity (PTI), que compreende a ativação de uma MAP (que é uma proteína associada com a mitogênese ou com capacidade de iniciar o processo de divisão celular), cascatas de proteínas quinases (enzimas que catalização a transferência de grupos fosfatos) e ativação de fatores de transcrição WRKY (TF). Essas alterações fisiológicas e bioquímicas impedem a colonização do patógeno e conferem um espectro de resistência efetivo contra a maioria dos patógenos em potencial. O PTI também inclui mudanças no fluxo de íons em todo o plasmalema, rápida produção de espécies ativas de oxigênio e indução de genes de defesa (Michelmore $\boldsymbol{e t}$ al., 2013).

Quando os patógenos conseguem ter sucesso na superação do PTI, uma segunda linha de defesa do sistema 'imunológico' vegetal pode evoluir e se manifestar: a chamada ETI (effectortriggered immunity). Genes de avirulência do patógeno evoluem de acordo com a espécie, a raça, formae especiales, os patotipos ou mesmo de acordo com efetores de avirulência de estipes que, após a secreção e translocação dentro da célula hospedeira, interferem ou desativam a sinalização da PTI, tornando as plantas suscetíveis ao patógeno, resultando da suscetibilidade do tipo 
effector-triggered susceptibility (ETS) (Gohre \& Robatzek, 2008). Desta forma, diferem-se dos PAMPs, pois atingem especificamente os mecanismos de defesa do hospedeiro. Dentro da ETI, encontra-se o modelo gene-a-gene e o modelo de Guarda.

Fitopatógenos produzem certas moléculas chamadas "efetores", que são codificadas pelos genes da avirulência (Avr) do patógeno. Os produtos dos genes de avirulência são liberados diretamente nas células da planta durante a fase inicial da infecção. Esses efetores podem alterar o estado fisiológico da planta hospedeira, a fim de beneficiar a colonização do patógeno ou serem utilizados para inteferir negativamente ou mesmo desativar as respostas de defesas das plantas (Hammond-Kosack et al., 2007). No entanto, as plantas têm desenvolvido uma forma adicional de imunidade que é baseada na percepção desses efetores por proteínas de resistência do hospedeiro codificadas pelos genes R (Nimchuk et al., 2003).

Os genes $\mathrm{R}$ são altamente polimórficos e possuem distintas especificidades de reconhecimento dos diferentes patógenos e variantes de patógenos. Normalmente, os genes $\mathrm{R}$ ocorrem como parte de uma família gênica em agrupamentos físicos (= clusters) que evoluíram via eventos de duplicação e recombinação. Em geral, cada gene $\mathrm{R}$ confere resistência a um patógeno específico. A forma de atuação deste mecanismo de defesa se adequa dentro do modelo clássico de gene-a-gene proposto por Flor (1971). Neste modelo, o gene R funciona como um receptor que é ativado ao receber um sinal externo, induzindo e/ou ativando uma cascata de sinais que são traduzidos para que se obtenha uma resposta de defesa. Essa resposta pode ser local, havendo uma reação local de hipersensibilidade (HR) na qual ocorre a morte programada de células no sítio inicial da infecção ou pode se apresentar como uma resposta sistêmica (Flor, 1971).

Um mecanismo associado de maneira consistente com o 'disparo' de reações de hipersensibilidade é a geração de intermediários reativos de oxigênio (Reactive Oxygen 
Intermediates) (ROIs) e de espécies ativas de oxigênio (EAOs), que envolvem a produção/liberação de superóxido $\left(\mathrm{O}_{2}\right)$ e o peróxido de hidrogênio $\left(\mathrm{H}_{2} \mathrm{O}_{2}\right)$. Esses eventos em associação com a produção coordenada de óxido nítrico (NO) são coletivamente denominados de 'explosão oxidativa' celular (Grant \& Loake, 2000). Essas alterações bioquímicas desempenham um papel crucial na ativação dos mecanismos de resistência a doenças em plantas. A explosão oxidativa associada com a HR é parte de um complexo sistema integrado de sinalização que envolve também a participação do ácido salicílico (AS) e alterações nos níveis de $\mathrm{Ca}^{+}$citosólico para desencadear mecanismos de defesa (Resende et al., 2003). Ocorre também no processo um acúmulo de fito-hormônios, especialmente o ácido jasmônico e o etileno. Modificações estruturais envolvem o espessamento da parede celular, produção de fenóis, ação de lipoxigenases, formação de fitoalexinas e indução da expressão de proteínas PR (Pathogenesis-related proteins) (Hammond-Kosak \& Parker, 2003). Esses eventos podem desencadear, posteriormente, uma resposta generalizada e de longa duração, prolongando-a de forma sistêmica e atuando mesmo longe do sítio de infecção (= Resistência Sistêmica Adquirida).

Um exemplo de HR em total conformidade com a hipótese gene-a-gene é fornecida por uma das mais caracterizadas interações planta-patógeno, entre a alface e o agente patogênico Bremia lactucae Regel, causando a doença denominada míldio da alface. Mais de 25 Dm (Downy mildew resistance) genes controlando resistência a $B$. lactucae foram identificados, sendo que a maioria deles apresenta caráter dominante (Crute \& Johnson, 1976; Farrara et al., 1987; Ilott et al., 1987; Michelmore et al., 2009).

O outro modelo para ação dos genes de defesa vegetal denomina-se como "modelo guarda" (Holt III et al., 2003). De acordo com essa teoria, a proteína R interage, ou "guarda", uma segunda proteína denominada "guardee", que é alvo da proteína Avr do patógeno invasor. Neste modelo, a ocorrência de interações envolvendo a proteína "guardee" serve como sinal para ativar 
a resistência mediada por genes $\mathrm{R}$ (Marathe \& Dinesh-Kumar, 2003). Por exemplo, em Arabidopsis thaliana, a proteína RPM1, codificada por um gene de resistência a Pseudomonas syringae pv. tomato, não se relaciona diretamente com a sua proteína Avr correspondente (avrRPM1). Nessa situação, ocorre a indução da proteína RIM4, a qual interage com a avrRPM1. Essa interação sinaliza para RPM1 que, por sua vez, desencadeia uma resposta de hipersensibilidade (HR) (Mackey et al., 2002). Da mesma maneira, o gene $C f-2$ de tomate que condiciona resistência ao fungo Cladosporium fulvum (que expressa Avr2) também necessita da expressão de um segundo gene (proteína $R C R 3$ ) (Krüger $\boldsymbol{e t}$ al., 2002), o que reforça o valor biológico desta hipótese (Pinto et al., 2010).

\section{MECANISMOS ESTRUTURAIS E FUNCIONAIS DE GENES DE}

\section{RESISTENCIA CARACTERIZADOS EM PLANTAS.}

Os genes de resistência caracterizados até o momento são classificados em grupos ou famílias gênicas que possuem regiões filogeneticamente conservadas, denominadas motivos (motifs) ou domínios (domains), os quais podem incluir proteínas ricas em leucina (Leucine-rich repeats - LRR), sítios de ligação a nucleotídeos (Nucleotide binding sites - NBS), estruturas complexas envolvendo a combinação de estruturas do tipo NBS-LRR ou ainda genes combinando domínios para localização em membranas (= transmembrane domains) e repetições ricas em leucina (TM-LRR) (Hammond-Kosack \& Jones, 1997).

Outros estudos têm identificado diferentes motivos/domínios relacionados aos mecanismos de resistência em plantas, incluindo repetições de pentatricopeptideo e peroxidases (Staskawicz et al., 1995; Liu et al., 2007). Em alguns genes os domínios NBS-LRR podem apresentar organizações estrutrais mais complexas aparecendo em associação com outros domínios como, por exemplo, TIR (Toll interleucine receptor)-NBS-LRR (sigla TNL) ou não TNL/coiled-coil- 
NBS-LRR (sigla CNL). Os alvos dos genes das classes TNL e CNL são especificamente proteínas efetoras patogênicas no interior da célula hospedeira, que caracteriza as respostas do tipo ETI - effector-triggered immunity.

Da mesma forma, os TM-LRRs podem ser divididos em duas classes: receptores do tipo quinase (Receptor-like kinases - RLKs) ou proteínas do tipo receptoras (Receptor-like proteinRLPs). RLPs e RLKs são receptores de reconhecimento padrão (PRRs) que interferem na associação dos padrões moleculares associados de microorganismos (PAMPs/MAMPs), desencadeando o sistema imunológico vegetal para permitir o reconhecimento de uma ampla gama de agentes patogênicos (Sekhwal et al., 2015).

Família NBS-LRR: Nucleotide Binding Site - Leucine Rich Repeats: Os genes da classe NBS-LRR consistem, estruturamente, em uma extremidade N-terminal variável, uma ligação conservada de nucleotídeos de domínio interno (NB)-ARC, e um carboxi-terminal altamente polimórfico com múltiplas repetições ricas em leucina (LRRs) (Sekhwal et al., 2015). Os NBSLRR podem ser classificados em dois grandes grupos: o TNL e o CNL, baseados na presença ou ausência de receptor TOLL/interleucina-1 (TIR), que mostram homologia com domínios de sinalização de Drosofila (Toll) e um interleucina (IL) basal de mamíferos ou coiled coil (CC) (cauda espiralada) no N-Terminal. NBS-LRR é a família mais conhecida, pois todos os os genes integrantes desta família estão relacionados de alguma forma a resistência de plantas a fatores bióticos. Os genes que codificam NBS-LRR estão, normalmente, localizados em agrupamentos físicos (clusters) nos genomas vegetais como resultado de eventos de duplicação de segmentos de linhagens específicas, seguidos por eventos de rearranjos locais (Zhang et al., 2014). A expansão de clusters individuais ocorre através da duplicação em tandem, originados de crossing-overs desiguais (Richly et al., 2002; Meyers et al., 2003; Zhou $\boldsymbol{e t}$ al., 2004). A complexidade desses clusters também é afetada pela perda de genes ou de função de genes e também de ganhos de 
função de genes através da seleção natural, em um processo referido como "nascimento-e-morte" (Michelmore \& Meyers 1998; Mondragon-Palomino \& Gaut 2005; Guo et al., 2011). Esses processos genéticos e evolutivos têm resultado em complexos e variáveis clusters no genoma, conferindo diversidade alélica e geração de novos fatores resistência contra múltiplas doenças.

Família RLK e RLP (Receptor Like Kinase - RLK e Receptor Like Protein - RLP): Essas duas classes de proteínas são estruturalmente semelhantes, apresentando um peptídeo de sinal (SP) no início do N-terminal e domínios extracelulares de percepção do padrão microbiano através das repetições ricas em leucina. Apresentam também um domínio de hélice transmembranar (TrD) que permitem a ancoragem das proteínas na membrana plasmática. As RLPs diferem de RLKs pela falta de um domínio quinase intracelular. As RLPS e RLKs são consideradas PRRs que reconhecem elicitores, tais como lipídeos, proteínas, ácidos nucléicos e carboidratos (Sekhwal et al., 2015).

Família Receptor Like Kinase - RLK: Os genes da família RLK estão envolvidos na defesa e também no desenvolvimento da planta. As protéinas dessa família podem ser divididas em duas classes principais. A primeira consiste em proteínas quinases envolvidas na interação plantapatógeno e respostas de defesa. Por exemplo, o gene Xa21, no arroz, está envolvido na resistência a uma doença bacteriana causada por Xanthomonas oryzae (Xoo) e o gene $F l s 2$ na percepção da flagelina em Arabidopsis thaliana. $\mathrm{Na}$ segunda, as proteínas estão envolvidas no desenvolvimento celular e no crescimento, assim como em Arabidopsis, nos genes de abscisão de órgãos florais (Jin et al., 2000), no desenvolvimento do meristema (clavatal) (Clark et al., 1997) e na regulação do crescimento celular (Bril) (Li \& Chory, 1997). As proteínas quinases alteram estrutras e funções de proteínas-alvo, fosforilando grupos específicos de serina e treonina. Por sua vez a quinase receptora de histidina (RHKs) pode fosforilar resíduos de 
histidina, por exemplo, em produtos gênicos associdados com a produção de etileno (ETR1) (Bleecker et al., 2000) e citoquininas (CRE1) (Inoue et al., 2001).

Familia de genes do tipo Receptor Like Protein - RLP: Os genes desta família codificam proteínas que possuem um domínio LRR extracelular no N-Terminal ancorado à célula com pequenos domínios transmembranares. O gene $C f-9$ foi o primeiro gene identificado nessa família, conferindo resistência à mancha foliar de $C$. fulvum no tomateiro. De fato, vários genes da família $C f$ pertencem à família RLP (Dixon $\boldsymbol{e t}$ al., 1996, 1998). Nem todos os RLPs estão envolvidos na resistência a doenças, alguns desempenham um papel de desenvolvimento da planta, como por exemplo, o gene clavata2 $(C l v 2)$ e o gene $(T M M)$ que estão envolvidos no desenvolvimento de meristema e na regulação estomática em Arabidopsis, respectivamente.

\section{OUTRAS CLASSES DE GENES DE RESISTÊNCIA}

O sistema de defesa vegetal é iniciado quando receptores extracelulares transmitem sinais para elementos intracelulares. Para detectar os sinais de organismos invasores, as células vegetais possuem sistemas de receptores TM (transmembranares) que facilitam a comunicação entre ambientes intra e extracelulares. Entretanto, vários receptores TM relatados não contêm domínios completos como observado em NBS-LRR e RLPs ou RLKs. Assim, o termo "outros genes" é utilizado para classificar esses genes peculiares.

Família serina treonina quinase citoplasmática desprovida de domínio LRR (STK): Esta família codifica proteínas que não contêm domínios NBS-LRR. Caracteriza-se pela presença de uma quinase que fosforila resíduos de serina e treonina (Tang et al., 1996). Um exemplo clássico é o gene Pto, que, em conjunto com o gene $\operatorname{Prf}$, confere resistência a algumas estipes de Pseudomonas syringae pv. tomato em tomate via reação de hipersensibilidade e morte celular programada (Frederick et al., 1998). Essa família gênica também já foi caracterizada em $A$. 
thaliana, Phaseolus vulgaris (Nomura et al., 2005) e Musa acuminata (Peraza-Echeverria et al., 2007).

Família coiled coil ancorado à membrana: Os genes de resistência dessa família contêm um domínio transmembranar, ancorado a um domínio coiled-coil. O principal representante dessa família é o gene $R P W 8$ em Arabidopsis, que codifica uma redutase localizada na membrana, com uma estrutura helicoidal (Xiao et al., 2001). Esse gene ativa a produção de ácido salicílico como estratégia de defesa e promove o acúmulo local de $\mathrm{H}_{2} \mathrm{O}_{2}$, provavelmente para restringir o crescimento do haustório e, ao mesmo tempo, reduzir o dano oxidativo às células hospedeiras, conferindo um amplo espectro de resistência (Xiao et al., 2003).

\section{GENES ANALÓgOS DE RESISTÊNCIA (RGAs): ESTRUTURA, FUNÇÃO \&}

\section{DIVERSIDADE}

Os genes análogos de resistência (resistance gene analogs-RGAs) são genes, pseudogenes, ou regiões genômicas que apresentam características estruturais similares e/ou sequências com identidade com os diferentes domínios conservados presentes nos genes de resistência caracterizados em plantas. Esta conservação estrutural apresenta um enorme interesse do ponto de vista genético, uma vez que sugerem que elas representem sítios de relevância biológica na expressão fenotípica dos genes de resistência (Bent, 1996). Com base nessa conservação filogenética um novo sistema de marcadores foi concebido para análises genéticas. Nesse sistema, um conjunto de primers degenerados foi desenhado com o objetivo de amplificar (usando técnicas simplificadas de PCR heterólogo) regiões análogas a genes de resistência (RGAs) que se encontram conservadas em várias espécies vegetais (Leister et al., 1996; Kanazin et al., 1996; Yu et al., 1996). 
Em diversos trabalhos, observou-se que os marcadores do tipo RGAs co-localizam com genes de resistência ou os amplicons produzidos podem até mesmo representar segmentos dentro de genes de resistência funcionais (Hammond-Kosack \& Jones, 1997). Neste sentido, o sistema de marcadores RGAs constitue uma ferramenta útil para a construção de mapas genéticos e em seleção assistida dentro de programas de melhoramento genético vegetal. A possibilidade de gerar um grande número de polimorfismos entre diferentes acessos de uma mesma espécie ou gênero também pode permitir o uso dos marcadores RGAs em sistemas de caracterização genética de acessos (fingerprinting) e cultivares (Hammond-Kosack \& Jones, 1997).

\section{ANÁLISES DE GENES R CANDIDATOS E DE RGAs EM ALFACE}

Como mencionado, nos genomas vegetais, os genes de resistência são frequentemente encontrados formando agrupamentos físicos (clusters) em distintas regiões cromossomais (Michelmore \& Meyers 1998). Um clássico exemplo do agrupamento físico de genes de resistência em alface é ilustrado pelo grupo de ligação LG 2 que abriga pelo menos nove $D m$ (Downy mildew resistance) genes conhecidos, incluindo o já clonado Dm3 (Meyers et al., 1998), que pertence à família NBS-LRR (Shenet et al., 2002).

Análises de ESTs de alface identificaram mais de 700 genes R candidatos que apresentaram sequências e/ou estruturas similares as identificadas em genes de resistência já caracterizados em plantas (McHale et al., 2008). Estes genes podem ser classificados em quatro grandes grupos: (1) genes candidatos para resistência (RGCs); (2) Genes de sinalização (signaling pathway genes);

(3) Genes associados com respostas gerais de defesa (defense response associated genes) e (4) fatores de susceptibilidade (susceptibility factors) (McHale et al., 2009). RGCs em alface foram categorizados em 20 famílias baseados nas similaridades das sequências. RGC2 é uma grande família gênica que inclui mais de 40 membros conferindo resistência a patógenos 
economicamente importantes e se localizam no cromossomo 2 (Kuang et al., 2004, 2008; Christopoulou et al., 2015a,b).

\section{ABORDAGENS DE BIOINFORMÁTICA PARA IDENTIFICAÇÃO E CARACTERIZAÇÃO DE GENES DE RESISTÊNCIA E RGAs EM GENOMAS VEGETAIS}

$\mathrm{O}$ número de genes $\mathrm{R}$ varia muito entre espécies, por exemplo, 54 foram anotados em Carica papaya (Porter et al., 2009), $150 \mathrm{em}$ Arabidopsis thaliana (Meyers et al., 2003), $571 \mathrm{em}$ Medicago truncatula (Shao et al., 2014), 465 em Glycine max (Shao et al., 2014), 402 em Populus trichocarpa (Kohler et al., 2008), 535 em Oryza sativa (Zhou et al., 2004), 1015 em Malus domestica (Arya et al., 2014) e 1134 em Lactuca sativa cv.'Salinas' (Christopoulou et al., 2015b). A prevalência dos diferentes grupos também pode variar consideravelmente, por exemplo, o grupo TNL apresenta ampla ocorrência em Eudicots (Primula hortensis), mas estão ausentes no genoma de monocotiledôneas.

Mais recentemente, os genes de resistência e RGAs foram identificados a partir de genomas sequenciados utilizando ferramentas de bioinformática. Nos últimos 15 anos, mais de 50 genomas de plantas foram sequenciados e montados e suas sequências estão sendo depositadas e liberadas em bancos de dados públicos como o Phytozome (Goodstein et al., 2012; Nordberg et al., 2014) e o EnsemblPlants FTP servers (Bolser et al., 2015). Avanços no sequenciamento de próxima geração são umas das abordagens mais importantes da pesquisa biológica moderna.

Vários métodos de bioinformática foram utilizados para identificar genes de resistência e RGAs e predizer suas funções, incluindo alinhamento de sequências, pesquisa pelo BLAST, análise filogenética, análise de domínio e motivos, utilizando diversas aplicações, como o Hidden Markov Model (HMM) (Yoon et al., 2009), SMART (http://smart.embl-heidelberg.de/) (Schultz 
et al., 2000), o Prosite (http://prosite.expasy.org/), o pfam (http://pfam.xfam.org/) e o InterProScan5 (http://www.ebi.ac.uk/Tools/pfa/iprscan5/).

A identificação e a caracterização de genes de resistência e RGAs segue, geralmente, uma sequência de procedimentos padrões. O primeiro passo envolve a obtenção das sequências obtidas dos marcadores (amplicons) obtidos em ensaios de PCR com primers degenerados, usando como molde o DNA genômico extraído de acessos contrastantes de uma dada espécie vegetal. Na segunda etapa, as sequências obtidas são comparadas com as sequências disponíveis em plataformas tais como GenBank e PRGdb usando o algoritmo BLAST. Essa etapa visa confirmar e identificar a presença de potenciais genes de resistência candidatos. Na terceira etapa, ferramentas de software são empregadas para identificar os diferentes domínios, motivos conservados e produzir alinhamentos. No último passo, é realizada uma classificação dos genes $\mathrm{R}$ candidatos de acordo com seu domínio e motivos ou a suas combinações.

Até o momento, não há ferramentas de bioinformática padronizadas e critérios consistentes que foram empregados em estudos individuais. Além disso, ferramentas de software individuais têm suas próprias vantagens e limitações para identificar os diferentes domínios dos genes R. Um pacote de software mais abrangente, capaz de integrar ferramentas individuais de análise facilitaria o processamento, a padronização de organização de dados, permitindo uma consistente identificação dos genes $\mathrm{R}$ em análises comparativas entre as espécies e acessos dentro de espécies (Sekhwal et al., 2015).

\section{MAPAS DE LIGAÇÃO E LOCALIZAÇÃO DE QTLS}

Marcadores apresentando frequência de recombinação abaixo de 50\% são descritos como sendo ligados (linked) e acima desse valor são considerados como sendo não-ligados (unlinked). A indicação de ausência de ligação significa que os marcadores podem estar localizados em 
braços distintos de um mesmo cromossomo ou em cromossomos diferentes. Funções de mapeamento são usadas para converter frações de recombinação em unidades do mapa chamada de centiMorgans (cM). Mapas de ligação são construídos a partir da análise de diversos marcadores (por exemplo, fenotípicos, bioquímicos e moleculares) em populações segregantes. As três etapas principais na construção de mapas de ligação são: (a) produção de uma população segregante para mapeamento, (b) identificação de polimorfismos entre os parentais e (c) análise do padrão de segregação e de ligação entre marcadores polimórficos e fenótipos (Collard $\boldsymbol{e t}$ al., 2005).

Populações de mapeamento: A construção de um mapa de ligação requer uma população segregante obtida do cruzamento controlado entre parentais divergentes para uma ou mais características de interesse. O tamanho da população recomendado para trabalhos de mapeamento genético varia entre 50 a 250 ou mais indivíduos (Mohan et al., 1997). Populações com um número mais elevado de indivíduos são necessárias para o mapeamento de 'alta resolução'. Diferentes populações podem ser utilizadas para mapeamento dentro de uma determinada espécie de planta, todavia, cada tipo de população possui vantagens e limitações (McCouch \& Doerge, 1995). Os tipos mais simples de populações de mapeamento para espécies autógamas são as populações $F_{2}$, geradas a partir da autofecundação de uma planta híbrida $F_{1}$, e populações de retrocruzamentos, derivadas do cruzamento de um indivíduo da geração $\mathrm{F}_{1}$ com um dos parentais contrastantes. As principais vantagens destas populações são a facilidade de geração e exigência de apenas um curto período de tempo para produzi-las. Além disso, na população $\mathrm{F}_{2}$, os gametas de cada indivíduo são informativos, fazendo com que a quantidade de informação disponível seja o dobro daquela disponível nas populações derivadas de retrocruzamentos. Por esses motivos e somado ao fato da população $\mathrm{F}_{2}$ possuir todas as possíveis combinações dos alelos parentais (AA, 
Aa \& aa), essa população é amplamente utilizada para mapeamento de ligação em plantas (Guimarães et al., 2006).

$\mathrm{O}$ avanço nos níveis de endogamia a partir de plantas individuais da geração $\mathrm{F}_{2}$ via ciclos sistemáticos de autofecundação permite a construção de outro tipo de população de mapeamento, denominadas de RILs (recombinant inbred lines). As RILs consistem em uma série de linhagens $\mathrm{F}_{6}$ ou $\mathrm{F}_{7}$ (portanto, com níveis elevados de homozigose) cada uma contendo uma combinação única de segmentos cromossômicos dos parentais originais. O tempo necessário para a obtenção das RILs (entre seis a sete gerações) é maior desvantagem dessa estratégia quando comparada com o uso da geração $\mathrm{F}_{2}$. As linhagens duplo-haplóides (DH), por sua vez, podem ser reproduzidas pela duplicação natural ou pela indução da duplicação do conjunto cromossômico em células haplóides ou pela produção artificial via cultivo de células de pólen ou de células-ovo. A produção de populações DH só é possível em espécies que são passíveis de cultura de tecidos (por exemplo: pimentão, cenoura, arroz, cevada e trigo). A maior vantagem das populações DH e RILs é que elas produzem linhas homozigotas que podem ser multiplicadas e reproduzidas sem ocorrência de alteração genética. Essas populações representam recursos genéticos permanentes para o mapeamento de genes individuais e QTLs (Paterson, 1996). A pureza genética das populações DH e RILs permite a realização de ensaios comparativos em diferentes locais e anos.

Padrões de segregação e razões mendelianas de acordo com o teste do qui-quadrado $\left(\chi^{2}\right)$ : $O$ qui-quadrado é um teste estatístico empregado para avaliar quantitativamente se o conjunto de dados obtidos em um experimento difere daqueles obtidos ao acaso. Este teste estima se a distribuição de uma determinada classe fenotípica e/ou genotípica se adequa a uma hipótese formulada para explicar um dado fenômeno genético. Esse teste estima um grau de 'certeza' de que os valores observados estão de acordo com a hipótese formulada para uma dada distribuição fenotípica e/ou genotípica. A formula de $\chi^{2}=\Sigma\left[(\mathrm{o}-\mathrm{e})^{2} / \mathrm{e}\right]$ onde: $\mathrm{o}=$ frequência observada de uma 
classe fenotípica e/ou genotípica; $\mathrm{e}=$ frequência esperada de uma classe fenotípica/genotípica; $\Sigma$ = somatório dos valores da expressão. É proposta uma hipótese nula $\mathrm{H}_{0}$, onde as frequências observadas não são diferentes das frequências esperadas. Comparando o valor esperado com o observado para cada fenótipo obtém-se o desvio. Verifica-se se os desvios são significativos ou não, baseados na probabilidade de ocorrência do evento. Se os desvios não são significativos, conclui-se que eles são devidos ao acaso, aceitando-se a hipótese formulada. Por outro lado, se os desvios são significativos, a hipótese é rejeitada, havendo necessidade de se formular nova hipótese para explicar os resultados obtidos. É necessário nesse teste fazer a comparação de dois valores estatísticos denominados de $\chi^{2}$ calculado e $\chi^{2}$ tabelado. As frequências observadas são obtidas diretamente dos dados amostrais, enquanto as frequências esperadas são calculadas a partir da hipótese a ser testada $\left(\mathrm{H}_{0}\right)$. Assim, o $\chi^{2}$ calculado é obtido a partir dos dados experimentais, levando-se em consideração os valores observados e os esperados, tendo em vista a hipótese. Já o $\chi^{2}$ tabelado depende do número de graus de liberdade e do nível de significância adotado. A tomada de decisão é feita comparando-se os dois valores de $\chi^{2}$. Se $\chi^{2}$ calculado $\geq \chi^{2}$ tabelado: Rejeita-se $\mathrm{H}_{0}$. Por sua vez, se $\chi^{2}$ calculado $<\chi^{2}$ tabelado aceita-se $\mathrm{H}_{0}$, o que significa que o desvio observado nos dados experimentais pode ser atribuído exclusivamente ao acaso (Schuster \& Cruz, 2004; Ramalho et al., 2008).

Identificação de polimorfismos: A segunda etapa na construção de um mapa de ligação é identificar marcadores fenotípicos, bioquímicos ou de DNA que revelam diferenças entre os parentais (ou seja, revelam polimorfismos). Em geral, espécies de polinização cruzada (alógamas) possuem níveis mais elevados de polimorfismo de DNA em comparação com as espécies endogâmicas (autógamas) tais como a alface. O mapeamento de espécies endogâmicas geralmente requer a seleção de parentais que são geneticamente divergentes (= pouco 
relacionados). Na maioria dos casos, os parentais são selecionados com base no nível de diversidade genética (Collard et al., 2005).

Sistemas de marcadores moleculares de DNA: A escolha dos sistemas de marcadores de DNA a serem utilizados para o mapeamento depende da disponibilidade de marcadores caracterizados para uma determinada espécie ou grupo taxonômico relacionado. Uma vez que os marcadores polimórficos entre as linhagens parentais são identificados, a segregação destes marcadores pode ser monitorada na população de mapeamento ("genotipagem"). Dessa forma, o DNA deve ser extraído de cada indivíduo da população de mapeamento. Os caracteres mapeados devem distribuir-se de acordo com um padrão de segregação mendeliana. Este padrão pode ser verificado através do teste qui-quadrado. A segregação mendeliana não é observada quando os loci apresentam distorção de segregação, o que é, por exemplo, observado comumente em cruzamentos interespecíficos (Collard et al., 2005).

Análise de ligação (linkage) entre marcadores: A etapa final na construção de um mapa de ligação envolve a codificação de dados para cada marcador e para cada indivíduo da população. A análise de ligação pode ser realizada de forma manual para um conjunto pequeno marcadores, no entanto, não é viável analisar e determinar as ligações entre um grande número de marcadores. Desta forma, programas de bioinformática são comumente empregados para essa finalidade. A condução de análises de ligação em larga escala é feita utilizando aplicativos computacionais. Ausências de dados para algumas combinações indivíduos-marcadores (= missing data) também podem ser aceitas e incorporadas nas análises conduzidas nesses programas. A ligação entre os marcadores é normalmente calculada usando o odds ratio, ou seja, a proporção (ratio) de ligação versus a proporção de não ligação.

Grupos de ligação: Marcadores ligados são agrupados em grupos de ligação, que são definidos como grupos de genes (ou marcadores) cujos loci estão localizados em um mesmo 
segmento cromossomal ou em um mesmo cromossomo. Estatisticamente, um grupo de ligação pode ser definido como um conjunto de loci que são herdados conjuntamente (Liu, 1998). Um mapa genético é considerado como sendo saturado quando o número obtido de grupos de ligação é igual ao número haplóide de cromossomos de uma espécie (Paterson, 1996). Muito frequentemente, os marcadores polimórficos identificados não estão uniformemente distribuídos ao longo dos cromossomos, deixando áreas descobertas ou, de maneira oposta, formando densos agrupamentos (clusters) em algumas regiões (Paterson, 1996). Além da distribuição aleatória dos marcadores, a frequência de recombinação não é igual ao longo dos cromossomos. A acurácia na medição da distância genética e a determinação da ordem dos marcadores estão diretamente relacionadas com o número de indivíduos estudados nas populações de mapeamento. Preferencialmente, as populações de mapeamento devem consistir, no mínimo, em 50 indivíduos na construção de mapas de ligação (Young, 1996).

QTLs (Quantitative Trait Loci): As principais características de relevância agronômica apresentam herança do tipo multifatorial ou poligênica. Para estes caracteres, a variação entre indivíduos é resultante de múltiplos loci, da interação entre eles e dos efeitos ambientais envolvidos na determinação dos fenótipos (Ferreira \& Gattapaglia, 1998). Devido ao grande número de genes controlando tais características, os fenótipos resultantes seguem um padrão contínuo de variação. Essas características quantitativas ou loci gênicos (ou regiões genômicas) relacionados com seu controle recebem a designação de QTL (Quantitative Trait Loci). A análise desses loci associada ao uso de mapas genéticos, obtidos por marcadores moleculares possibilita identificar, quantificar e mapear o efeito dos QTLs (Tanksley et al., 1988). Muitos fatores contribuem na eficiência de identificação de QTLs: a herdabilidade da característica, o número de QTLs, a magnitude do seu efeito sobre a característica, interação genótipo $x$ ambiente, a análise de um grande número de indivíduos de diferentes gerações de populações segregantes, ensaios 
experimentais para mensuração do fenótipo de interesse, da frequência de recombinação entre o marcador e o QTL, tamanho do genoma e saturação do mapa (Tanksley, 1993; Young, 1996).

Mapeamento de QTLs (Quantitative trait loci): O mapeamento de QTLs baseia-se no princípio em que cada um dos genes responsáveis pela expressão fenotípica de um caráter poligênico e marcadores genéticos ou moleculares ligados a esses genes co-segregam (via recombinação cromossômica ou crossing-over) durante a meiose (reprodução sexual), permitindo assim sua análise nas progênies (Young, 1996). Genes e marcadores que estão fortemente ligados serão transmitidos dos parentais para a progênie com maior frequência do que aqueles genes e/ou marcadores que não estão ligados com um determinado fator quantitativo (Collard et al., 2005). A frequência de genótipos recombinantes é utilizada para calcular frações de recombinação, que são usadas para inferir a distância genética entre os marcadores e o caráter em estudo. Ao analisar a segregação dos marcadores, a ordem relativa e a distância entre os marcadores, pode-se determinar que, quanto menor frequência de recombinação entre dois marcadores, mais perto eles estão situados em um cromossomo. Inversamente, quanto maior a frequência de recombinação entre dois marcadores, mais distantes estão situados no cromossomo (Collard et al., 2005).

Ferramentas computacionais para análise de QTLs: O programa QTL Cartographer consiste em um conjunto de programas de mapeamento de QTLs a partir de um mapa de ligação genético estipulando valores de LOD Score (LOD) para cada região analisada do mapa (Basten et al., 2001). A caracterização do LOD está em função do número de marcadores avaliados e do comprimento do mapa de ligação. As estratégias de mapeamento via Single-Marker-Analysis, Mapeamento por Intervalo Simples (Simple Interval Mapping), Mapeamento por Intervalo Composto (Composite Interval Mapping) e o Mapeamento por Múltiplos Intervalos (Multiple Interval Mapping) (Tanksley, 1993; Kao et al., 1999) são as mais utilizadas em estudos de mapeamento de caracteres quantitativos. O Single-Marker-Analysis é o método mais simples para 
detecção de QTLs associado a marcadores individuais. Este método não requer um mapa de ligação completo e pode ser realizado através de testes estatísticos como teste $t$, analise de variância (ANOVA) e regressão linear simples. No entanto, quando a distância entre o marcador e o QTL for grande, menos provável será detectá-lo tendo em vista a possibilidade de recombinação entre o gene marcador e o QTL, dificultando a estimativa da magnitude do efeito do QTL (Lynch \&Walsh, 1998). Por sua vez, o Simple Interval Mapping utiliza mapas de ligação e intervalos de análise entre pares adjacentes de marcadores ligados ao longo dos cromossomos simultaneamente, por regressão linear ou estimativa de verossimilhança, para estimar a frequência de recombinantes e a magnitude do efeito do QTL entre dois marcadores ligados (Lander \& Botstein, 1989; Carneiro et al., 2002). O Composite Interval Mapping é o método mais preciso e eficaz, especialmente quando existem QTLs ligados, pois avalia os QTLs fora do intervalo em questão, por um modelo de regressão múltipla, evitando que toda variação devida a outros QTLs fora do intervalo sejam residuais, elevando a precisão das estimativas. A desvantagem deste método é que não se permite estimar os efeitos epistáticos (Jansen, 1993; Zeng, 1993, 1994; Carneiro et al., 2002). O Multiple Interval Mapping é um modelo desenvolvido posteriormente e que leva em consideração os efeitos de epistasia e de múltiplos QTLs, utilizando diversos intervalos de marcadores simultaneamente, para buscar, testar posições e verificar interações de vários QTLs (Kao et al., 1999).

\section{MAPAS GENÉTICOS E FERRAMENTAS GENÔMICAS DISPONÍVEIS PARA}

\section{Lactuca sativa}

Para o gênero Lactuca, diversos mapas foram relatados utilizando populações a partir de cruzamentos intraespecíficos e/ou interespecíficos (Kesseli et al., 1994; Witsenboer et al., 1997; Waycott et al., 1999; Johnson et al., 2000; Jeuken et al., 2001; Syed et al., 2006). Um mapa 
molecular de referência em alface foi construído utilizando RILs (Recombinant inbred lines) derivadas da população de mapeamento L. sativa cv. 'Salinas' $x$ L. serriola 'UC96US23' (Truco et al., 2007). Este mapa foi construído utilizando mais de 700 marcadores AFLP e SSR e, posteriormente, um mapa genético ultradenso foi gerado com aproximadamente 14.000 loci baseados em sequências transcritas por um chip de microarray (Michelmore et al., 2010; Stoffel et al., 2012; Truco et al., 2013). O chip contém sequências para detectar polimorfismos em aproximadamente 35.000 unigenes e, com isso, facilita a análise de alto rendimento, a massiva genotipagem e a análise de expressão de genes de alface (Stoffel $\boldsymbol{e t}$ al., 2012). Aproximadamente 45.000 genes modelos foram preditos em Scaffolds (Michelmore et al., 2010; Reynes-Chin Wo et al., 2012) que está atribuído ao mapa de referência utilizando a tecnologia genotyping-bysequencing (GBS) (Elshire et al., 2011). Sequências do genoma da alface foram liberadas publicamente em 2012. As mais completas e recentes informações sobre o projeto do genoma da alface, utilizando uma variedade de recursos genéticos e genômicos, estão disponíveis como uma parte do Compositae Genome Project (CGP), no website http://cgpdb.ucdavis.edu. Uma população de mapeamento entre o cruzamento de L. sativa 'Salinas 88 ' $x$ L. sativa 'La Brilhante' utilizando a metodologia GBS também desenvolveu mais de 1000 marcadores SNPs em alface e foram utilizados para a construção de um novo e articulado mapa de ligação (Truong $\boldsymbol{e t}$ al. 2012). Da mesma forma foi construído um mapa de referência por McHale et al. (2009) e Christopoulou et al. (2015a,b) contendo 36 loci associados a fenótipos de resistência e 20 QTLs para dez patógenos e um para insetos. Os fatores de resistência mapeados em alface foram para os seguintes patógenos/doenças: míldio (Downy mildew, causada por Bremia lactucae Regel), corky root (Sphingomonas suberifaciens, formely Rhizomonas suberifaciens), Lettuce Dieback, causada pelo complexo viral Tomato bushy stunt virus - TBSV e Lettuce necrotic stunt virus LNSV, outras viroses [mosaico (Lettuce mosaic virus-LMV) e Turnip mosaic virus - TuMv)], 
root downy mildew causado por Plasmopara lactucae-radicis (Stang. \& Gilbn), oídio (Golovinomyces cichoraceatum sensu stricto - formerly Erysiphe cichoracearum DC), big-vein (Mirafiori lettuce big-vein virus - MLBVV), antracnose (Microdochium panattonianum (Berl.), podridão de esclerotínia (Sclerotinia minor Jagger e S. sclerotiorum (Lib.) de Bary) mancha bacteriana (Xanthomonas campestris pv. vitians (Brown) Dye), murcha de verticílio (Verticillium dahliae Kleb) e murcha de fusário (F. oxysporum f. sp. lactucae) (Tabela 2).

Tabela 2. Lista de genes de resistência e QTLs (Quantitative trait loci) localizados nos diferentes grupos de ligação (Linkage Groups - LG) disponíveis nos mapas de ligação da alface (Lactuca sativa L.).

\begin{tabular}{|c|c|c|c|c|c|c|c|c|c|}
\hline Doença & LG1 & LG2 & LG3 & LG4 & LG5 & LG6 & LG7 & LG8 & LG9 \\
\hline Míldio (Downy mildew) & $D m 5 / 8$ & Dm1 & $D m 13$ & Dm4 & & & qDM7.1 & & qDMR9.1 \\
\hline Míldio (Downy mildew) & Dm10 & $D m 2$ & & $\operatorname{Dm} 7$ & & & qDMR7.1 & & qDMR9.2 \\
\hline Míldio (Downy mildew) & Dm17 & Dm3 & & Dm11 & & & & & qDMR9.3 \\
\hline Míldio (Downy mildew) & $D m 25$ & Dm6 & & $D m 24$ & & & & & \\
\hline Míldio (Downy mildew) & Dm36 & Dm14 & & Dm38 & & & & & \\
\hline Míldio (Downy mildew) & Dm37 & Dm15 & & Dm44 & & & & & \\
\hline Míldio (Downy mildew) & Dm43 & Dm16 & & $D m 48$ & & & & & \\
\hline Míldio (Downy mildew) & $D m 45$ & Dm18 & & Dm49 & & & & & \\
\hline Míldio (Downy mildew) & $R B Q 2$ & Dm50 & & qDM4.1 & & & & & \\
\hline Míldio (Downy mildew) & qDMR1.1 & qDMR2.2 & & & & & & & \\
\hline Míldio (Downy mildew) & & $q D M 2.1$ & & & & & & & \\
\hline Root aphid resistance & & $\boldsymbol{R} a$ & & & & & & & \\
\hline Corky root & & & Cor & & & & & & \\
\hline Lettuce mosaic virus & Mo-2 & & & $m o-1$ & & & & & \\
\hline Lettuce dieback & & Tvr1 & & & & & & & \\
\hline Murcha de verticílio & & & & & $q V R T$ & & & $q V R T$ & Vr1 \\
\hline Turnip mosaic virus & $T u$ & & & & & & & & \\
\hline Root downy mildew & $P l r$ & & & & & & & & \\
\hline Oídio (Powdery mildew) & $p m-1.1$ & $p m-2.1$ & & & & & $p m-7.1$ & & \\
\hline Oídio (Powdery mildew) & & $p m-2.2$ & & & & & & & \\
\hline Big-vein (MLBVV) & & & $B V 1$ & $B V 2$ & $B V 4$ & $B V 5$ & & & \\
\hline Big-vein (MLBVV) & & & & $B V 3$ & & & & & \\
\hline Murcha de Fusário & $q F U S 1.1$ & FUS2 & & qFUS4.1 & & & FUS3 & qFUS8.1 & \\
\hline Murcha de Fusário & qFUS1.2 & RRD2 & & & & & & & \\
\hline Antracnose & & qANT1 & & & & & & ANT3 & \\
\hline Mancha Bacteriana & & Xar1 e Xcvr & & & & & & & \\
\hline Hypersensitive bacterial & $A v r B$ & & & & & & & AvrPpic & \\
\hline Hypersensitive bacterial & AvRpt2 & & & & & & & AvrRps4 & \\
\hline Hypersensitive bacterial & AvrRpm1 & & & & & & & AvrPo & \\
\hline
\end{tabular}

A localização dos genes de resistência foi complilada a partir de artigos científicos, livros e capítulos de livros, Dissertações, Teses e relatórios de pesquisa. 


\section{REFERÊNCIAS BIBLIOGRÁFICAS}

AGRAMA, H.A.; EIZENGA, G.C. \& YAN, W. 2007. Association mapping of yield and its components in rice cultivars. Molecular Breeding 19:341-356.

ALMEIDA, D. 2006. Asteráceas. Manual de Culturas Hortícolas-Volume II. Editorial Presença. Lisboa. p.156-158.

ANSARI, A. M. 2015. Molecular markers in vegetable improvement. Horticultural Biotechnology Research 1: 5-10.

ARUGA, D.; TSUCHIYA, N.; MATSUMURA, H.; MATSUMOTO, E. \& HAYASHIDA, N. 2012. Analysis of RAPD and AFLP markers linked to resistance to Fusarium oxysporum $\mathrm{f}$. sp. lactucae race 2 in lettuce (Lactuca sativa L.). Euphytica 187:1-9.

ARUMUGANATHAN, K. \& EARLE, E.D. 1991. Estimation of nuclear DNA content of plants by flow cytometry. Plant Molecular Biology Reporter 9: 229-241.

ARYA, P.; KUMAR, G.; ACHARYA, V. \& SINGH, A. K. 2014. Genome-wide identification and expression analysis of NBS-encoding genes in Malus domestica and expansion of NBS genes family in Rosaceae. Plos One 9:e107987.

ATKINSON, L.D.; MCHALE, L.K.; TRUCO, M.J.; HILTON, H.W.; LYNN, J.; SCHUT, J.W.; MICHELMORE, R.W.; HAND, P. \& PINK, D.A. 2013. An intra-specific linkage map of lettuce (Lactuca sativa) and genetic analysis of postharvest discolouration traits. Theoretical and Applied Genetics 126:2737-2752.

BAE, J.; HALTERMAN, D. \& JANSKY, H. 2008. Development of a molecular marker associated with Verticillium wilt resistance in diploid interspecific hybrids. Molecular Breeding 22:61-69.

BASTEN, C. J.; WEIR, B.S. \& ZENG, Z.B. 2001. QTL Cartographer: A Reference Manual and Tutorial for QTL Mapping. Program in Statistical Genetics. Bioinformatics Research Center, Department of Statistics, North Carolina State University, Raleigh, NC.

BECRAFT, P.W. 2002. Receptor kinase signaling in plant development. Annual Review of Cell Developmental Biology 18:163-192.

BENDAHMANE, A.; KANYUKA, K. \& BAULCOMBE, D.C. 1999. The Rx gene from potato controls separate virus resistance and cell death responses. Plant Cell 11:781-792. 
BENT, A.F. 1996. Plant disease resistance genes: function meets structure. The Plant Cell 8:1757-1771.

BENTLEY, D.R.; BALASUBRAMANIAN, S.; SWERDLOW, H.P.; SMITH, G.P.; MILTON, J.; BROWN, C.G.; HALL, K.P.; EVERS, D.J.; BARNES, C.L.; BIGNELL, H.R. et al. 2008. Accurate whole human genome sequencing using reversible terminator chemistry. Nature 456: 53-59.

BHATTRAMAKKI, D.; DOLAN, M. HANAFEY, M.; WINELAND, R.; VASKE, D.; REGISTER III, J.C.; TINGEY, S.V. \& RAFALSKI, A. 2002. Insertion-deletion polymorphisms in 3 ' regions of maize genes occur frequently and can be used as highly informative genetic markers. Plant Molecular Biology 48: 539-547.

BLANCARD, D.; LOT, H. \& MAISONNEUVE, B. 2006. A Colour Atlas of Diseases of Lettuce and Related Salad Crops. Observation, Biology and Control. Manson Publishing Ltd. Academic Press. London, UK.

BLEECKER, A.B. \& KENDE, H. 2000. Ethylene: A gaseous signal molecule in plants. Annual Review of Cell and Developmental Biology 16:1-18.

BOLAND, J. F.; CHUNG, C.C.; ROBERSON, D.; MITCHELL, J.; ZHANG, X.; IM, K. M.; HE, J.; CHANOCK, S.J.; YEAGER, M. \& DEAN, M. 2013. The new sequencer on the block: comparison of Life Technology's Proton sequencer to an Illumina HiSeq for whole-exome sequencing. Human genetics 132:1153-1163.

BOLLER, T. \& FELIX, G. 2009. A renaissance of elicitors: perception of microbe-associated molecular patterns and danger signals by pattern-recognition receptors. Annual Review of Plant Biology 60:379-406.

BOLSER, D.M.; KERHORNOU, A.; WALTS, B. \& KERSEY, P. 2015. Triticeae resources in Ensembl Plants. Plant and Cell Physiology 56:e3.

BOYD, L.A.; RIDOUT, C.; O'SULLIVAN, D.M.; LEACH, J.E. \& LEUNG, H. 2013. Plantpathogen interactions: disease resistance in modern agriculture. Trends Genetics 29:233240 .

CABRAL, C.S. 2012. Caracterização de isolados de Fusarium oxysporum f. sp. lactucae das Regiões Sul e Sudeste do Brasil e identificação de acessos de alface resistentes. Dissertação de Mestrado em Fitopatologia. Universidade Federal Rural de Pernambuco. Recife, Brasil.

CABRAL, C.S. \& REIS, A. 2013. Screening of lettuce accessions for resistance to Fusarium oxysporum f. sp. lactucae race 1. Tropical Plant Pathology 38:272-281. 
CABRAL, C.S.; BRUNELLI, K.R.; COSTA, H.; FONSECA, M.E.N.; BOITEUX, L.S. \& REIS, A. 2014. Identification of Fusarium oxysporum f. sp. lactucae race 1 as the causal agent of lettuce wilt in Brazil. Tropical Plant Pathology 39:197-202.

CARNEIRO, M. S. \& VIEIRA, M. L. C. 2002. Mapas genéticos em plantas. Bragantia 61: 89100 .

CASTAGNONE-SERENO, P.; VANLERBERGHE-MASUTTI, F. \& LEROY, F. 1994. Genetic polymorphism between and within Meloidogyne species detected with RAPD markers. Genome 37:904-909.

CHANDRA-NAYAKA, S.; UDAYA SHANNKAR, A.C.; NIRANJANA, S.R.; REDDY, M.S. \& PRAKASH, H.S. 2010. Detection and quantification of fumonisins from Fusarium verticillioides in maize grown in southern India. World Journal Microbiology Biotechnology 26:71-78.

CHRISTOPOULOU, M.; McHALE, L.K.; KOZIK, A.; REYES-CHIN WO, S.; WROBLEWSKI, T. \& MICHELMORE, R.W. 2015a. Dissection of two complex clusters of resistance genes in lettuce (Lactuca sativa). Molecular Plant-Microbe Interactions 28:751-765.

CHRISTOPOULOU, M.; WO, S.R.C.; KOZIK, A.; McHALE, L.K.; TRUCO, M.J.; WROBLEWSKI, T. \& MICHELMORE, R.W. 2015b. Genome-wide architecture of disease resistance genes in lettuce. G3: Genes| Genomes| Genetics 5: 2655-2669.

CLARK, S.E.; WILLIAMS, R.W. \& MEYEROWITZ, E.M. 1997. The CLAVATA 1 gene encodes a putative receptor kinase that controls shoot and floral meristem size in Arabidopsis. Cell 89:575-585.

COLLARD, B.C.Y.; JAHUFER, M.Z.Z.; BROUWER, J.B. \& PANG, E.C.K. 2005. An introduction to markers, quantitative trait loci (QTL) mapping and marker-assisted selection for crop improvement: The basic concepts. Euphytica 142:169-196.

COLLARD, B.C.Y. \& MACKILL, D.J. 2008. Marker-assisted selection: an approach for precision plant breeding in the twenty-first century. Philosophical Transactions of the Royal Society B: Biological Sciences 363:557-572.

CRAIG, D.W.; PEARSON, J.V.; SZELINGER, S.; SEKAR, A.; REDMAN, M.; CORNEVEAUX, J.J.; PAWLOWSKI, T.L.; LAUB, T.; NUNN, G. STEPHAN, D.A.; HOMER, N. \& HUENTELMAN, M.J. 2008. Identification of genetic variants using barcoded multiplexed sequencing. Nature Methods 5:887-893.

CRUTE, I.R. \& JOHNSON, A.G. 1976. The genetic relationship between races of Bremia lactucae and cultivars of Lactuca sativa. Annals of Applied Biology 83:125-137. 
CRUZ, C. D. 2005. Princípios de genética quantitativa. UFV. Viçosa, MG.

D'ANDREA, L.; FELBER, F. \& GUADAGNUOLO, R. 2008. Hybridization rates between lettuce (Lactuca sativa) and its wild relative ( $L$. serriola) under field conditions. Environmental Biosafety Research 7:61-71.

DANGL, J.L.; HORVATH, D.M. \& STASKAWICZ, B.J. 2013. Pivoting the plant immune system from dissection to deployment. Science 341:746-751.

DAVEY, J.W.; HOHENLOHE, P.A.; ETTER, P.D.; BOONE, J.Q.; CATCHEN, J.M. \& BLAXTER, M.L. 2011. Genome-wide genetic marker discovery and genotyping using next-generation sequencing. Nature Reviews Genetics 12:499-510.

DELLA VECCHIA, P.T.; KOCH, P.S.; KIKUCHI, M. 1999.Vera: nova cultivar de alface crespa resistente ao florescimento prematuro. Horticultura Brasileira 17:171.

DESCHAMPS, S.; LLACA, V. \& MAY, G.D. 2012. Genotyping-by-sequencing in plants. Biology 1:460-483.

DIXON, M.S.; JONES, D.A.; KEDDIE, J.S.; THOMAS, C.M.; HARRISON, K. \& JONES, J.D. 1996. The tomato Cf-2 disease resistance locus comprises two functional genes encoding leucine-rich repeat proteins. Cell 84:451-459.

DIXON, M.S.; HATZIXANTHIS, K.; JONES, D.A.; HARRISON, K. \& JONES, J. 1998. The tomato Cf-5 disease resistance gene and six homologs show pronounced allelic variation in leucine-rich repeat copy number. Plant Cell 10:1915-1925.

ELLIS, P.; MCCLEMENT, S.; SAW, P.; PHELPS, K.; VICE, W.; KIFT, N.; ASTLEY, D. \& PINK, D. 2002. Identification of sources of resistance in lettuce to the lettuce root aphid, Pemphigus bursarius. Euphytica 125:305-315.

ELSHIRE, R.; GLAUBITZ, J.C; SUN, Q.; POLAND, J.A.; KAWAMOTO, K.; BUCKLER, E.S. \& MITCHELL, S.E. 2011. A robust, simple genotyping-by-sequencing (GBS) approach for high diversity species. Plos One 6:e19379.

FALEIRO, F.B. 2007. Marcadores Genético-Moleculares Aplicados a Programas de Conservação e Uso de Recursos Genéticos. Embrapa Cerrados. Planaltina, DF.

FARRARA, B.F.; ILOTT, T.W. \& MICHELMORE, R.W. 1987. Genetic analysis of factors for resistance to downy mildew (Bremia lactucae) in species of lettuce (Lactuca sativa and $L$. serriola). Plant Pathology 36: 499-514. 
FERREIRA, M.E. \& GRATTAPAGLIA, D. 1998. Introdução ao Uso de Marcadores Moleculares em Análise Genética. $3^{\mathrm{a}}$ edição. Embrapa. Brasília-DF.

FILGUEIRA, F.A.R. 2008. Asteráceas. Alface e outras folhosas. In: Filgueira, F.A.R. (ed.). Novo Manual de Olericultura: Agrotecnologia moderna para produção de hortaliças. $3^{\mathrm{a}}$ ed. revista e ampliada. UFV. Viçosa. p. 300-306.

FLOR, H. 1971. Current status of the gene-for-gene concept. Annual Review of Phytopathology 9:275-296.

FRADIN, E.F.; ZHANG, Z.; JUAREZ AYALA, J.C.; CASTROVERDE, C.D.; NAZAR, R.N.; ROBB, J.; LIU, CM. \& THOMMA, B.P. 2009. Genetic dissection of Verticillium wilt resistance mediated by tomato Ve1. Plant Physiology 150:320-332.

FRAVEL, D.; OLIVAIN, C. \& ALABOUVETTE, C. 2003. Fusarium oxysporum and its biocontrol. New Phytologist 157:493-502.

FREDERICK, R. D.; THILMONY, R. L.; SESSA, G. \& MARTIN, G. B. 1998. Recognition specificity for the bacterial avirulence protein AvrPto is determined by Thr-204 in the activation loop of the tomato Pto kinase. Molecular cell 2:241-245.

FUJINAGA, M.; OGISO, H.; TSUCHIYA, N. \& SAITO, H. 2001. Physiological specialization of Fusarium oxysporum oxysporum $\mathrm{f}$. sp. lactucae, a causal organism of fusarium root rot of crip head lettuce. Journal of General Plant Pathology 67:205-206.

FUJINAGA, M.; OGISO, H.; TSUCHIYA, N. \& SAITO, H. 2003. Race 3, a new race of Fusarium oxysporum f. sp. lactucae determined by a differencial system with commercial cultivars. Journal of General Plant Pathology 69:23-28.

GARIBALDI, A.; GILARDI, G. \& GIULLINO, M.L. 2002. First report of Fusarium oxysporum on lettuce in Europe. Plant Disease 86:1052.

GARIBALDI, A.; GILARDI, G. \& GULLINO, M.L. 2004a. Seed transmission of Fusarium oxysporum f. sp. lactucae. Phytoparasitica 32:61-65.

GARIBALDI, A.; GILARDI, G. \& GULLINO, M.L. 2004b. Varietal resistance of lettuce to Fusarium oxysporum f. sp. lactucae. Crop Protection 23:845.

GILARDI, G.; FRANCO ORTEGA, S.; RIJSWICK, P. C. J.; ORTU, G.; GULLINO, M. L. \& GARIBALDI, A. 2016. A new race of Fusarium oxysporum f. sp. lactucae of lettuce. Plant Pathology. 
GOHRE, V. \& ROBATZEK, S. 2008. Breaking the barriers. microbial effector molecules subvert plant immunity. Annual Reviews of Phytophathology 46:189-215.

GOODSTEIN, D.M.; SHU, S.; HOWSON, R.; NEUPANE, R.; HAYES, R.D.; FAZO, J.; MITROS, T.; DIRKS, W.; HELLSTEN, U.; PUTNAM, N. \& ROKHSAR, D.S. 2012. Phytozome: A comparative platform for green plant genomics. Nucleic Acids Research 40:D1178-D1186.

GORDON, T.R., \& KOIKE, S.T. 2015. Management of Fusarium wilt of lettuce. Crop Protection 73:45-49.

GORE, M.A.; WRIGHT, M.H.; ERSOZ, E.S.; BOUFFARD, P.; SZEKERES, E.S.; JARVIE, T.P.; HURWITZ, B.L.; NARECHANIA, A.; HARKINS, T.T.; GRILLS, G.S.; WARE, D.H. \& BUCKLER, E.S. 2009. Large-scale discovery of gene-enriched SNPs. The Plant Genome 2:121-133.

GRANT, J. J. \& LOAKE, G. J. 2000. Role of reactive oxygen intermediates and cognate redox signaling in disease resistance. Plant Physiology. 124:21-30.

GRATTAPAGLIA, D.; SILVA-JUNIOR, O.B. KIRST, M.; de LIMA, B.M.; FARIA, D.A. \& PAPPAS, G.J. 2011. High-throughput SNP genotyping in the highly heterozygous genome of Eucalyptus: assay success, polymorphism and transferability across species. BMC Plant Biology 11:65.

GUIMARÃES, C.T.; SCHUSTER, I.; MAGALHÃES, J.V. \& SOUZA JR, C.L. 2006. Marcadores moleculares no Melhoramento de Plantas. In: Borém, A; Caixeta, E.T. Marcadores Moleculares. UFV. Viçosa, MG.

GUO, Y. L.; FITZ, J.; SCHNEEBERGER, K.; OSSOWSKI, S.; CAO, J. \& WEIGEL, D. 2011. Genome-wide comparison of nucleotide-binding site-leucine-rich repeat-encoding genes in Arabidopsis. Plant Physiology 157:757-769.

GURURANI, M.A.; VENKATESH, J.; UPADHYAYA, C.P. \& NOOKARAJU, A. 2012. Plant disease resistance genes: current and future directions. Physiological and Molecular Plant Pathology 78:51-65.

HAMMOND-KOSACK, K.E. \& JONES, J.D.G. 1997. Plant disease resistance genes. Annual Review of Plant Physiology and Plant Molecular Biology 48:575-607.

HAMMOND-KOSACK, K.E. \& PARKER, J.E. 2003. Deciphering plant-pathogen communication: fresh perspectives for molecular resistance breeding. Current Opinion in Biotechnology 14:177-193. 
HAMMOND-KOSACK, K.E. \& KANYUKA, K. 2007. Resistance genes (R genes) in plants. eLS.

HAYES, R.J.; MCHALE, L.K.; VALLAD, G.E.; TRUCO, M.J.; MICHELMORE, R.W.; KLOSTERMAN, S.J.; MARUTHACHALAM, K. \& SUBBARAO, K.V. 2011. The inheritance of resistance to Verticillium wilt caused by race 1 isolates of Verticillium dahliae in the lettuce cultivar La Brillante. Theoretical and Applied Genetics 123:509-517.

HE, J.; ZHAO, X.; LAROCHE, A.; LU, Z.X.; LIU, H. \& LI, Z. 2014. Genotyping-by-sequencing (GBS), an ultimate marker-assisted selection (MAS) tool to accelerate plant breeding. Frontiers in Plant Science 5:484.

HEATH, M.C. 2000. Nonhost resistance and nonspecific plant defenses. Current Opinion Plant Biology 3:315-319.

HENZ, G.P. \& SUINAGA, F. 2009. Tipos de alfaces cultivadas no Brasil. (Comunicado Técnico Número 75). Embrapa Hortaliças, Brasília-DF. 7pp.

HILL, M.; WITSENBOER, H.; ZABEAU, M.; VOS, P.; KESSELI, R. \& MICHELMORE, R.W. 1996. PCR-based fingerprinting using AFLPs as a tool for studying genetic relationships in Lactuca spp. Theoretical and Applied Genetics 93:1202-1210.

HOLT III, F.B., HUBERT, D. A. \& DANGL, J.L. 2003. Resistance gene signaling in plants complex similarities to animal innate immunity. Current Opinion in Immunology 15:20-25.

HU, J.; OCHOA, O.E.; TRUCO, M.J. \& VICK, B.A. 2005. Application of the TRAP technique to lettuce (Lactuca sativa L.) genotyping. Euphytica 144:225-235.

HUA-VAN, A.; DAVIÈRE, J. M.; KAPER, F.; LANGIN, T. \& DABOUSSI, M.J. 2000. Genome organization in Fusarium oxysporum: clusters of class II transposons. Current Genetics 37:339-576.

HUANG, J.H. \& LO, C.T. 1998. Wilt of lettuce caused by Fusarium oxysporum in Taiwan. Plant Pathology Bulletin 7:150-153.

HUBBARD, J.C. \& GERIK, J.S. 1993. A new disease of lettuce incited by Fusarium oxysporum f. sp. lactucum forma specialis nov. Plant Disease 77:750-754.

HULBERT, S.H. \& MICHELMORE, R.W. 1985. Linkage analysis of genes for resistance to downy mildew (Bremia lactucae) in lettuce (Lactuca sativa). Theoretical and Applied Genetics 70:520-528. 
ILOTT, T. W.; DURGAN, M. E. \& MICHELMORE, R. W. 1987. Genetics of virulence in California populations of Bremia lactucae (lettuce downy mildew). Phytopathology 77:1381-1386.

INNOCENTI, G.; ROBERTI, R. \& PIATTONI, F. 2015. Biocontrol ability of Trichoderma harzianum strain T22 against Fusarium wilt disease on water-stressed lettuce plants. BioControl. 60:573-581.

INOUE, T.; HIGUCHI, M.; HASHIMOTO, Y.; SEKI, M.; KOBAYASHI, M.; KATO, T.; TABATA, S.; SHINOZAKI, K. \& KAKIMOTO, T. 2001. Identification of CRE1 as a cytokinin receptor from Arabidopsis. Nature 409:1060-1063.

JANSEN, R.C. 1993. Interval mapping of multiple quantitative trait loci. Genetics 135:205-211.

JANSKY, S.; ROUSE, D.I. \& KAUTH, P.J. 2004. Inheritance of resistance to Verticillium dahliae in diploid interspecific potato hybrids. Plant Disease 88:1075-1078

JEUKEN, M.; VAN WIJK, R.; PELEMAN, J. \& LINDHOUT, P. 2001. An integrated interspecific AFLP map of lettuce (Lactuca) based on two L. sativa $\times$ L. saligna $\mathrm{F}_{2}$ populations. Theoretical and Applied Genetics 103:638-647.

JIANG, G.L. 2013. Molecular markers and marker-assisted breeding in plants. Plant Breeding from Laboratories to Fields 45-83.

JIN, H.; COMINELLI, E.; BAILEY, P.; PARR, A.; MEHRTENS, F.; JONES, J.; TONELLI, C.; WEISSHAAR, B. \& MARTIN, C. 2000. Transcriptional repression by AtMYB4 controls production of UV-protecting sunscreens in Arabidopsis. The EMBO Journal 19:61506161.

JOHNSON, W.C.; JACKSON, L.E.; OCHOA, O.; VAN WIJK, R.; PELEMAN, J., CLAIR, D. S. \& MICHELMORE, R.W. 2000. Lettuce, a shallow-rooted crop, and Lactuca serriola, its wild progenitor, differ at QTL determining root architecture and deep soil water exploitation. Theoretical and Applied Genetics 101:1066-1073.

JONES, J.D. \& DANGL, J.L. 2006. The plant immune system. Nature 444: 323-329.

KANAZIN, V.; MAREK, L.F. \& SHOEMAKER, R.C. 1996. Resistance genes analogs are conserved and clustered in soybean. Proceedings of the National Academy of Sciences USA 93:11746-11750.

KANDEL, R. 2015. Identification of QTLs for Liriomyza trifolii resistance and two agronomic traits in lettuce. Doctoral dissertation. UNIVERSITY OF FLORIDA. 
KAO, CH.; ZENG, ZB. \& TEASDALE, R.D. 1999. Multiple interval mapping for quantitative trait loci. Genetics 152:1203-1216.

KESSELI, R.V. \& MICHELMORE, R.W. 1986. Genetic variation and phylogenies detected from isozyme markers in species of Lactuca. Journal of Heredity 77:324-331.

KESSELI, R.V; OCHOA, O. \& MICHELMORE, R.W. 1991. Variation at RFLP loci in Lactuca spp. and origin of cultivated lettuce (L. sativa). Genome 34:430-436.

KESSELI, R.V.; PARAN, I. \& MICHELMORE, R.W. 1994. Analysis of a detailed genetic linkage map of Lactuca sativa (lettuce) constructed from RFLP and RAPD markers. Genetics 136:1435-1446.

KOHLER, A.; RINALDI, C.; DUPLESSIS, S.; BAUCHER, M.; GEELEN, D.; DUCHAUSSOY, F.; MEYERS, B.C.; BOERJAN, W. \& MARTIN, F. 2008. Genome-wide identification of NBS resistance genes in Populus trichocarpa. Plant molecular biology 66:619-636.

KRÜGER, J.; THOMAS, C.M.; GOLSTEIN, C.; DIXON, M.S.; SMOKER, M.; TANG, S.K.; MULDER, L. \& JONES, J.D.G. 2002. A tomato cysteine protease required for $C f$-2dependent disease resistance and suppression of autonecrosis. Science 296:744-747.

KUANG, H.; WOO, S.S.; MEYERS, B.C.; NEVO, E. \& MICHELMORE, R.W. 2004. Multiple genetic processes result in heterogeneous rates of evolution within the major cluster disease resistance genes in lettuce. Plant Cell 16:2870-2894.

KUANG, H; VAN ECK, H.J.; SICARD, D.; MICHELMORE, R.W. \& NEVO, E. 2008. Evolution and genetic population structure of prickly lettuce (Lactuca serriola) and its RGC2 resistance gene cluster. Genetics 178:1547-1558.

KWON, S.; SIMKO, I.; HELLIER, B.; MOU, B. \& HU, J. 2013. Genome-wide association of 10 horticultural traits with expressed sequence tag-derived SNP markers in a collection of lettuce lines. The Crop Journal 1:25-33.

LANDER, E.S. \& BOTSTEIN, D. 1989. Mapping mendelian factors underlying quantitative traits using RFLP linkage maps. Genetics 121:185-199.

LEBEDA, A.; KŘÍSTKOVÁ, E.; KITNER, M.; MIESLEROVÁ, B.; JEMELKOVÁ, M. \& PINK, D. A. 2014. Wild Lactuca species, their genetic diversity, resistance to diseases and pests, and exploitation in lettuce breeding. European Journal of Plant Pathology 138:597640 .

LI, J.M. \& CHORY, J. 1997. A putative leucine-rich repeat receptor kinase involved in brassinoteroid signal transduction. Cell 90: 929-938. 
LIEVENS, B.; REP, M; THOMMA, B.P.H.J. 2008. Recent developments in the molecular discrimination of formae speciales of Fusarium oxysporum. Pest Management Science 64:781788.

LIN, Y.H.; LAI, P.J.; CHANG, T.H.; WAN, Y.L.; HUANG, J.W.; HUANG, J.H. \& CHANG, P.F.L. 2014. Genetic diversity and identification of race 3 of Fusarium oxysporum f. sp. lactucae in Taiwan. European Journal of Plant Pathology 140:721-733.

LIU, B.H. 1998. Statistical Genomics. CRC. New York.

LIU, J.; LIU, X.; DAI, L. \& WANG, G. 2007. Recent progress in elucidating the structure, function and evolution of disease resistance genes in plants. Journal of Genetics and Genomics 34:765-776.

LOPES, C.A.; QUEZADO-DUVAL, A. \& REIS, A. 2010. Doenças da Alface. Brasília: Embrapa Hortaliças. Brasília-DF.

LYNCH, M. \& WALSH, B. 1998. Genetics and analysis of quantitative traits. Sinauer Associates. Sunderland.

MACKEY, D.; HOLT III, B. F.; WIIG, A. E. \& DANGL, J. 2002. RIN4 Interacts with Pseudomonas syringae type III effector molecules and is required for RPM1-mediated resistance in Arabidopsis. Cell 108:743-754.

MAISONNEUVE, B.; BELLEC, Y.; ANDERSON, P. \& MICHELMORE, R.W. 1994. Rapid mapping of two genes for resistance to downy mildew from Lactuca serriola to existing clusters of resistance genes. Theoretical and Applied Genetics 89:96-104.

MALBRÁN, I.; MOURELOS, C.A.; MITIDIERI, M.S.; RONCO, B.L. \& LORI, GA. 2014. Fusarium wilt of lettuce caused by Fusarium oxysporum f. sp. lactucae in Argentina. Plant disease 98:1281.

MARATHE, R \& DINESH-KUMAR, S.P. 2003. Plant defense: one post, multiple guards? Molecular Cell 11:284-286.

MATHERON, M.E. \& KOIKE, S.T. 2003. First report of Fusarium wilt of lettuce caused by Fusarium oxysporum f.sp. lactucae in Arizona. Plant Disease 87:1265.

MATHERON, ME.; MCCREIGHT, J.D.; TICKES, B.R. \& PORCHAS, M. 2005. Effect of planting date, cultivar, and stage of plant development on incidence of Fusarium wilt of lettuce in desert production fields. Plant Disease 89:565-570. 
MATHERON, M.E. \& PORCHAS, M. 2010. Evaluation of soil solarization and flooding as management tools for Fusarium wilt of lettuce. Plant Disease 94:1323-1328.

MATHERON, M.E. 2015. Biology and management of Fusarium wilt of lettuce.

MATIOLI, S.R. 2001. Métodos baseados em PCR para análise de polimorfismo de ácidos nucléicos. In: Matioli S.R. (Ed.). Biologia Molecular e Evolução. Holos. Ribeirão Preto-SP, Brasil.

MATUO, T. \& MOTOHASHI, S. 1967. On Fusarium oxysporum f. sp. lactucae n.f. causing root of lettuce. Transactions of Mycological Society of Japan 8:13-15.

MBOFUNG, G.Y.; HONG, S.G. \& PRYOR, B.M. 2007. Phylogeny of Fusarium oxysporum f.sp. lactucae interred from mitochondrial small subunit, elongation factor 1- $\alpha$, and nuclear ribosomal intergenic spacer sequence data. Mycology 97:87-98.

MBOFUNG, G.Y. \& PRYOR, B.M. 2010. A PCR-based assay for detection of Fusarium oxysporum f. sp. lactucae in lettuce seed. Plant Disease 94:860-866.

MCCOUCH, S.R. \& DOERGE, R.W. 1995. QTL mapping in rice. Trends in Genetics 11:482487.

MCCREIGHT, J.D.; MATHERON, M.E.; TICKES, B.R. \& PLANTTS, B. 2005. Fusarium wilt race 1 on lettuce. HortScience 40:529-531.

MCHALE, L.K. 2008. Global analysis of disease resistance genes in lettuce. Ph.D. diss., University of California, Davis, CA, USA.

MCHALE, L.K.; TRUCO, M.J.; KOZIK, A.; LAVELLE, DO.; OCHOA, O.E.; WROBLEWSKI, T.; KNAPP, S.J. \& MICHELMORE, R.W. 2009. The genomic architecture of disease resistance in lettuce. Theoretical and Applied Genetics 118:565-580.

MEYERS, B.C.; CHIN, D.B.; SHEN, K.A.; SIVARAMAKRISHNAN, S.; LAVELLE, D.O.; ZHANG, Z. \& MICHELMORE, R.W. 1998. The major resistance gene cluster in lettuce is highly duplicated and spans several megabases. Plant Cell 10:1817-1832.

MEYERS, B.C.; KOZIK, A.; GRIEGO, A.; KUANG, H. \& MICHELMORE, R.W. 2003. Genome-wide analysis of NBS-LRR encoding genes in Arabidopsis. Plant Cell 15:809834.

MICHELMORE, R.W.; PARAN, I. \& KESSELI, R.V. 1991. Identification of markers linked to disease-resistance genes by bulked segregant analysis: a rapid method to detect markers in 
specific genomic regions by using segregating populations. Proceedings of the National Academy of Sciences USA 88: 9828-9832.

MICHELMORE, R.W. \& MEYERS, B.C. 1998. Clusters of resistance genes in plants evolve by divergent selection and a birth-and-death process. Genome Research 8:1113-1130.

MILCHELMORE, R.W.; OCHOA, O. \& WONG, J. 2009. Bremia lactucae and lettuce downy midew. In: Lamour, K. \& Kamoun, S. Oomycete Genetics and Genomics: Diversity, Plant and Animal Interactions, and Toolbox. (eds.). John Wiley \& Sons. Hoboken, NJ, U.S.A. p.241-262.

MICHELMORE, R.W. 2010. Genetic variation in lettuce. California leafy greens research program,calgreens.org/control/uploads/Michelmore_Variation_report_20092010_final_(2)1.pdf

MICHELMORE, R.W.; CHRISTOPOULOU, M. \& CALDWELL, K.S. 2013. Impacts of resistance gene genetics, function, and evolution on a durable future. Annual Review Phytopathology 51:291-319.

MILACH, S.C.K. 1998. Marcadores de DNA. Biotecnologia, Ciência \& Desenvolvimento 5:1417.

MILLANI, M.J.; EREBARIAN, H.R. \& ALIZADEH, A. 1999. Occurrence of Fusarium wilt of lettuce in Shahr- Ray, Varamim and Karaj areas. Journal of Plant Pathology 35:121.

MOHAN, M.; NAIR, S.; BHAGWAT, A.; KRISHNA, T.G.; YANO, M.; BHATIA, C.R. \& SASAKI, T. 1997. Genome mapping, molecular markers and marker-assisted selection in crop plants. Molecular Breeding 3: 87-103.

MONDRAGON-PALOMINO, M. \& GAUT, B.S. 2005. Gene conversion and the evolution of three leucine-rich repeat gene families in Arabidopsis thaliana. Molecular Biology and Evolution 22: 2444-2456.

MORGANTE, M; OLIVIERI, A.M. 1993. PCR-amplified microssatélites as markers in plant genetics. The Plant Journal 3:175-182.

MORENO-V’AZQUEZ, S.; OCHOA, O.E.; FABER, N.; CHAO, S.; JACOBS, J.M.E.; MAISONNEUVE, B.; KESSELI, R.V. \& MICHELMORE, R.W. 2003. SNP-based codominant markers for a recessive gene conferring resistance to corky root rot (Rhizomonas suberifaciens) in lettuce (Lactuca sativa). Genome 46:1059-1069. 
MOU, B. 2008. Lettuce. In: Prohens, J.; Nuez, F. \& Carena, M.J. (eds.). Handbook of Plant Breeding. Vegetables I. Asteraceae, Brassicaceae, Chenopodiaceae, and Cucurbitaceae. Springer. New York. p.75-116.

NIEW“OHNER, J.; SALAMINI, F. \& GEBHARDT, C. 1995. Development of PCR assays diagnostic for RFLP marker alleles closely linked to alleles Grol and $H 1$, conferring resistance to the root cyst-nematode Globodera rostochiensis in potato. Molecular Breeding 1: $65-78$.

NIKAIDO, A.M.; UJINO, T.; IWATA, H.; YOSHIMURA, K.; YOSHIMURA, H.; SUYAMA, Y.; MURAI, M.; NAGASAKA, K. \& TSUMURA, Y. 2000. AFLP and CAPS: linkage maps of Crytomeria japonica. Theoretical and Applied Genetics 100: 825-831.

NIMCHUK, Z.; EULGEM, T.; HOLT, B.F. \& DANGL, J.L. 2003. Recognition and response in the plant immune system. Annual Review of Genetics 37:579-609.

NOMURA, K.; MELOTTO, M.; \& HE, S. Y. 2005. Suppression of host defense in compatible plant-Pseudomonas syringae interactions. Current Opinion in Plant Biology 8:361-368.

NORDBERG, H.; CANTOR, M.; DUSHEYKO, S.; HUA, S.; POLIAKOV, A.; SHABALOV, I.; SMIRNOVA, T.; GRIGORIEV, IV. \& DUBCHAK, I. 2014. The genome portal of the department of energy joint genome institute: updates. Nucleic Acids Research 42:D26D31.

NÜRNBERGER, T.; BRUNNER, F.; KEMMERLINGM, B. \& PIATER, L. 2004. Immunological Reviews 198:249-266.

OERKE, E.C. \& DEHNE, H.W. 2004. Safeguarding production-losses in major crops and the role of crop protection. Crop Protection 23:275-285.

OGISO, H.; FUJINAGA, M.; SAITO, H.; TAKEHARA, T. \& YAMANAKA, S. 2002. Physiological races and vegetative compatibility groups of Fusarium oxysporum f. sp lactucae isolated from crisphead lettuce in Japan. Journal of General Plant Pathology 68:292-299.

OLIVEIRA, M.D.L.S.; FIGUEIREDTO, E.L.; LOURENÇO, L.D.F.H. \& LOURENÇO, V.V. 2006. Análise microbiológica de alface (Lactuta sativa, L.) e tomate (Solanum lycopersicum, L.), comercializados em feiras-livres da cidade de Belém, Pará. Higiene alimentar 20: 96-100.

PARRA, L.; MAISONNEUVE, B.; LEBEDA, A.; SCHUT, J.; CHRISTOPOULOU, M.; JEUKEN, M.; MCHALE, L.; TRUCO, M.J.; CRUTE, I. \& MICHELMORE, R. 2016. Rationalization of genes for resistance to Bremia lactucae in lettuce. Euphytica 1-18. 
PASQUALI, M.; GILARDI, G.; GULlINO, M.L. \& GARIBALDI, A. 2003. Fusarium oxysporum f. sp. lactucae on lettuce: vegetative compatibility and RAPD analysis. Phytopathology 53:73-75.

PASQUALI, M.; DEMATHEIS, F.; GILARDI, G.; GULLINO, M.L. \& GARIBALDI, A. 2005. Vegetative compatibility groups of Fusarium oxysporum f. sp. lactucae from lettuce. Plant Disease 89:237-240.

PASQUALI, M.; DEMATHEIS, F.; GULLINO, M.L. \& GARIBALDI, A. 2007. Identification of race 1 of Fusarium oxysporum f. sp. lactucae on lettuce by inter-retrotranposon sequencechacarterized amplified region technique. Phytopathology 97:987-996.

PATERSON, A.H. 1996. Making genetic maps. In: Paterson, A.H. (ed.). Genome Mapping in Plants. R.G. Landes Company. Austin, Texas. p. 23-39.

PELEMAN, J.D.; ROUPPE, VAN DER. VOORT, J.R. 2003. The challenges in marker assisted breeding. In: van Hintum THJL.; Lebeda, A.; Pink, D. \& Schut, J.W. (eds.). Eucarpia Leafy Vegetables. CGN. Noorwijkerhout. The Netherlands. p. 125-130.

PERAZA-ECHEVERRIA, S.; JAMES-KAY, A.; CANTO-CANCHÉ, B. \& CASTILLOCASTRO, E. 2007. Structural and phylogenetic analysis of Pto-type disease resistance gene candidates in banana. Molecular Genetics and Genomics 278: 443-453.

PINTO, M.D.S.T.; RIBEIRO, J.M., \& DE OLIVEIRA, E.A.G. 2011. O estudo de genes e proteínas de defesa em plantas. Revista Brasileira de Biociências 9.

PORTER, B.; PAIDI, M.; MING, R.; ALAM, M.; NISHIJIMA, W.T. \& ZHU, Y.J. 2009. Genome wide analysis of Carica papaya reveals a small NBS resistance gene family. Molecular Genetics and Genomics 281:609-626.

QUAIL, M.A.; SMITH, M.; COUPLAND, P.; OTTO, T.D.; HARRIS, S.R.; CONNOR, T.R. BERTONI, A.; SWERDLOW, H. \& GU, Y. 2012. A tale of three next generation sequencing platforms: comparison of Ion Torrent, Pacific Biosciences and Illumina MiSeq sequencers. BMC Genomics 13: 341.

RAMALHO, M.A.P.; SANTOS, J.B. \& PINTO, C.A.B. 2008. Genética na Agropecuária. 4 ed. UFLA. Lavras, MG.

RAUSCHER, G. \& SIMKO, I. 2013. Development of genomic SSR markers for fingerprinting lettuce (Lactuca sativa L.) cultivars and mapping genes. BMC Plant Biology 13:11.

RESENDE, M.L.V.; SALGADO, S.M.L. \& CHAVES, Z.M. 2003. [Reactive oxygen species on plant defense responses to pathogens.] Fitopatologia Brasileira 28:123-130. 
REYNES-CHIN-WO, S.; WANG, Z.; BEITEL, C.; KOZIK, A.; CHI, S.; CHEN, W.; TRUCO, M.J.; XU, X.; FROENICKE, L.; LAVELLE, D.; YANG, B.; KORF, I.; WANG, J. \& MICHELMORE, R.W. 2012. Lettuce genome update. Plant \& Animal Genome XX, San Diego, CA, USA, W188.

RICHLY, E.; KURTH, J. \& LEISTER, D. 2002. Mode of amplification and reorganization of resistance genes during recent Arabidopsis thaliana Evolution. Molecular Biology and Evolution 19:76-84.

ROTHBERG, J.M.; HINZ, W.; REARICK, T.M.; SCHULTZ, J.; MILESKI, W.; DAVEY, M.; LEAMON, J.H.; JOHNSON, K.; MILGREW, M.J.; EDWARDS, M.; HOON, J.; SIMONS, J.F.; MARRAN, D.; MYERS, J.W.; DAVIDSON, J.F.; BRANTING, A.; NOBILE, J.R.; PUC, B.P.; LIGHT, D.; CLARK, T.A.; HUBER, M.; BRANCIFORTE, J.T.; STONER, I.B.; CAWLEY, S.E. \& LYONS, M. 2011. An integrated semiconductor device enabling non-optical genome sequencing. Nature 475: 348-352.

RYDER, E.J. 1999. Lettuce, Endive and Chicory. CABI Publishing. New York.

SAKIYAMA, N.S. 1993. Marcadores moleculares e as hortaliças. Horticultura Brasileira 11: 204-206.

SALA, F.C. \& COSTA, C.P. 2012. Retrospectiva e tendência da alfacicultura brasileira. Horticultura Brasileira 30: 187-194.

SALA, F.C. \& NASCIMENTO, W.M. 2014. Produção de sementes de alface. In: Nascimento, W.M. (ed.). Produção de Sementes de Hortaliças. Embrapa. Brasília, DF.

SALA, F.C. \& COSTA, C.P 2016. Melhoramento de alface. In: Nick, C. \& Bórem, A. Melhoramento de Hortaliças. (eds.). UFV.Viçoca, MG.

SCHEEL, D. 1998. Resistance response physiology and signal transduction. Current Opinion in Plant Biology 1:305-310.

SCHMID, K. J.; SORENSEN, T. R.; STRACKE, R.; TORJEK, O.; ALTMANN, T.; MICHELLOLDS, T. \& WEISSHAAR. 2003. Large-scale identification and analysis of genome wide single-nucleotide polymorphisms for mapping in Arabidopsis thaliana. Genome Research 13:1250-1257.

SCHUlTZ, J.; COPLEY, R.R.; DOERK, T.; PONTING, C.P. \& BORK, P. 2000. SMART: A web-based tool for the study of genetically mobile domains. Nucleic Acids Research 28:231-234. 
SCHUSTER, I. \& CRUZ, C.D. 2004. Estatística genômica aplicada a populações derivadas de cruzamentos controlados. UFV. Viçosa, MG.

SCHWESSINGER, B. \& ZIPFEL, C. 2008. News from the frontline: recent insights into PAMPtriggered immunity in plants. Current Opinion in Plant Biology 11:389-395.

SCOTT, J.C.; KIRKPATRICK, S.C. \& GORDON, T.R. 2010. Variation in susceptibility of lettuce cultivars to fusarium wilt caused by Fusarium oxysporum f. sp. lactucae. Plant Pathology 59:139-146.

SCOTT, J.C.; GORDON, T.R.; KIRKPATRICK, S.C.; KOIKE, S.T.; MATHERON, M.E.; OCHOA, O.E.; TRUCO, M.J. \& MICHELMORE, R.W. 2012. Crop rotation and genetic resistance reduce risk of damage from Fusarium wilt in lettuce. California Agriculture 66:20-24.

SEKHWAL, M.K.; LI, P.; LAM, I.; WANG, X.; CLOUTIER, S. \& YOU, F.M. 2015. Disease resistance gene analogs (RGAs) in plants. International Journal of Molecular Sciences 16:19248-19290.

SHAO, Z.Q.; ZHANG, Y.M.; HANG, Y.Y.; XUE, J.Y.; ZHOU, G.C.; WU, P.; WU, X.Y.; WU, X.Z.; WANG, Q. \& CHEN, J.Q. 2014. Long-term evolution of nucleotide-binding siteleucine-rich repeat genes: understanding gained from and beyond the legume family. Plant Physiology 166:217-234.

SHEN, K.A.; CHIN, D.B.; ARROYO-GARCIA, R.; OCHOA, O.E.; LAVELLE, D.O.; WROBLEWSKI, T.; MEYERES, B.C \& MICHELMORE, R.W. 2002. Dm3 is one member of a large constitutively expressed family of nucleotide binding site-leucine-rich repeat encoding genes. Molecular Plant-Microbe Interactions 15:251-261.

SHIU, S.H.; BLECKER, A.B. 2001. Receptor-like kinases from Arabidopsis form a monophyletic gene family related to animal receptor kinases. Proceedings of the National Academy of Sciences 98:10763-10768.

SILVA, E.C.; MALUF, W.R.; LEAL, N.R. \& GOMES, L.A.A. 1999. Inheritance of bolting tendency in lettuce Lactuca sativa L. Euphytica 109:1-7.

SILVA, V. D.; BEZERRA NETO, F.; NEGREIROS, M.D. \& PEDROSA, J.F. 2000. Comportamento de cultivares de alface em diferentes espaçamentos sob temperatura e luminosidade elevadas. Horticultura Brasileira 18:183-187.

SILVA, E.C.2009. Anita: cultivar de alface de verão para cultivo protegido no solo e em hidroponia. Horticultura Brasileira 27: 260-262. 
SIMKO, I.; JANSKY, S.; STEPHENSON, S. \& SPOONER, D. 2007. Genetics of resistance to pests and disease. In: Vreugdenhil, D.; Bradshaw, J.; Gebhardt, C.; Govers, F.; Taylor, M.; MacKerron, D. \& Ross, H. (eds.). Potato Biology and Biotechnology: Advances and Perspectives. Elsevier.Oxford, UK. p. 117-155.

SIMKO, I. 2009. Development of EST-SSR markers for the study of population structure in lettuce (Lactuca sativa L.). Journal of Heredity 100: 256-262.

SIMKO, I.; PECHENICK, D.A.; MCHALE, L.K.; TRUCO, M.J.; OCHOA, O.E.; MICHELMORE, R.W. \& SCHEFFLER, B.E. 2010. Development of molecular markers for marker-assisted selection of dieback disease resistance in lettuce (Lactuca sativa). Acta Horticulture 859: 401.

SIMKO, I. 2013. Marker-assisted selection for disease resistance in lettuce. Translational Genomics for Crop Breeding 1:267-289.

SIMKO, I.; HAYES, R. J.; MOU, B. \& MCCREIGHT, J.D. 2014. Lettuce and spinach. Yield Gains in Major US Field Crops: 53-86.

SOUSA, M.V.; MACHADO, J.D.C.; SIMMONS, H.E. \& MUNKVOLD, G.P. 2015. Real- time quantitative PCR assays for the rapid detection and quantification of Fusarium oxysporum f. sp. phaseoli in Phaseolus vulgaris (common bean) seeds. Plant Pathology 64: 478-488.

SRINIVASAN K.; GILARDI G.; SPADARO D.; POLI A.; GULLINO ML. \& GARIBALDI, A. 2010. Molecular characterization though IGS sequencing of formae speciales of Fusarium oxyporum pathogenic on lamb's lettuce. Phytopathologia Mediterranea 49:309-320.

STASKAWICZ, B.J.; AUSUBEL, F.M.; BAKER, B.J.; ELLIS, J.G. \& JONES, J.D. 1995. Molecular genetics of plant disease resistance. Science 268:661-667.

STOFFEL, K.; VAN LEEUWEN, H.; KOZIK, A.; CALDWELL, D.; ASHRAFI, H.; CUI, X.; TAN, X.; HILL, T.; REYES-CHIN-WO, S.; TRUCO, M.J.; MICHELMORE, R.W. \& VAN DEYNZE, A. 2012. Development and application of a 6.5 million feature Affymetrix Genechip ${ }^{\circledR}$ for massively parallel discovery of single position polymorphisms in lettuce (Lactuca spp.). BMC Genomics 13: 185.

STUDART. M.T. 2001. Caracterização molecular de bovinos da raça Simental com base em microssatélites e RFLP. Dissertação de Mestrado em Genética e Biologia Molecular. Universidade Federal de São Carlos. São Carlos-SP, Brasil.

SYED, N.; SØRENSEN, A.P.; ANTONISE, R.; VAN DE WIEL, C.C.M.; VAN DER LINDEN, C.G.; VAN'T WESTENDE, W.P.C.; HOOFTMAN, D.A.P.; NIJS DEN, H.C.M.. \& FLAVELL, A. 2006. A detailed linkage map of lettuce based on SSAP, AFLP and NBS markers. Theoretical and Applied Genetics 112:517-527. 
TANG, X.; FREDERICK, R.D.; ZHOU, J.; HALTERMAN, D.A.; JIA, Y. \& MARTIN, G.B. 1996. Initiation of Plant disease resistance by physical interaction of AvrPo and Pto kinase. Science 274:2160-2063.

TANKSLEY, S.D.; MILLER, J.; PATERSON, A.; BERNATSKY, R. 1988. Molecular mapping of plant chromossomes. In: Gustafson, J.P. \& Appels, R. (Eds.). Chromossome Structure and Function.Springer. New York. p. 157-173.

TANKSLEY, S.D. 1993. Mapping polygenes. Annual Review Genetics 27: 205-233.

THUDI, M.; LI, Y.; JACKSON, S.A.; MAY, G.D. \& VARSHNEY, R.K. 2012. Current state-ofart of sequencing technologies for plant genomics research. Briefings in Functional Genomics 11:3-11.

TRUCO, M.J.; ANTONISE, R.; LAVELLE, D.; OCHOA, O.; KOZIK, A.; WITSENBOER, H.; FORT, S.B.; JEUKEN, M.J.W.; KESSELI, R.V.; LINDHOUT, P.; MICHELMORE, R.W. \& PELEMAN, J. 2007. A high-density, integrated genetic linkage map of lettuce (Lactuca spp.). Theoretical and Applied Genetics 115:735-746.

TRUCO, M.J.; ASHRAFI, H.; KOZIK, A.; LEEUWEN, H.V.; BOWERS, J.; CHIN WO, S.R.; STOFFEL, K.; XU, H.; HILL, T.; DEYNZE, A.V. \& MICHELMORE, R.W. 2013. An ultra-high-density, transcript-based, genetic map of lettuce. G3. Genes/genome/genetics 3: $617-631$.

TRUONG, H.T.; RAMOS, A.M.; YALCIN, F.; DE RUITER, M.; VAN DER POEL, H.J.A.; HUVENAARS, K.H.J.; HOGERS, R.C.J.; VAN ENCKEVORT, L.J.G.; JANSSEN, A.; VAN ORSOUW, N.J. \& VAN EIJK, M.J.T. 2012. Sequence-based genotyping for marker discovery and codominant scoring in germplasm and populations. Plos One 7:e37565.

TSUCHIYA, N.; YOSHIDA, K.; USUI, T. \& TSUKADA, M. 2004. Resistance tests and genetic resources for breeding Fusarium root rot resistant lettuce. Journal Japan Society Horticultural Science 73:105-113.

VAN DE WIEL, C.; ARENS, P. \& VOSMAN, B. 1999. Microsatellite retrieval in lettuce (Lactuca sativa L.). Genome 42:139-149.

VAN DER VOSSEN, E.A.; VAN DER VOORT, J.N.; KANYUKA, K.; BENDAHMANE, A.; SANDBRINK, H.; BAULCOMBE, D.C.; BAKKER, J.; STIEKEMA, W.J. \& KLEINLANKHORST, R.M. 2000. Homologues of a single resistance gene cluster in potato confer resistance to distinct pathogens: a virus and a nematode. The Plant Journal 23:567-576.

VENTURA, J.A. \& COSTA, H. 2008. Fusarium wilt caused by Fusarium oxysporum on lettuce in Espirito Santo, Brazil. Plant Disease 92: 976. 
WAYCOTT, W.; FORT, S.B.; RYDER, E.J. \& MICHELMORE, R.W. 1999. Mapping morphological genes relative to molecular markers in lettuce (Lactuca sativa L.). Heredity $82: 245-251$.

WILLIAMS, J.G.; KUBELIK, A.R.; LIVAK, K.J.; RAFALSKI, J.A. \& TINGEY, S.V. 1990. DNA polymorphism amplified by arbitrary primers are useful as genetic markers. Nucleic Acids Reseach 18: 6531-6535.

WITSENBOER, H.; MICHELMORE, R.W.; \& VOGEL, J. 1997. Identification, genetic localization, and allelic diversity of selectively amplified microsatellite polymorphic loci in lettuce and wild relatives (Lactuca spp.). Genome 40: 923-936.

WUFF, E.G.; SORENSEN, J.S.; LUBECK, M.; NIELSEN, K.F.; THARANE, U. \& TORP, J. 2010. Fusarium spp. associated with rice Bakanae: Ecology, genetic diversity, pathogenicity and toxigenicity. Environmental Microbiology 12: 649-657.

XIAO, S.; ELLWOOD, S.; CALIS, O.; PATRICK, E.; LI, T.; COLEMAN, M. \& TURNER, J. G. 2001. Broad-spectrum mildew resistance in Arabidopsis thaliana mediated by RPW8. Science 291:118-120.

XIAO, S.Y.; BROWN, S.; PATRICK, E.; BREARLEY, C. \& TURNER, J.G. 2003. Enhanced transcription of the Arabidopsis disease resistance genes RPW8.1 and RPW8.2 via a salicylic acid-dependent amplification circuit is required for hysensitive cell death. Plant Cell 15:33-45.

YAMAUCHI, N.; SHIMAZU, J.; HORIUCHI, S.; SATOU, M. \& SHIRAKAWA, T. 2001. Physiological races and vegetative compatibility groups of butterhead lettuce isolates of Fusarium oxysporum f. sp. lactucae in Japan. Journal of General Plant Pathology 67:288290.

YAMAUCHI, N.; SHIMAZU, J.; HORIUCHI, S.; SATOU, M. \& SHIRAKAWA, T. 2004. Physiological races and vegetative compatibility groups of butterhead lettuce isolates of Fusarium oxysporum f. sp. lactucae in Japan. Journal of General Plant Pathology 70:308313.

YANG, Y.; SHAH, J. \& KLESSIG, D.F. 1997. Signal perception and transduction in plant defense responses. Genes \& Development 11:1621-1639.

YOON, B.J. 2009. Hidden markov models and their applications in biological sequence analysis. Current Genomics 10:402-415.

YOUNG, N.D. 1996. QTL mapping and quantitative disease resistance in plants. Annual Review of Phytopathology 34:479-501. 
YU, Y.G.; BUSS, G.R. \& SAGHAI-MAROOF, M.A. 1996.Isolation of a superfamily of candidate disease-resistance genes in soybean based on a conserved nucleotide-binding site. Proceedings of the National Academy of Sciences USA 93:11751-11756.

ZENG, Z.B. 1993. Theorical basis for separation of multiple linked gene effects in mapping of quantitative trait loci. Procedings of the National Academic of Sciences USA 90:1097210976.

ZENG, Z.B. 1994. Precision mapping of quantitative trait loci.Genetics 136:492-496.

ZHANG, R.Z.; MURAT, F.; PONT, C.; LANGIN, T. \& SALSE, J. 2014. Paleo evolutionary plasticity of plant disease resistance genes. BMC Genomics 15:187.

ZHAO, K.; TUNG, C.; EIZENGA, G.; WRIGHT, M.; ALI, M.; PRICE, A.; NORTON, G.; ISLAM, M.; REYNOLDS, A.; MEZEY, J.; MCCLUNG, A.; BUSTAMANTE, C. \& MCCOUCH, S. 2011. Genome-wide association mapping reveals a rich genetic architecture of complex traits in Oryza sativa. Nature Communications 2:467.

ZHOU, T.; WANG, Y.; CHEN, J.Q.; ARAKI, H.; JING, Z. JIANG, K.; SHEN, J. \& TIAN, D. 2004. Molecular Genetics and Genomics 271:402-415.

ZHU, Y.; QIAN, W. \& HUA, J. 2010. Temperature modulates plant defense responses through NB-LRR proteins. Plos Pathogens 6:e1000844. 
CAPÍTULO 2

ב

Herança da resistência à murcha de fusário (Fusarium oxysporum f. sp. lactucae raça 1) na cultivar de alface 'Vanda' 


\section{Herança da resistência à murcha de fusário (Fusarium oxysporum f. sp. lactucae raça 1) na cultivar de alface 'Vanda'}

\section{RESUMO}

A murcha de fusário (causada pelo fungo Fusarium oxysporum f. sp. lactucae - FOLAC) é uma das principais doenças da alface em regiões tropicais e subtropicais. Devido às dificuldades de controle químico e cultural da murcha de fusário, a estratégia de controle mais eficiente e economicamente viável é o emprego de cultivares com resistência genética. Até o presente momento, apenas a raça 1 de FOLAC foi implicada com a murcha de fusário da alface no Brasil. Fontes de resistência genética contra a raça 1 de FOLAC foram identificadas, sendo a cultivar 'Vanda' (do grupo varietal 'crespa') um dos materais mais promissores. No entanto, ainda não existem estudos determinando o controle genético dessa resistência. A identificação de plantas híbridas resultantes de cruzamentos controlados é um dos grandes problemas enfrentados no melhoramento genético da alface. O sistema de marcadores RAPD-SCAR é uma ferramenta simples e bastante utilizada em sistemas de identificação de cultivares (fingerpriting) em diversas culturas, incluindo a alface. Três marcadores RAPD-SCAR foram desenvolvidos (SCARB11-10, SCARW15-3 e SCAR17-1) capazes de distinguir plantas híbridas, demontrando ser uma metodologia confiável e eficaz. Estudos de herança foram realizados utilizando as linhagens parentais, plantas híbridas $F_{1}$ genotipadas e as populações segregantes $\left(F_{2}\right.$ e famílias $\left.F_{3}\right)$ 
derivadas do cruzamento 'Gizele' $x$ 'Vanda'. Plantas foram inoculadas via root-diping com uma suspensão ajustada $3 \times 10^{6}$ microconídios/mL. A reação ao isolado de FOLAC raça 1 foi avaliada usando uma escala de notas variando de 1 (= sem sintomas) até 5 (= planta morta). Os resultados sugerem que a resistência a FOLAC raça 1 é determinada por um locus (monogênico) dominante, com efeitos de dosagem e penetrância incompleta. Esses dados experimentais estão em contraste com prévios estudos com isolados de FOLAC raça 1 onde herança recessiva e/ou controle poligênico foram reportados. O fato da herança da resistência na cultivar 'Vanda' ser relativamente simples, faz dessa cultivar um promissor germoplasma para uso em programas de melhoramento da alface visando incorporar resistência a FOLAC raça 1 nos diferentes segmentos varietais.

Palavras chave: Resistência, controle genético, penetrância, melhoramento. 


\begin{abstract}
Fusarium wilt (caused by fungus Fusarium oxysporum f. sp. lactucae-FOLAC) is one of the main diseases of lettuce (Lactuca sativa L.) in tropical and subtropical regions. Due to the problems of implementing effective cultural and chemical control of fusarium wilt, the most effective and economically viable strategy to control this disease has been the use of cultivars with genetic resistance. So far, only FOLAC race 1 isolates have been reported causing fusarium wilt of lettuce under Brazilian conditions. Sources resistance have been identified to FOLAC race 1 isolates with the variety Vanda (varietal group loose leaf) being one of the most promising materials. However, there is so far still no study determining the genetic control of this resistance. The identification of bona fide hybrid plants resulting from controlled crosses is one of the major challenges in lettuce breeding programs. RAPD-SCAR marker system is a simple and widely used tool in fingerpriting systems in several crops, including lettuce. Three developed RAPDSCAR markers (SCARB11-10, SCARW15-3, and SCAR17-1) were capable of distinguishing hybrid plants between the contrasting genotypes Gizele (susceptible) and Vanda. Inheritance studies were carried out using the parental lines, genotyped $F_{1}$ hybrid plants, and segregating populations $\left(\mathrm{F}_{2}\right.$ and $\mathrm{F}_{3}$ families) derived from the cross Gizele $x$ Vanda. Plants were inoculated via root dipping technique with a conidial suspension adjusted to $3 \times 10^{6}$ microconidia/mL. Reaction to one FOLAC race 1 isolate was evaluated using a disease rating scale ranging from 1 (= no symptoms) to 5 (= dead plant). The studies indicated a simple genetic control of FOLAC
\end{abstract}


race resistance in cultivar Vanda, with segregation results indicating a single gene locus with a likely combination of dosage effects and incomplete penetrance. These experimental data are in contrast to previous studies with FOLAC race 1 isolates that reported recessive inheritance and/or polygenic control. The relatively simple genetic control of FOLAC race 1 resistance in Vanda makes this variety a promising germplasm for use in lettuce breeding programs aiming to incorporated this trait in a wide array of elite lines and variety groups.

Keywords: Resistance, genetic control, penetrance, breeding, crop improvement. 


\section{INTRODUÇÃO}

A alface (Lactuca sativa L.) é a hortaliça folhosa mais importante no Brasil, possuindo expressiva importância social e econômica, sendo cultivada tanto em campo aberto quanto em sistemas protegidos e hidropônicos. No Brasil, o segmento varietal 'Crespa' é o mais importante em termos de área cultivada e volume de produção, correspondendo a aproximadamente $60 \%$ do mercado (Sala \& Costa, 2012, 2016). O segmento varietal 'Americana' ocupa aproximadamente $25 \%$ do mercado e o grupo varietal 'Lisa' e os demais segmentos ('Mimosa', 'Romana' e 'Roxa'/'Vermelha') representam em torno de $15 \%$ do total cultivado (Sala \& Costa, 2012, 2016).

No Brasil, as doenças causadas por fungos habitantes do solo são fatores limitantes para o cultivo da alface especialmente devido às práticas empregadas na cultura tais como o uso intensivo das áreas com cultivos sucessivos (Lopes et al., 2010). A murcha de fusário ou fusariose, causada pelo fungo Fusarium oxysporum f. sp. lactucae (FOLAC) é uma das principais doenças da alface em regiões tropicais e subtropicais. A variabilidade patogênica de isolados de F. oxysporum f. sp. lactucae foi agrupada em quatro raças $(1,2,3 \& 4)$ de acordo com a reação de cultivares diferenciadoras de alface (Fujinaga et al., 2003; Gilardi et al., 2016). A raça 1 do patógeno apresenta a mais ampla distribuição geográfica, sendo registrada nos seguintes países: Japão (Matuo \& Motohashi, 1967), Estados Unidos (Hubbard \& Gerik, 1993; McCreight $\boldsymbol{e t}$ al., 2005), Taiwan (Huang \& Lo, 1998), Irã (Millani et al., 1999), Portugal (Pasquali et al., 2007) e Itália (Pasquali et al., 2005, 2007). O Japão é o único país onde foi relatada a presença de três raças (1, 2 \& 3) em plantios comerciais de alface (Fujinaga et al., 2001, 2003; Yamauchi 
et al., 2004). Mais recentemente, uma nova raça (= raça 4) foi reportada ocorrendo na Holanda (Gilardi et al., 2016).

No Brasil, a murcha de fusário foi relatada inicialmente no Estado do Espírito Santo por Ventura \& Costa (2008) e, posteriormente, em outros Estados da região Sudeste (Rio de Janeiro, São Paulo e Minas Gerais) e na região Sul do Brasil (Santa Catarina, Paraná e Rio Grande do Sul) (Cabral et al., 2012). Até o presente momento, apenas isolados de FOLAC raça 1 foram relatados em associação com a doença no Brasil (Cabral et al., 2014).

Devido às dificuldades de controle químico e cultural de FOLAC (Davis et al., 2006; Lopes et al., 2010; Matheron et al., 2010; Matheron, 2015), a medida de controle mais eficiente e economicamente viável para o produtor é o uso de cultivares com resistência genética. Fontes de resistência genética de amplo espectro (i.e. efetiva contra diferentes variantes do patógeno) e com estabilidade fenotípica foram identificadas e podem ser empregadas em programas de melhoramento com objetivo de produzir cultivares de alface com resistência a isolados de FOLAC (Tsuchiya et al., 2004; Scott et al., 2010; Cabral \& Reis, 2013).

A genética de resistência contra distintos isolados de FOLAC é descrita como qualitativa ou quantitativa. Estudos de herança e o desenvolvimento de mapas genéticos para esse patógeno foram relatados utilizando populações de alface oriundas dos Estados Unidos e Japão. Os resultados indicam que a resistência para isolados da raça 2 é controlada por um gene dominante, enquanto a resposta para isolados da raça 1 é controlada quantitativamente por múltiplos fatores genéticos (McCreight et al., 2005; Aruga et al., 2012; Truco et al., comunicação pessoal).

Fontes de resistência genética contra isolados brasileiros da raça 1 também foram identificadas, sendo a cultivar 'Vanda' (do grupo varietal 'crespa') um dos materais mais promissores (Cabral \& Reis, 2013). No entanto, ainda não existem estudos determinando o 
controle genético dessa resistência quanto ao número de genes envolvidos e suas relações alélicas (dominância /recessividade).

Um problema prático enfrentado pelos programas de melhoramento genético de alface é a enorme dificuldade de identificação de plantas híbridas resultantes de cruzamentos controlados. Essa dificuldade é intensificada pela natureza autógama (cleistogâmica) da alface, que dificulta a obtenção segura de híbridos, mesmo envolvendo cruzamentos controlados, quando níveis consideráveis de autofecundação ainda podem ocorrer (Sala \& Nascimento, 2014). Nos cruzamentos intervarietais, quando os pais são fenotipicamente distintos, os descritores morfológicos são suficientes na identificação de plantas híbridas, (embora possam ser majoritariamente aplicados apenas em plantas adultas). Entretanto, quando os pais são fenotipicamente muito semelhantes, como nos cruzamentos entre acessos de um mesmo grupo varietal e/ou morfo-agronômico, há problemas para correta identificação de plantas híbridas usando apenas descritores morfológicos. Nesse aspecto, os marcadores moleculares são ferramentas poderosas para a identificação segura e precoce de plantas híbridas obtidas a partir de cruzamentos controlados (Silva et $\boldsymbol{a l}$., 2005). Os marcadores moleculares (além de acessarem diretamente o genótipo da planta e não sofrerem influência do ambiente) podem ser analisados a partir de amostras de qualquer parte da planta e em qualquer estádio de desenvolvimento. Essas características tornam os marcadores moleculares muito mais vantajosos quando comparados com análises conduzidas via descritores morfológicos.

Os marcadores derivados dos sistemas RAPD-SCAR são uma ferramenta simples e bastante utilizada em sistemas de identificação de cultivares (fingerpriting) em diversas culturas, incluindo a alface (Dziechciarkova et al., 2004). Neste contexto, visando dar suporte aos programas de melhoramento de alface, o presente trabalho teve como objetivos: desenvolver marcadores para identificação de plantas híbridas entre os dois parentais contrastantes para 
resistência ao fungo e estudar a herança da resistência a raça 1 de $F$. oxyporum f. sp. lactucae na cultivar 'Vanda'.

\section{OBJETIVOS DO CAPÍTULO}

\subsection{Objetivos Gerais}

- Caracterização da genética da resistência a um isolado de $F$. oxysporum f. sp. lactucae (FOLAC) raça 1 em populações segregantes obtidas a partir de cruzamentos entre um parental suscetível 'Gizele' (comercializada no Brasil pela empresa TopSeed) e um parental resistente 'Vanda' (Empresa Sakata Seed Sudamerica).

- Desenvolver marcadores moleculares derivados dos sistemas RAPD-SCAR capazes de identificar plantas híbridas resultantes do cruzamento intravarietal do segmento alface 'Crespa' entre as cultivares 'Gizele' e 'Vanda'.

\subsection{Objetivos Específicos}

- Determinar a herança genética associada com a resistência a raça 1 de $F$. oxysporum f. sp. lactucae na cultivar 'Vanda'

- Determinar as relações alélicas dos fatores de resistência (i.e. dominância ou recessividade)

- Investigar a ocorrência de outros fatores genéticos e outros tipos de ação gênica associados com a expressão fenotípica da resistência (ex. presença de penetrância e de efeitos de dosagem gênica).

\section{MATERIAL \& MÉTODOS}

3.1. Cruzamentos entre parentais contrastantes para resposta a isolados FOLAC raça 1 e desenvolvimento de populações segregantes para estudos de herança da resistência - 
Foram realizados cruzamentos entre o parental suscetível (PS) 'Gizele' e o parental resistente (PR) 'Vanda', que foi usado exclusivamente como progenitor masculino (= doador de pólen). As duas cultivares utilizadas como parentais são do segmento varietal do tipo 'Crespa'. As sementes resultantes dos cruzamentos (geração $F_{1}$ ) foram semeadas em bandejas e as plantas individuais produzidas foram autofecundadas, para constituir a geração $F_{2}$. Progênies $F_{3}$ foram obtidas a partir da autofecundação de plantas individuais da geração $F_{2}$. Os parentais contrastantes, os indivíduos $F_{1}$ genotipados (ver descrição abaixo) e as populações, $F_{2}$ e $F_{3}$ foram utilizadas para o estudo de herança.

\subsection{Extração de DNA genômico de linhagens parentais e indivíduos das populações} segregantes - O DNA foi extraído individualmente de cada planta das linhagens parentais e de indivíduos das populações segregantes de acordo com a metodologia de CTAB $2 \mathrm{X}$, com a incorporação de algumas modificações (Boiteux $\boldsymbol{e t}$ al., 1999). As amostras das folhas foram trituradas em cadinho de porcelana na presença de nitrogênio líquido. Em seguida, as amostras foram colocadas em tubos contendo $750 \mu \mathrm{L}$ de $\mathrm{CTAB} 2 \mathrm{X}$, colocadas em banho-maria a $65^{\circ} \mathrm{C}$ durante 10 minutos. Após esta etapa, $750 \mu \mathrm{L}$ de clorofil foram acrescentados em cada tubo e o conteúdo final foi agitado em vortex por aproximadamente 30 segundos. As amostras foram então centrifugadas por $9.000 \mathrm{rpm}$ durante 5 minutos. Os tubos foram retirados da centrifuga e $600 \mu \mathrm{L}$ do sobrenadante foram retirados e colocados em novos tubos de micro-centrífuga. Foram acrescentados $300 \mu \mathrm{L}$ de isopropanol gelado e para homogeneizar, os tubos foram suavemente agitados de forma manual. Os tubos foram posteriormente centrifugados a $12.000 \mathrm{rpm}$ durante 13 minutos. O sobrenadante foi eliminado e o pellet foi lavado, com álcool 70\%. Os tubos foram colocados na estufa a $37^{\circ} \mathrm{C}$ por 20 minutos, depois foram acrescentados $50 \mu \mathrm{L}$ de TE+RNAse e os tubos foram então acondicionados em uma geladeira. No dia seguinte, as amostras foram agitadas no vortex e os DNAs purificados foram guardados $\left(-20^{\circ} \mathrm{C}\right)$ em freezer. As quantificações 
de DNA foram feitas usando o espectrofotômetro (NanoDrop ${ }^{\circledR}$ ). Posteriormente, o DNA foi purificado usando o kit Power Clean ${ }^{\circledR}$ Pro DNA Clean-up, seguindo os procedimentos recomendados pelo fabricante (MO BIO Laboratories-Carlsbad, CA, USA). Essa etapa foi empregada porque foi verificada a presença de inibidores da PCR na maioria das amostras.

\subsection{Desenvolvimento de marcadores moleculares para identificação de plantas} híbridas no cruzamento 'Gizele' $x$ 'Vanda' com uma coleção de primers RAPD - Um total de 520 primers RAPD (série Operon OPA-01 até OPZ-20, Operon Technologies, Alameda, Califórnia, EUA) foi avaliado na busca por polimorfismos entre indivíduos contrastantes, no parental suscetível ('Gizele') e no parental resistente ('Vanda'). Duas cultivares de alface do segmento varietal americana ('Laurel' e 'Raider'), também foram incluídas (como padrões) nessas análises. As amostras de DNA quantificadas foram diluídas com TE+RNAse para uma concentração de $50 \mathrm{ng} / \mu \mathrm{L}$ e utilizadas nas reações de RAPD. A reação foi composta de $2 \mu \mathrm{L}$ de DNA genômico $(50 \mathrm{ng} / \mu \mathrm{L}), 1,25 \mu \mathrm{L}$ de tampão 10X (100 mM Tris-HCl, 500 mM KCl, pH 8.3), $0,6 \mu \mathrm{L}$ de $\mathrm{MgCl}_{2}(50 \mathrm{mM}), 0,5 \mu \mathrm{L}$ de dNTPs (2,5 $\mathrm{mM}$ cada), 0,2 $\mu \mathrm{L}$ de Taq DNA polimerase $(5 \mathrm{u} / \mu \mathrm{L}), 2 \mu \mathrm{L}$ de primer, 5,95 $\mu \mathrm{L}$ de $\mathrm{H}_{2} \mathrm{O}$ Milli-Q com volume total de 12,5 $\mu \mathrm{L}$. As amplificações foram efetuadas em um termociclador Gene Amp ${ }^{\circledR}$ PCR System 9700. O programa utilizado para amplificação dos fragmentos foi de um ciclo inicial de $94^{\circ} \mathrm{C}$ por 2 min, seguido de: 35 ciclos de $94^{\circ} \mathrm{C}$ por $30 \mathrm{seg}$ para a desnaturação, $36^{\circ} \mathrm{C}$ por 1 min para anelamento, e $72^{\circ} \mathrm{C}$ por 2 min para extensão, o ciclo final constituiu-se $68^{\circ}$ por $10 \mathrm{~min}$ e $4^{\circ} \mathrm{C}$ por tempo indeterminado ( $\infty$ ). Os produtos de PCR foram analisados em géis de agarose $(1,5 \%)$ corados com brometo de etídeo e visualizados sob luz ultravioleta, utilizando-se o marcador 1 Kb Plus DNALadder ${ }^{\circledR}$ (Invitrogen) para análise dos produtos obtidos.

3.4. Validação com amostras dos parentais e da população $F_{1}$ de marcadores RAPDSCAR - A seleção de marcadores moleculares capazes de identificar plantas híbridas entre 
'Gizele' e 'Vanda' foi conduzida em três etapas. Na primeira etapa, primers capazes de gerar amplicons polimórficos entre os dois parentais contrastantes foram selecionados para confirmação de sua estabilidade. Na segunda etapa, amplicons selecionados foram removidos do gel de agarose, purificados, clonados e sequenciados, com a finalidade de desenhar novos primers do tipo Sequence Characterized Amplified Regions (SCAR), mais específicos. Para a purificação das bandas foi utilizado o Kit Invitrogen PureLinkTM ${ }^{\circledR}$ (Quick Gel Extraction Kit $^{\circledR}$ ), seguindo as recomendações preconizadas pelo fabricante. Os novos primers desenhados foram validados nos parentais e em 30 indivíduos potencialmente representando plantas híbridas $\left(\mathrm{F}_{1}\right)$. No estudo de validação dos marcadores que foram polimórficos entre os parentais, as amplificações foram realizadas em duplicatas para confirmar a estabilidade dos resultados.

\subsection{Desenvolvimento de marcadores do tipo Sequence Characterized Amplified}

Regions (SCAR) - Para a clonagem de amplicons polimórficos foi utilizado o protocolo pGEMT Easy Vector Systems ${ }^{\circledR}$ (Promega). A ligação foi feita adicionando a microtubos: $0,5 \mu \mathrm{L}$ do vetor pGEM-T Easy ${ }^{\circledR} ; 5 \mu \mathrm{L}$ do tampão; $1 \mu \mathrm{L}$ ligase (T4 DNA); $0,5 \mu \mathrm{L}$ de água Milli-Q e $3 \mu \mathrm{L}$ do produto de PCR (bandas purificadas), com volume total de $10 \mu \mathrm{L}$ de ligação. As reações foram incubadas a $4^{\circ} \mathrm{C}$ overnight. Após esse período foram adicionados $50 \mu \mathrm{L}$ de células competentes (JM 109 High Efficiency Competent Cells, Promega) a $2 \mu \mathrm{L}$ da reação de ligação, incubando-os em gelo por 20 minutos. O choque térmico foi dado retirando os tubos do gelo e colocando em banho-maria a exatamente $42^{\circ} \mathrm{C}$ por 45 segundos. Imediatamente os tubos foram retirados e acondicionados em gelo por 2 minutos. Foram adicionados $950 \mu \mathrm{L}$ de meio LB líquido. As transformações foram incubadas (durante 1 hora e 30 minutos a $37^{\circ} \mathrm{C}$ ) em condições de constante agitação. $100 \mu \mathrm{L}$ de cada suspensão de bactérias foram espalhadas em placas de Petri contendo meio $\mathrm{LB}+$ ampicilina $(50 \mu \mathrm{g} / \mathrm{mL})$. As placas foram incubadas em estufa a $37^{\circ} \mathrm{C}$ durante 24 horas. A confirmação e seleção das bactérias transformadas foram feitas via PCR utilizando os 
iniciadores de síntese do vetor M13 (M13 reverse e forward). O DNA foi extraído das colônias selecionadas para sequenciamento dos produtos de PCR clonados (miniprep), utilizando os mesmos primers universais do vetor M13.

3.6. Sequenciamento dos amplicons clonados - O sequenciamento dos amplicons clonados foi realizado em um sequenciador ABI PRISM 3100 pertencente ao Laboratório de Análise Genômica da Embrapa Hortaliças (CNPH), utilizando o Kit ABI Prism BigDye ${ }^{\circledR}$ version 3.1 (Applied Biosystems do Brasil) e os iniciadores de síntese do vetor M13 (M13 reverse e forward). A análise da qualidade das sequências, remoção dos segmentos de baixa qualidade (Allex, 1999) e a obtenção das sequências consenso foram realizadas usando o programa SeqMan $^{\circledR}$ (Lasergene, Madison, Wisconsin-WI). As sequências foram comparadas com as disponíveis no banco de dados do GenBank, empregando algoritmo BlastN (www.ncbi.nlm.nih.gov/blast/).

\subsection{Desenho dos oligonucleotídeos e amplificação dos potenciais marcadores do tipo}

Sequence Characterized Amplified Regions (SCAR) - Pares de oligonucleotídeos foram desenhados utilizando o programa PrimerSelect ${ }^{\circledR}$ (Lasergene, Madison, Wisconsin-WI), utilizando as sequências originais dos primers RAPD com o acréscimo de 5-10 bases de acordo com as informações obtidas via sequenciamento. Os três pares primers (forward - F /reverse - R) do tipo SCAR desenhados foram os seguintes:

\footnotetext{
1 B11-10-F (5'-AGA-CCC-GTT-ACT-ACT-GGA-AGG-AA-3')

B11-10-R (5'-ACC-CGT-CCC-CGG-TAT-GAT-GAT-TCC-3')

2 W15-3-F (5'-CGG-AAC-GAC-GGA-AAT-G-3')

W15-3-R (5'-CAC-CGG-AAC-CAC-ACC-3')

$3 \begin{array}{lll}\mathbf{A 1 7 - 1 - F} & \text { (5'-GACCGCTTGTCAGCA-3') } \\ \mathbf{A 1 7 - 1 - R} & \text { (5-GACCGCTTGTGGGGTT-3') }\end{array}$
} 
As reações de amplificação foram realizadas utilizando $2 \mu \mathrm{L}$ de DNA genômico (50 $\mathrm{ng} / \mu \mathrm{L})$, em volume final de $12,5 \mu \mathrm{L}$, contendo $1,25 \mu \mathrm{L}$ de tampão $10 \mathrm{X}$ (100 mM Tris-HCl, 500 $\mathrm{mM} \mathrm{KCl}, \mathrm{pH} 8.3), 0,6 \mu \mathrm{L}$ de $\mathrm{MgCl}_{2}(50 \mathrm{mM}), 0,5 \mu \mathrm{L}$ de dNTPs (2,5 mM cada), 0,2 $\mu \mathrm{L}$ de Taq DNA polimerase $(5 \mathrm{u} / \mu \mathrm{L}), 0,3 \mu \mathrm{L}$ de cada primer $\mathrm{SCAR}, 7,35 \mu \mathrm{L}$ de $\mathrm{H}_{2} \mathrm{O}$ Milli-Q. O programa utilizado para amplificação dos fragmentos foi de um ciclo inicial de $94^{\circ} \mathrm{C}$ por 4 min, seguido de: 35 ciclos de $94^{\circ} \mathrm{C}$ por 1 min para a desnaturação, $61^{\circ} \mathrm{C}$ por 1 min para anelamento e $72^{\circ} \mathrm{C}$ por 2 min para extensão, o ciclo final constituiu-se $72^{\circ} \mathrm{C}$ por 7 min e uma etapa final de $4^{\circ} \mathrm{C} \infty$. As condições de PCR foram otimizadas em termos de temperatura de anelamento para cada primer utilizado. Os produtos de PCR foram analisados em géis de agarose $(1,5 \%)$ corados com brometo de etídeo e visualizados sob luz ultravioleta, utilizando-se o marcador 1 Kb Plus DNALadder ${ }^{\circledR}$ (Invitrogen) para análise dos produtos obtidos.

3.8. Caracterização fenotípica das linhagens parentais, híbridos $F_{1}$ e populações segregantes para resposta a resistência um isolado de FOLAC raça 1 - Plantas dos parentais PR (30 plantas) e PS (30 plantas) e das populações $F_{1}$ (30 plantas); $F_{2}$ (82 plantas) e $F_{3}$ (719 plantas) foram inoculadas com isolado CMM-3577 (Fus-209) da raça 1 de F. oxysporum f. sp. lactucae (pertencente a coleção de fungos fitopatogênicos da Embrapa Hortaliças, Brasília-DF e também depositado na coleção da "Professora Maria Menezes-Recife, Pernambuco") (Cabral \& Reis, 2013). Para estimar os genótipos dos indivíduos $F_{2}$, entre 9 e 16 plantas das diferentes progênies $\mathrm{F}_{3}$ foram avaliadas. $\mathrm{O}$ isolado do fungo foi cultivado em meio de cultura BDA-t (BDA adicionado de $50 \mathrm{ppm}$ de tetraciclina) por cinco dias. A suspensão de esporos foi ajustada para uma concentração de $3 \times 10^{6}$ microconídios $/ \mathrm{mL}$. Para produção das mudas, as sementes foram semeadas em bandejas de isopor, preenchidas com substrato esterilizado (Plantmax ${ }^{\circledR}$ ). Mudas com 30 dias após o semeio foram removidas das células e as raízes lavadas em água corrente, visando eliminar o substrato aderido às raízes. As porções apicais das raízes (aproximadamente 2 
$\mathrm{cm}$ ) foram cortadas com o auxílio de uma tesoura esterilizada e mergulhadas (por três minutos) em $50 \mathrm{~mL}$ da suspensão de esporos. Em seguida as mudas foram transplantadas para vasos de $2 \mathrm{~L}$ contendo uma mistura de argila, esterco bovino, areia e palha de arroz carbonizada e esterilizada. Posteriormente foram adicionados no colo de cada plântula $3 \mathrm{~mL}$ da suspensão de conídios. As plantas foram mantidas em casa de vegetação com temperatura do ar variando entre 25 e $35^{\circ} \mathrm{C}$ e fotoperíodo de 12 horas e turnos de rega regulares (um pela manhã e outro no final da tarde). A irrigação foi suprimida no dia da inoculação visando evitar perda do inóculo por lixiviação.

\subsection{Avaliação da resposta dos materiais genéticos de alface ao isolado de FOLAC raça}

1 e análises dos padrões de segregação para resistência - A avaliação foi efetuada aos 20 dias após a inoculação usando uma escala de notas, adaptada de Santos (1996), variando de 1 a 5 , sendo a nota $\mathbf{1}$ = plantas sem sintomas; nota $\mathbf{2}=$ plantas sem sintomas de murcha ou amarelecimento, mas com escurecimento vascular; nota $\mathbf{3}=$ plantas com escurecimento vascular intenso e com início de murcha ou amarelecimento foliar; nota $\mathbf{4}$ = plantas com murcha intensa, associada com amarelecimento e necrose foliar; nota $\mathbf{5}=$ plantas mortas. As plantas foram classificadas (com base nas notas recebidas) como resistentes $(\mathrm{R} \leq 2)$ ou suscetíveis $(\mathrm{S}>2)$. $\mathrm{O}$ padrão de segregação de indivíduos resistentes e suscetíveis foi observado para cada uma das gerações/populações e a adequação a razões mendelianas foi conduzida utilizando o teste do quiquadrado (Schuster \& Cruz, 2004; Ramalho et al., 2008).

3.10. Validação dos marcadores moleculares entre os parentais contrastantes - Os marcadores moleculares gerados pelos diferentes primers RAPD e SCAR foram analisados quanto à presença de bandas (amplicons) polimórficas entre os dois parentais contrastantes. Foi observada a presença ou ausência de bandas informativas (marcadores dominantes) ou a presença de bandas com variação no tamanho (sugerindo a presença de INDELs - inserções e/ou 
deleções). Foram consideradas bandas informativas somente aquelas com alta intensidade e estabilidade.

3.11. Emprego da estratégia de Bulked segregant analysis (BSA) para verificar potencial ligação com o(s) fator(es) de resistência a FOLAC raça 1 dos marcadores polimórficos entre os parentais contrastantes - Foram estabelecidos dois grupos (bulks) de DNA extraído de sete genótipos resistentes e sete indivíduos suscetiveis da geração $\mathrm{F}_{2}$ como descrito por Michelmore et al. (1991). A confirmação da presença de polimorfismos entre os dois bulks foi feita com marcadores RAPD e SCAR polimórficos descritos anteriormente.

\section{RESULTADOS}

\subsection{Desenvolvimento de marcadores moleculares para identificação de plantas} híbridas entre 'Gizele' e 'Vanda' - Foi utilizado em uma triagem inicial um total de 512 iniciadores RAPD (Figura 2-1). Destes, apenas 13 (OPA-01, OPA-17, OPB-03, OPB-11, OPC04, OPL-12, OPK-03, OPO-17, OPS-01, OPS-08, OPT-14, OPS-06 e OPW-15) foram selecionados por se apresentarem polimórficos. Análises adicionais indicaram que somente três desses marcadores apresentavam polimorfismos estáveis com o DNA genômico extraído dos dois parentais contrastantes para FOLAC raça 1 ('Gizele' e 'Vanda'). Esses três iniciadores RAPD que mantiveram a estabilidade dos amplicons polimórficos foram convertidos para três marcadores do tipo SCAR (códigos: SCARB11-10, SCARW15-3 e SCAR17-1). Análises adicionais confirmaram que estes marcadores SCAR permitem uma inequívoca distinção de plantas híbridas versus plantas autofecundadas (Figura 2-2).

4.2. Padrão de segregação de resistência para FOLAC raça 1 - A severidade de doença das progênies $F_{2}$ e $F_{3}$ derivadas do cruzamento entre uma cultivar resistente e uma suscetível foi utilizada para entender os fatores de resistência para FOLAC raça 1. O padrão de resistência entre 
os parentais foi relatado anteriormente por Cabral et al. (2013). O parental 'Vanda'apresentou $100 \%$ de plantas resistentes e a geração $F_{1}$ apresentou $83,33 \%$ das plantas com resposta do tipo resistente. O parental 'Gizele' apresentou 100\% de plantas mortas. A severidade da doença na progênie de 82 indivíduos da população $F_{2}$ foi distribuída da seguinte forma: 13 plantas, nota 5.0; e 69 plantas, nota 1 e/ou 2. De acordo com distribuição da taxa da severidade da doença, observou-se um padrão de segregação na geração $F_{2}$ com um bom ajuste à proporção 3:1 (resistente vs. suscetível) de acordo com o teste do qui-quadrado $\left(\chi^{2}\right)(\mathrm{p}>0,05)$, já que o valor calculado foi maior que o tabelado com grau de liberdade (GL) de 1 e probabilidade (P) de 0,05 (Tabela 2-1).

Tabela 2-1. Análise das respostas de plantas de alface (Lactuca sativa L.) a um isolado de Fusarium oxysporum $\mathrm{f}$. sp. lactucae raça 1 nas gerações $\mathrm{F}_{1} \mathrm{e} \mathrm{F}_{2}$ obtidas do cruzamento entre os parentais 'Gizele' (suscetível) $x$ 'Vanda' (resistente) e ajuste dos dados dos padrões de segregação para um modelo de 3:1 de acordo o teste de do qui-quadrado $\left(x^{2}\right)$.

\begin{tabular}{|c|c|c|c|c|c|c|c|}
\hline \multicolumn{2}{|c|}{$\begin{array}{c}\text { Parentais e } \\
\text { gerações }\end{array}$} & \multicolumn{2}{|c|}{ Número de plantas avaliadas } & $\begin{array}{c}\text { Padrão } \\
\text { esperado } \\
\text { (R:S) }\end{array}$ & $\begin{array}{c}\chi^{2} \\
\text { tabelado }\end{array}$ & $\begin{array}{c}\chi^{2} \\
\text { calculado }\end{array}$ \\
\cline { 2 - 7 } & Total & $\begin{array}{c}\text { Plantas } \\
\text { R }\end{array}$ & Plantas S & & \\
\hline 'Gizele' & $\mathrm{P}_{1}$ & 30 & 0 & 30 & $1: 00$ & - & - \\
\hline 'Vanda' & $\mathrm{P}_{2}$ & 30 & 30 & 0 & $0: 01$ & - & - \\
\hline $\mathrm{P}_{1} x \mathrm{P}_{2}$ & $\mathrm{~F}_{1}$ & 30 & 25 & 5 & $1: 00$ & - & - \\
\hline $\mathrm{F}_{1} x \mathrm{~F}_{1}$ & $\mathrm{~F}_{2}$ & 82 & 69 & 13 & $3: 01$ & 3,84 & $3,65^{*}$ \\
\hline
\end{tabular}

* Valor encontrado para $\mathrm{GL}=1$ e $\mathrm{P}=0,05$.

Devido ao fato do isolado de FOLAC raça 1 induzir a morte das plantas $\mathrm{F}_{2}$ suscetíveis, apenas indivíduos resistentes (ou potenciais escapes) puderam gerar progênies $F_{3}$. Para progênies $F_{3}$ oriundas apenas de indivíduos resistentes, observou-se 1/3 das progênies obtidas de indivíduos homozigotos $\mathrm{RR}(\approx 23$ famílias $)$ e $2 / 3$ de indivíduos heterozigotos $\operatorname{Rr}(\approx 46$ famílias $)$. 


\subsection{Bulked segregant analysis (BSA) para verificar potencial ligação com o(s) fator(es)}

de resistência a FOLAC raça 1 dos marcadores polimórificos entre os parentais contrastantes - Todos os três iniciadores que mantiveram a estabilidade dos amplicons polimórficos (SCARB11-10, SCARW15-3 e SCARA17-1) foram avaliados com DNA de dois grupos (bulks) (Michelmore et al., 1991). No entanto, nenhum desses marcadores mostrou-se estar em ligação com o fenótipo de resistência.

\section{DISCUSSÃO}

Para a identificação de híbridos entre as cultivares 'Gizele' e 'Vanda', foi utilizado, em uma triagem inicial, um total de 512 iniciadores RAPD. Destes, apenas 13 foram selecionados por se apresentaram polimórficos e, após exaustivas análises, somente três destes confirmaram os polimorfismos entre os parentais contrastantes para FOLAC raça 1. A diversidade genética de alface cultivada em nível molecular foi investigada por vários grupos de pesquisa com diferentes sistemas de marcadores com resultados variáveis em termos dos níveis de polimorfismos observados (Kesseli \& Michelmore 1986; Kesseli et al. 1991; Hu et al., 2005; Simko, 2009; van Treuren \& van Hintum, 2009). A quantidade relativamente baixa de polimorfismos obtidos no presente estudo se deve, provavelmente, ao fato de que a espécie $L$. sativa tem uma base genética estreita (Kesseli \& Michelmore, 1986; Kesseli et al., 1991; Hu et al., 2005; Simko, 2009; van Treuren \& van Hintum, 2009) que foi agravado ainda mais pelo fato de que os dois parentais constratantes serem pertencentes a um mesmo grupo varietal ou morfo-agronômico. Apesar de todas as limitações, amplicons polimórficos estáveis foram identificados entre os parentais constrastantes e apenas plantas genotipadas como híbridas foram utilizadas no estudo subsequente de herança da resistência. Como esperado, os indivíduos $F_{1}$ empregados para a 
obtenção das populações $F_{2}$ segregantes apresentaram um alelo (= banda ou amplicon) oriundo do parental resistente e outro alelo oriundo do parental suscetível (Figura 2-2).

Na cultura da alface, há uma dificuldade inerente na identificação segura e precoce dos híbridos, pois algumas plantas da progênie podem ser originadas de autofecundação da planta mãe, reforçando a importância do uso de marcadores como ferramenta auxiliar para o trabalho dos melhoristas e geneticistas. O emprego de marcadores moleculares com uma alternativa viável para confirmação dos cruzamentos em alface foi relatado por vários autores. Segundo D'Andrea et al. (2008) a obtenção de híbridos de alface resultantes de cruzamentos interespecíficos foi confirmada pela análise de bandas informativas utilizando o primer específico RAPD (OPT-06). Da mesma forma, Uwimana et al. (2012a,b) identificaram híbridos de alface resultantes do cruzamento interespecífico entre $L$. sativa e $L$. serriola, por meio de marcadores SSR.

Os genitores contrastantes para a resposta a isolados de FOLAC raça 1 foram escolhidos em virtude do seu potencial agronômico e também características de interesse, visando obter populações segregantes com maior frequência de indivíduos com alta produtividade, ciclo precoce, adaptação às condições tropicais de cultivo, rusticidade e resistência a doenças. Os três marcadores SCAR desenvolvidos para distinguir plantas híbridas mostraram-se excelentes ferramentas para verificar a ocorrência da hibridização, demonstrando ser uma metodologia confiável e eficaz, que permite sua utilização em estágios iniciais do desenvolvimento das supostas plantas hibrídas. A estratégia de bulked segregant analysis (BSA) é frequentemente utilizada no melhoramento genético da alface para identificar marcadores associados com fenótipos contrastantes (Michelmore et al., 1991). No entanto, no presente trabalho, apesar dos marcadores obtidos distiguiram de maneira estável os parentais contrastantes, nenhum deles mostrou uma forte ligação com o fenótipo de resistência a FOLAC raça 1. 
Nas condições experimentais descritas no presente trabalho, as plantas foram submetidas a um método de inoculação drástico que consistiu de uma imersão do sistema radicular uma suspensão com alta concentração de esporos (3 $\times 10^{6}$ microconídios/mL) após injúria mecânica (cortes com tesoura aproximadamente $2 \mathrm{~cm}$ acima da extremidade da raiz). Além disso, para acompanhamento do desenvolvimento dos sintomas, as plantas foram expostas a temperaturas do ar variando entre $25{ }^{\circ} \mathrm{C}$ a $35{ }^{\circ} \mathrm{C}$. Essas condições experimentais podem ter contribuído para aumentar a frequência de plantas suscetíveis, inibindo a plena expressão do(s) fator(es) de resistência. De fato, em sistemas de seleção de plantas resistentes quando a inoculação com o patógeno é requerida, a expressão dos genes alvos é altamente variável as condições ambientais (Jiang, 2013). A temperatura, por exemplo, é conhecida por modular a expressão da resistência em diferentes interações entre patógenos - hospedeiros. Temperaturas do solo e do ar elevadas podem, muitas vezes, inibir a expressão da resistência ou intensificar reações de suscetibilidade (Schoeneweiss, 1975). No entanto, a base genética e molecular da sensibilidade à temperatura dos genes R é ainda pouco caracterizada (Zhu et al., 2010). Por exemplo, plantas de Arabidopsis se mostraram mais suscetíveis à Pseudomas syringae pv. tomato a $28{ }^{\circ} \mathrm{C}$ do que a $22{ }^{\circ} \mathrm{C}$ (Wang et al., 2009). A resistência ao Tobacco mosaic virus (TMV) conferida pelo gene $N$ em acessos de fumo é eficaz a $22^{\circ} \mathrm{C}$, mas não se expressa a $30{ }^{\circ} \mathrm{C}$ (Whitham et al., 1996). Resistência aos nematóides das galhas conferida pelo gene $M i$ em tomate é inativada em temperaturas de solo acima de $28^{\circ} \mathrm{C}$ (Hwang et al., 2000).

O fenômeno genético de resistência 'parcial' devido aos fenômenos de semi-dominância e penetrância incompleta (i.e. percentagem de indivíduos de uma população com um dado genótipo que expressa o fenótipo correspondente) também parece estar envolvido no patossistema alface FOLAC raça 1. Proporções variáveis de plantas doentes foram encontradas em progênies $\mathrm{F}_{3}$ de plantas $\mathrm{F}_{2}$ caracterizadas como resistentes. A penetrância é afetada, entre outros fatores, pela 
interação entre genótipo do hospedeiro, isolado do patógeno, concentração do inóculo, idade das mudas e temperatura do solo e do ar. Com uma tendência geral, um aumento na concentração (pressão) do inóculo também induz uma redução nos níveis de penetrância, ou seja, um aumento na incidência de plantas expressando sintomas da doença.

Outro ponto a ser investigado é o efeito de dosagem do(s) fator(es) de resistência presentes na cultivar 'Vanda'. Neste cenário, plantas heterozigotas (i.e. com apenas uma dose do fator de resistência) se mostraram mais sensíveis aos isolados de FOLAC raça 1 quando comparadas com plantas homozigotas. $\mathrm{O}$ efeito de dosagem gênica já foi evidenciado em estudos realizados no patossistema $F$. oxyporum f. sp. lycopersici em tomate (Alon et al., 1974).

Estudos de herança genética da resistência à raça 2 de FOLAC em alface também foram realizados e um gene semi-dominante (denominado $R R D 2$ ) foi caracterizado controlando essa característica (Aruga et al., 2012). Neste trabalho, um mapa de ligação foi construído utilizando plantas $\mathrm{F}_{2}$ do cruzamento entre 'VP1013' e 'Patriot' e o locus RRD2 foi caracterizado. O locus RRD2 está posicionado entre os marcadores WF11-12 e WF09-23 no grupo de ligação 2, enquanto o marcador WF25-42 foi intimamente associado com alelos de suscetibilidade. Aruga et al. (2012) assumiram que a resistência a raça 2 de FOLAC apresentava um controle mediado pela ação de um único locus semi-dominante, pois as taxas de segregação esperadas para marcadores dominantes para uma população $F_{2}$ foram na proporção esperada 1:2:1 (resistente: intermediário: suscetível). No entanto, os autores sugerem a presença de efeitos associados com loci menores que também podem contribuir para algumas modificações no padrão de segregação.

McCreight et al. (2005) identificaram fontes de resistência a isolados norte-americanos de FOLAC raça 1 nas cultivares 'Salinas', 'Salinas 88' e 'Costa Rica No.4'. Por sua vez, a cultivar 'Vanguard' se mostrou altamente suscetível. Análises dos padrões de segregação em populações $F_{1}$ e $F_{2}$ indicaram que a herança da resistência em 'Salinas' e 'Costa Rica No.4' é 
predominantemente controlada por múltiplos fatores recessivos. A resistência contra FOLAC raça 1 foi mapeada em duas populações. Na população derivada do cruzamento [('Valmaine' $x$ 'Salinas 88') $x$ 'Salinas'] foram detectados quatro QTLs de resistência nos grupos de ligação LG1, LG2 e LG7. Os alelos de resistência localizados nos grupos de ligação LG1 e LG2 foram originados da cultivar 'Valmaine', enquanto o alelo presente no LG7 foi foi originado da cultivar 'Salinas' (Michelmore et al., 2010). Por sua vez, quatro QTLs associados com a resistência nos grupos de ligação LgG1, LG4 e LG8 foram detectados na análise de 112 indivíduos $\mathrm{F}_{2}$ derivados do cruzamento entre 'Red Tide' $x$ 'Lolla Rosa' (Truco et al., comunicação pessoal). Esses dados de experimentos prévios com isolados de FOLAC raça 1 indicando a presença de distintos fatores em todas as fontes de resistência estudas até o presente momento estão em contraste com os obtidos no cruzamento entre 'Gizele' $x$ 'Vanda'. Além disso, é importante realçar o fato da herança da resistência na cultivar 'Vanda' ser primariamente determinada por um locus dominante monogênico, característica que faz dessa cultivar um promissor germoplasma para uso em programas de melhoramento da alface visando resistência a isolados de FOLAC raça 1. 


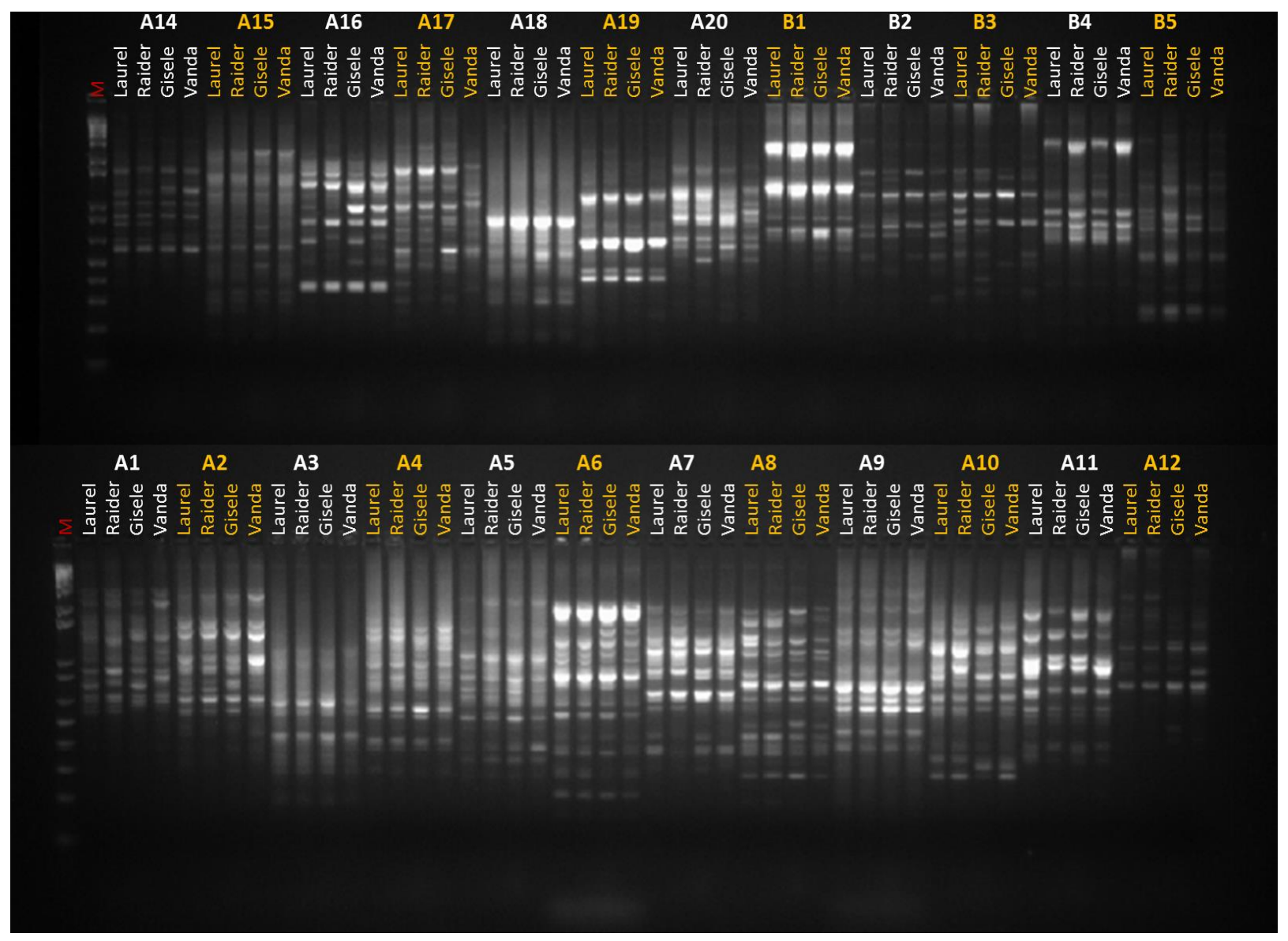

Figura 2-1. Perfil de amplicons gerados com um subconjunto de primers RAPD dos grupos OPA e OP-B (Operon) usando como molde o DNA genômico dos genitores de alface contrastantes para resistência a Fusarium oxysporum f. sp. lactucae (FOLAC) raça 1 ['Vanda', resistente e 'Gizele', suscetivel]. Duas cultivares de alface do segmento varietal Americana ('Laurel' e 'Raider'), também foram incluídas (como padrões) nessas análises. O código ' $M$ ' indica a linha do marcador de peso molecular $1 \mathrm{~kb}$ plus DNA ladder(Invitrogen). 


\section{V V G $\begin{array}{lllllllllllll}1 & 2 & 3 & 5 & 6 & 8 & 9 & 12 & 11 & 17\end{array}$}
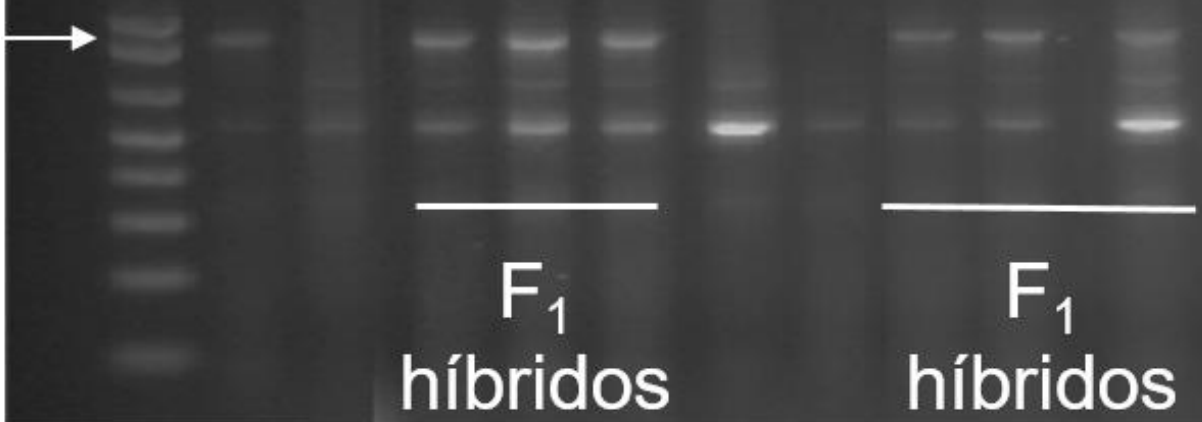

\section{Q V: Doadora de pólen (Parental masculino) \\ O’ G: Parental feminino}

Figura 2-2. Perfil de amplicons obtido com o par de primers SCAR OPW-15-3 para os genitores contrastantes para resistência a Fusarium oxysporum f. sp. lactucae (FOLAC) raça 1 ['Vanda' (V), resistente e 'Gizele' (G), suscetivel]. A eletrofore em gel de agarose (1,2\%) ilustra o padrão de bandas para ' $\mathrm{V}$ ' e ' $\mathrm{G}$ ' e para 11 plantas potencialmente de natureza híbrida $\mathrm{F}_{1}$ (códigos 1, 2, 3, $5,6,8,9,12,11 \& 17$ ) obtidas de cruzamentos controlados entre ' $G$ ' $x$ ' $V$ '. O código ' $M$ ' indica a linha do marcador de peso molecular $1 \mathrm{~kb}$ plus DNA ladder (Invitrogen). A seta aponta uma banda polimórfica informativa (originária de 'Vanda') que foi utilizada para distinguir plantas verdadeiramente de origem híbrida $\mathrm{F}_{1}$ (ex. as assinaladas com barras) de plantas de 'Gizele' autofecundadas (ex. 5, 6, 11 \& 17), quando empregando a cultivar 'Vanda' como doadora de pólen e 'Gizele' como receptora de pólen. 


\section{REFERÊNCIAS BIBLIOGRÁFICAS}

ALLEX, C.F. 1999. Computational methods for fast and accurate DNA fragment assembly. Ph.D. Thesis. University of Wisconsin.Wisconsin, Madison.

ALON, H.; KATAN, J. \& KEDAR, N. 1974. Factors affecting penetrance of resistance to Fusarium oxysporum f. sp. lycopersici in tomato. Phytopathology 64:455-461.

ARUGA, D.; TSUCHIYA, N.; MATSUMURA, H.; MATSUMOTO, E. \& HAYASHIDA, N. 2012. Analysis of RAPD and AFLP markers linked to resistance to Fusarium oxysporum $\mathrm{f}$. sp. lactucae race 2 in lettuce (Lactuca sativa L.). Euphytica 187:1-9.

BOITEUX, L.S.; FONSECA, M.E.N. \& SIMON, P.W. 1999. Effects of plant tissue and DNA purification method on randomly amplified polymorphic DNA based genetic fingerprinting analyses in carrot. Journal of the American Society for Horticultural Science 124:32-38.

CABRAL, C.S. 2012. Caracterização de isolados de Fusarium oxysporum f. sp. lactucae das Regiões Sul e Sudeste do Brasil e identificação de acessos de alface resistentes. Dissertação de Mestrado em Fitopatologia. Universidade Federal Rural de Pernambuco. Recife, Brasil.

CABRAL, C.S. \& REIS, A. 2013. Screening of lettuce accessions for resistance to Fusarium oxysporum f. sp. lactucae race 1. Tropical Plant Pathology 38:272-281.

CABRAL, C.S.; BRUNELLI, K.R.; COSTA, H.; FONSECA, M.E.N.; BOITEUX, L.S. \& REIS, A. 2014. Identification of Fusarium oxysporum f. sp. lactucae race 1 as the causal agent of lettuce wilt in Brazil. Tropical Plant Pathology 39:197-202.

D'ANDREA, L.; FELBER, F. \& GUADAGNUOLO, R. 2008. Hybridization rates between lettuce (Lactuca sativa) and its wild relative ( $L$. serriola) under field conditions. Environmental Biosafety Research 7:61-71.

DAVIS, R.M.; COLYER, P.D.; ROTHROCK, C.S \& KOCHMAN, J.R. 2006. Fusarium wilt of cotton: population diversity and implications for management. Plant Disease 90:692-703.

DZIECHCIARKOVA, M; LEBEDA, A; DOLEZALOVA, I \& ASTLEY, D. 2004. Characterization of Lactuca spp. germplasm by protein and molecular markers - a review. Plant Soil and Environment 50:47-58.

FUJINAGA, M.; OGISO, H.; TSUCHIYA, N. \& SAITO, H. 2001. Physiological specialization of Fusarium oxysporum oxysporum f. sp. lactucae, a causal organism of fusarium root rot of crip head lettuce. Journal of General Plant Pathology 67:205-206. 
FUJINAGA, M.; OGISO, H.; TSUCHIYA, N. \& SAITO, H. 2003. Race 3, a new race of Fusarium oxysporum f. sp. lactucae determined by a differencial system with commercial cultivars. Journal of General Plant Pathology 69:23-28.

GILARDI, G.; FRANCO ORTEGA, S.; RIJSWICK, P.C.J.; ORTU, G.; GULLINO, M.L. \& GARIBALDI, A. 2016. A new race of Fusarium oxysporum f. sp. lactucae of lettuce. Plant Pathology.

HU, J.; OCHOA, O.E.; TRUCO, M.J. \& VICK, B.A. 2005. Application of the TRAP technique to lettuce (Lactuca sativa L.) genotyping. Euphytica 144:225-235.

HUANG, J.H. \& LO, C.T. 1998. Wilt of lettuce caused by Fusarium oxysporum in Taiwan. Plant Pathology Bulletin 7:150-153.

HUBBARD, J.C. \& GERIK, J.S. 1993. A new disease of lettuce incited by Fusarium oxysporum f. sp. lactucum forma specialis nov. Plant Disease 77:750-754.

HWANG, C.F.; BHAKTA, A.V.; TRUESDELL, G.M.; PUDLO, W.M. \& WILLIAMSON, V.M. 2000. Evidence for a role of the $\mathrm{N}$ terminus and leucine-rich repeat region of the Mi gene product in regulation of localized cell death. Plant Cell 12:1319-1329.

JIANG, G-L. 2013. Molecular markers and marker-assisted breeding in plants. Plant Breeding from Laboratories to Fields $45-83$.

KESSELI, R.V. \& MICHELMORE, R.W. 1986. Journal of Heredity 77:324-331.

KESSELI, R.; OCHOA, O. \& MICHELMORE, R.W. 1991. Variation at RFLP loci in Lactuca spp. and origin of cultivated lettuce (L. sativa). Genome 34: 430-436.

LOPES, C.A.; QUEZADO-DUVAL, A. \& REIS, A. 2010. Doenças da Alface. Brasília: Embrapa Hortaliças. Brasília-DF.

MATHERON, M.E. \& PORCHAS, M. 2010. Evaluation of soil solarization and flooding as management tools for Fusarium wilt of lettuce. Plant Disease 94:1323-1328.

MATHERON, M.E. 2015. Biology and management of Fusarium wilt of lettuce.

MATUO, T. \& MOTOHASHI, S. 1967. On Fusarium oxysporum f. sp. lactucae n.f. causing root of lettuce. Transactions of Mycological Society of Japan 8:13-15.

MCCREIGHT, J.D.; MATHERON, M.E.; TICKES, B.R. \& PLANTTS, B. 2005. Fusarium wilt race 1 on lettuce. HortScience 40:529-531. 
MICHELMORE, R.W. 2010. Genetic variation in lettuce. California leafy greens research program,calgreens.org/control/uploads/Michelmore_Variation_report_2009-

2010_final_(2)1.pdf

MICHELMORE, R.W.; PARAN, I. \& KESSELI, R.V. 1991. Identification of markers linked to disease-resistance genes by bulked segregant analysis: a rapid method to detect markers in specific genomic regions by using segregating populations. Proceedings of the National Academy of Sciences USA 88:9828-9832.

MICHELMORE, R.W.; CHRISTOPOULOU, M. \& CALDWELL, K.S. 2013. Impacts of resistance gene genetics, function, and evolution on a durable future. Annual Review of Phytopathology 51:291-319.

MILLANI, M.J.; EREBARIAN, H.R. \& ALIZADEH, A. 1999. Occurrence of fusarium wilt of lettuce in Shahr- Ray, Varamim and Karaj areas. Journal of Plant Pathology 35:121.

PASQUALI, M.; DEMATHEIS, F.; GILARDI, G.; GULLINO, M.L. \& GARIBALDI, A. 2005. Vegetative compatibility groups of Fusarium oxysporum f. sp. lactucae from lettuce. Plant Disease 89:237-240.

PASQUALI, M.; DEMATHEIS, F.; GULLINO, M.L. \& GARIBALDI, A. 2007. Identification of race 1 of Fusarium oxysporum f. sp. lactucae on lettuce by inter-retrotranposon sequencechacarterized amplified region technique. Phytopathology 97:987-996.

RAMALHO, M.A.P.; SANTOS, J.B. \& PINTO, C.A.B. 2008. Genética na Agropecuária. 4 ed. UFLA. Lavras.

SALA, F.C. \& COSTA, C.D. 2012. Retrospectiva e tendência da alfacicultura brasileira. Horticultura brasileira 30: 187-194.

SALA, F.C. \& NASCIMENTO, W.M. 2014. Produção de sementes de alface. In: Nascimento, W.M. (ed.). Produção de Sementes de Hortaliças. Embrapa. Brasília, DF.

SALA, F.C. \& COSTA, C.P 2016. Melhoramento de alface. In: Nick, C. \& Bórem, A. Melhoramento de Hortaliças. (eds.).UFV.Viçoca, MG.

SANTOS, J.R.M. 1996. Methodology for screening tomato to Fusarium wilt, Verticillium wilt, gray leaf spot, early blight, and Septoria leaf spot. In: Proceedings of the International Symposium on Tropical Tomato Diseases. Recife PE, Brazil. p. 164-166.

SCHOENEWEISS, D.F. 1975. Predisposition, stress, and plant disease. Annual review of phytopathology 13: 193-211. 
SCHUSTER, I. \& CRUZ, C.D. 2004. Estatística Genômica Aplicada a Populações Derivadas de Cruzamentos Controlados. UFV. Viçosa, MG.

SCOTT, J.C.; KIRKPATRICK, S.C. \& GORDON, T.R. 2010. Variation in susceptibility of lettuce cultivars to Fusarium wilt caused by Fusarium oxysporum f. sp. lactucae. Plant Pathology 59:139-146.

SILVA, M.P.; AMARAL, JR. A.T.; PEREIRA, M.G.; RODRIGUES, R.; DAHER, R.F. \& POSSE, S.C.P. 2005. Diversidade genética e identificação de híbridos por marcadores RAPD em feijão-de-vagem. Acta Scientiarum Agronomy 27:531-535.

SIMKO, I. 2009. Development of EST-SSR markers for the study of population structure in lettuce (Lactuca sativa L.). Journal of Heredity 100:256-262.

TSUCHIYA, N.; YOSHIDA, K.; USUI, T. \& TSUKADA, M. 2004. Resistance tests and genetic resources for breeding Fusarium root rot resistant lettuce. Journal of the Japanese Society Horticultural Science 73:105-113.

UWIMANA, B.; D’ANDREA, L.; FELBER, F.; HOOFTMAN, D.A.P.; DEN NIJS, H.C.M.; SMULDERS, M.J.M.; VISSER, R.G.F. \& VAN DE WIEL, C.C.M. 2012a. A Bayesian analysis of gene flow from crops to their wild relatives: cultivated (Lactuca sativa L.) and prickly lettuce (L. serriola L.), and the recent expansion of L. serriola in Europe. Molecular Ecology 21:2640-2654.

UWIMANA, B.; SMULDERS, M.J.M.; HOOFTMAN, D.A.P.; HARTMAN, Y.; VAN TIENDEREN, P.H.; JANSEN, J.; MCHALE, L.K.; MICHELMORE, R.W.; VISSER, R.G.F. \& VAN DE WIEL, C.C.M. 2012b. Crop to wild introgression in lettuce: following the fate of crop genome segments in backcross populations. BMC Plant Biology 12:43.

VAN TREUREN, R. \& VAN HINTUM, T.J.L. 2009. Comparison of anonymous and targeted molecular markers for the estimation of genetic diversity in ex situ conserved Lactuca. Theoretical and Applied Genetics 119:1265-1279.

VENTURA, J.A. \& COSTA, H. 2008. Fusarium wilt caused by Fusarium oxysporum on lettuce in Espirito Santo, Brazil. Plant Disease 92: 976.

WANG, Y.; BAO, Z.; ZHU, Y. \& HUA, J. 2009. Analysis of temperature modulation of plant defense against biotrophic microbes. Molecular Plant-Microbe Interactions 22:498-506.

WHITHAM, S.; MCCORMICK, S. \& BAKER, B. 1996. The N gene of tobacco confers resistance to tobacco mosaic virus in transgenic tomato. Procedings of the National Academy of Sciences 93:8776-8781. 
YAMAUCHI, N.; SHIMAZU, J.; HORIUCHI, S.; SATOU, M. \& SHIRAKAWA, T. 2004. Physiological races and vegetative compatibility groups of butterhead lettuce isolates of Fusarium oxysporum f. sp. lactucae in Japan. Journal of General Plant Pathology 70:308313.

ZHU, Y.; QIAN, W. \& HUA, J. 2010. Temperature modulates plant defense responses through NB-LRR proteins. Plos Pathogens 6: e1000844. 


\section{CAPÍTULO 3}

Plataforma de marcadores DR analogs derivados de clusters gênicos do genoma da alface: Aplicação na localização de fatores de resistência a Fusarium oxysporum f. sp. lactucae (raça 1). 


\section{Plataforma de marcadores DR analogs derivados de clusters gênicos do genoma da alface: Aplicação na localização de fatores de resistência a Fusarium oxysporum f. sp. lactucae (raça 1)}

\section{RESUMO}

A murcha de fusário, causada por diferentes raças do fungo Fusarium oxysporum f. sp. lactucae (FOLAC), é um dos mais importantes problemas fitossanitários da cultura da alface (Lactuca sativa L.), acarretando perdas na produção em diferentes regiões do mundo. A seleção assistida por marcadores (MAS) poderia ser explorada como uma ferramenta acoplada ao melhoramento convencional, visando facilitar a obtenção de cultivares resistentes a diferentes raças de FOLAC. Em relação à resistência a FOLAC raça 1 , estudos de herança indicaram um controle monogênico dominante e com penetrância incompleta na cultivar 'Vanda'. No entanto, marcadores moleculares ligados a fatores de resistência ao FOLAC raça 1 derivados dessa cultivar ainda não estão disponíveis impedindo a determinação de sua localização cromossômica. O objetivo do presente trabalho foi estabelecer uma coleção de primers visando identificar marcadores ligados com a resistência a FOLAC raça 1. A plataforma consiste de uma coleção de oligonucleotídeos (primers) que foram selecionados para anelar em regiões distribuídas nos nove cromossomos da alface, de acordo com as informações disponíveis no Compositae Genome Project Database. A maioria dos genes de resistência a doenças em alface está localizada em cinco grandes agrupamentos físicos ou clusters (major resistance clusters - MRCs). Desta forma, foi explorado inicialmente um subconjunto de 98 pares de primers que anelam em regiões dispersas em cinco principais MRCs do genoma da alface localizados nos cromossomos/grupos de ligação 1, 2, 4, 7 \& 8. Marcadores moleculares do tipo Disease resistance analogs (DR-analogs), SCAR (Sequence Characterized Amplified Regions), CAPS (Cleaved Amplified Polymorphic Sequence) 
e microssatélites foram avaliados para polimorfismos entre as cultivares 'Gizele' (suscetível) e 'Vanda' (resistente) e em uma população $\mathrm{F}_{2}(\mathrm{n}=82)$, resultante do cruzamento entre 'Vanda' (resistente a FOLAC raça 1) e 'Gizele' (suscetível). Marcadores DR analog polimórficos entre as cultivares contrastantes foram avaliados para verificar ligação com o fenótipo de resistência empregando populações de mapeamento $F_{2}(n=82)$ e $F_{3}$ derivadas do cruzamento entre 'Gizele' $x$ 'Vanda' após bioensaios com inoculação controlada do fungo. No entanto, dentro do subgrupo analisado, não foram obtidas evidências inequívocas de ligação genética com os fatores de resistência a FOLAC raça 1, sugerindo que este(s) fator(es) não se localizam nos MRCs dos cromossomos/grupos de ligação 1, 2, 4, 7 \& 8. De qualquer forma, essa coleção de marcadores moleculares servirá como um banco de dados para programas de melhoramento especialmente em estudos de variabilidade genética de genótipos e na busca por marcadores ligados a distintas características de interesse no melhoramento da alface. A identificação de vários marcadores moleculares dentro de diversas famílias de genes de resistência no genoma de alface é importante e podem ser utilizados em sistemas de caracterização (fingerpriting) de cultivares dos diferentes segmentos/grupos varietais dessa hortaliça.

Palavras chave: Resistência, marcadores, seleção assistida, melhoramento. 


\section{ABSTRACT}

Fusarium wilt, caused by different races of the fungus Fusarium oxysporum f. sp. lactucae (FOLAC), is one of the most economically important diseases of lettuce (Lactuca sativa L.), in many tropical and subtropical regions of the world. Marker-assisted selection (MAS) could be exploited as a tool in combination with classical breeding programs, in order to facilitate the development of lettuce varieties with resistance to FOLAC. Inheritance studies indicated a monogenic genetic control with high penetrance of FOLAC race 1 resistance in cultivar 'Vanda'. However, molecular markers linked to FOLAC race 1 resistance factor(s) derived from this cultivar are yet not available, precluding a precise determination of its chromomosomal localization. In this context, the objective of this study was to establish a collection of PCR primers in order to enable the identification of markers linked to the genetic factor(s) associated with FOLAC race 1 resistance. The present molecular marker platform consists of a collection of primers that were selected to anneal to nine genomic regions uniformly distributed along the nine lettuce chromosomes, according to the information available in the Compositae Genome Project Database. Most of the known disease resistance genes in lettuce are located in five major clusters (major resistance clusters - MRCs). In this work, a subset of 98 primers pairs scattered in five MRCs of the lettuce genome located on the chromosomes/linkage groups 1, 2, 4, $7 \& 8$ was initially exploited. Disease resistance analogs (DR-analogs), SCAR (Sequence Characterized Amplified Regions), CAPS (Cleaved Amplified Polymorphic Sequence), and microsatellite markers were screened for polymorphisms between the cultivars 'Gizele' (susceptible) and 'Vanda' (resistant). Polymorphic DR analog markers markers were obtained between the contrasting cultivars and they were checked for linkage to FOLAC race 1 using $F_{2}(n=82)$ and $\mathrm{F}_{3}$ mapping populations derived from a cross between 'Gizele' $x$ 'Vanda' after bioassays 
employing controlled fungal inoculation. However, no clear evidence of genetic linkage with the factors of resistance to FOLAC race 1 was obtained with the subgroups of primers examined, suggesting that these factors are not located in the MRCs of the chromosomes/linkage groups 1 , 2, 4, 7 \& 8. Nonetheless, this collection of molecular markers may serve as a database for breeding programs especially in studies dealing with the genetic variability of germplasm collections as well as in the search for markers linked to other traits of interest for lettuce breeding programs. The identification of several molecular markers in several resistance gene families in the lettuce genome is important and this information can be used in fingerpriting systems of cultivars from different varietal groups.

Keywords: resistance, molecular markers, marker assisted, breeding, crop improvement. 


\section{INTRODUÇÃO}

A seleção assistida por marcadores moleculares (Marker Assisted Selection - MAS) é uma poderosa ferramenta para uso em programas de melhoramento, especialmente para incorporação de fatores de resistência a doenças (Agrama et al., 2007; Zhao et al., 2011; Kwon et al., 2013). Nos sistemas de MAS, a incorporação de genes de resistência pode ser monitorada de maneira precisa e específica sem mesmo requerer a inoculação e/ou presença do patógeno, reduzindo o tempo e os custos associados com bioensaios de campo e telado. Outra vantagem dos sistemas de MAS é a possibilidade conduzir simultaneamente processos de seleção para múltiplos fatores de resistência contra uma ampla gama de agentes patogênicos, o que torna possível a rápida ‘piramidação' de genes de interesse em uma única cultivar ou linhagem elite (Peleman \& van der Voort, 2003; Simko et al., 2007; Collard \& Mackill, 2008).

O desenvolvimento de mapas genéticos densos (i.e. com um número elevado de marcadores) tem permitido a localização física dos genes nos cromossomos, a estimativa do número de loci envolvidos no controle de uma dada característica (qualitativa ou quantitativa) e a estimativa da magnitude do efeito destes loci no fenótipo de interesse (Collard \& Mackill, 2008). Para o gênero Lactuca, diversos mapas foram obtidos utilizando populações derivadas de cruzamentos intraespecíficos e/ou interespecíficos (Kesseli et al., 1994; Witsenboer et al., 1995; Waycott et al., 1999; Johnson et al., 2000; Jeuken et al., 2002; Syed et al., 2006). Para tal, diversos sistemas de marcadores bioquímicos e moleculares foram empregados na genética da alface incluindo, isoenzimas (Kesseli \& Michelmore 1986); Restriction fragment length polymorphism - RFLP (Kesseli et al., 1991); Randomly amplified polymorphic DNA - RAPD (Kesseli et al., 1994); Sequence characterized amplified regions - SCAR (Maisonneuve et al., 1994); Retrotransposon-based sequence specific amplification polymorphism (Syed et al., 2006); 
Amplified fragment length polymorphism - AFLP (Hill et al., 1996); Simple sequence repeats SSR (Van de Wiel et al., 1999; Rauscher \& Simko, 2013); Target region amplification polymorphism - TRAP (Hu et al. 2005); Expressed sequence tag-based SSR - EST-SSR (Simko, 2009); Single-stranded conformational polymorphism - SSCP (McHale et al., 2009); Single nucleotide polymorphism - SNP (Kwon et al., 2013) e Single position polymorphism - SPP (Stoffel et al., 2012).

Os modernos sistemas de marcadores moleculares utilizados em genética vegetal permitem a genotipagem com alto rendimento (Truong et al., 2012). Estes marcadores estão sendo utilizados na construção de vários mapas de ligação de alface (Truco et al. 2007, 2013), incluindo estudos envolvendo a localização cromossômica de genes de resistência a doenças (Paran \& Michelmore, 1993; Meyers et al., 1998; McHale et al., 2009) e no desenvolvimento de sistemas de MAS para essa hortaliça (Moreno-Vázquez et al., 2003; Simko et al., 2009).

Um mapa molecular de referência em alface foi construído utilizando linhagens RILs (Recombinant Inbred Lines) derivadas da população L. sativa 'Salinas' x L. serriola 'UC96US23' (Truco et al., 2007). Este mapa engloba com mais de 700 marcadores AFLP e SSR. Posteriormente, um mapa genético ultradenso foi gerado com 13.943 loci baseados em sequências transcritas de alface e outras espécies da família Compositae organizadas em um chip de microarray (Truco et al., 2013). Os loci foram catalogados e ordenados de acordo com a distância genética e organizados em cromossomos para facilitar a visualização com a ajuda do software "GBrowse" (http://www.Gbrowse.org). O Lettuce Genome Browser pode ser acessado após inscrição e login no site https://lgr.genomecenter.ucdavis.edu.

De acordo com as estimativas, a alface possui cerca de 45.000 genes. Desta forma, esse mapa representa um enorme avanço analítico, disponibilizando cerca de $1 / 3$ dos genes que 
codificam proteínas em alface (Truco et al., 2013). Mais recentemente, a metodologia de Genotyping-by-sequencing (GBS) foi aplicada na análise genômica de alface permitindo o desenvolvimento de mais de 1.000 marcadores SNPs em uma população de mapeamento derivada do cruzamento entre L. sativa 'Salinas 88' $x$ L. sativa 'La Brilhante' (Truong et al., 2012). Estes marcadores foram adicionados aos mapas de ligação de referência da alface (Truco et al., 2013).

Da mesma, forma foi construído um mapa de referência por McHale et al. (2009) e Christopoulou et al. (2015a,b), contendo um coleção de marcadores associados com 36 loci e 20 QTLs associados a fenótipos de resistência/tolerância a dez patógenos e um inseto (Tabela 3-1). Os seguintes patógenos e doenças já tiveram os fatores de resistência e QTLs mapeados em alface: raças fisiológicas de Bremia lactucae (míldio); corky root (Sphingomonas suberifanciens); lettuce dieback, causado pelo complexo viral (Tomato bushy stunt virus - TBSV, Lettuce necrotic stunt virus - LNSV); outras viroses (Lettuce mosaic virus - LMV e Turnip mosaic virus - TuMv); root downy mildew, causado por Plasmopara lactucae-radicis; oídio (Golovinomyces cichoracearum sensu stricto = Erysiphe cichoracearum) ; big-vein (Mirafiori lettuce big-vein virus - MLBVV); antracnose (Microdochium panattoniana); podridão de esclerotínia (Sclerotinia minor e S. sclerotiorum); mancha bacteriana (Xanthomonas campestris pv. vitians); murcha de verticílio (Verticillium dahliae) e a murcha de fusário (F. oxysporum f. sp. lactucae).

A maioria dos genes de resistência a doenças identificados no genoma da alface estão localizados em cinco grandes agrupamentos físicos ou clusters (Major Resistance Clusters MRCs). Dos cinco principais MRCs em alface, o MRC2 (cromossomo 2) é o mais extensamente estudado. O MRC2 é composto por nove genes Dm (downy mildew resistance genes - Dm1, 
Dm2, Dm3, Dm6, Dm14, Dm15, Dm16, Dm18 e Dm50). Este cluster inclui Dm3 (que foi o primeiro gene de resistência clonado em alface) (Shen et al., 2002; Christopoulou et al., 2015a,b), QTLs para resistência parcial contra raças de míldio (qDMR2.2 e qDM2.1) (Simko et al., 2015), o gene de resistência ao pulgão de raiz $(R a)$ (Ellis et al., 2002), resistência a Tomato bushy stunt virus (Tvrl) (Grube et al., 2005), um QTL associado com resistência a antracnose (qANT) (McHale et al., 2009), genes de resistência a mancha bacteriana (Xarl e Xcvr) (Hayes $\boldsymbol{e t}$ al., 2014; Wang et al., 2016), QTLs de resistência ao oídio (pm-2.1 e pm-2.2) (Simko et al., 2014) e um número variável de 15 a 42 membros da família de genes candidatos de resistência 2 (RGC2) do tipo CNL (Shen et al., 2002; Kuang et al., 2004), bem como de alguns NBS-LRR fora da família RGC2 (McHale et al., 2009). A análise de sequências de genes RGC2 de 47 acessos de L. sativa indica uma complexidade genética desse locus que inclui mutações, conversão gênica e recombinação resultando em numerosas variantes dos membros desta família (Kuang et al., 2004). A partir do draft do genoma da alface (L. sativa cv. 'Salinas') foi possível identificar 754 genes nesse cluster, dos quais 61 são NBS-LRR, dois são RLKs e cinco são RLPs (Christopoulou et al., 2015a, b).

O cluster MRC1 (cromossomo 1) é constituído por oito genes Dm (Dm5/8, Dm10, Dm17, Dm25, Dm36, Dm37, Dm43 e Dm45) (Hulbert \& Michelmore, 1985; Landry et al., 1987; Parra et al., 2016), por um QTL (qDMR1.1) associado com a resistência parcial ao míldio (downy mildew) (Jeuken \& Lindhout, 2002), pelo gene de resistência a isolados de Lettuce mosaic virus (Mo2) (McHale et al., 2009), resistência a Turnip mosaic virus (Tu) (Robbins et al., 1994), resistência recessiva a Plasmopara lactucae-radicis (plr) (Witsenboer et al., 1995), por QTL de resistência ao oídio (pm-1.1) (Simko et al., 2014), por fatores genéticos controlando uma reação de hipersensibilidade em resposta as proteínas efetoras AvrB, AvRpt2 e AvrRpml de 
Pseudomonas syringae (AvrB-HR, AvrRpt2-HR e AvrRpm1-HR) (Wroblewski et al., 2009) e pelos QTLs qFUS1.1 e qFUS1.2 associados com resistência parcial a murcha de fusário (Truco et al., comunicação pessoal). A partir de estudos de mapeamento com marcadores EST de sequências expressas (Expressed sequence tag), McHale et al. (2009) identificaram membros da família RGC16 (TNL) e membros da família RCC1 (CNL) dentro da região do cluster MRC1.

A disponibilidade de uma primeira versão (draft) do genoma da alface (L. sativa cv. ‘Salinas') também permitiu a caracterização detalhada da arquitetura genômica do locus MRC1. Conjuntos de dados de 39.000 modelos de genes para a presença de características de domínios Pfam (Lettuce Genome Resouce) identificaram 365 modelos de genes com o NB-ARC (com e sem a presença de CC, TIR e domínios LRR) e 687 genes que codificam LRR (com ou sem presença do domínio kinase) (Christopoulou et al., 2015a,b).

O cluster MRC4 (cromossomo 4) se extende por cerca de $25 \mathrm{cM}$ e é composto por sete loci controlando resistência à míldio $(D m 4, D m 7, D m 11, D m 24, D m 38, D m 44$ e $D m 48)($ Hulbert \& Michelmore 1985; Landry et al., 1987; Parra et al., 2016), por QTLs associados com resistência a murcha de fusário (qFUS4.1) (Truco et al., comunicação pessoal), resistência a big-vein (BV2 e BV3) (Hayes et al., 2010) e o gene recessivo mo-1 que controla resistência a patotipos do potyvirus Lettuce mosaic virus (Nicaise et al., 2003). Membros da família RGC12 (TNL) são predominantes nesse cluster. Existem 21 genes do tipo NBS-LRR, sendo 18 TNL atribuídos a família de genes RGC12, com base em suas sequências e três CNL (Christopoulou et al., 2015b).

No cromossomo 7 se localizam dois QTLs de resistência para míldio ( $q D M 7.1$ e qDMR7.1) (Christopoulou et al., 2015a,b), um QTL para resistência a oídio (pm7-1) (Simko et al., 2014) e um fator de resistência a murcha de fusário (FUS3) (Michelmore et al., 2010). 
Por sua vez, três MRcs (MRC8A, MRC8B e MRC8C) estão localizados no cromossomo 8 que co-segregam com diferentes fatores genéticos relacionados com resistência a doenças. O MRC8A é composto por 1132 genes, dos quais 23 genes são potencialmente envolvidos no reconhecimento do patógeno: quatro TNL (RGC4), dois CNLs (RCC27), oito RLKs, quatro RLPs, um TIR e quatro genes que codificam LRR. O MRC8B co-segrega com HR para AvrRps4, contém 127 genes, dos quais 36 são membros do RGC4. Já o MRC8C é o mais complexo, contém 348 genes, 26 são do tipo NBS-LRR, 9 membros de RGC15, 11 de RGC9, 4 de RGC29, 1 de RGC7 e 1 de RGC43. Neste cluster há presença de um QTL de resistência a murcha de fusário ( $q F U S 8.1$ ) e um QTL para $V$. dahliae ( $q V R T$ ) (Christopoulou et al., 2015a,b; Truco et al., comunicação pessoal).

Em relação à resistência a FOLAC raça 1, estudos indicaram um controle genético relativamente simples na cultivar 'Vanda' (ver capítulo 2), com os resultados de segregação indicando um controle monogênico dominante com penetrância elevada, porém incompleta (Cabral et al., 2015; ver capítulo 2). No entanto, marcadores moleculares ligados a fatores de resistência ao FOLAC raça 1 derivados dessa cultivar ainda não estão disponíveis impedindo a determinação de sua localização cromossômica. Neste contexto, o objetivo do presente trabalho foi estabelecer uma coleção de primers visando identificar marcadores ligados e/ou genes candidatos associados com a resistência a FOLAC raça 1. Inicialmente foram selecionados e sintetizados 90 oligonucleotídeos, usando informações disponíveis no Compositae Genome Project Database. Esses marcadores estão distribuídos nos nove cromossomos da alface (dez regiões/primers por cromossomo), incluindo marcadores dispersos em cinco dos principais MRCs do genoma da alface localizados nos cromossomos/grupos de ligação (1, 2, 3, 4 \& 8), descritos acima. Marcadores moleculares do tipo Disease resistance analogs (DR-analogs), 
CAPS (Cleaved Amplified Polymorphic Sequence), SCAR (Sequence Characterized Amplified Regions) e microssatélites foram sintetizados e validados em uma população $\mathrm{F}_{2}$ segregando para reação a FOLAC raça 1. No presente trabalho, essa plataforma foi aplicada visando identificar marcadores moleculares ligados a fatores de resistência a raça 1 de FOLAC.

\section{OBJETIVOS}

\subsection{Objetivo Geral}

- Caracterizar marcadores derivados de genes análogos de resistência (RGAs) presentes em cinco grandes agrupamentos físicos ou clusters (major resistance clusters MRCs) no genoma da alface em populações segregantes obtidas a partir de cruzamentos entre um parental suscetível e um resistente a raça 1 de Fusarium oxyporum f. sp. lactucae, visando identificar marcadores moleculares potencialmente associados o(s) fator(es) de resistência a esse patógeno.

\subsection{Objetivos Específicos}

- Amplificar de forma específica, RGAs em materiais contrastantes para resistência a raça 1 de $F$. oxyporum f. sp. lactucae, utilizando primers descritos no site https://lgr.genomecenter.ucdavis.edu).

- Desenhar e validar marcadores moleculares baseados na análise de sequências dos RGAs, potencialmente ligados aos fatores de resistência a FOLAC raça 1.

- Ampliar as ferramentas moleculares disponíveis para mapear outros genes de resistência associados com os mecanismos genéticos que regulam a diferentes interações planta-patógeno em alface. 


\section{MATERIAL \& MÉTODOS}

\subsection{Cruzamentos entre parentais contrastantes para resposta a FOLAC raça 1 e}

desenvolvimento de populações segregantes - Foram realizados cruzamentos entre o parental suscetível (PS) 'Gizele’ (cultivar comercializada no Brasil pela a Empresa Topseed) e o parental resistente (PR) 'Vanda' (Empresa Sakata Seed Sudamerica) que foi usado exclusivamente como progenitor masculino (= doador de pólen). As duas cultivares utilizadas como parentais são do segmento varietal do tipo 'Crespa'. As sementes resultantes dos cruzamentos (geração $F_{1}$ ) foram semeadas em bandejas e as plantas individuais produzidas foram autofecundadas, para constituir a geração $F_{2}$. Progênies $F_{3}$ foram obtidas a partir da autofecundação de plantas individuais da geração $\mathrm{F}_{2}$. Os parentais contrastantes e as populações $\mathrm{F}_{1}, \mathrm{~F}_{2}$ e $\mathrm{F}_{3}$ foram utilizadas nesse estudo.

\subsection{Caracterização fenotípica das linhagens parentais e populações segregantes -} Inicialmente 30 plantas de cada um dos parentais contratantes, 30 plantas da geração $\mathrm{F}_{1}, 82$ plantas $F_{2}$ e 719 plantas da geração $F_{3}$ foram inoculadas com o isolado CMM-3577 (Fus-209) (Cabral \& Reis, 2013) da raça 1 de FOLAC (ver capítulo 2). Para confirmar os genótipos dos indivíduos da $\mathrm{F}_{2}$, entre 9 e 16 plantas (de cada progênie $\mathrm{F}_{3}$ ) foram avaliadas para a resposta ao fungo. $\mathrm{O}$ isolado do fungo foi cultivado por cinco dias em meio de cultura BDA-t (BDA suplementado com $50 \mathrm{ppm}$ de tetraciclina). A suspensão de esporos foi ajustada para uma concentração de $3 \times 10^{6}$ microconídios $/ \mathrm{mL}$. Para produção das mudas, as sementes foram semeadas em bandejas de isopor, preenchidas com substrato esterilizado (Plantmax ${ }^{\circledR}$ ). Mudas com 25-30 dias após o semeio foram removidas das células e as raízes lavadas em água corrente para eliminar o resíduo de substrato ainda aderido às raízes. A porção apical das raízes foi cortada (aproximadamente $2 \mathrm{~cm}$ ), com auxílio de tesoura esterelizada, e mergulhadas em $50 \mathrm{~mL}$ da suspensão de esporos, por três minutos. Em seguida as mudas foram transplantadas para vasos de 
2 L contendo uma mistura de argila, esterco bovino, areia e palha de arroz carbonizada esterilizada. Estes vasos foram irrigados anteriormente (uma hora antes do plantio). Depois disto, $3 \mathrm{~mL}$ da suspensão foi adicionado no colo de cada plântula. As plantas não foram irrigadas novamente no dia da inoculação para evitar a perda do inóculo através do escoamento superficial. Posteriormente foram mantidas em casa de vegetação com temperaturas variando de 25 a $35^{\circ} \mathrm{C}$ e fotoperíodo de 12 horas. Os fenótipos das plantas inoculadas foram avaliados aos 20 dias após a inoculação de acordo com a escala de notas adaptada de Santos (1996), sendo 1 = plantas sem sintomas; $\mathbf{2}=$ plantas sem sintomas de murcha ou amarelecimento, mas com escurecimento vascular; $\mathbf{3}=$ plantas com escurecimento vascular intenso e com início de murcha ou amarelecimento foliar; $\mathbf{4}=$ plantas com murcha intensa, associada com amarelecimento e necrose foliar; $\mathbf{5}=$ plantas mortas. Com base nas notas recebidas as plantas foram classificadas como resistentes $(\mathrm{R} \leq 2)$ ou suscetíveis $(\mathrm{S}>2)$.

\subsection{Extração de DNA de genômico de linhagens parentais e indivíduos das populações}

segregantes - As amostras foliares foram coletadas dez dias após a inoculação e mantidas em casa de vegetação. O DNA foi extraído individualmente de cada planta das linhagens parentais e de indivíduos das populações segregantes, de acordo com a metodologia de CTAB $2 \mathrm{X}$ com a incorporação de algumas modificações (Boiteux $\boldsymbol{e t}$ al., 1999). As amostras das folhas foram trituradas no cadinho de porcelana na presença de nitrogênio líquido. Em seguida, colocadas em tubos com $750 \mu \mathrm{L}$ de $\mathrm{CTAB} 2 \mathrm{X}$, as amostras foram retiradas e colocadas em banho-maria a $65^{\circ} \mathrm{C}$ durante 10 minutos, acrescenta-se, após esse tempo, $750 \mu \mathrm{L}$ de clorofil em cada tubo e agita-se no vortex por aproximadamente 30 segundos. As amostras foram então centrifugadas por 9.000 rpm durante 5 minutos. Os tubos foram retirados da centrifuga $600 \mu \mathrm{L}$ do sobrenadante foram retirados e colocados em novos tubos de micro-centrífuga. Foram acrescentados $300 \mu \mathrm{L}$ de isopropanol gelado e para homogeneizar, os tubos foram suavemente agitados de forma manual e 
posteriormente centrifugados a $12.000 \mathrm{rpm}$ durante 13 minutos. O sobrenadante foi eliminado e o pellet lavado com álcool $70 \%$. Os tubos foram colocados na estufa a $37^{\circ} \mathrm{C}$ por 20 minutos, depois se acrescenta $50 \mu \mathrm{L}$ de TE+RNAse e coloca-se os tubos na geladeira. No outro dia, as amostras foram agitadas no vortex e os DNAs então extraídos foram guardados no freezer. As quantificações de DNA foram feitas com o espectrofotômetro (NanoDrop ${ }^{\circledR}$ ). Para confirmação da qualidade das amostras de DNA, alíquotas foram utilizadas em uma reação de PCR em condições previamente testadas. $\mathrm{O}$ resultado negativo da amplificação indicou a presença de potenciais inibidores da reação de PCR na maioria das amostras. Desta forma a os DNAs foram repurificados usando o kit Power Clean ${ }^{\circledR}$ Pro DNA Clean-up, seguindo os padrões recomendados pelo fabricante do kit (MO BIO Laboratories - Carlsbad, California, USA). Após este procedimento a reação de PCR foi repetida, desta vez com sucesso, indicando que os inibidores de PCR foram removidos.

\subsection{Plataforma de marcadores do tipo Disease Resistance Analogs (DR analogs) em}

alface - A presente plataforma consiste de uma coleção de oligonucleotídeos (primers) que foram selecionados para anelar em regiões uniformemente distribuídas nos nove cromossomos da alface, de acordo com as informações disponiveis no Compositae Genome Project Database. Um subgrupo de 98 pares de primers foi empregado no presente capítulo (Tabela 3-2). Estes primers foram derivados de sequências do tipo Resistance Gene Analogs (RGAs) dispersas em cinco dos principais MRCs (Major Resistance Clusters) do genoma da alface localizados nos cromossomos (Cr.)/grupos de ligação 1, 2, 3, 4 \& 8. De acordo com dados reportados na literatura, essas cinco regiões MRCs são mais ricas em fatores de resistência a doenças, incluindo fatores reportados controlando resistência para isolados de FOLAC (Christopoulou et al., 2015a,b). Estes 98 pares de primers foram obtidos no site http://cgpdb.ucdavis.edu/GeneticMapViewer/display/ ou foram sintetizados a partir de sequências disponíveis no mesmo site. Nesta coleção, foram selecionados 
apenas pares de primers que anelavam com sequências relacionadas com 'motivos' (= regiões conservadas) com assinaturas do tipo NBS (Nucleotide Binding Sites $=$ sítios de ligação de nucleotídeos), LRR (Leucine rich repeats = regiões ricas em códons correpondentes ao aminoácido leucina) e RLK (Receptor-like kinase = Receptores do tipo quinases) (McHale et al., 2009). Essas famílias gênicas estão presentes em diferentes genomas de membros da Asteraceae (Compositae) e em outras famílias botânicas. Marcadores do tipo SRRs e SCAR previamente descritos por Simko et al. (2009) e Aruga et al. (2012) foram também incorporados na plataforma e nas análises.

\subsection{Reação de PCR com primers anelando em regiões dos cromossomos $1,2,4,7 \& 8$}

contendo DR analogs - Os primers foram inicialmente avaliados nos dois parentais e em 12 indivíduos da população $\mathrm{F}_{2}$ contrastantes para resposta a FOLAC raça 1 (seis plantas resistentes e seis suscetíveis), baseado na severidade da doença. Amplicons presentes na maior parte dos indivíduos resistentes e ausentes nos suscetíveis foram selecionados. Amplicons em repulsão (i.e. associados com o fenótipo suscetível) também foram selecionados. Em uma segunda etapa, os primers capazes de manter o polimorfismo nos 12 indivíduos contrastantes foram validados em 82 indivíduos da população $\mathrm{F}_{2}$. Amplicons estáveis nos 12 indivíduos contrastantes foram purificados e sequenciados. A análise da sequência destes amplicons permitiu o desenho de novos primers a serem utilizados como potenciais marcadores do tipo CAPS (Tabela 3-2, Figuras 3-2, 3-3 \& 3-4). O objetivo desta etapa foi aumentar probabilidade de identificar polimorfismos ligados a resposta de resistência a FOLAC raça 1. As reações de amplificação foram realizadas utilizando $2 \mu \mathrm{L}$ de DNA genômico $(50 \mathrm{ng} / \mu \mathrm{L})$, em volume final de 12,5 $\mu \mathrm{L}$, contendo 1,25 $\mu \mathrm{L}$ de tampão $10 \mathrm{X}\left(100 \mathrm{mM}\right.$ Tris-HCl, $500 \mathrm{mM} \mathrm{KCl,} \mathrm{pH} \mathrm{8.3),} \mathrm{0,6} \mu \mathrm{L}$ de $\mathrm{MgCl}_{2}$ (50 mM), 0,5 $\mu \mathrm{L}$ de dNTPs $(2,5 \mathrm{mM}$ cada), 0,2 $\mu \mathrm{L}$ de Taq DNA polimerase $(5 \mathrm{u} / \mu \mathrm{L}), 0,3 \mu \mathrm{L}$ de cada primer, 7,35 $\mu \mathrm{L}$ de $\mathrm{H}_{2} \mathrm{O}$ Milli-Q. O programa utilizado para amplificação dos fragmentos foi 
de um ciclo inicial de $94^{\circ} \mathrm{C}$ por 4 min, seguido de: 35 ciclos de $94^{\circ} \mathrm{C}$ por 1 min para a desnaturação, 1 min para anelamento (temperatura variável), e $72^{\circ} \mathrm{C}$ por 2 min para extensão, o ciclo final constituiu-se $72^{\circ} \mathrm{C}$ por $7 \mathrm{~min}$ e $4^{\circ} \mathrm{C} \infty$. As condições de PCR foram otimizadas em termos de temperatura de anelamento para cada primer utilizado (Tabela 3-2).

3.6. Reações de sequenciamento dos amplicons - Os amplicons obtidos foram diretamente sequenciados utilizando o protocolo BigDye ${ }^{\circledR}$ Terminator Cycle Sequencing Ready Reaction Kit version 3.1 (Applied Biosystems). O sequenciamento foi realizado em um sequenciador ABI PRIM 3100 da Embrapa Hortaliças (CNPH).

3.7. Análise das sequências - Sequências consenso foram obtidas usando o programa SeqMan (DNAStar) e as sequências nucleotídicas foram analisadas usando EditSeq (DNAStar). A qualidade das sequências foi avaliada através do programa SeqMan (Lasergene, Madison,WI) e a sequências de baixa qualidade foram removidas (Allex, 1999). As sequências foram comparadas com as disponíveis no banco de dados do GenBank e analisadas para níveis de identidade usando o algoritmo BLASTn, disponível online (Altschul et al., 1990). O alinhamento das sequências e o cálculo das identidades nucleotídicas foram realizados por meio do software Megalign (Lasergene, Madison, WI), utilizando-se o método Clustal W.

3.8. Marcadores CAPS - A partir da informação de sequências, sítios de clivagem de enzimas de restrição foram identificados usando o programa SeqMan (DNAStar), visando desenvolver marcadores do tipo CAPS. O corte com enzimas de restrição de cada amostra após PCR com os primers originais seguiram o protocolo do fabricante. Foram adicionados $5 \mu \mathrm{L}$ de azul de bromofenol e as amostras foram aplicadas em gel de agarose 1,5\%, já suplementado com brometo de etídeo. Os fragmentos de DNA amplificados foram separados por eletroforese em tampão TBE (Tris-Borato 45 mM e 1 mM EDTA), a 120V, por um período de aproximadamente 2 horas. Os géis foram fotografados sob luz ultravioleta, tendo-se utilizado o marcador $1 \mathrm{~Kb}$ Plus 
DNA Ladder ${ }^{\circledR}$ (Invitrogen) para análise dos produtos obtidos.

\section{RESULTADOS}

\subsection{Genotipagem das linhagens parentais e da população $F_{2}$ para marcadores $D R$ -} analogs potencialmente ligados a resistência a raça 1 de FOLAC-Dos 98 pares primers utilizados, 42 não amplificaram e/ou foram inespecíficos (i.e. apresentaram mais de uma banda) usando o DNA genômico dos dois parentais contrastantes como molde. Cinquenta e três primers produziram amplicons monomórficos e que foram caracterizados via sequenciamento. Três amplicons apresentaram polimorfismos entre os parentais do tipo INDEL (inserção/deleção). Os três primers que geraram amplicons polimórficos com INDELs foram LE0395 (localizado no cromossomo 8), LM0035 (localizado no cromossomo 8) e LE3164 (localizado no cromossomo 7). A estabilidade desses polimorfismos foi avaliada tomando-se amostras de seis indivíduos $\mathrm{F}_{2}$ resistentes e seis indivíduos $\mathrm{F}_{2}$ suscetíveis a FOLAC raça 1. O primer LM0035 gerou um amplicon de aproximadamente 1500 pb associada com indivíduos resistentes, enquanto os indivíduos suscetíveis apresentaram um amplicon de aproximadamente 1000 pb. O primer LE0351 amplificou uma banda de aproximadamente $550 \mathrm{pb}$ em indivíduos resistentes e uma de 500 pb em indivíduos suscetíveis. O primer LE0395 gerou um amplicom de aproximadamente 550 pb para indivíduos resistentes e 650 pb para indivíduos suscetíveis. Em seguida, houve a validação desses primers em 82 indivíduos segregantes da população $\mathrm{F}_{2}$, observando-se a não cosegregação desses marcadores com o fenótipo de resistência, ou seja, há eventos de recombinação entre o fator de resistência e os marcadores avaliados. (Tabela 3-4).

4.2. Análises Blast dos amplicons clonados e seqüienciados - Os resultados das análises de sequências dos 53 amplicons monomórficos obtidos com os primers da Tabela 3-2 estão apresentados na Tabela 3-3. Como esperado, diversos dos amplicons seqüenciados 
corresponderam a sequências com identidade com genes de resistência a doenças descritos em alface e outras espécies vegetais (Tabela 3-3). Alguns amplicons sequenciados apresentaram níveis de identidade elevados com genes da família Flowering locus $T$ (FT) que estão relacionados com a indução floral e outros processos de desenvolvimento (Fukuda et al., 2011;

\section{Pin \&Nilsson, 2012).}

4.3. Marcadores do tipo CAPS - Apenas três (3) dos (53) amplicons sequenciados apresentaram polimorfismos do tipo SNPs. Estes três amplicons (representativos de DR analogs) foram utilizados para o desenho de marcadores do tipo CAPS (Figuras 3-2, 3-3 \& 3-4). O padrão de amplicons após PCR com o par de primers LE0351-F/ LE0351-R (localizado no cromossomo 4), LE0337-F/ LE0337-R (localizado no cromossomo 4) e M4241-F/ M4241-R (localizado no cromossomo 7) foram de uma única banda aproximadamente 339 pb, 592 pb e 197 pb, respectivamente. No entanto, após a clivagem com as enzimas de restrição MspAII, BstNI e Msel, as plantas apresentaram três distintos padrões de bandas. No caso do par de primers 'LE0351-F/ LE0351-R', uma banda intacta (não clivada) de 339 pb associada com indivíduos homozigotos resistentes, duas bandas ( $251 \mathrm{pb}$ e $88 \mathrm{pb}$ ), resultando da clivagem completa pela MspAII de todos os produtos de de PCR para indivíduos homozigotos suscetíveis e três bandas (339 pb, 251pb e $88 \mathrm{pb})$ para indivíduos heterozigotos, que possuem as duas variantes alélicas do marcador (Figura 3-1). Nesse ensaio de genotipagem, do total de 68 plantas da população $F_{2}$ foram observadas as seguintes frequências de classes genotípicas: 42 genótipos associados com plantas heterozigotas, 14 plantas apresentaram genótipo associado com plantas homozigotas suscetíveis e 12 genótipos associados com plantas homozigotas resistentes. Para o par de primers 'LE0337-F/ LE0337-R', uma banda intacta (não clivada) de 592 pb associada com indivíduos homozigotos suscetíveis, duas bandas (437 pb e 155pb), resultando da clivagem completa pela Bst NI de todos 
os produtos de PCR para indivíduos homozigotos resistentes e três amplicons (437 pb, 437 pb e $155 \mathrm{pb}$ ) para indivíduos heterozigotos, possuindo duas variantes do marcador (Figura 3-1). Nesse ensaio de genotipagem do total de 59 plantas da população $F_{2}$ foram observadas as seguintes frequências de classes genotípicas: 43 plantas apresentaram genótipo associado com plantas heterozigotas, 14 genótipos associados com plantas homozigotas suscetíveis e dois genótipos associados com plantas homozigotas resistentes. Os padrões de bandas dos primers 'M4241-F/ M4241-R' foram os seguintes: uma banda intacta (não clivada) de 197 pb associada com indivíduos homozigotos resistentes, duas bandas (106 pb e 91 pb), resultando da clivagem completa pela Msel de todos os produtos de PCR para indivíduos homozigotos suscetíveis e três bandas (197 pb, 106 pb e 91 pb) para indivíduos heterozigotos, que possuem as duas variantes alélicas do marcador (Figura 3-1). Nesse ensaio de genotipagem do total de 76 plantas da população $\mathrm{F}_{2}$ foram observadas as seguintes frequências de classes genotípicas: 48 plantas apresentaram genótipo associado com plantas heterozigotas, 19 genótipos associados com plantas homozigotas suscetíveis e 09 genótipos associados com plantas homozigotas resistentes. Os marcadores moleculares que foram testados na população segregante apresentaram valores variando entre 24 a 64\% de recombinantes (Tabela 3-4). Desta forma, marcadores polimórficos entre os parentais contrastantes foram obtidos, mas, dentro do subgrupo analisado de marcadores, não foram obtidas evidências inequívocas de ligação genética com os fatores de resistência a FOLAC raça 1, sugerindo que este(s) fator(es) não se localizam nos MRCs dos cromossomos/grupos de ligação $1,2,4,7$ \& 8.

\section{DISCUSSÃO}

A maioria dos amplicons e marcadores moleculares obtidos/caracterizados nesse trabalho apresentaram níveis de identidade com proteínas contendo os 'motivos' das famílias gênicas 
NBS-LRR e RLK localizadas em cinco dos principais clusters MRCs (Major Resistance Clusters) dispersos nos cromossomos/grupos de ligação 1, 2, 3, 4 \& 8, que co-segregam com vários fenótipos de resistência a doenças em alface (McHale et al., 2009; Michelmore et al., 2010). Os clusters de genes são resultado de duplicação em tandem de sequências parálogas e são relativamente comuns em genomas de plantas, incluindo a alface (Meyers et al., 2003). Dentro desses clusters numerosos genes de resistência estão presentes controlando reações de defesa contra diversos patógenos, diferentes raças e patotipos (Van de Vossen et al., 2000). A formação de clusters de genes de resistência também pode facilitar a geração de diversidade genética e a evolução de novos genes de resistência com novas especificidades. Desta forma, a efetividade destes primers na amplificação de DR analogs em alface crespa (56 de 98 primers empregados) indica níveis elevados de conservação e que os mesmos poderão ser utilizados em projetos similares relacionados a outras doenças de alface ou mesmo na busca por marcadores associados com outras raças de FOLAC.

O desenho de marcadores moleculares do tipo DR analogs, SCAR, CAPS e SSR no grupo varietal crespa representa uma importante ferramenta para a identificação de potenciais loci de resistência para diferentes doenças da alface, embora no caso específico dos primers avaliados até o momento (que anelam com regiões dos cromossomos/grupos de ligação 1, 2, 4, 7 \& 8) indicam que o(s) fator(es) de resistência a FOLAC raça 1 não estejam em estreita ligação gênica com essas regiões genômicas da alface.

Os 53 amplicons de que foram sequenciados e analisados são, como esperado, majoritariamente do tipo DR analogs, apresentando motivos de genes de resistência (Tabela 3-3). Este resultado comprova a utilidade destes primers para amplificação deste grupo de sequências no genoma de cultivares de alface do segmento crespa. O número de polimorfismos do tipo 
INDELs (3/98) e SNPs (3/53) se encontra dentro do esperado para esta classe de marcadores. A estratégia de uso de marcadores moleculares do tipo CAPS foi bastante eficiente na genotipagem dos SNPs presentes em bandas monomórficas e sem INDELs.

Da mesma forma, a identificação de vários marcadores dentro das diferentes famílias de genes de resistência é importante, já que podem ser utilizados em outros trabalhos de caracterização agronômica e bioquímica de alface. Alguns dos genes amplificados, como, por exemplo, as enzimas lipoxygenases estão envolvidas na resposta a estresses bióticos e abióticos, germinação e nas vias bioquímicas do ácido jasmônico e em processos de deteriorização de semente (Suzuki et al., 1996; Umate, 2011). Proteínas do tipo ciclase (CAPS), amplificadas neste estudo, são proteínas ligadas a actina e altamente conservadas, estando presentes em uma ampla gama de organismos, incluindo levedura, mosca, plantas e mamíferos. As proteínas CAPS estão envolvidas nas vias de sinalização específicas para cada espécie. Os genes Flowering locus $T$ (FT), também foram amplificados neste estudo, estando relacionados com o processo de indução floral. Além da floração, genes FT participam em vários processos de desenvolvimento, incluindo frutificação, crescimento vegetativo, controle estomático e tuberização. Essas funções multifacetadas das proteínas FT se devem a extensos eventos de duplicação de genes, que ocorrem de forma independente em quase todas angiospermas (Fukuda et al., 2011; Pin \&Nilsson, 2012) (Tabela 3-3).

Desta forma, marcadores polimórficos entre os parentais contrastantes foram obtidos, mas, dentro do subgrupo inicialmente analisado, não foram obtidas evidências inequívocas de ligação genética com os fatores de resistência a FOLAC raça 1, sugerindo que este(s) fator(es) não se localizam nos MRCs dos cromossomos/grupos de ligação 1, 2, 4, 7 \& 8. A próxima etapa do trabalho vai envolver a avaliação de um número maior de primers, incluindo aqueles gerados 
para a região do cromossomo 9 , que se mostrou potencialmente ligada ao gene de resistência a FOLAC raça 1 usando a estratégia de GBS (ver capítulo 4).

No presente trabalho, uma plataforma de marcadores moleculares, predominantemente do tipo DR Analogs, foi aplicada visando identificar regiões genômicas ligadas ao(s) fator(es) de resistência a raça 1 de FOLAC. No entanto, a utilidade dessa plataforma não se limita ao tema dessa investigação. De fato, o principal objetivo desta ação de pesquisa foi obter/gerar um conjunto de potenciais marcadores moleculares para permanente uso em projetos de mapeamento de fatores de resistência nessa cultura. Desta forma, espera-se validar marcadores moleculares que poderão ser utilizados na seleção assistida dentro de programas de melhoramento de alface crespa. 
Tabela 3-1. Código dos genes e QTLs associados com resistência/tolerância a doenças e pragas mapeados no genoma da alface (Lactuca sativa L.). Informações extraídas de Christopoulou $\boldsymbol{e t}$ al. (2015b).

\begin{tabular}{ll}
\hline Código & Patógeno/doença controlado pelo fator de resistência \\
\hline$D m$ & Resistência monogênica dominante ao míldio (Bremia lactuca) \\
$T v r$ & Resistência ao Tomato bushy stunt virus (TBSV) \\
$p l r$ & Resistência a Plasmopara lactucae-radicis \\
$M o$ & Resistência ao Lettuce mosaic virus (LMV) \\
$T u$ & Resistência ao Turnip mosaic virus (TuMV) \\
$c o r$ & Resistência ao Sphingomonas suberifaciens \\
$q F U S$ & QTL para resistência ao Fusarium oxysporum f. sp. lactucae \\
$q D M R$ & QTL para resistência ao míldio (Bremia lactuca) \\
$q D M$ & QTL para resistência de campo ao míldio (Bremia lactuca) \\
$q V R T$ & QTL para resistência ao fungo Verticillium dahliae \\
$V r 1$ & Resistência monogênica ao Verticillium dahliae \\
$q A N T$ & QTL para resistência a antracnose \\
$R a$ & Resistência ao afídeo radicular Pemphigus bursarius \\
AvrB-HR & HR contra o efector bacteriano AvrB \\
AvrRpt2-HR & HR contra o efector bacteriano AvRpt2 \\
AvrRpm1-HR & HR contra o efector bacteriano AvrRpm1 \\
AvrPpiC-HR & HR contra o efector bacteriano AvrPpiC \\
AvrRps4 & HR contra o efector bacteriano AvrRps4 \\
AvrPto-HR & HR contra o efector bacteriano AvrPto \\
Xarl & Resistência a mancha foliar bacteriana \\
\hline &
\end{tabular}


Tabela 3-1. Lista do subgrupo de 98 pares primers empregados, visando identificar marcadores associados com a resistência a Fusarium oxyporum f. sp. lactucae (FOLAC) raça 1 em alface. Esses marcadores foram derivados de sequências do tipo Resistance gene analogs (RGA) dispersas em dos cinco principais MRCs (major resistance clusters) do genoma da alface localizados nos cromossomos (Cr.)/grupos de ligação $1,2,4,7$ \& 8. Os pares de primers foram obtidos no site http://cgpdb.ucdavis.edu/GeneticMapViewer/display/ ou foram sintetizados a partir de sequências disponíveis no mesmo site. Marcadores do tipo SRR e SCAR previamente descritos por Simko et al. (2009) e Aruga et al. (2012) foram também incorporados nas análises.

\begin{tabular}{|c|c|c|c|c|}
\hline $\begin{array}{c}\text { Código do par de } \\
\text { primers }\end{array}$ & Sequencia do primer $(5-3)$ & Cr. & Fonte da informação da sequencia & Tipo \\
\hline LE0261-F & CCCAAGCTCAAGTTTCCTGA & 1 & http://cgpdb.ucdavis.edu/GeneticMap & RGA \\
\hline LE0261-R & TTACATGCGGTGGTTGGATA & 1 & http://cgpdb.ucdavis.edu/GeneticMap & RGA \\
\hline LE0243-F & TTGTGGGCATATCAACTCCA & 1 & http://cgpdb.ucdavis.edu/GeneticMap & RGA \\
\hline LE0243-R & GCCTTGAGGCTAGGACTGTG & 1 & http://cgpdb.ucdavis.edu/GeneticMap & RGA \\
\hline LE0172-F & AACCAATATAATGGGTTGCTTAAT & 1 & http://cgpdb.ucdavis.edu/GeneticMap & RGA \\
\hline LE0172-R & CCTTTTTACAGGCTGCTGCT & 1 & http://cgpdb.ucdavis.edu/GeneticMap & RGA \\
\hline LE0229-F & TGACTTGATGAAGCTGGCAC & 1 & http://cgpdb.ucdavis.edu/GeneticMap & RGA \\
\hline LE0229-R & GATTGTCGAGCCACAGTTGA & 1 & http://cgpdb.ucdavis.edu/GeneticMap & RGA \\
\hline LE0187-F & AAGCCTCTTCAAGGTGGACA & 1 & http://cgpdb.ucdavis.edu/GeneticMap & RGA \\
\hline LE0187-R & AAAAAGAAGAGACAAAGAGGCATA & 1 & http://cgpdb.ucdavis.edu/GeneticMap & RGA \\
\hline LE0427-F & CCTGATTTGGAGAGCGTGAT & 1 & http://cgpdb.ucdavis.edu/GeneticMap & RGA \\
\hline LE0427-R & CTGCAGTGAAACCACCAATG & 1 & http://cgpdb.ucdavis.edu/GeneticMap & RGA \\
\hline LE0193-F & TTCAGGCAACTCCATCACTG & 1 & http://cgpdb.ucdavis.edu/GeneticMap & RGA \\
\hline LE0193-R & GGAAGTGTTCCGCTCATGTT & 1 & http://cgpdb.ucdavis.edu/GeneticMap & RGA \\
\hline LK0005-F & TGAATTCGATACATGCAGCTTT & 1 & http://cgpdb.ucdavis.edu/GeneticMap & RGA \\
\hline LK0005-R & TGCATTCAGCTGCATTAGATT & 1 & http://cgpdb.ucdavis.edu/GeneticMap & RGA \\
\hline LK0010-F & AACATGTCTATGGGTTATATTGTCAT & 1 & http://cgpdb.ucdavis.edu/GeneticMap & RGA \\
\hline LK0010-R & AATGCATCCAATTGAGTAACAGT & 1 & http://cgpdb.ucdavis.edu/GeneticMap & RGA \\
\hline M1120-F & CGGAGGATGGAGGCAGAGACA & 1 & http://cgpdb.ucdavis.edu/GeneticMap & RGA \\
\hline M1120-R & CGTCTTCCCAATCCCACCCA & 1 & http://cgpdb.ucdavis.edu/GeneticMap & RGA \\
\hline CLX_S3_Contig9641-F & TTTGCCCTTGGTAACAGA & 1 & http://cgpdb.ucdavis.edu/GeneticMap & RGA \\
\hline CLX_S3_Contig9641-R & GGTATCCGCCTCCGCCGACAAC & 1 & http://cgpdb.ucdavis.edu/GeneticMap & RGA \\
\hline CLX_S3_Contig9641-F & GTTGTCGGCGGAGGCGGATAC & 1 & http://cgpdb.ucdavis.edu/GeneticMap & RGA \\
\hline CLX_S3_Contig9641-R & GTGGTTTGTCGTCGGATGGTGGTC & 1 & http://cgpdb.ucdavis.edu/GeneticMap & RGA \\
\hline CLX_S3_Contig9641-F & ACCCGACCACCATCCGACGACA & 1 & http://cgpdb.ucdavis.edu/GeneticMap & RGA \\
\hline CLX_S3_Contig9641-R & GGAAGTAACCCGCGAAATCAT & 1 & http://cgpdb.ucdavis.edu/GeneticMap & RGA \\
\hline CLX_S3_Contig9641-F & TGAAACTAACGATCGAGGACTACC & 1 & http://cgpdb.ucdavis.edu/GeneticMap & RGA \\
\hline CLX_S3_Contig9641-R & CGGGACCGGAAAATGGCTTGAG & 1 & http://cgpdb.ucdavis.edu/GeneticMap & RGA \\
\hline M1730-F & TGATCCAGGCTCTCCAGAAT & 1 & Simko et al. (2009) & SSR \\
\hline M1730-R & CACGACCATGAATGATAAGTGC & 1 & Simko et al. (2009) & SSR \\
\hline LK1117-F & TTGGATTTGGGGTGATGAAT & 1 & Simko et al. (2009) & SSR \\
\hline LK1117-R & GCATAGTAATTTGACATTTTGGCATA & 1 & Simko et al. (2009) & SSR \\
\hline
\end{tabular}




\begin{tabular}{|c|c|c|c|c|}
\hline LE1040-F & CATGAAGTGTTTTGGGGTGA & 1 & Simko et al. (2009) & SSR \\
\hline LE1040-R & GGCCTTTCATTTCTTCCTCA & 1 & Simko et al. (2009) & SSR \\
\hline CLX_S3_Contig8398-F & ATCACATTCATTCTCACGGGTCAA & 1 & http://cgpdb.ucdavis.edu/GeneticMap & RGA \\
\hline CLX_S3_Contig8398-R & CAGCACTGGCCTCGATTTACTTAC & 1 & http://cgpdb.ucdavis.edu/GeneticMap & RGA \\
\hline CLX_S3_Contig8398-F & TGGCGCCATGAGTGTCTT & 1 & http://cgpdb.ucdavis.edu/GeneticMap & RGA \\
\hline CLX_S3_Contig8398-R & CCGTTTTGTTGGGTTCTTGTTA & 1 & http://cgpdb.ucdavis.edu/GeneticMap & RGA \\
\hline CLX_S3_Contig8398-F & AGTTTACGCCTACCACAAG & 1 & http://cgpdb.ucdavis.edu/GeneticMap & RGA \\
\hline CLX_S3_Contig8398-R & TCTGACCCCGACCCGAACC & 1 & http://cgpdb.ucdavis.edu/GeneticMap & RGA \\
\hline CLX_S3_Contig8398-F & GGGTTATGGCGGGTTGTCTTATTC & 1 & http://cgpdb.ucdavis.edu/GeneticMap & RGA \\
\hline CLX_S3_Contig8398-R & GGTTTTCCCTCTGCTCTGTTTCAC & 1 & http://cgpdb.ucdavis.edu/GeneticMap & RGA \\
\hline CLX_S3_Contig8398-F & AGTCCGTGTTTCTGTCTTC & 1 & http://cgpdb.ucdavis.edu/GeneticMap & RGA \\
\hline CLX_S3_Contig8398-R & TGTCGCTAGCATAAAAATA & 1 & http://cgpdb.ucdavis.edu/GeneticMap & RGA \\
\hline CLX_S3_Contig3390-F & GAAAACTCCCTGCCGACATC & 1 & http://cgpdb.ucdavis.edu/GeneticMap & RGA \\
\hline CLX_S3_Contig3390-R & CAAGGGGAATTACCAAAACAGT & 1 & http://cgpdb.ucdavis.edu/GeneticMap & RGA \\
\hline QGF17I06-F & ATTGAATGCACCGAGTTTTTACCC & 1 & http://cgpdb.ucdavis.edu/GeneticMap & RGA \\
\hline QGF17I06-R & ACTTATCTATTCTCAACGCTTTTT & 1 & http://cgpdb.ucdavis.edu/GeneticMap & RGA \\
\hline LserNBS03 550-F & TATGATAGGATGAAAGCCACAAG & 1 & http://cgpdb.ucdavis.edu/GeneticMap & RGA \\
\hline LserNBS03 550-R & GAAGCCGAATAATAATCACAACTA & 1 & http://cgpdb.ucdavis.edu/GeneticMap & RGA \\
\hline CLSM741-F & AATTTGGTTTGACTTGAA & 1 & http://cgpdb.ucdavis.edu/GeneticMap & RGA \\
\hline CLSM741-R & ATCGCCCCATTGCTTTTA & 1 & http://cgpdb.ucdavis.edu/GeneticMap & RGA \\
\hline CLRY2600-F & TGTTTCTCACTTTTTCATCTGGTT & 1 & http://cgpdb.ucdavis.edu/GeneticMap & RGA \\
\hline CLRY2600-R & GTTTATTCTTTCGGGGCACAT & 1 & http://cgpdb.ucdavis.edu/GeneticMap & RGA \\
\hline CLSX3769-F & AATGCATTCCCCCGTAAGA & 1 & http://cgpdb.ucdavis.edu/GeneticMap & RGA \\
\hline CLSX3769-R & GGGTGAGGCCTAGAACATTT & 1 & http://cgpdb.ucdavis.edu/GeneticMap & RGA \\
\hline CLX_S3_Contig8409-F & TCCCGATAAAGACCCTGATGATG & 1 & http://cgpdb.ucdavis.edu/GeneticMap & RGA \\
\hline CLX_S3_Contig8409-R & TTTTCTCGATGTGGTGTGGTTTTA & 1 & http://cgpdb.ucdavis.edu/GeneticMap & RGA \\
\hline CLSY4446-F & ACAAAGGGCAAGTCAAAGGTAAG & 1 & http://cgpdb.ucdavis.edu/GeneticMap & RGA \\
\hline CLSY4446-R & GACACTCCAGCTAATTCTCCATCA & 1 & http://cgpdb.ucdavis.edu/GeneticMap & RGA \\
\hline CLX_S3_Contig1736-F & TGCGGCCATGGAACCTTTTAT & 1 & http://cgpdb.ucdavis.edu/GeneticMap & RGA \\
\hline CLX_S3_Contig1736-R & TCCGCATCTCCAGTCCATCCA & 1 & http://cgpdb.ucdavis.edu/GeneticMap & RGA \\
\hline CLRX9010-F & TACGATGGCTTCTCTTCTAAAAA & 1 & http://cgpdb.ucdavis.edu/GeneticMap & RGA \\
\hline CLRX9010-R & CGCGCAAAATACTTCAAAA & 1 & http://cgpdb.ucdavis.edu/GeneticMap & RGA \\
\hline CLX_S3_Contig3224-F & TTCAGAGTTTTCAAGTTTTCAGTC & 1 & http://cgpdb.ucdavis.edu/GeneticMap & RGA \\
\hline CLX_S3_Contig3224-R & CTTTTATGTTGGCCCTTAGAGAT & 1 & http://cgpdb.ucdavis.edu/GeneticMap & RGA \\
\hline CLX_S3_Contig9834-F & GGTTTTCTTCCCATACTCATCTCT & 1 & http://cgpdb.ucdavis.edu/GeneticMap & RGA \\
\hline CLX_S3_Contig9834-R & GTGTCGGTGTTGTAGGGTTTTCAG & 1 & http://cgpdb.ucdavis.edu/GeneticMap & RGA \\
\hline CLX_S3_Contig9834-F & AACCCTACAACACCGACACAACTA & 1 & http://cgpdb.ucdavis.edu/GeneticMap & RGA \\
\hline CLX_S3_Contig9834-R & TCGATCGTACTCACCAAAGAAAGA & 1 & http://cgpdb.ucdavis.edu/GeneticMap & RGA \\
\hline CLX_S3_Contig9834-F & CAGGAAGATGGAAGTAGG & 1 & http://cgpdb.ucdavis.edu/GeneticMap & RGA \\
\hline CLX_S3_Contig9834-R & TAAATCATGAGGAGTGGTAT & 1 & http://cgpdb.ucdavis.edu/GeneticMap & RGA \\
\hline CLX_S3_Contig579-F & TTGTCGGCGTTTCCTTCTCAG & 1 & http://cgpdb.ucdavis.edu/GeneticMap & RGA \\
\hline CLX_S3_Contig579-R & TGGCATATAATAAAAACAA & 1 & http://cgpdb.ucdavis.edu/GeneticMap & RGA \\
\hline $\begin{array}{l}\text { CLX_S3_Contig10397- } \\
\text { F }\end{array}$ & GAAGGAGGGGCCGAAGATGA & & http://cgpdb.ucdavis.edu/GeneticMap & RGA \\
\hline $\begin{array}{l}\text { CLX_S3_Contig10397- } \\
\text { R }\end{array}$ & CCGATTAAAACCGCTAGGAACAGA & & http://cgpdb.ucdavis.edu/GeneticMap & RGA \\
\hline $\begin{array}{l}\text { CLX_S3_Contig15606- } \\
\text { F }\end{array}$ & CGGGGATAAGAAACACCTC & & http://cgpdb.ucdavis.edu/GeneticMap & RGA \\
\hline
\end{tabular}




\begin{tabular}{|c|c|c|c|c|}
\hline $\begin{array}{l}\text { CLX_S3_Contig15606- } \\
\text { R }\end{array}$ & TCAACAAAGACTCGACCCCATCAG & 1 & http://cgpdb.ucdavis.edu/GeneticMap & RGA \\
\hline CLRX1526-F & CTTTCATTCATTGCCATCTAACA & 1 & http://cgpdb.ucdavis.edu/GeneticMap & RGA \\
\hline CLRX1526-R & TACTATAACAGCCGACAAAT & 1 & http://cgpdb.ucdavis.edu/GeneticMap & RGA \\
\hline CLX_S3_Contig1828-F & AGCCCAAACTTCTCCCACAACAC & 1 & http://cgpdb.ucdavis.edu/GeneticMap & RGA \\
\hline CLX_S3_Contig1828-R & AAAATACAATCAAACAAATACAGA & 1 & http://cgpdb.ucdavis.edu/GeneticMap & RGA \\
\hline Contig-6125-F & TGGTTTTGGTGTGTTTGACC & 1 & http://cgpdb.ucdavis.edu/GeneticMap & RGA \\
\hline Contig-6125-R & TACGTTGGCAACAGCCATTA & 1 & http://cgpdb.ucdavis.edu/GeneticMap & RGA \\
\hline LE0238-F & GCTTCTGATTGGTTTGTGGG & 2 & http://cgpdb.ucdavis.edu/GeneticMap & RGA \\
\hline LE0238-R & TGCCGTATCAATGGAGTTCA & 2 & http://cgpdb.ucdavis.edu/GeneticMap & RGA \\
\hline LR0049-F & CGAGGAGTTGATGAGGTATGG & 2 & http://cgpdb.ucdavis.edu/GeneticMap & RGA \\
\hline LR0049-R & TCAGTCCACTCGGGCATATT & 2 & http://cgpdb.ucdavis.edu/GeneticMap & RGA \\
\hline LR0035-F & GTGGGGAAGACGACAATGAT & 2 & http://cgpdb.ucdavis.edu/GeneticMap & RGA \\
\hline LR0035-R & CCACAAACTGCCATACATCG & 2 & http://cgpdb.ucdavis.edu/GeneticMap & RGA \\
\hline LE0213-F & CGTGATTGTTCAGGATGCAG & 2 & http://cgpdb.ucdavis.edu/GeneticMap & RGA \\
\hline LE0213-R & TGTAGCTCTTGGAGTTGCGA & 2 & http://cgpdb.ucdavis.edu/GeneticMap & RGA \\
\hline LR0031-F & AGGGATTGTTGGTGCCATT & 2 & http://cgpdb.ucdavis.edu/GeneticMap & RGA \\
\hline LR0031-R & GTTTGCAACATTCGCTCTGA & 2 & http://cgpdb.ucdavis.edu/GeneticMap & RGA \\
\hline LR0029-F & GGAAGTGCAGCAACTGGAAT & 2 & http://cgpdb.ucdavis.edu/GeneticMap & RGA \\
\hline LR0029-R & AGGGAACAAAGTGGTGGTTG & 2 & http://cgpdb.ucdavis.edu/GeneticMap & RGA \\
\hline LR0089-F & GCACTTGAAAGCCTGACACA & 2 & http://cgpdb.ucdavis.edu/GeneticMap & RGA \\
\hline LR0089-R & TTCTTCCAATGAAGGCAACC & 2 & http://cgpdb.ucdavis.edu/GeneticMap & RGA \\
\hline LE0224-F & TGCTTCCATGGTCAATCTCA & 2 & http://cgpdb.ucdavis.edu/GeneticMap & RGA \\
\hline LE0224-R & CCACAACTGAGATGGGAGGT & 2 & http://cgpdb.ucdavis.edu/GeneticMap & RGA \\
\hline LE0314-F & GAAACGGCTCCGATTGTTA & 2 & http://cgpdb.ucdavis.edu/GeneticMap & RGA \\
\hline LE0314-R & GATTCCAGGATCTGATGCGT & 2 & http://cgpdb.ucdavis.edu/GeneticMap & RGA \\
\hline LE0115-F & ACTGCTCCACTACCCACCAC & 2 & http://cgpdb.ucdavis.edu/GeneticMap & RGA \\
\hline LE0115-R & CGACAAGGCTGACATCGTAA & 2 & http://cgpdb.ucdavis.edu/GeneticMap & RGA \\
\hline LE3172-F & TTCTTTCGCCCATCTGAAAC & 2 & Simko et al. (2009) & SSR \\
\hline LE3172-R & AAACAGGGGGCTAACGATCT & 2 & Simko et al. (2009) & SSR \\
\hline LE3093-F & GGGTTCTCATTGGCTGACAT & 2 & Simko et al. (2009) & SSR \\
\hline LE3093-R & TGTCTTCCAACCAAAACATACA & 2 & Simko et al. (2009) & SSR \\
\hline CLX_S3_Contig4455-F & GCGCTTCAATTCATCGGTTTTCTA & 2 & http://cgpdb.ucdavis.edu/GeneticMap & RGA \\
\hline CLX_S3_Contig4455-R & TTCTTGCCCCTCCGTTGATTTCTT & 2 & http://cgpdb.ucdavis.edu/GeneticMap & RGA \\
\hline $\begin{array}{l}\text { CLX_S3_Contig14182- } \\
\text { F }\end{array}$ & СТTCСТTTTCCTATCCATCAGTTT & 2 & http://cgpdb.ucdavis.edu/GeneticMap & RGA \\
\hline $\begin{array}{l}\text { CLX_S3_Contig14182- } \\
\mathrm{R}\end{array}$ & ATAATTAATACATCAAGGGCAGAA & 2 & http://cgpdb.ucdavis.edu/GeneticMap & RGA \\
\hline $\begin{array}{l}\text { CLX_S3_Contig11288 - } \\
\text { F }\end{array}$ & CACCATCATTAGACGAAAGACAAG & 2 & http://cgpdb.ucdavis.edu/GeneticMap & RGA \\
\hline $\begin{array}{l}\text { CLX_S3_Contig11288- } \\
\text { R }\end{array}$ & GCATGATAAAAAGCTGAAAAGGTA & 2 & http://cgpdb.ucdavis.edu/GeneticMap & RGA \\
\hline $\begin{array}{l}\text { CLX_S3_Contig12930- } \\
\text { F }\end{array}$ & AGTGGCCCTATGATTGTGACG & 2 & http://cgpdb.ucdavis.edu/GeneticMap & RGA \\
\hline $\begin{array}{l}\text { CLX_S3_Contig12930- } \\
\text { R }\end{array}$ & CATTGGCGACTTCCCTCCTC & 2 & http://cgpdb.ucdavis.edu/GeneticMap & RGA \\
\hline CLX_S3_Contig3045-F & ACTACGGCCCATCAATCCCACCTC & 2 & http://cgpdb.ucdavis.edu/GeneticMap & RGA \\
\hline CLX_S3_Contig3045-R & AATGAACCAATAATCCCGAAAAAT & 2 & http://cgpdb.ucdavis.edu/GeneticMap & RGA \\
\hline CLX_S3_Contig9978-F & AАCCAATCTTTTCCCAACAA & 2 & http://cgpdb.ucdavis.edu/GeneticMap & RGA \\
\hline CLX_S3_Contig9978-R & ATGAATATGCAGCCAACAGACCA & 2 & http://cgpdb.ucdavis.edu/GeneticMap & RGA \\
\hline WF25-F & GAGCAATTGATACATACCTGCAACATTGTT & 2 & Aruga et al. (2012) & SCAR \\
\hline
\end{tabular}




\begin{tabular}{|c|c|c|c|c|}
\hline WF25-R & GGAGGGGCAATAAGAACATTTGCTCTT & 2 & Aruga et al. (2012) & SCAR \\
\hline LE0491A-F & CATTACAACAAGAGATGAGCAAGTG & 4 & http://cgpdb.ucdavis.edu/GeneticMap & RGA \\
\hline LE0491A-R & GGCATCTACCCATTCAGGTTT & 4 & http://cgpdb.ucdavis.edu/GeneticMap & RGA \\
\hline LE0189B-F & GCGAAGATGCAGAAGATGGA & 4 & http://cgpdb.ucdavis.edu/GeneticMap & RGA \\
\hline LE0189B-R & AGGCCATAACAATCTCACCG & 4 & http://cgpdb.ucdavis.edu/GeneticMap & RGA \\
\hline M493-F & GGGTTAAGAGGATGTTACAACC & 4 & http://cgpdb.ucdavis.edu/GeneticMap & RGA \\
\hline M493-R & TTCACACCAAGCAAAAACTC & 4 & http://cgpdb.ucdavis.edu/GeneticMap & RGA \\
\hline LE0279-F & ATTGAGGGCAATGAGGTGAC & 4 & http://cgpdb.ucdavis.edu/GeneticMap & RGA \\
\hline LE0279-R & AGAAACACGGGACTTGATGG & 4 & http://cgpdb.ucdavis.edu/GeneticMap & RGA \\
\hline LE0053-F & ATACACCCGCCACCTGTAAA & 4 & http://cgpdb.ucdavis.edu/GeneticMap & RGA \\
\hline LE0053-R & ATAATCTGCCCCAGTGCAAG & 4 & http://cgpdb.ucdavis.edu/GeneticMap & RGA \\
\hline LE0337-F & CCATGGCTAAAAAGCAAACC & 4 & http://cgpdb.ucdavis.edu/GeneticMap & RGA \\
\hline LE0337-R & ACATTAGCCAAGCGACAACA & 4 & http://cgpdb.ucdavis.edu/GeneticMap & RGA \\
\hline LE0126-F & AGGAGGCTGCTAGGGCTTAC & 4 & http://cgpdb.ucdavis.edu/GeneticMap & RGA \\
\hline LE0126-R & ACTAGCAGACTGCCGGAAAA & 4 & http://cgpdb.ucdavis.edu/GeneticMap & RGA \\
\hline LE0351-F & GAATATGCGGCGGAGATAAG & 4 & http://cgpdb.ucdavis.edu/GeneticMap & RGA \\
\hline LE0351-R & AATCACATGAATGGATGCAAA & 4 & http://cgpdb.ucdavis.edu/GeneticMap & RGA \\
\hline LE0241-F & ACACAACTTTGGGAAGACGG & 4 & http://cgpdb.ucdavis.edu/GeneticMap & RGA \\
\hline LE0241-R & GTAGGGACTTGGCTGTCAGG & 4 & http://cgpdb.ucdavis.edu/GeneticMap & RGA \\
\hline LE0402-F & ACGACTGGAGCAGGTGAAAC & 4 & http://cgpdb.ucdavis.edu/GeneticMap & RGA \\
\hline LE0402-R & CAAGTTTTGTGCAAGGCTGA & 4 & http://cgpdb.ucdavis.edu/GeneticMap & RGA \\
\hline LE0463-F & TTGGGTTCAGGAAAGACCAC & 7 & http://cgpdb.ucdavis.edu/GeneticMap & RGA \\
\hline LE0463-R & CTCAAAACGTCGTCGTCAGA & 7 & http://cgpdb.ucdavis.edu/GeneticMap & RGA \\
\hline LK1425-F & CCGACGGAAACCTTGTACTG & 7 & http://cgpdb.ucdavis.edu/GeneticMap & RGA \\
\hline LK1425-R & GTATTCGGTTTCCACGATGC & 7 & http://cgpdb.ucdavis.edu/GeneticMap & RGA \\
\hline M6982-F & GCACCGTTGAGTCGGGTA & 7 & http://cgpdb.ucdavis.edu/GeneticMap & RGA \\
\hline M6982-R & AGAACGGATCCGTCCAATCT & 7 & http://cgpdb.ucdavis.edu/GeneticMap & RGA \\
\hline LE0157-F & CGGACAATGCTGATGTATCC & 7 & http://cgpdb.ucdavis.edu/GeneticMap & RGA \\
\hline LE0157-R & AAATTCAAATGCTATCGGGC & 7 & http://cgpdb.ucdavis.edu/GeneticMap & RGA \\
\hline LE0024-F & CTTGCTGACAGAATGCCAGA & 7 & http://cgpdb.ucdavis.edu/GeneticMap & RGA \\
\hline LE0024-R & TCTCTCСАCTCCCATGATCC & 7 & http://cgpdb.ucdavis.edu/GeneticMap & RGA \\
\hline M4241-F & GTACTTTTACTTGCCGAGAAGCC & 7 & http://cgpdb.ucdavis.edu/GeneticMap & RGA \\
\hline M4241-R & GTGGCCATACATATATAGCAACCA & 7 & http://cgpdb.ucdavis.edu/GeneticMap & RGA \\
\hline M6982-F & GCACCGTTGAGTCGGGTA & 7 & http://cgpdb.ucdavis.edu/GeneticMap & RGA \\
\hline M6982-R & AGAACGGATCCGTCCAATCT & 7 & http://cgpdb.ucdavis.edu/GeneticMap & RGA \\
\hline LE3164-F & CTTCGGTCTGGAGAGTGGTC & 7 & http://cgpdb.ucdavis.edu/GeneticMap & RGA \\
\hline LE3164-R & CAGAGGCCTCCCAAATATCA & 7 & http://cgpdb.ucdavis.edu/GeneticMap & RGA \\
\hline LE3180-F & CCAGCTATGTGGGACCCTAA & 7 & http://cgpdb.ucdavis.edu/GeneticMap & RGA \\
\hline LE3180-R & CCAACAGCCCAACACACTTT & 7 & http://cgpdb.ucdavis.edu/GeneticMap & RGA \\
\hline LK1425-F & CCGACGGAAACCTTGTACTG & 7 & http://cgpdb.ucdavis.edu/GeneticMap & RGA \\
\hline LK1425-R & GTATTCGGTTTCCACGATGC & 7 & http://cgpdb.ucdavis.edu/GeneticMap & RGA \\
\hline CLSM11140-F & GAAAACCTCCCATTACG & 7 & http://cgpdb.ucdavis.edu/GeneticMap & RGA \\
\hline CLSM11140-R & ATCAGACTAGGAAACAAGACT & 7 & http://cgpdb.ucdavis.edu/GeneticMap & RGA \\
\hline CLX_S3_Contig2031-F & AGTGTTATTCATCTTCGTCAT & 7 & http://cgpdb.ucdavis.edu/GeneticMap & RGA \\
\hline CLX_S3_Contig2031-R & АTTTCTCTTTATTTATAGTCATCT & 7 & http://cgpdb.ucdavis.edu/GeneticMap & RGA \\
\hline $\begin{array}{l}\text { CLX_S3_Contig13351- } \\
\text { F }\end{array}$ & ATAACTAAATGATGGAAGAAAG & 7 & http://cgpdb.ucdavis.edu/GeneticMap & RGA \\
\hline
\end{tabular}




\begin{tabular}{|c|c|c|c|c|}
\hline $\begin{array}{l}\text { CLX_S3_Contig13351- } \\
\mathrm{R}\end{array}$ & GAAACAGTTATGCATGGGAATCA & 7 & http://cgpdb.ucdavis.edu/GeneticMap & RGA \\
\hline $\begin{array}{l}\text { CLX_S3_Contig15074- } \\
\text { F }\end{array}$ & CGTGTTGCGGGTTCTTCC & 7 & http://cgpdb.ucdavis.edu/GeneticMap & RGA \\
\hline $\begin{array}{l}\text { CLX_S3_Contig15074- } \\
\text { R }\end{array}$ & GACGCATTTTTCTCCATTATTTTT & 7 & http://cgpdb.ucdavis.edu/GeneticMap & RGA \\
\hline CLX_S3_Contig2349-F & ССАСААТТССТСТТСТСАСТССАТ & 7 & http://cgpdb.ucdavis.edu/GeneticMap & RGA \\
\hline CLX_S3_Contig2349-R & TGTATCAGCTTCCACCATCCT & 7 & http://cgpdb.ucdavis.edu/GeneticMap & RGA \\
\hline M1981-F & GCAAGATGTTGACCAAGTCG & 7 & http://cgpdb.ucdavis.edu/GeneticMap & RGA \\
\hline M1981-R & CGTGGTCAAACACACCAAAA & 7 & http://cgpdb.ucdavis.edu/GeneticMap & RGA \\
\hline LE-3180-F & TCTAAGGGGGTGTGATCTGG & 7 & http://cgpdb.ucdavis.edu/GeneticMap & RGA \\
\hline LE-3180-R & CCAACAGCCCAACACACTTT & 7 & http://cgpdb.ucdavis.edu/GeneticMap & RGA \\
\hline LE0414-F & CGATTGGGAACACATGTCAG & 8 & http://cgpdb.ucdavis.edu/GeneticMap & RGA \\
\hline LE0414-R & TCCTAAAGAACCACGCAACG & 8 & http://cgpdb.ucdavis.edu/GeneticMap & RGA \\
\hline LE0387-F & TCGATTCCAAGGTCATTGTG & 8 & http://cgpdb.ucdavis.edu/GeneticMap & RGA \\
\hline LE0387-R & TTCAACTCCCCTAGGCAATG & 8 & http://cgpdb.ucdavis.edu/GeneticMap & RGA \\
\hline LE0388-F & AAACTGAGTTACGGTTGATAATGG & 8 & http://cgpdb.ucdavis.edu/GeneticMap & RGA \\
\hline LE0388-R & AAAGTTCGATCCCGAACTAAGA & 8 & http://cgpdb.ucdavis.edu/GeneticMap & RGA \\
\hline LE0248-F & TGCCGATTCATATGGTGTTC & 8 & http://cgpdb.ucdavis.edu/GeneticMap & RGA \\
\hline LE0248-R & TTGGAAAGTCCACAACCACA & 8 & http://cgpdb.ucdavis.edu/GeneticMap & RGA \\
\hline LE0395-F & GCGTGATGTCGCTTTGTTAAT & 8 & http://cgpdb.ucdavis.edu/GeneticMap & RGA \\
\hline LE0395-R & ACAGTGAGTGTGTCGCAAGG & 8 & http://cgpdb.ucdavis.edu/GeneticMap & RGA \\
\hline LE0206-F & GTTCCTTGGCTGGAACTCTG & 8 & http://cgpdb.ucdavis.edu/GeneticMap & RGA \\
\hline LE0206-R & TTGCCCTTGGTGAAAGTCAT & 8 & http://cgpdb.ucdavis.edu/GeneticMap & RGA \\
\hline LM0035-F & TCCTGATCCCAACAACAGTG & 8 & http://cgpdb.ucdavis.edu/GeneticMap & RGA \\
\hline LM0035-R & AGGGGGTCGGAAAAACAAT & 8 & http://cgpdb.ucdavis.edu/GeneticMap & RGA \\
\hline LE0225B-F & TTGCAACTTGATACCGCAAA & 8 & http://cgpdb.ucdavis.edu/GeneticMap & RGA \\
\hline LE0225B-R & TACAGTGGTTGGATGTGGGA & 8 & http://cgpdb.ucdavis.edu/GeneticMap & RGA \\
\hline LE0457-F & GAGGCATTGTGGAAGACGAC & 8 & http://cgpdb.ucdavis.edu/GeneticMap & RGA \\
\hline LE0457-R & GCAAGCTCTTCGTACCCTTG & 8 & http://cgpdb.ucdavis.edu/GeneticMap & RGA \\
\hline LE0178-F & TTGCTGACATAAGAGAAGTTTCAA & 8 & http://cgpdb.ucdavis.edu/GeneticMap & RGA \\
\hline LE0178-R & ATGTGACAGCAGCCCTTTCT & 8 & http://cgpdb.ucdavis.edu/GeneticMap & RGA \\
\hline
\end{tabular}


Tabela 3-2. Resultados das buscas (via o algoritmo BLAST) de identidade das sequências dos amplicons derivados de um subgrupo de primers empregados, visando identificar marcadores ligados e/ou genes candidatos associados com a resistência a FOLAC raça 1 em alface. Esses marcadores foram derivados de sequencias do tipo Resistance gene analogs (RGAs) estão dispersos em cinco dos principais MRCs (major resistance clusters) do genoma da alface localizados nos cromossomos (Cr.)/grupos de ligação 1, 2, 4, 7 \& 8 .

\begin{tabular}{|c|c|c|c|}
\hline $\mathrm{Cr}$ & Código dos primers & Identidade Blast & Temp. anel. \\
\hline 1 & LE0261 & Leucine-rich repeats (LRRs) & $60^{\circ} \mathrm{C}$ \\
\hline 1 & LE0243 & Leucine-rich repeats (LRRs) & $62{ }^{\circ} \mathrm{C}$ \\
\hline 1 & LE0229 & & $60^{\circ} \mathrm{C}$ \\
\hline 1 & LE0193 & & $60^{\circ} \mathrm{C}$ \\
\hline 1 & M1120 & & $52{ }^{\circ} \mathrm{C}$ \\
\hline 1 & LE0187 & & $60^{\circ} \mathrm{C}$ \\
\hline 1 & LE0427 & & $52{ }^{\circ} \mathrm{C}$ \\
\hline 1 & LK0005 & $\mathrm{RVK}$ resistance protein candidate gene & $60{ }^{\circ} \mathrm{C}$ \\
\hline 1 & LK0005 & $\mathrm{RVK}$ resistance protein candidate gene & $52^{\circ} \mathrm{C}$ \\
\hline 1 & CLRX9010 & flowering locus $\mathrm{T}(\mathrm{FT})$ gene & $56^{\circ} \mathrm{C}$ \\
\hline 1 & CLRY-2600 & Guasihong cellulase (CEL1) mRNA & $58^{\circ} \mathrm{C}$ \\
\hline 1 & CLSM-741 & NBD_sugar-kinase_HSP70-actin & $54{ }^{\circ} \mathrm{C}$ \\
\hline 1 & CLSX3769 & NBS-LRR resistance-like protein $4 \mathrm{~W}$ gene & $54{ }^{\circ} \mathrm{C}$ \\
\hline 1 & CLSY4446 & Chloroplast ndhF gene for NADH dehydrogenase subunit F & $54{ }^{\circ} \mathrm{C}$ \\
\hline 1 & CLX_S3_Contig1828 & Resistance protein $\mathrm{RGC} 2$ (RGC2) gene & $54{ }^{\circ} \mathrm{C}$ \\
\hline 1 & CLX_S3_Contig9641-2Ve 2G & LsGID1B mRNA for GA Insensitive Dwarf1 B (Lipoxygenase) & $54^{\circ} \mathrm{C}$ \\
\hline 1 & CLX_S3_Contig9641-3Ve 3G & Arginine methyltransferase 6 mRNA (Lipoxygenase) & $54^{\circ} \mathrm{C}$ \\
\hline 1 & CLX_S3_Contig9641-Ve G & Cysteine-rich RLK, nine-cis-epoxycarotenoid (Lipoxygenase) & $54{ }^{\circ} \mathrm{C}$ \\
\hline 1 & QGF17/06 & Cysteine-rich RLK, nine-cis-epoxycarotenoid (Cap-N super family) & $60^{\circ} \mathrm{C}$ \\
\hline 1 & CLX_S3_Contig3390 & Flowering locus $\mathrm{T}(\mathrm{FT})$ gene & $54^{\circ} \mathrm{C}$ \\
\hline 1 & CLX_S3_Contig8398 3V e $3 \mathrm{C}$ & Flowering locus $\mathrm{T}(\mathrm{FT})$ gene & $66^{\circ} \mathrm{C}$ \\
\hline 1 & CLX_S3_Contig8398-5V e 5G & Cysteine-rich RLK, nine-cis-epoxycarotenoid & $62{ }^{\circ} \mathrm{C}$ \\
\hline 1 & CLX_S3_Contig8398-6V e 6 G & Cysteine-rich RLK, nine-cis-epoxycarotenoid dioxygenase 4 & $58^{\circ} \mathrm{C}$ \\
\hline 1 & CLX_S3_Contig8398 & Resistance protein candidate RGC2B (RGC2B) gene, & $50{ }^{\circ} \mathrm{C}$ \\
\hline 1 & CLX_S3_Contig8409 & Bushy growth protein mRNA & $50^{\circ} \mathrm{C}$ \\
\hline 1 & CLX_S3_Contig9834 & Protein, cysteine-rich RLK, nine-cis-epoxycarotenoid dioxygenase 4 & $54^{\circ} \mathrm{C}$ \\
\hline 1 & CLX_S3_Contig10397 & Lactuca sativa clone TM10 resistance protein RGC2 (RGC2) & $54{ }^{\circ} \mathrm{C}$ \\
\hline 1 & LE 172 & NBS-LRR resistance-like protein RGC1G gene & $62^{\circ} \mathrm{C}$ \\
\hline 1 & LserNBS03 & Clone TDM resistance protein RGC2 ( $\mathrm{RGC} 2$ ) gene & $66^{\circ} \mathrm{C}$ \\
\hline 1 & M1730 & Microsatellite LSSB56 sequence & $66^{\circ} \mathrm{C}$ \\
\hline 1 & LE1040 & tRNA-Lys gene, photosystem II D1 protein (psbA) gene, & $52^{\circ} \mathrm{C}$ \\
\hline 1 & LK1117 & Microsatellite LSSB57-1 & $54^{\circ} \mathrm{C}$ \\
\hline 2 & LE0238 & Resistance protein candidate $\mathrm{RGC} 2 \mathrm{C}$ ( $\mathrm{RGC} 2 \mathrm{C}$ ) gene & $52^{\circ} \mathrm{C}$ \\
\hline 2 & LR0049 & Resistance protein candidate RGC2S (RGC2S) gene & $52^{\circ} \mathrm{C}$ \\
\hline
\end{tabular}




\begin{tabular}{|c|c|c|c|}
\hline 2 & LR0035 & & $58^{\circ} \mathrm{C}$ \\
\hline 2 & LE0314 & Hs1pro-1 protein C-terminus & $58^{\circ} \mathrm{C}$ \\
\hline 2 & LE0115 & & $60^{\circ} \mathrm{C}$ \\
\hline 2 & LR0031 & & $58^{\circ} \mathrm{C}$ \\
\hline 2 & LR0029 & Resistance protein candidate RGC2J (RGC2J) gene & $58^{\circ} \mathrm{C}$ \\
\hline 2 & LR0089 & & $60^{\circ} \mathrm{C}$ \\
\hline 2 & CLX_S3_Contig14182 & Flowering locus $\mathrm{T}(\mathrm{FT})$ gene & $50^{\circ} \mathrm{C}$ \\
\hline 2 & CLX_S3_Contig3045 & Clone TDH resistance protein RGC2 (RGC2) gene & $60^{\circ} \mathrm{C}$ \\
\hline 2 & CLX_S3_Contig4455 & TDM resistance protein RGC2 (RGC2) gene & $58^{\circ} \mathrm{C}$ \\
\hline 2 & CLX_S3_Contig11288 & Cysteine-rich RLK, nine-cis-epoxycarotenoid dioxygenase 4 & $60{ }^{\circ} \mathrm{C}$ \\
\hline 2 & CLX_S3_Contig12930 & 15-cis-zeta-carotene isomerase mRNA & $60^{\circ} \mathrm{C}$ \\
\hline 4 & LE0491 & NB-ARC domain & $60{ }^{\circ} \mathrm{C}$ \\
\hline 4 & LE0189B & Leucine Rich repeats & $50{ }^{\circ} \mathrm{C}$ \\
\hline 4 & LE0279 & & $52{ }^{\circ} \mathrm{C}$ \\
\hline 4 & LE0053 & & $50{ }^{\circ} \mathrm{C}$ \\
\hline 4 & LE0337 & PP01_KFDV superfamily- & $58^{\circ} \mathrm{C}$ \\
\hline 4 & LE0126 & DNA-binding domain (APETALA2) & $56^{\circ} \mathrm{C}$ \\
\hline 4 & LE0351 & Leucine-rich repeat receptor-like protein kinase & $56^{\circ} \mathrm{C}$ \\
\hline 4 & LE0241 & & $54{ }^{\circ} \mathrm{C}$ \\
\hline 4 & LE0402 & & $50^{\circ} \mathrm{C}$ \\
\hline 7 & M4241 & TDH resistance protein RGC2 (RGC2) gene & $62{ }^{\circ} \mathrm{C}$ \\
\hline 7 & LE3164 & & $58^{\circ} \mathrm{C}$ \\
\hline 7 & LE0024 & & $62{ }^{\circ} \mathrm{C}$ \\
\hline 7 & LE3180 & Phosphate-induced protein 1 conserved region & $62{ }^{\circ} \mathrm{C}$ \\
\hline 7 & LE0157 & Dolichyl -phosphate-mannose-protein mannossyltransferase. & $60^{\circ} \mathrm{C}$ \\
\hline 7 & M6982 & & $62{ }^{\circ} \mathrm{C}$ \\
\hline 7 & LE0463 & NB-ARC domain & $62{ }^{\circ} \mathrm{C}$ \\
\hline 7 & CLSM11140 & NADPH-protochlorophyllide oxidoreductase mRNA & $58^{\circ} \mathrm{C}$ \\
\hline 7 & M1981 & Clone 6-1 putative cellulose synthase (CesA) gene & $54{ }^{\circ} \mathrm{C}$ \\
\hline 7 & CLX_S3_Conting2031 & Flowering locus $\mathrm{T}(\mathrm{FT})$ gene & $54{ }^{\circ} \mathrm{C}$ \\
\hline 7 & CLX_S3_Conting2349 & Flowering locus T (FT) gene & $62{ }^{\circ} \mathrm{C}$ \\
\hline 7 & CLX_S3_Conting15074 & Cysteine-rich RLK, nine-cis- & $60^{\circ} \mathrm{C}$ \\
\hline 8 & LE414 & Leucine-rich repeat receptor-like protein kinase & $54{ }^{\circ} \mathrm{C}$ \\
\hline 8 & LE0387 & & $54^{\circ} \mathrm{C}$ \\
\hline 8 & LE0388 & & $54{ }^{\circ} \mathrm{C}$ \\
\hline 8 & LE0248 & & $50^{\circ} \mathrm{C}$ \\
\hline 8 & LE0395 & & $60^{\circ} \mathrm{C}$ \\
\hline 8 & LE0225B & Cysteine-rich RLK, nine-cis-epoxycarotenoid & $54{ }^{\circ} \mathrm{C}$ \\
\hline 8 & LE0457 & & $60^{\circ} \mathrm{C}$ \\
\hline 8 & LE0178 & RVK resistance protein candidate gene & $54{ }^{\circ} \mathrm{C}$ \\
\hline 8 & LM0035 & & $52^{\circ} \mathrm{C}$ \\
\hline
\end{tabular}


Tabela 3-3. Recombinantes encontrados na análise dos marcadores moleculares testados em indivíduos da população $F_{2}$ de alface.

\begin{tabular}{cccc}
\hline Cromossomos & Marcadores & Recombinantes & \% \\
\hline 8 & LE0395 & $17 / 70$ & 24 \\
7 & LE3164 & $26 / 52$ & 50 \\
8 & LM0035 & $33 / 82$ & 40 \\
4 & LE0337 & $10 / 16$ & 62 \\
4 & LE0351 & $10 / 26$ & 38 \\
7 & M4241 & $18 / 28$ & 64 \\
\hline
\end{tabular}




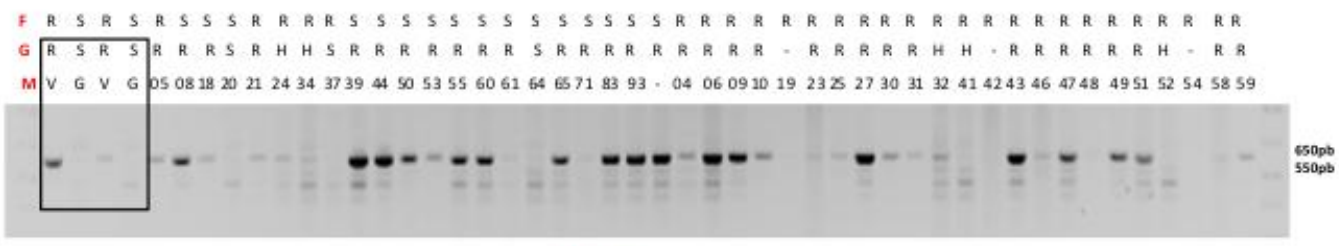

LE3164

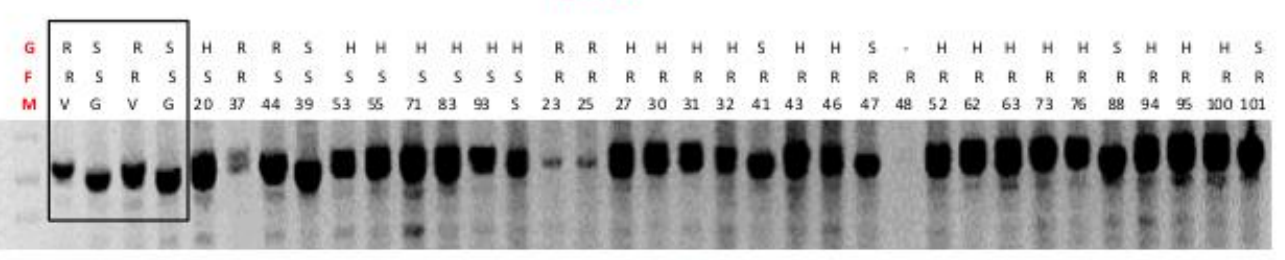

CAPS LE0337/BsTN1

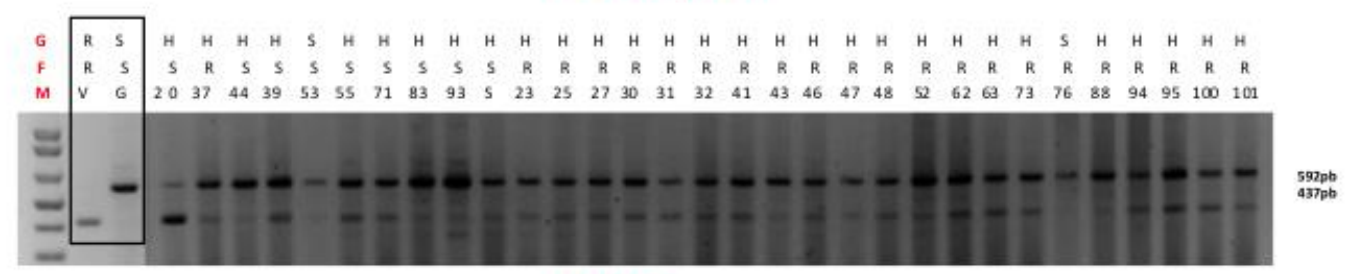

LM0035

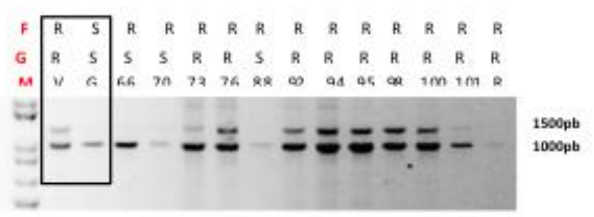

CAPS LE0351/MspA1

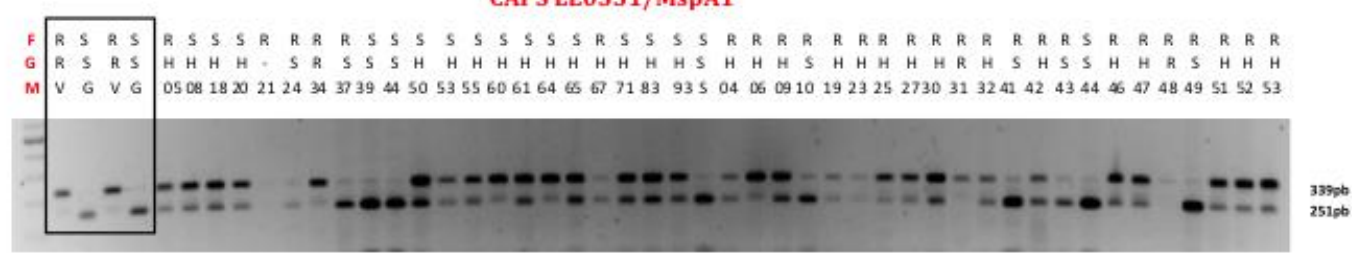

CAPSM4241/Mse1

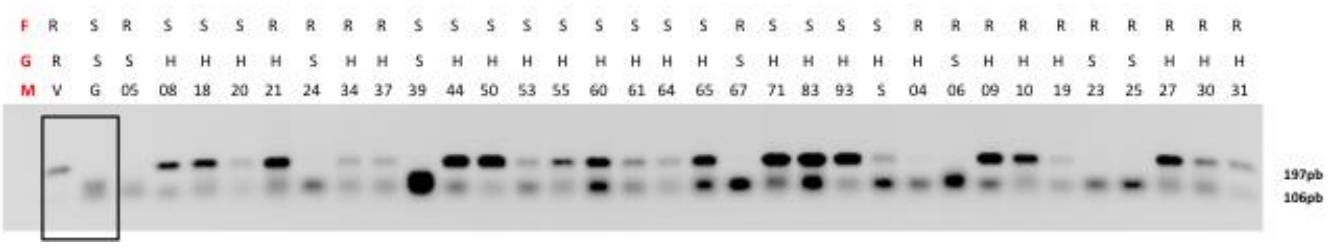

Figura 3-1. Padrão de amplicons gerado pelos primers testados. Análise em gel de agarose 1,5\%. MM Marcador Molecular 1Kb Plus DNA Ladder (Invitrogen). F: fenótipo de alface (Lactuca sativa L.) observado (resistente ou suscetivel). G: Genotipagem pelo marcador em questão considerando R o padrão da cultivar 'Vanda' (V) e S o padrão da cultivar 'Gizele' (G) e padrão heterozigoto $(\mathrm{H})$. 


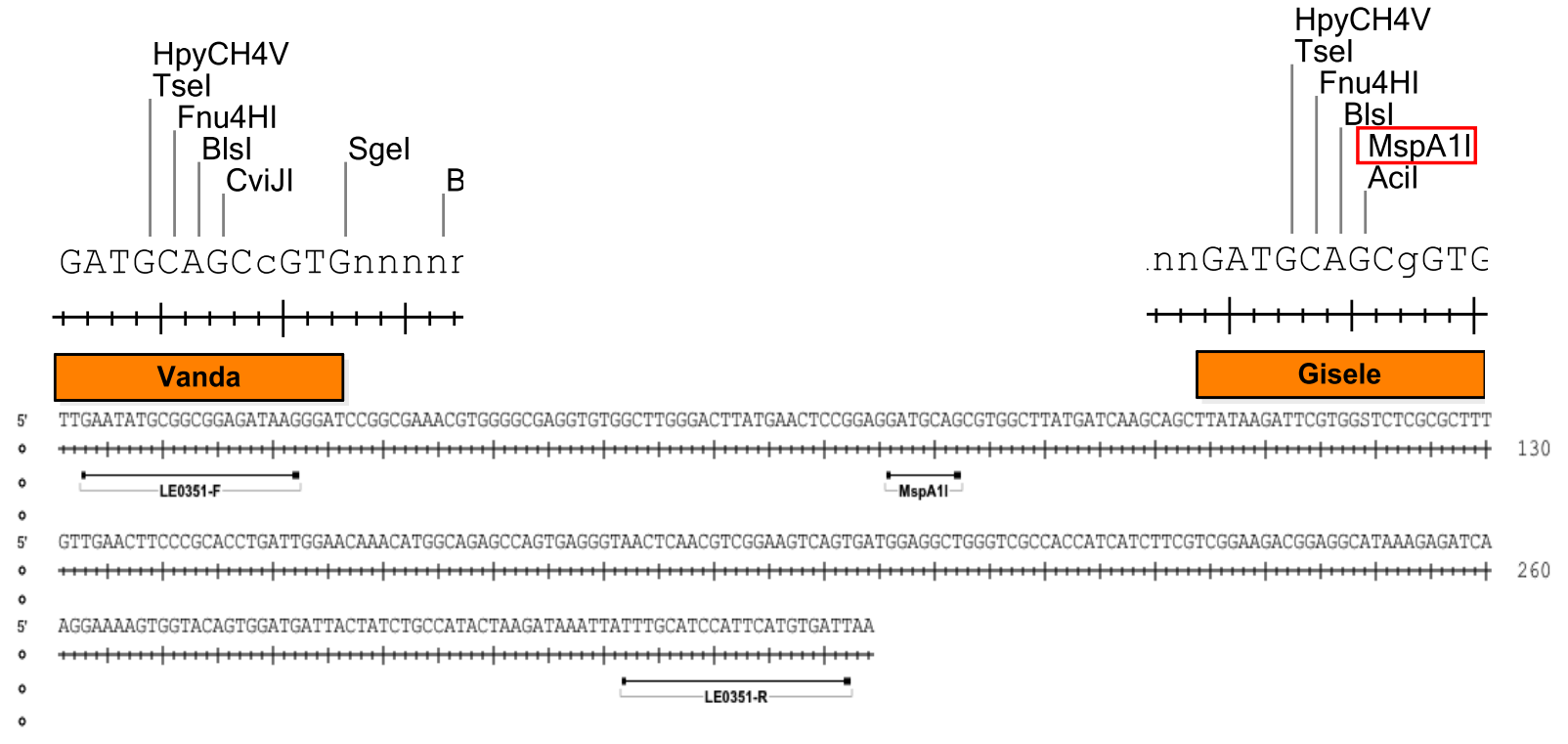

Figura 3-2. Desenho de um marcador CAPS (Cleaved Amplified Polymorphic Sequence) baseado na sequência obtida pela amplificação com o primer LE0351. Abaixo a sequência obtida após amplificação da cultivar de alface (Lactuca sativa L.) 'Gizele' com o sítio de restrição da enzima MspA1. Acima o segmento mostrando o mapa de restrição para o amplicon de 'Vanda' (sem MspA1) e 'Gizele' (com MspA1). 


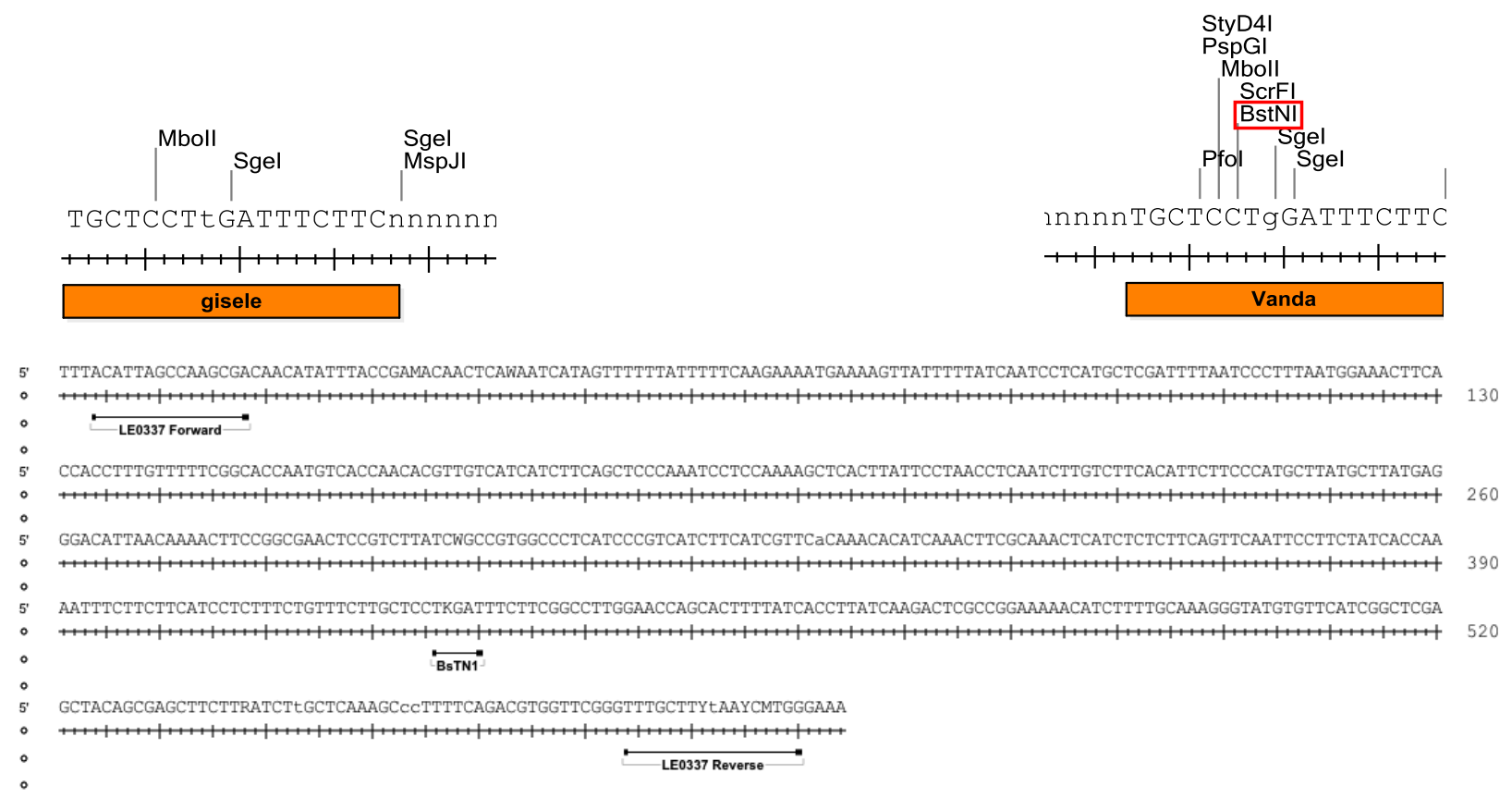

Figura 3-3. Desenho de um marcador CAPS (Cleaved Amplified Polymorphic Sequence) baseado na sequência obtida pela amplificação com o primer LE0337. Abaixo a sequência obtida após amplificação da cultivar de alface (Lactuca sativa L.) 'Vanda' com o sítio de restrição da enzima BstN1. Acima o segmento mostrando o mapa de restrição para o amplicon de 'Vanda' (com BstN1) e 'Gizele' (sem BstN1). 


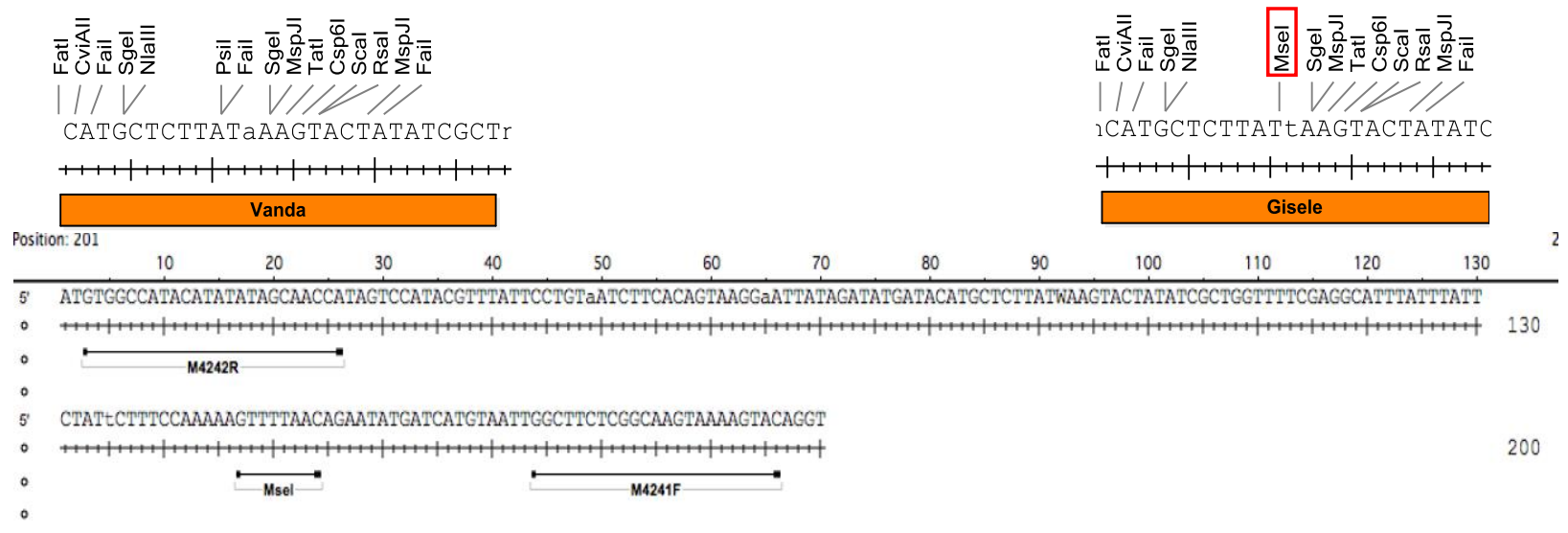

Figura 3-4. Desenho de um marcador CAPS (Cleaved Amplified Polymorphic Sequence) baseado na sequência obtida pela amplificação com o primer M4241. Abaixo a sequência obtida após amplificação da cultivar de alface (Lactuca sativa L.) 'Gizele' com o sítio de restrição da enzima Msel. Acima o segmento mostrando o mapa de restrição para o amplicom de 'Vanda' (sem Msel) e 'Gizele' (com Msel). 


\section{REFERÊNCIAS BIBLIOGRÁFICAS}

ALLEX, C.F. 1999. Computational methods for fast and accurate DNA fragment assembly. Ph.D. Thesis. University of Wisconsin.Wisconsin, Madison.

AGRAMA, H.A.; EIZENGA, G.C. \& YAN, W. 2007. Association mapping of yield and its components in rice cultivars. Molecular Breeding 19:341-356.

ALTSCHUL, S.F.; GISH, W.; MILLER, W.; MYERS, E.W. \& LIPMAN, D.J. 1990. Basic local alignment search tool. Journal of Molecular Biology 215:403-410.

ARUGA, D.; TSUCHIYA, N.; MATSUMURA, H.; MATSUMOTO, E. \& HAYASHIDA, N. 2012. Analysis of RAPD and AFLP markers linked to resistance to Fusarium oxysporum $\mathrm{f}$. sp. lactucae race 2 in lettuce (Lactuca sativa L.). Euphytica 187:1-9.

BOITEUX, L.S.; FONSECA, M.E.N. \& SIMON, P.W. 1999. Effects of plant tissue and DNA purification method on randomly amplified polymorphic DNA based genetic fingerprinting analyses in carrot. Journal of the American Society for Horticultural Science 124:32-38.

CABRAL, C.S.; SUINAGA, F.A.; REIS, A.; FONSECA, M.E.N. \& BOITEUX, L.S. 2015. Herança da resistência à murcha causada por Fusarium oxysporum f. sp. lactucae raça $1 \mathrm{em}$ um acesso de alface crespa. In: $8^{0}$ Congresso de Melhoramento de Plantas, Goiânia, CDROM.

CHRISTOPOULOU, M.; MCHALE, L.K.; KOZIK, A.; REYES-CHIN WO, S.; WROBLEWSKI, T. \& MICHELMORE, R.W. 2015a. Dissection of two complex clusters of resistance genes in lettuce (Lactuca sativa). Molecular Plant-Microbe Interactions 28:751-765

CHRISTOPOULOU, M.; REYES-CHIN WO, S.; KOZIK, A.; MCHALE, L.K.; TRUCO, M.J.; WROBLEWSKI, T.; \& MICHELMORE, R.W. 2015b. Genome-wide architecture of disease resistance genes in lettuce. G3: Genes| Genomes|Genetics 5:2655-2669.

COLLARD, B.C.Y. \& MACKILL, D.J. 2008. Marker-assisted selection: an approach for precision plant breeding in the twenty-first century. Philosophical Transactions of the Royal Society B: Biological Sciences 363:557-572.

ELLIS, P.; MCCLEMENT, S.; SAW, P.; PHELPS, K.; VICE, W.; KIFT, N.; ASTLEY, D. \& PINK, D. 2002. Identification of sources of resistance in lettuce to the lettuce root aphid, Pemphigus bursarius. Euphytica 125:305-315. 
FUKUDA M.; MATSUO, S.; KIKUCHI, K.; KAWAZU, Y.; FUJIYAMA, R. \& HONDA, I. 2011. Isolation and functional characterization of the FLOWERING LOCUS T homolog, the LsFT gene, in lettuce. Journal of Plant Physiology 168:1602-1607.

JEUKEN, M.; VAN WIJK, R.; PELEMAN, J. \& LINDHOUT, P. 2001. An integrated interspecific AFLP map of lettuce (Lactuca) based on two L. sativa $\times$ L. saligna $\mathrm{F}_{2}$ populations. Theoretical and Applied Genetics 103:638-647.

HAYES, R.; SIMKO, I.; MOU, B. \& MCCREIGHT, J.D. 2010. Lettuce breeding, USDA-ARS. California leafy greens research program, calgreens.org/control/uploads/200910_CLRBP_-_USDA_final_report.pdf.

HAYES, R.J.; TRENT, M.A.; MOU, B.; SIMKO, I.; GEBBEN, S.J. \& BULL, C.T. 2014. Baby leaf lettuce germplasm enhancement: developing diverse populations with resistance to bacterial leaf spot caused by Xanthomonas campestris pv. vitians. HortScience, 49:18-24.

HILL, M.; WITSENBOER, H.; ZABEAU, M.; VOS, P.; KESSELI, R. \& MICHELMORE, R.W. 1996. PCR-based fingerprinting using AFLPs as a tool for studying genetic relationships in Lactuca spp. Theoretical and Applied Genetics 93:1202-1210.

HU, J.; OCHOA, O.E.; TRUCO, M.J. \& VICK, B.A. 2005. Application of the TRAP technique to lettuce (Lactuca sativa L.) genotyping. Euphytica 144:225-235.

HULBERT, S. H. \& MICHELMORE, R.W. 1985. Linkage analysis of genes for resistance to downy mildew (Bremia lactucae) in lettuce (Lactuca sativa). Theoretical and Applied Genetics 70:520-528.

JEUKEN, M. \& LINDHOUT, P. 2002. Lactuca saligna, a non-host for lettuce downy mildew (Bremia lactucae), harbors a new race-specific Dm gene and three QTLs for resistance. Theoretical and Applied Genetics 105:384-391.

JOHNSON, W.C.; JACKSON, L.E.; OCHOA, O.; VAN WIJK, R.; PELEMAN, J., CLAIR, D. S. \& MICHELMORE, R.W. 2000. Lettuce, a shallow-rooted crop, and Lactuca serriola, its wild progenitor, differ at QTL determining root architecture and deep soil water exploitation. Theoretical and Applied Genetics 101:1066-1073.

KESSELI, R.V. \& MICHELMORE, R.W. 1986. Genetic variation and phylogenies detected from isozyme markers in species of Lactuca. Journal of Heredity 77:324-331.

KESSELI, R.; OCHOA, O. \& MICHELMORE, R.W. 1991. Variation at RFLP loci in Lactuca spp. and origin of cultivated lettuce ( $L$. sativa). Genome 34:430-436. 
KESSELI, R.V.; PARAN, I. \& MICHELMORE, R.W. 1994. Analysis of a detailed genetic linkage map of Lactuca sativa (lettuce) constructed from RFLP and RAPD markers. Genetics 136:1435-1446.

KUANG, H.; WOO, S.S.; MEYERS, B.C.; NEVO, E. \& MICHELMORE, R.W. 2004. Multiple genetic processes result in heterogeneous rates of evolution within the major cluster disease resistance genes in lettuce. Plant Cell 16:2870-2894.

KWON, S.; SIMKO, I.; HELLIER, B.; MOU, B. \& HU, J. 2013. Genome-wide association of 10 horticultural traits with expressed sequence tag-derived SNP markers in a collection of lettuce lines. The Crop Journal 1:25-33

LANDRY, B. S.; KESSELI, R. V.; FARRARA, B. \& MICHELMORE, R. W. 1987. A genetic map of lettuce (Lactuca sativa L.) with restriction fragment length polymorphism, isozyme, disease resistance and morphological markers. Genetics 116:331-337.

MAISONNEUVE, B.; BELLEC, Y.; ANDERSON, P. \& MICHELMORE, R.W. 1994 Rapid mapping of two genes for resistance to downy mildew from Lactuca serriola to existing clusters of resistance genes. Theoretical and Applied Genetics 89:96-104.

McHALE, L.K.; TRUCO, M.J.; KOZIK, A.; LAVELLE, DO.; OCHOA, O.E.; WROBLEWSKI, T.; KNAPP, S.J. \& MICHELMORE, R.W. 2009. The genomic architecture of disease resistance in lettuce. Theoretical and Applied Genetics 118:565-580.

MICHELMORE, R.W. 2010. Genetic variation in lettuce. California leafy greens research program,calgreens.org/control/uploads/Michelmore_Variation_report_20092010_final_(2)1.pdf

MEYERS, B.C.; CHIN, D.B.; SHEN, K.A.; SIVARAMAKRISHNAN, S.; LAVELLE, D.O.; ZHANG, Z. \& MICHELMORE, R.W. 1998. The major resistance gene cluster in lettuce is highly duplicated and spans several megabases. Plant Cell 10:1817-1832.

MEYERS, B.C.; KOZIK, A.; GRIEGO, A.; KUANG, H. \& MICHELMORE, R.W. 2003. Genome -wide analysis of NBS-LRR encoding genes in Arabidopsis. Plant Cell 15:809834.

MORENO-VÁZQUEZ, S.; OCHOA, O.E.; FABER, N.; CHAO, S.; JACOBS, J.M.E.; MAISONNEUVE, B.; KESSELI, R.V. \& MICHELMORE, R.W. 2003. SNP-based codominant markers for a recessive gene conferring resistance to corky root rot (Rhizomonas suberifaciens) in lettuce (Lactuca sativa). Genome 46:1059-1069.

NICAISE, V.; GERMAN-RETANA, S.; SANJUÁN, R.; DUBRANA, M.P.; MAZIER, M.; MAISONNEUVE, B.; CANDRESSE, T.; CARANTA, C. \& LEGALL, O. 2003. The 
eukaryotic translation initiation factor $4 \mathrm{E}$ controls lettuce susceptibility to the potyvirus Lettuce mosaic virus. Plant Physiology, 132:1272-1282.

PARAN, I. \& MICHELMORE, R.W. 1993. Development of reliable PCR based markers linked to downy mildew resistance genes in lettuce. Theoretical and Applied Genetics 85:985993.

PARRA, L.; MAISONNEUVE, B.; LEBEDA, A.; SCHUT, J.; CHRISTOPOULOU, M.; JEUKEN, M.; MCHALE, L.; TRUCO, M.J.; CRUTE, I. \& MICHELMORE, R. 2016. Rationalization of genes for resistance to Bremia lactucae in lettuce. Euphytica 1-18.

PELEMAN, J.D.; ROUPPE, VAN DER. VOORT, J.R. 2003. The challenges in marker assisted breeding. In: van Hintum THJL.; Lebeda, A.; Pink, D. \& Schut, J.W. (eds.). Eucarpia Leafy Vegetables. CGN. Noorwijkerhout. The Netherlands. p. 125-130.

PIN, P.A. \& NILSSON, O. 2012. The multifaceted roles of FLOWERING LOCUS T in plant development. Plant, Cell \& Environment 35:1742-1755.

RAUSCHER, G. \& SIMKO, I. 2013. Development of genomic SSR markers for fingerprinting lettuce (Lactuca sativa L.) cultivars and mapping genes. BMC Plant Biology 13: 1.

ROBBINS, M. A.; WITSENBOER, H.; MICHELMORE, R. W.; LALIBERTE, J. F. \& FORTIN, M. G. 1994. Genetic mapping of turnip mosaic virus resistance in Lactuca sativa. Theoretical and Applied Genetics 89: 583-589.

SANTOS, J.R.M. 1996. Methodology for screening tomato to Fusarium wilt, Verticillium wilt, gray leaf spot, early blight, and Septoria leaf spot. In: Proceedings of the International Symposium on Tropical Tomato Diseases. Recife PE, Brazil. pp. 164-166.

SHEN, K. A.; CHIN, D. B.; ARROYO-GARCIA, R.; OCHOA, O. E.; LAVELLE, D. O.; WROBLEWSKI, T.; MEYERS, B. C. \& MICHELMORE, R. W. 2002. Dm3 is one member of a large constitutively expressed family of nucleotide binding site leucine-rich repeat encoding genes. Molecular Plant-Microbe Interactions 15:251-261.

SIMKO, I.; JANSKY, S.; STEPHENSON, S. \& SPOONER, D. 2007. Genetics of resistance to pests and disease. In: Vreugdenhil, D.; Bradshaw, J.; Gebhardt, C.; Govers, F.; Taylor, M.; MacKerron, D. \& Ross, H. (eds.). Potato Biology and Biotechnology: Advances and Perspectives. Elsevier.Oxford. UK. p. 117-155.

SIMKO, I. 2009. Development of EST-SSR markers for the study of population structure in lettuce (Lactuca sativa L.). Journal of Heredity 100:256-262. 
SIMKO, I.; RAUSCHER, G.; SIDEMAN, R.G.; MCCREIGHT, J.D. \& HAYES, R.J. 2014. Evaluation and QTL mapping of resistance to powdery mildew in lettuce. Plant pathology 63:344-353.

SIMKO, I.; OCHOA, O. E.; PEL, M.A.; TSUCHIDA, C.; FONT I FORCADA, C.; HAYES, R.J. TRUCO, M.J.; ANTONISE, R.; GALEANO, C.H. \& MICHELMORE, R.W. 2015. Resistance to downy mildew in lettuce 'La Brillante'is conferred by dm50 gene and multiple QTL. Phytopathology 105:1220-1228.

STOFFEL, K.; VAN LEEUWEN, H.; KOZIK, A.; CALDWELL, D.; ASHRAFI, H.; CUI, X.; TAN, X.; HILL, T.; REYES-CHIN-WO, S.; TRUCO, M.J.; MICHELMORE, R.W. \& VAN DEYNZE, A. 2012. Development and application of a 6.5 million feature Affymetrix Genechip ${ }^{\circledR}$ for massively parallel discovery of single position polymorphisms in lettuce (Lactuca spp.). BMC Genomics 13:185.

SUZUKI, Y.; YASUI, T.; MATSUKURA, U. \& TERAO, J. 1996. Oxidative stability of bran lipids from rice variety [Oryza sativa (L)] lacking lipoxygenase-3 in seeds. Journal of Agricultural and Food Chemistry 44: 3479-3483.

SYED, N.H.; SØRENSEN, A.P.; ANTONISE, R.; VAN DE WIEL, C.; VAN DER LINDEN, C.G.; VAN'TWESTENDE, W.; HOOFTMAN, D.A.P.; NIJS D.E.N, H.C.M. \& FLAVELL, A. 2006. A detailed linkage map of lettuce based on SSAP, AFLP and NBS markers. Theoretical and Applied Genetics 112:517-527.

TRUCO, M.J.; ANTONISE, R.; LAVELLE, D.; OCHOA, O.; KOZIK, A.; WITSENBOER, H.; FORT, S.B.; JEUKEN, M.J.W.; KESSELI, R.V.; LINDHOUT, P.; MICHELMORE, R.W. \& PELEMAN, J. 2007. A high-density, integrated genetic linkage map of lettuce (Lactuca spp.). Theoretical and Applied Genetics 115:735-746.

TRUCO, M.J.; ASHRAFI, H.; KOZIK, A.; LEEUWEN, H.V.; BOWERS, J.; CHIN WO, SR.; STOFFEL, K.; XU, H.; HILL, T.; DEYNZE, A.V. \& MICHELMORE, R.W. 2013. An ultra-high-density, transcript-based, genetic map of lettuce. G3. Genes/Genome/Genetics 3:617-631.

TRUONG, H.T.; RAMOS, A.M.; YALCIN, F.; DE RUITER, M.; VAN DER POEL, H.J.A.; HUVENAARS, K.H.J.; HOGERS, R.C.J.; VAN ENCKEVORT, L.J.G.; JANSSEN, A.; VAN ORSOUW, N.J. \& VAN EIJK, M.J.T. 2012. Sequence-based genotyping for marker discovery and codominant scoring in germplasm and populations. Plos One 7:e37565.

UMATE, P. 2011. Genome-wide analysis of lipoxygenase gene family in Arabidopsis and rice. Plant Signaling \& Behavior 6:335-338.

VAN DER VOSSEN, E.A.G.; VAN DER VOORT, J.N.; KANYUKA, K.; BENDAHMANE, A.; SANDBRINK, H.; BAULCOMBE, D.C.; BAKKER, J.; STIEKEMA, W.J. \& KLEIN- 
LANKHORST, R.M. 2000. Homologues of a single resistance gene cluster in potato confer resistance to distinct pathogens: a virus and a nematode. The Plant Journal 23:567-576.

VAN DE WIEL, C.; ARENS, P. \& VOSMAN, B. 1999. Microsatellite retrieval in lettuce (Lactuca sativa L.). Genome 42:139-149.

WANG, Y.; LU, H. \& HU, J. 2016. Molecular mapping of high resistance to bacterial leaf spot in lettuce PI 358001-1. Phytopathology 106:1319-1325.

WAYCOTT, W.; FORT, S. B.; RYDER, E. J. \& MICHELMORE, R. W. 1999. Mapping morphological genes relative to molecular markers in lettuce (Lactuca sativa L.). Heredity 82: 245-251.

WITSENBOER, H.; KESSELI, R; FORTIN, M.; STANGHELLINI, M. \&. MICHELMORE, R.W. 1995. Sources and genetic structure of a cluster of genes for resistance to three pathogens in lettuce. Theoretical and Applied Genetics 91:178-188.

WROBLEWSKI, T.; CALDWELL, K.S.; PISKUREWICZ, U.; CAVANAUGH, K.A., XU, H.; KOZIK, A.; OCHOA, O.; MCHALE, L.K.; LAHRE, K.; JELENSKA, J.; CASTILLO, J.A.; BLUMENTHAL, D.; VINATZER, B.A.; GREENBERG, J.T. \& MICHELMORE, R.W. 2009. Comparative large-scale analysis of interactions between several crop species and the effector repertoires from multiple pathovars of Pseudomonas and Ralstonia. Plant Physiology 150:1733-1749.

ZHAO, K.; TUNG, C.; EIZENGA, G.; WRIGHT, M.; ALI, M.; PRICE, A.; NORTON, G.; ISLAM, M.; REYNOLDS, A.; MEZEY, J.; MCCLUNG, A.; BUSTAMANTE, C. \& MCCOUCH, S. 2011. Genome-wide association mapping reveals a rich genetic architecture of complex traits in Oryza sativa. Nature Communications 2: 467. 


\section{CAPÍTULO 4}

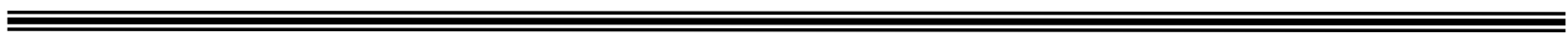

Emprego da estratégia de genotyping-by-sequencing (GBS) visando identificar regiões genômicas ligadas à resistência de Fusarium oxysporum f. sp. lactucae raça $1 \mathrm{em}$ alface 


\section{Emprego da estratégia de genotyping-by-sequencing (GBS) visando identificar regiões genômicas ligadas à resistência de Fusarium oxysporum f. sp. lactucae raça 1 em alface}

\section{RESUMO}

A alface (Lactuca sativa L.) é uma das principais hortaliças folhosas cultivadas no mundo. A produção de alface é severamente afetada pela murcha de fusário causada por Fusarium oxyporum f. sp. lactucae (FOLAC) raça 1. A cultivar 'Vanda' foi identificada como uma das mais estáveis fontes de resistência a isolados de FOLAC raça 1. No entanto, marcadores moleculares ligados à resistência em 'Vanda' ainda não estão disponíveis impedindo a determinação de sua localização cromossômica. A disponibilidade de marcadores ligados à resistência a murcha de fusário pode facilitar consideravelmente o melhoramento através da seleção assistida por marcadores (SAM). No presente estudo, a técnica de genotyping-bysequencing (GBS) foi utilizada na busca de polimorfismos de base única (SNPs) em uma população $\mathrm{F}_{2}(\mathrm{n}=82)$ desenvolvida a partir do cruzamento entre a cultivar 'Gizele' (suscetível) e 'Vanda' (resistente). Plantas $\mathrm{F}_{2}$ e $\mathrm{F}_{3}$ foram fenotipadas para resistência a FOLAC raça 1. Dois QTLs de efeito maior, explicando 30 a $40 \%$ da variação fenotípica observada na população $\mathrm{F}_{3} \mathrm{e}$ $\mathrm{F}_{2}$, respectivamente, foram localizados no cromossomo 9 em uma região que co-segrega com fatores de resistência descritos para murcha de verticílio e míldio. Um QTL de efeito menor (explicando $0.06 \%$ da variação fenotípica na população $\mathrm{F}_{3}$ ) foi identificado no cromossomo 4 em uma região que co-segrega com um dos genes de resistência ao míldio (Dm4). Este estudo estabelece que o principal locus de resistência presente na cultivar 'Vanda' está localizado na porção mediana do cromossomo 9. Marcadores em proximidade com esses QTLs são candidatos para o desenvolvimento de ferramentas de SAM em programas de melhoramento genético.

Palavras chave: Resistência, marcadores, QTLs, seleção assistida. 


\begin{abstract}
Lettuce (Lactuca sativa L.) is one of the most cultivated leafy vegetables around the world. In tropical and subtropical areas, the lettuce production has been severely affected by the Fusarium wilt disease caused by physiological races of Fusarium oxyporum f. sp. lactucae (FOLAC). The cultivar Vanda has been identified as one of the most stable sources of resistance to isolates of FOLAC race 1. However, molecular markers linked to resistance factors derived from this cultivar are not yet available, preventing the determination of its chromosomal location. The availability of markers linked to resistance to fusarium wilt can facilitate lettuce breeding via marker assisted selection (MAS). In the present study, the genotyping by sequencing (GBS) approach was used in a search for single base polymorphisms (SNPs) linked to FOLAC race 1 resistance using an $\mathrm{F}_{2}$ population $(\mathrm{n}=82)$ and $\mathrm{F}_{3}$ mapping populations from the cross between Gizele (susceptible) and Vanda (resistant). Plants were phenotyped for their reaction to FOLAC race 1 employing standard bioassays. Two major effect QTLs located on chromosome 9 could explain 30 and $40 \%$ of the phenotypic variation observed in $F_{3}$ and $F_{2}$ generations, respectively. This region on chromosome 9 encompasses previously reported resistance factors to verticillium wilt and downy mildew. One QTL with minor effect $(0.06 \%$ of the phenotypic variation in the population $\mathrm{F}_{3}$ ) was also identified on chromosome 4 , colocalizing with region encompasing the downy mildew resistance gene $\mathrm{Dm} 4$. This study establishes that a major resistance locus to FOLAC race 1 resistance in the cultivar 'Vanda' is more likely to be located in the central region of the chromosome 9. Markers in close proximity to these QTLs are candidates for the development of MAS tools for use in lettuce breeding programs.
\end{abstract}

Keywords: Resistance, QTL, marker assisted selection, breeding. 


\section{INTRODUÇÃO}

A alface (Lactuca sativa L.) é comercialmente produzida no Brasil e em muitos países ao redor do mundo, fazendo com que a cultura seja a mais popular do grupo de plantas folhosas. A alface é uma espécie de autopolinização pertencente à família Asteraceae, é diploide ( $2 n=2 x=18)$ e apresenta um genoma de grande tamanho $(2.7 \mathrm{~Gb})$, um dos maiores genomas caracterizados entre as espécies de plantas cultivadas (Arumuganathan \& Earle, 1991; The Lettuce Genome Sequencing Consortium, http: //gr.genomecenter.ucdavis.edu).

A murcha de fusário, causada pelo patógeno Fusarium oxyporum f. sp. lactucae (FOLAC), é uma das doenças mais importantes da cultura de alface, acarretando perdas de produção em diferentes regiões do mundo (Scott $\boldsymbol{e t}$ al., 2012). Esse patógeno de solo coloniza as raízes e invade o sistema vascular, causando amarelecimento, murcha e posterior morte da planta. A disseminação ocorre pelo vento, chuva e fatores ambientais por meio da movimentação do solo infestado ou sementes.

As quatro raças fisiológicas de FOLAC atualmente caracterizadas $(1,2,3$ \& 4) são definidas com base na reação em cultivares diferenciais de alface (Fujinaga et al., 2003). A raça 1 é a que apresenta a mais ampla distribuição geográfica, sendo detectada na Itália, Japão, Portugal, Taiwan, Irã, Estados Unidos e Brasil (Pasquali et al., 2003, 2007; Ventura \& Costa, 2008; Cabral, 2012). O Japão é o único país onde a presença de três raças distintas $(1,2 \& 3)$ foi relatada (Fujinaga et al., 2001, 2003; Yamauchi et al., 2004). Mais recentemente, uma nova raça (= raça 4) foi caracterizada, estando restrita apenas a Holanda (Gilardi et al., 2016).

O emprego de cultivares resistentes oferece a melhor solução para o controle da murcha de fusário. Fontes de resistência estáveis e duráveis foram identificadas e podem ser usadas em programas de melhoramento genético (Cabral et al., 2013). Entretanto, os processos clássicos de 
avaliação e caracterização de novos genótipos para resistência demanda muito tempo, espaço físico e infraestrutura de laboratório e telados. Assim, a disponibilidade de marcadores moleculares em estreita ligação com loci de resistência é de grande importância para aumentar a escala e eficiência do melhoramento da alface.

Nos últimos anos, o uso de marcadores moleculares tem acelerado o melhoramento de plantas em uma série de características, incluindo resistência a doenças e insetos (Tester $\boldsymbol{e t}$ al., 2010). A disponibilidade de mapas genéticos densos tem facilitado a seleção assistida por marcadores, clonagem posicional de genes de resistência e mapeamento de loci de características quantitativas (QTLs) de interesse agronômico em muitas culturas (Collard et al., 2005; McPhee et al., 2012).

Em alface, a resistência genética à murcha de fusário causada por isolados de FOLAC raça 2 foi caracterizada como sendo controlada por um gene dominante (locus RRD2) (Aruga et al., 2012). No entanto, em relação ao FOLAC raça 1 , observou-se que a resposta de resistência é controlada por múltiplos fatores genéticos, dependendo da fonte de resistência empregada. Estudos realizados nos Estados Unidos mostraram uma herança quantitativa com a presença de diversos QTLs em diferentes regiões genômicas (Michelmore et al., 2010; Truco et al., comunicação pessoal). Todavia, estudos mais recentes, com a cultivar de alface crespa 'Vanda', indicaram um controle da resistência mediado por um locus monogênico, dominante e com penetrância elevada (Cabral et al., 2015, Ver capítulo 2).

Várias ferramentas genômicas e recursos genéticos estão hoje disponíveis para o melhoramento da alface, permitindo uma análise mais detalhada de genes de interesse. Muitas características agronômicas foram posicionadas em um mapa genético integrado (Truco et al., 2013), o que facilita uma análise global de genes resistência a doenças em alface. A maioria dos genes candidatos de resistência (Resistance Gene Candidates - RGCs) identificados apresenta 
motivos ou domínios ricos em códons codificadores do aminoácido leucina (LRR) que podem estar isolados ou em combinação com sítios de ligação a nucleotídeos (NBS-LRR) ou ainda em combinação com motivos de transmembrana (TM-LRR) (Hammond-Kosack \& Jones, 1997). Os domínios NBS-LRR podem apresentar organizações estrutrais ainda mais complexas tais como TIR (Toll interleucine receptor)-NBS-LRR (sigla TNL) ou não TNL/coiled-coil-NBS-LRR (sigla CNL). Da mesma forma, o grupo TM-LRRs pode ser dividido em duas classes: receptores do tipo quinase (Receptor-like kinases - RLKs) ou proteínas do tipo receptoras (RLPs) (Sekhwal et al., 2015).

Após uma descrição detalhada da arquitetura genômica da alface feita por McHale et al., 2009 e Christopoulou et al. (2015a,b), o atual mapa de referência contém 36 loci associados com fenótipos de resistência e 20 QTLs para 10 agentes patogênicos e uma para insetos. Trinta e quatro dos 36 fenótipos de resistência co-segregam com genes relacionados à defesa (McHale $\boldsymbol{e t}$ al., 2009). Além disso, uma versão preliminar (draft) englobando $2.4 \mathrm{~Gb}$ do genoma de referência de L. sativa cv. 'Salinas' está agora disponível, juntamente com um mapa genético ultradenso contendo 1.460 genes candidatos organizados em supercontigs (= scaffolds) ordenados ao longo dos nove grupos de ligação (http://lgr.genomecenter.ucdavis.edu; R. W. Michelmore et $\boldsymbol{a l}$., comunicação pessoal). Estudos sobre a diversidade genética de cultivares de alface indicam níveis elevados de polimorfismos, especialmente para cinco dos principai clusters de resistência (MRCs - Major Resistance Clusters) localizados nos cromossomos 1, 2, 3, 4, \& 8 (McHale et al., 2009; Truco et al., 2013; Christopoulou et al., 2015a,b).

Muitos estudos têm empregado marcadores moleculares para aumentar a precisão na descriminação de acessos dentro coleções de germoplasma (Wouw et al., 2011). No entanto, o elevado custo das análises conduzidas em grande escala tem restringido a aplicação prática em programas de melhoramento de plantas. Novos desenvolvimentos nos métodos de genotipagem 
baseados em Next Generation Sequencing (NGS) têm possibilitado enormes avanços na caracterização de genomas vegetais de forma viável e de baixo custo (Deschamps $\boldsymbol{e t}$ al., 2012; Bhatia et al., 2013). O método de genotyping-by-sequencing (GBS), desenvolvido pela empresa Illumina, visa reduzir a complexidade nos processos de análise genômica (Elshire $\boldsymbol{e t}$ al., 2001; Deschamps et al., 2012; Bhatia et al., 2013). O GBS é um método relativamente simples é rápido para gerar dados de SNPs quando comparado com os outros métodos de redução da complexidade de genoma, tais como Reduced Representation Libraries (RRL) e Restriction Site Association DNA Sequencing (RAD) (Deschamps et al., 2012; Bhatia et al., 2013).

A estratégia GBS tem uma ampla variedade de aplicações em uma gama de estudos genéticos incluindo, diversidade genômica, análises filogenéticas, desenvolvimento de marcadores moleculares em larga escala e identificação de regiões genômicas contendo genes candidatos e características quantitativas de interesse (QTLs). Em alface, esse conjunto de informações foi convertido em marcadores de interesse para sistemas aplicados de seleção de plantas superiores, combinando múltiplas características de interesse (Truco et al., 2013). Visando dar suporte aos programas de melhoramento de alface, o presente trabalho tem como objetivo identificar quais regiões do genoma de alface estão ligadas ao fator(es) de resistência a FOLAC raça 1 utilizando a estratégia GBS.

\section{OBJETIVOS}

\subsection{Objetivo Geral}

-Uso da estratégia de genotyping-by-sequencing (GBS) para identificar marcadores moleculares em uma população de mapeamento derivada do cruzamento entre 'Gizele' (suscetível) e 'Vanda' (resistente) visando definir as regiões genômicas ligadas à resistência à raça 1 de Fusarium oxysporum f. sp. lactucae. 


\subsection{Objetivos Específicos}

- Identificar regiões genômicas que controlam a resistência a FOLAC raça 1.

- Definir a posição cromossômica dos loci de resistência no mapa genético da alface.

- Ampliar as ferramentas moleculares disponíveis para a identificação de genes de resistência associados com os mecanismos genéticos que regulam essa interação planta patógeno.

\section{MATERIAL \& MÉTODOS}

3.1. Parentais utilizados para a produção de populações segregantes - Foram utilizadas como parentais para geração das populações de mapeamento genético as cultivares do segmento crespa, sendo 'Vanda (Empresa Sakata Seed Sudamerica') o parental resistente a FOLAC raça 1 e 'Gizele' (comercializada no Brasil pela Empresa Topseed) como o parental suscetível a essa raça.

\subsection{Caracterização fenotípica das linhagens parentais e populações segregantes -} Oitenta e dois (82) indivíduos da população $\mathrm{F}_{2}$ do cruzamento entre 'Gizele' $x$ 'Vanda' foram utilizados nas análises de ligação. Para confirmar os genótipos dos indivíduos da $\mathrm{F}_{2}, 9$ a 16 plantas da população $\mathrm{F}_{3}$ foram avaliadas. Essas duas populações foram utilizadas para fenotipagem da resistência a doença. O teste de resistência a FOLAC raça 1 foi realizado como descrito por Cabral et al. (2013). A severidade da doença foi avaliada 20 dias após a inoculação de acordo com a escala de notas adaptada de Santos (1996), sendo 1= plantas sem sintomas; 2 = plantas sem sintomas de murcha ou amarelecimento, mas com escurecimento vascular; $3=$ plantas com escurecimento vascular intenso e com início de murcha ou amarelecimento foliar; 4 $=$ plantas com murcha intensa, associada com amarelecimento e necrose foliar; $5=$ plantas 
mortas. Com base nas notas recebidas, as plantas foram arbitrariamente classificadas como resistentes $(\mathrm{R} \leq 2)$ ou suscetíveis $(\mathrm{S}>2)$. Para o mapeamento de $\mathrm{QTL}$, utilizaram-se as notas de severidade das populações $F_{2}$ e $F_{3}$ (designadas como [F2_RS_(1) e F2_RS_(2)], [F3_RS_(1) e F3_RS_(2)], com notas: 1 e/ou 2 para plantas resistente e 5 para suscetíveis. Na população $F_{3}$ empregou-se as médias da avaliação de 9 a 16 plantas.

\subsection{Extração de DNA de genômico de linhagens parentais e indivíduos das populações}

segregantes - As amostras foliares foram coletadas dez dias após a inoculação e mantidas em casa de vegetação. O DNA foi extraído individualmente de cada planta das linhagens parentais e de indivíduos das populações segregantes de acordo com a metodologia de CTAB $2 \mathrm{X}$ com a incorporação de algumas modificações (Boiteux $\boldsymbol{e t}$ al., 1999). Para confirmação da qualidade das amostras de DNA, alíquotas foram utilizadas em uma reação de PCR em condições previamente testadas. O resultado negativo da amplificação indicou a presença de inibidores da reação na maioria das amostras. Desta forma os DNAs foram re-purificados usando o kit Power Clean ${ }^{\circledR}$ Pro DNA Clean-up, seguindo os padrões recomendados pelo fabricante do kit (MO BIO Laboratories- Carlsbad, CA, USA). Após este procedimento a reação de PCR foi repetida, desta vez com sucesso, indicando que os inibidores de PCR foram retirados.

3.4. Preparação das bibliotecas e sequenciamento - O DNA de 82 indivíduos da população $\mathrm{F}_{2}$ e dos dois parentais foram quantificados, normalizados, cortados com a enzima de restrição e ligados adaptadores com código de barras, seguindo o protocolo desenvolvido por Poland et al. (2012). As bibliotecas foram feitas da seguinte forma: Em uma placa de 96 poços foram adicionados $5 \mu \mathrm{L}$ de adaptadores (Elshire $\boldsymbol{e t}$ al, 2011) em cada poço. Em seguida utilizouse o concentrador SpeedVac por 30 minutos para secar todo o conteúdo. Em seguida acrescentouse 50 ng a 100 ng do DNA da alface e foi feita a concentração da placa da mesma forma anterior. Posteriormente foi realizada a digestão da seguinte maneira: $\mathrm{O}$ mix da reação constitui de $0,2 \mu \mathrm{L}$ 
da enzima AvaII, $4 \mu \mathrm{L}$ de tampão (CutSmart ${ }^{\circledR}$ Buffer_NEB), 35,8 $\mu \mathrm{L}$ de $\mathrm{H}_{2} \mathrm{O}$ MilliQ, no total da reação de $40 \mu \mathrm{L}$. O tempo utilizado pela enzima foi de uma hora a temperatura constante de $37^{\circ} \mathrm{C}$. Em seguida foi feita a ligação dos adaptadores as extremidades do inserto. A reação apresentou a seguinte composição: $5 \mu \mathrm{L}$ de buffer ligase, $1 \mu \mathrm{L}$ de T4 DNA ligase (New England Biolabs, NEB) e $4 \mu \mathrm{L}$ de $\mathrm{H}_{2} \mathrm{O}$ MiliQ, adicionando $10 \mu \mathrm{L}$ em cada poço. A sequência de adaptadores contendo o barcode específico para cada amostra e o sítio de restrição comum para AvaII foi o recomendado pela Illumina e utilizado como rotina Centro de Genomica de UC Davis (Figura 4-1).

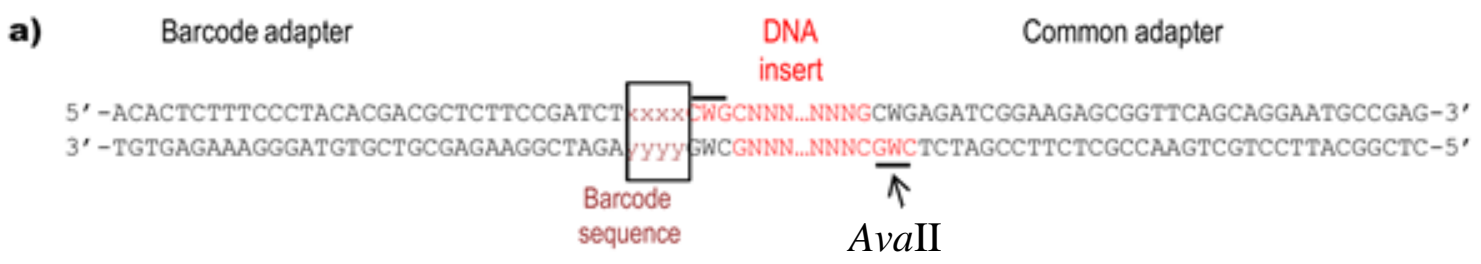

Figura 4-1. Sequência de adaptadores contendo o barcode específico para cada amostra e o sítio de restrição para AvaII.

As amostras foram incubadas a $22^{\circ} \mathrm{C}$ por uma hora e aqueceu-se a $65^{\circ} \mathrm{C}$ por 20 minutos para inativar a T4 DNA ligase. Após essa etapa retirou-se $5 \mu \mathrm{L}$ de cada poço e adicionou-se $2.500 \mu \mathrm{L}$ do $\mathrm{CP}$ buffer Omega Bio-Tek Cycle Pure Kit ${ }^{\circledR}$. Uma alíquota de $500 \mu \mathrm{L}$ de cada amostra foram colocados em uma membrana de sílica que foi posteriormente centrifugada a 1400 rpm por 1 minuto. Esse procedimento foi repetido por cinco vezes. Depois colocou-se $50 \mu \mathrm{L}$ do ellution buffer na membrana de sílica, incubou-se por 10 minutos e centrifugou-se a $1400 \mathrm{rpm}$ por 1 minuto. Desses $50 \mu \mathrm{L}$ de reação de ligação dos adaptadores, $12 \mu \mathrm{L}$ foram utilizados na PCR (passo posterior). Foram adicionados aos $12 \mu \mathrm{L}$ de DNA mais adaptadores, volumes de 25 $\mu \mathrm{L}$ do Taq Master Mix (NEB), $2 \mu \mathrm{L}$ do par de primers (12,5 $\mu \mathrm{M}$ de cada primer): (A) 5'-AAT- 
GAT-ACG-GCG-ACC-ACC-GAG-ATC-TAC-ACT-CTT-TCC-CTA-CAC-GAC-GC-TC-TTCCGA-TCT-3' (B) 5'-CAA-GCA-GAA-GAC-GGC-ATA-CGA-GAT-CGG-TCT-CGG-CATTCC-TGC-TGA-ACC-GCT-CTT-CCG-ATCT-3' e $11 \mu \mathrm{L}$ de $\mathrm{H}_{2} \mathrm{O}$ Milli-Q. O ciclo de amplificação consistiu de $72^{\circ} \mathrm{C}$ durante 5 minutos, $98^{\circ} \mathrm{C}$ por 30 segundos, seguido de 18 ciclos de 10 segundos para $98^{\circ} \mathrm{C}, 65^{\circ} \mathrm{C}$ por 30 segundos, para $72^{\circ} \mathrm{C}$ por 30 segundos com a etapa final de extensão de $72^{\circ} \mathrm{C}$ por 5 minutos. Em seguida, o produto da PCR foi purificado com o Bio-Tek Cycle Pure kit (Omega). Para tal adicionou-se $250 \mu \mathrm{L}$ de CP Buffer para $50 \mu \mathrm{L}$ de DNA. Os tubos foram suavemente agitados e previamente centrifugados. Posteriormente adicionou-se as amostras na coluna HiBind ${ }^{\circledR}$ DNA e foi realizada a purificação como se segue: Foi feita a centrifugação a $14000 \mathrm{rpm}$ por 1 minuto. Descartou-se o filtrado e o tubo foi re-utilizado. Adicionou-se $700 \mu \mathrm{L}$ de DNA Wash Buffer, centrifugou-se novamente a $14000 \mathrm{rpm}$ por 1 minuto e descartou-se o filtrado. Adicionou-se $700 \mu \mathrm{L}$ de DNA Wash Buffer, centrifugou-se a $14000 \mathrm{rpm}$ por 1 minuto e descartou-se o filtrado. A mini coluna HiBind ${ }^{\circledR}$ DNA vazia foi centrifugada a $14000 \mathrm{rpm}$ por 2 minutos para secar. Transferiu-se a mini coluna HiBind ${ }^{\circledR}$ DNA para um tubo de $1.5 \mathrm{~mL}$ e adicionou-se $30 \mu \mathrm{L}$ de Ellution Buffer por 10 minutos. A qualidade e a quantidade das bibliotecas foram mensuradas utilizando os aparelhos Quibit High Sensitivity dsDNA kit (Invitrogen, USA) e o Bionalyzer DNA 1000 Chip (Agilent, USA). O total de DNA utilizado foi entre $100 \mathrm{pg} / \mu \mathrm{L}$ a $10 \mathrm{ng} / \mu \mathrm{L}$. Em seguida, a biblioteca foi enviada para o Centro de Genômica da UC Davis (UC Davis Genome Center, Davis, Califórnia, EUA) para o sequenciamento (NGS) com Illumina Hi-seq 3000, utilizando quatro linhas do sequenciador e com isso permitindo a corrida de várias amostras em uma mesma linha. Uma segunda biblioteca de GBS foi constituída para incluir amostras que não tiveram bons resultados na primeira biblioteca (baixo número de reads). Polimorfismos (SNPs) associados com os fenótipos contrastantes foram identificados via análise genômica comparativa usando a plataforma de 
bioinformática da UC Davis. O processamento eficiente desses dados das sequências de GBS foi feito via um pipeline de bioinformática, denominada TasseL-GBS software (Bradbury et al., 2007; Glaubitz et al., 2014).

3.5. Processamento das sequências e identificação dos SNPs - O processamento (pipeline) presente no software TASSEL (Trait Analysis by Association, Evolution and Linkage) versão 3.0 (http://www.maizegenetics.net/tassel) foi desenvolvido para processar os dados de sequência do Illumina Hiseq 300 (Glaubitz et al., 2014). As etapas envolvendo esta pipeline foram executadas em scripts separados, utilizando diferentes ferramentas de software disponíveis publicamente (FASTQ, BWA, TBT e TOPM). Os SNPs foram filtrados utilizando TOPMtools baseado nos seguintes critérios: proportion of taxa covered by TagLocus, Minimum minor allelle frequency (mnMAF) e inbreeding coefficient $(\mathrm{mnF})$ e missing data. Para determinar o número de cópias e coordenadas genômicas, as tags sequências de cada indivíduo foram alinhadas com o genoma de referência de L. sativa cv. 'Salinas' (http: //lgr.genome center.uc davis.edu; R. W. Michelmore, comunicação pessoal). Os indivíduos foram classificados como " $\mathrm{A}$ " quando homozigotos para o alelo parental feminino, "B" quando homozigotos para o alelo parental masculino e "H" quando heterozigotos.

3.6. Mapeamento de QTLs - Os dados de ligação foram obtidos utilizando o programa JoinMap 4.0 (Van Ooijen, 2006). O mapeamento foi realizado com seguintes limites: frequência de recombinação $<0,4 \mathrm{LOD}>1$. As frequências de recombinação foram convertidas para mapear distâncias em centimorgans (cM) usando a função Kosambi (Kosambi, 1944). A análise de QTL foi realizada usando o programa Win QTL Cartographer v. 2.5 (Wang et al., 2005). Os QTLs foram identificados utilizando Composite Interval Mapping (CIM) (Jansen \& Stam, 1994). Os limites de significância estatística (LOD, thresholds log likelihood ratio) foram gerados para cada um dos caracteres utilizando análise de permutação baseada em 1000 permutações e 0,05 de 
significância (Doerge \& Churchill, 1996). Também foi calculado o percentual de variação fenotípica atribuída a cada QTL $\left(\mathrm{R}^{2}\right)$. Em seguida, os grupos de ligação foram desenhados com MapChart 2.2 (Voorrips, 2002), mostrando as posições dos QTLs no mapa genético.

\section{RESULTADOS}

\subsection{Genotipagem de marcadores moleculares e mapeamento de QTLs - A} genotipagem dos marcadores moleculares e a construção do mapa genético foi realizada utilizando 82 plantas $\mathrm{F}_{2}$ do cruzamento entre 'Gizele' $x$ 'Vanda'. Cada indivíduo genotipado usando o Illumina Hiseq 3000 produziu aproximadamente 4,5 milhões reads por amostra. Dez mil e dezessete (10.017) SNPs polimórficos foram identificados entre os parentais e validados na população segregante. Posteriormente, os dados genotípicos foram condensados em 1484 scaffolds ou supercontigs. Após filtragem baseado em missing data $(<20 \%)$, teste do quiquadrado (3:1 p>0,05) e número de SNPs por scaffold. Quatrocentos e dezessete (417) scaffolds (Figura4-2, 4-3) contendo polimorfismos foram selecionados para a construção do mapa de ligação.

4.2. Mapeamento do QTL - O mapa consistiu de 17 grupos de ligação, com um comprimento total de 1.133 cM. Os grupos de ligação 3, 4, 5, 7, 8 e 9 consistem de subgrupos LG 3a, LG 3b, LG 4a, LG 4b, LG 5a, LG 5b, LG 7a, LG 7b, LG 8a, LG 8b, LG 9a e LG 9b, respectivamente e o grupo de ligação 1 por 3 subgrupos (LG1a, LG1b e LG1c) (Tabela 4-1). A análise de QTL para resistência a FOLAC raça 1 foi realizado no mapa de ligação construído com os conjuntos de dados de severidade da doença. Somente o LOD scores nos cromossomos 4 e 9 mostraram picos que ultrapassaram o limite dos limiares (thresholds) estabelecidos (Figura 4-4), conforme calculado por Win QTL Cartographer v 2.5. 
O QTL localizado no cromossomo 4a está entre os scaffolds: [Lsat_1_v5_g4_2792], [Lsat_1_v5_g4_673426], [Lsat_1_v5_g4_3422], [Lsat_1_v5_g4_1153], [Lsat_1_v5_g4_5355], [Lsat_1_v5_g4_1736], [Lsat_1_v5_g4_1100] e [Lsat_1_v5_g4_ Lsat_1_v5_g4_1990]. Esses scaffolds que cobrem este QTL contêm genes membros da família RGC12, classificados no grupo dos TNLs. Na população [F3_RS_(1), F3_RS_(2)], o LOD score e a percentagem de variação fenotípica $\left(\mathrm{R}^{2}\right)$ explicada pelo QTL foi de (LOD>5 e $\mathrm{R}^{2}=0,06 \%$, respectivamente) (Figuras 4-5, 4-7; Tabela 4-2).

Dois QTLs foram detectados no cromossomo 9 com localização no scaffold [Lsat_1_v5_g9_108] (Figuras 4-6, 4-7). Esse scaffold contêm genes pertencentes à família RGC12. Outro QTL foi posicionado nos scaffolds [Lsat_1_v5_g9_111 e Lsat_1_v5_g9_448] (Figuras 4-6, 4-7). O LOD score e a percentagem de variação fenotípica $\left(\mathrm{R}^{2}\right)$ na população [F2_RS_(1) e F2_RS_(2)], foram: LOD > 5 e $\mathrm{R}^{2}=40 \%$. Para a população [F3_RS_(1) e F3_RS_(2)], foram: LOD > 4 e $\mathrm{R}^{2}=30 \%$ (Tabela 4-2). 
Tabela 4-1. Mapa genético da população $F_{2}$ do cruzamento entre os genitores de alface contrastantes 'Gizele' (suscetível) $x$ 'Vanda' (resistente) para resistência a Fusarium oxysporum f. sp. lactucae (FOLAC) raça 1.

\begin{tabular}{ccc}
\hline \multicolumn{3}{c}{ Mapa genético } \\
\hline Grupo de ligação & $\begin{array}{c}\text { Número de } \\
\text { marcadores }\end{array}$ & $\begin{array}{c}\text { Comprimento } \\
\text { (cM) }\end{array}$ \\
\hline \hline $1-(1 \mathrm{a})$ & 4 & 13,093 \\
$2-(1 \mathrm{~b})$ & 8 & 14,618 \\
$3-(1 \mathrm{c})$ & 10 & 36,498 \\
$4-(2)$ & 16 & 52,347 \\
5-(3a) & 10 & 40,975 \\
6-(3b) & 10 & 24,744 \\
$7-(4 a)$ & 36 & 96,645 \\
$8-(4 b)$ & 56 & 98,258 \\
$9-(5 a)$ & 33 & 87,883 \\
$10-(5 b)$ & 16 & 54,574 \\
$11-(6)$ & 42 & 150,128 \\
$12-(7 a)$ & 5 & 22,128 \\
$13-(7 b)$ & 51 & 134,43 \\
$14-(8 a)$ & 25 & 49,603 \\
$15-(8 b)$ & 57 & 150,484 \\
$16-(9 a)$ & 27 & 79,99 \\
$17-(9 b)$ & 11 & 26,586 \\
\hline Total & 417 & $1.132,984$ \\
\hline \hline
\end{tabular}


Tabela 4-2. QTLs para resistência a Fusarium oxysporum f. sp. lactucae (FOLAC) raça 1 (com suas designações de acordo com as notas de severidade identificados em populações $F_{2}$ e $F_{3}$ derivadas do cruzamento entre genitores de alface contrastantes 'Gizele' (suscetível) $x$ 'Vanda' (resistente).

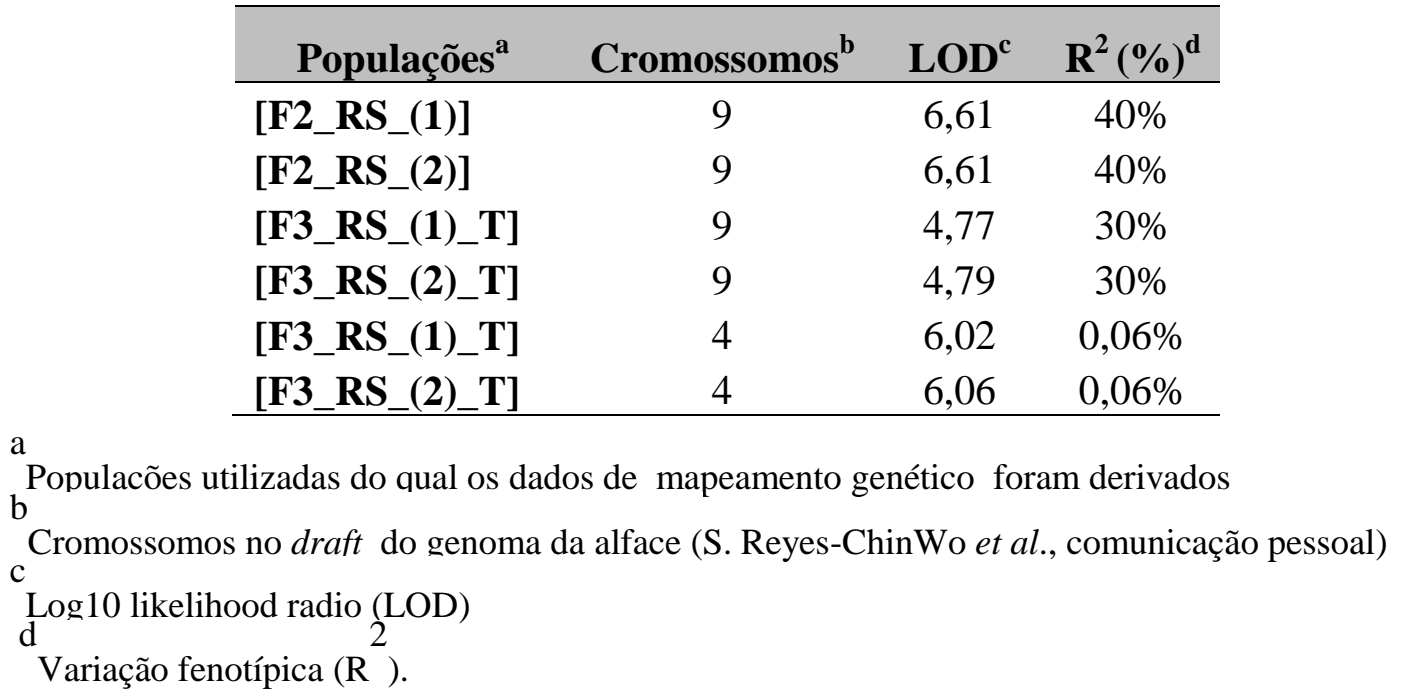




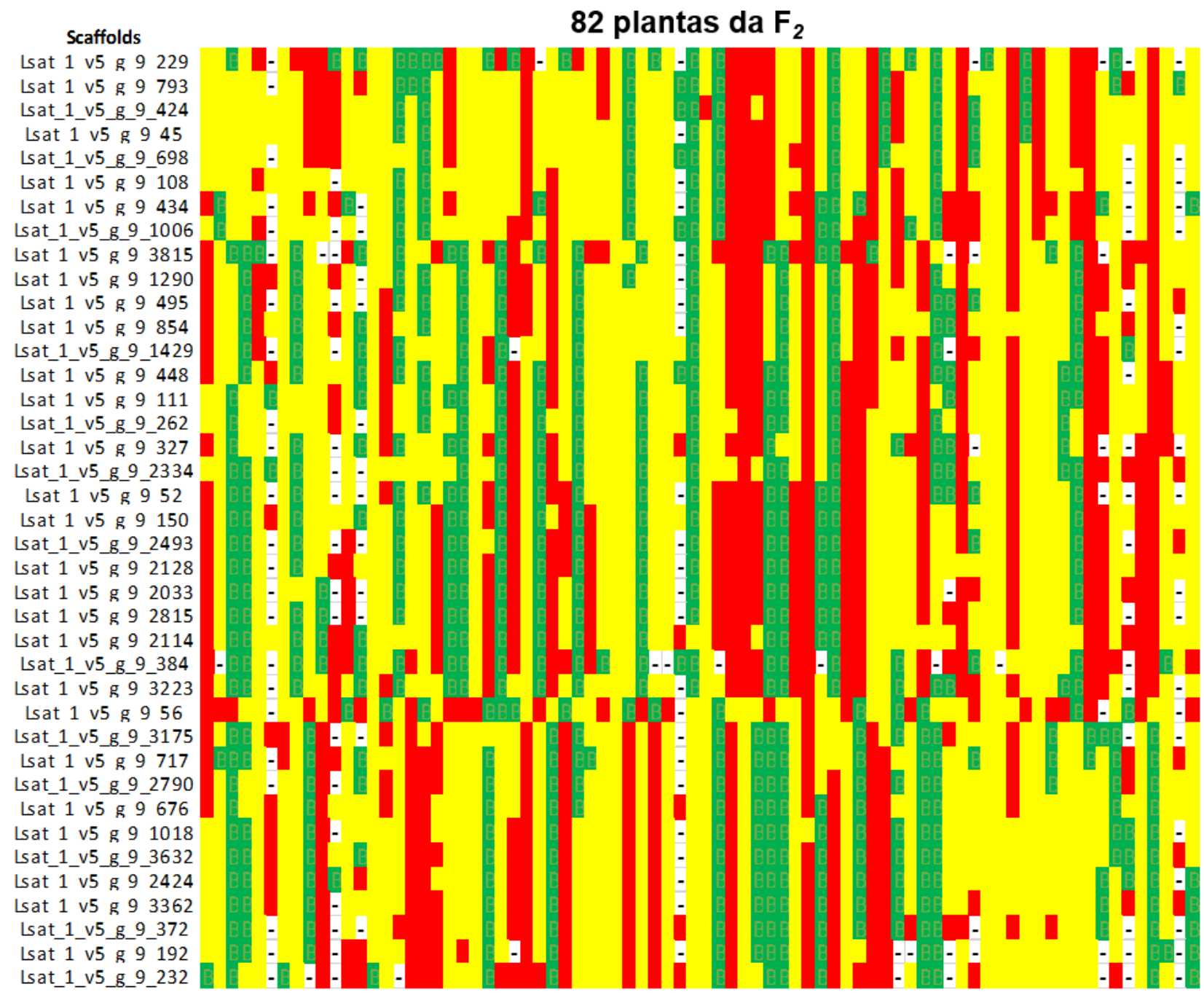

\section{Genótipos}

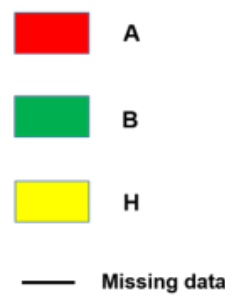

Figura 4-2. Molde do mapa genético de alface no cromossomo 9 . As 82 plantas $F_{2}$ foram obtidas do cruzamento entre genitores de alface contrastantes 'Gizele' (suscetível) $x$ 'Vanda' (resistente) para resistência a Fusarium oxysporum f. sp. lactucae raça 1. As linhas correspondem as distintas localizações cromossômicas e as colunas da correspondem os genótipos da população $\mathrm{F}_{2} \mathrm{em}$ cada local. O genótipo "A" corresponde ao parental feminino ('Gizele'), "B" para o parental masculino ("Vanda'), " $\mathrm{H}$ " para heterozigoto, e "." para os missing data. Um total de 38 scaffolds foram posicionados nesse cromossomo. 


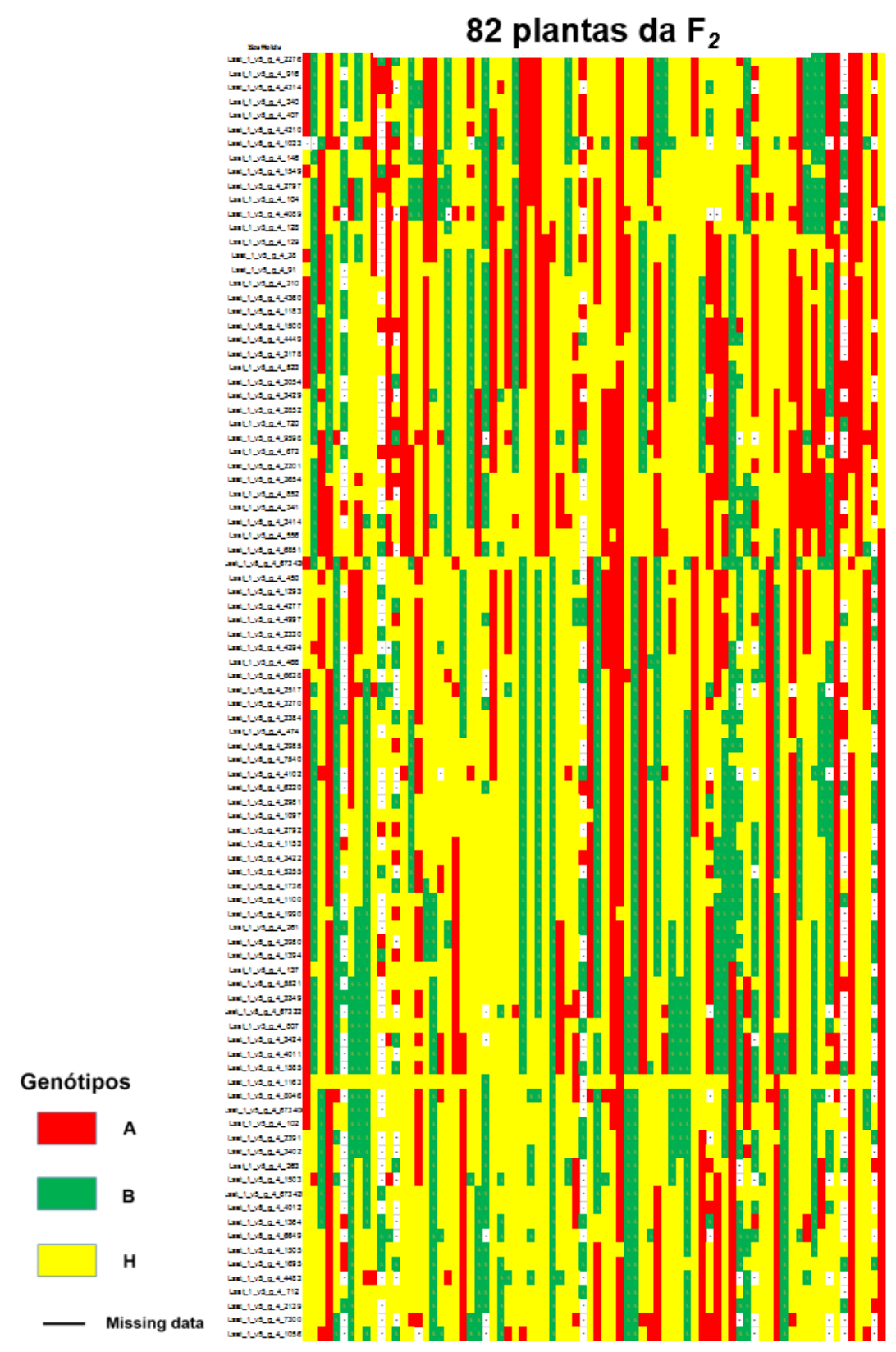

Figura 4-3. Molde do mapa genético de alface no cromossomo 4. As 82 plantas $\mathrm{F}_{2}$ foram obtidas do cruzamento entre genitores de alface contrastantes 'Gizele' (suscetível) $x$ 'Vanda' (resistente) para resistência a Fusarium oxysporum f. sp. lactucae raça 1. As linhas correspondem as distintas localizações cromossômicas e as colunas da correspondem os genótipos da população $\mathrm{F}_{2} \mathrm{em}$ cada local. O genótipo "A" corresponde ao parental feminino ('Gizele'), "B" para o parental masculino ("Vanda'), "H" para heterozigoto e ".'" para os missing data. Um total de 92 scaffolds foram posicionados nesse cromossomo. 


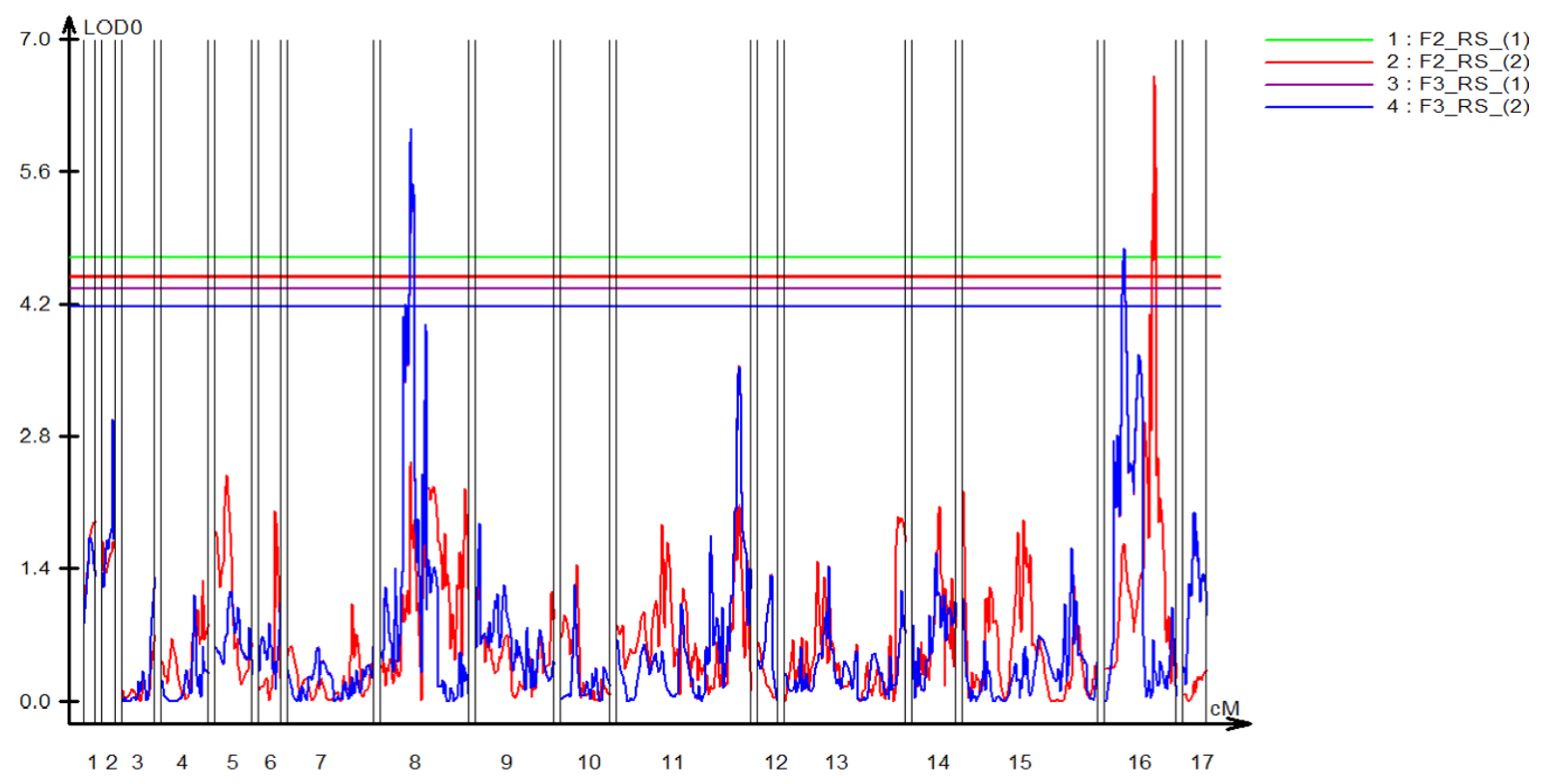

Figura 4-4. QTLs ligados a resistência à murcha de fusário da alface causada por Fusarium oxysporum f. sp. lactucae raça 1 posicionados nos grupos de ligação 8 (4a) e 16 (9a). As linhas verticais azul, roxa, vermelha e verde indicam o limite de significância estatística (LOD) de acordo com a população empregada $\left(\mathrm{F}_{2}\right.$ e $\left.\mathrm{F}_{3}\right)$ e as notas de severidade. 


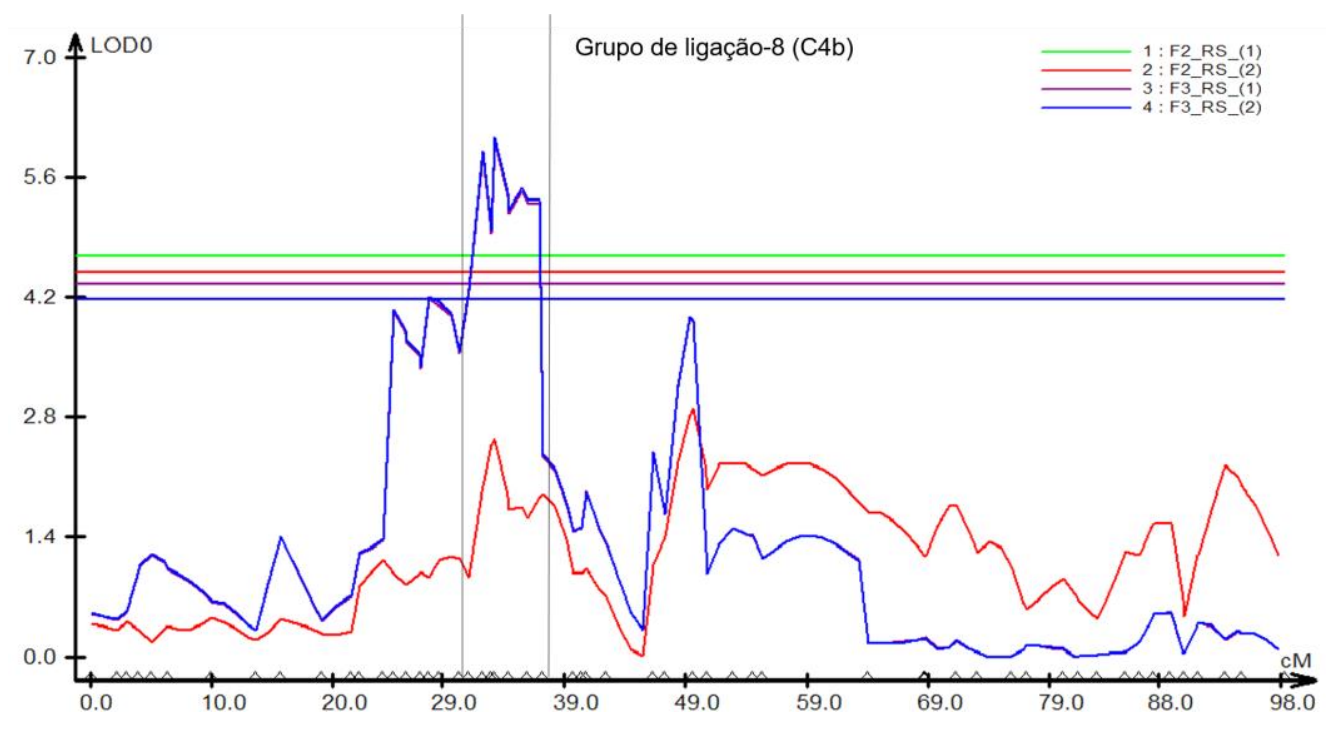

Figura 4-5. QTL ligado a resistência à murcha de fusário da alface causada por Fusarium oxysporum f. sp. lactucae raça 1 posicionado entre os marcadores [Lsat_1_v5_g4_2792 a Lsat_1_v5_g4_1990] no grupo de ligação 8 (Cromossomo 4a). (LOD = 6,02). As linhas verticais azul, roxa, vermelha e verde indicam o limite de significância estatística (LOD) de acordo com a população empregada $\left(\mathrm{F}_{2}\right.$ e $\left.\mathrm{F}_{3}\right)$ e as notas de severidade. 


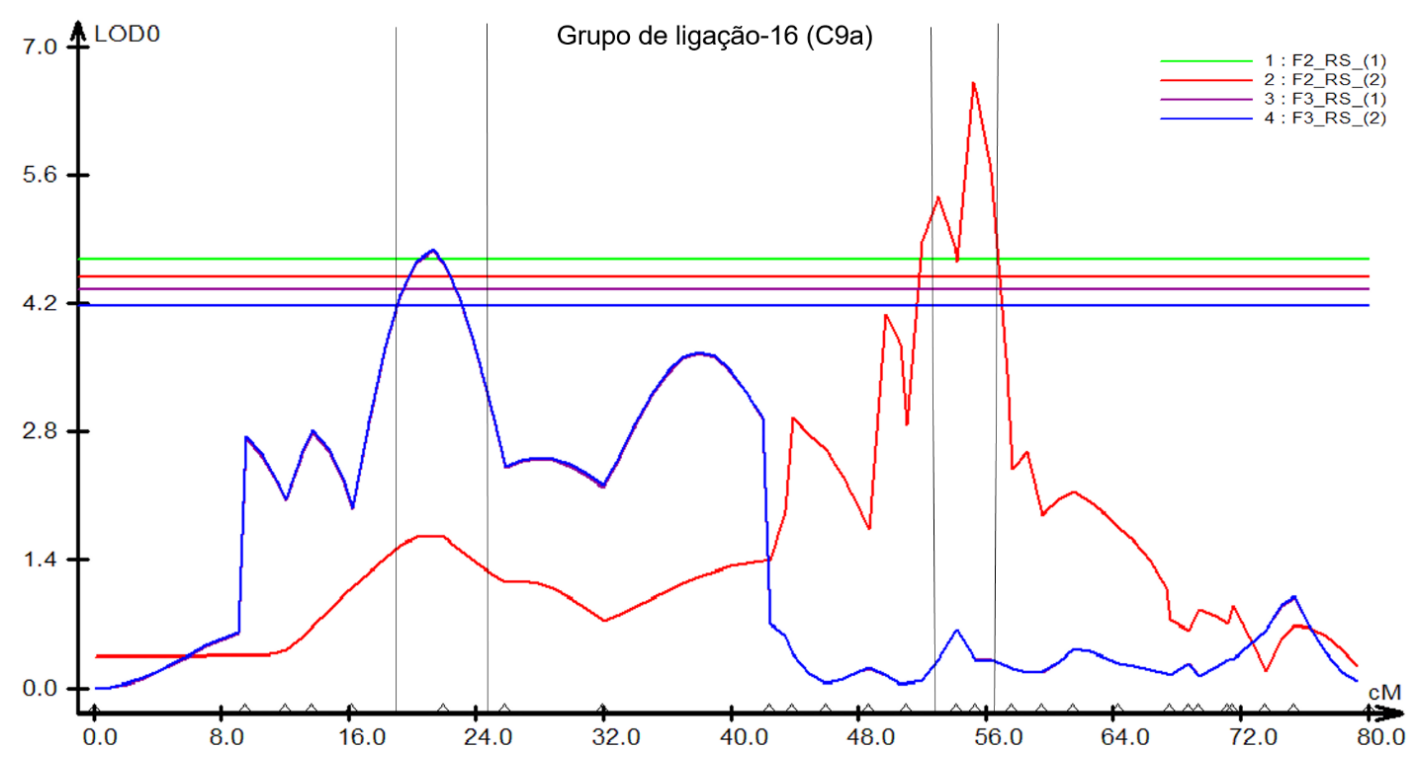

Figura 4-6. QTLs ligados à resistência à murcha de fusário da alface causada por Fusarium oxysporum f. sp. lactucae raça 1 posicionado entre os marcadores [Lsat_1_v5_g9_108)], [Lsat_1_v5_g9_111 e Lsat_1_v5_g9_448] no grupo de ligação 16 (Cromossomo 9a). (LOD = 4,77 e $\mathrm{LOD}=6,61$, respectivamente). As linhas verticais azul, roxa, vermelha e verde indicam o limite de significância estatística (LOD) de acordo com a população empregada $\left(F_{2}\right.$ e $\left.F_{3}\right)$ e as notas de severidade. 

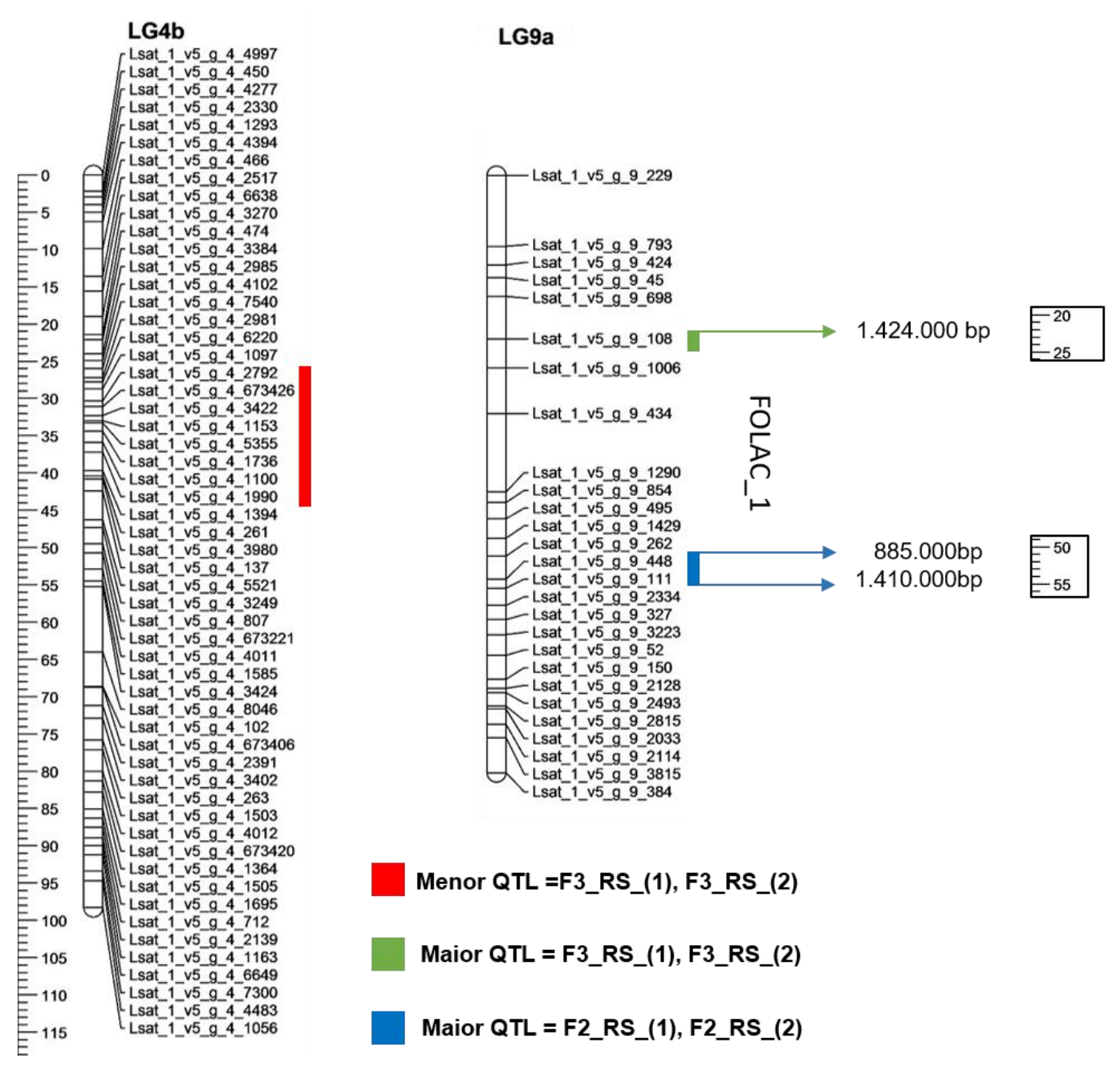
- Lsat_1_v5___9_327 -Lsat_1_v5_9_9_3223 - Lsat_1_v5_9_9552 - Lsat_1_v5_g_9_150 Lsat_1_v5_9_9_2128 - Lsat_1_v5_9_9_2815 (Lsat_1_v5_9_9_2033 Lsat_1 v5_9_9_2114 Lsat_1_v5_9_9_384

Menor QTL =F3_RS_(1), F3_RS_(2)

Maior QTL = F3_RS_(1), F3_RS_(2)

Maior QTL = F2_RS_(1), F2_RS_(2)

Figura 4-7. Localização no mapa genético da alface dos três QTLs associados com à resistência a Fusarium oxyporum f. sp. lactucae raça 1 derivados da cultivar de alface 'Vanda'. As barras indicam as regiões significativas associados com a resistência ao patógeno.

\section{DISCUSSÃO}

5.1. Genotyping-by-sequencing e análise de SNPs - Como evidenciado anteriormente (Ver capítulo 2) existe uma baixa diversidade genética entre os parentais, tendo em vista que pertencem ao mesmo grupo varietal (crespa-verde). Por este motivo o número de SNPs (10.017) gerados no presente estudo é menor em comparação com os valores relatados para outras 
culturas, como arroz (>30.000) (Spindel et al., 2013), trigo (>130.00) (Rutkoski et al., 2013) e Eucalipto (> 80.000) (Gratapaglia et al., 2011) utilizando GBS. Mesmo assim, a estratégia de GBS apresentou um bom desempenho em L. sativa, uma espécie de base genética estreita e elevada homogeneidade, permitindo a análise de um número muito alto de marcadores distribuídos ao longo de todo o seu genoma. A estratégia de GBS aumentou em ordem de milhares o número de polimorfismos analisados quando constratada com as técnicas anteriormente utilizadas nessa tese (RAPD, SCAR, DR analogs, SSR e CAPS), que permitiram, em geral, a análise de poucas centenas de marcadores.

No presente estudo observou-se uma grande proporção de missing data (1.689 no total, em todos os indivíduos) quando comparado com resultados obtidos em outras populações de alface (Truco et al., comunicação pessoal). Isto é esperado na técnica de GBS devido à baixa cobertura de reads, resultante de diversos fatores como, por exemplo, a mistura das amostras com códigos de barras em uma única linha do sequenciador (Barba et al., 2014), os fragmentos do genoma sequenciados com uma cobertura considerada baixa (low depth coverage) fazendo com que alguns loci tenham zero de cobertura em alguns indivíduos (Elshire et al. 2011). Outro detalhe importante é que o DNA a ser utilizado na metodologia de GBS deve ser de elevada qualidade e com uma concentração adequada, estando livre da contaminação de compostos fenólicos, já que estes interferem na digestão das enzimas de restrição e na ligação dos adaptadores, por isso o método de extração adequado é primordial nessa técnica (Wong et al., 2015). No presente trabalho, o DNA foi inicialmente extraído pelo método CTAB, que não é o mais indicado para a plataforma Illumina. Posteriormente foi feita a purificação com colunas [MO BIO Laboratories Carlsbad, CA, USA)] com o objetivo de remover eventuais inibidores da reação de sequenciamento. Essas condições consideradas sub-ótimas podem ter afetado negativamente a qualidade do DNA analisado. No entanto, populações apresentando um sequenciamento com 
valores entre $10 \%$ a $20 \%$ de missing data podem ser utilizadas na construção de mapas genéticos e reduzir erros nas análises tais como a presença de SNPs falsos positivos (Hackett \& Broadfoot, 2003). Bibliotecas menos complexas possuem um número consideravelmente menor de missing data, mas também um menor número de marcadores (Bhatia et al., 2013). A maioria das análises exige um conjunto de dados bem completos (Bhatia et al., 2013). A retirada de marcadores com grande número de missing data é uma etapa necessária antes que os dados de GBS possam ser utilizados para a maioria dos estudos de mapeamento genético. A disponibilidade do genoma de referência e de um mapa de ligação saturado pode evitar a retirada de marcadores da análise de ligação. A partir das análises de ligação 19 indivíduos com menos que 2.5 milhões de reads por amostra (low sequence coverage) foram removidos da análise evitando, desta forma, muitos sítios heterozigóticos e índices de distorção de segregação que tornariam o processo de mapeamento ainda mais complicado.

5.2. Mapeamento genético - A ação gênica em alface governando a resistência a FOLAC raça 1 foi estudada por uma abordagem abrangente envolvendo a combinação de estudos clássicos de herança (Ver capítulo 2) e mapeamento genético e de QTL com marcadores moleculares baseados na tecnologia genotyping-by-sequencing. Inicialmente, observou-se um modelo monogênico dominante com níveis elevados de penetrância na população $F_{2}$. Estudos anteriores indicam que a genética da resistência a FOLAC está sob controle de um ou mais genes com completa ou incompleta dominância (Aruga et al., 2012; Truco et al., comunicação pessoal). A partir da análise genética com base na técnica de GBS, observou-se a presença de duas regiões genômicas, uma no cromossomo 4a e a segunda no cromossomo 9a. Entretanto foi detectado QTLs de maior efeito no LG9 e um adicional no LG4. Provavelmente, o locus maior de resistência a FOLAC raça 1 deve estar localizado próximo na porção mediana do cromossomo 9, 
contribuindo com $40 \%$ e $30 \%$ da variação fenotípica com dados de fenotipagem da $\mathrm{F}_{2}$ e $\mathrm{F}_{3}$, respectivamente.

Níveis elevados na concentração do inóculo em testes em casa de vegetação, método de inoculação, diferentes condições ambientais durante a condução dos ensaios para avaliação da severidade nas populações $\mathrm{F}_{2}$ e $\mathrm{F}_{3}$, podem ter contribuído para uma fenotipagem mais estringente e consequentemente contribuindo para a detecção de genes com efeitos menores. Avaliações em campo e em casa de vegetação têm revelado interações em resposta a FOLAC entre cultivares e linhagens, raças de FOLAC e locais de avaliação (casa de vegetação vs. campo infestado).

Michelmore et al. (2010) avaliando uma população derivada do cruzamento entre ('Valmaine' $x$ 'Salinas 88') $x$ 'Salinas' em condições de campo nos Estados Unidos para resistência a FOLAC raça 1, detectaram quatro QTLs de resistência nos grupos de ligação LG1 (qFUS1.1 e qFUS1.2), LG2 (FUS2) e LG7 (qFUS7.1). Posteriormente, Truco et al. (Comunicação pessoal) no mesmo campo, utilizando 112 indivíduos da população $F_{2}$ do cruzamento entre 'Red Tide' $x$ 'Lolla Rossa', identificaram quatro QTLs associados com a resistência nos grupos de ligação LG1 (qFUS1.1 e qFUS1.2), LG4 (qFUS4.1) e LG8 (qFUS8.1).

No Japão, Aruga et al. (2012) em condições de casa de vegetação determinaram que a resistência a FOLAC raça 2 é controlada por um locus semi-dominante (denominado RRD2). Um mapa de ligação foi construído e o locus RRD2 foi localizado no LG2 (Aruga et al., 2012).

O QTL de resistência a FOLAC raça 1 derivado da cultivar 'Vanda' foi identificado no cromossomo 9. Essa região cromossômica engloba um QTL de resistência ao míldio em condições de casa de vegetação (qDMR9.1), um QTL de resistência de campo ao míldio (qDM9.1) e um locus de resistência à murcha causada por Verticillium dahliae (Ve1) (McHale et al., 2009; Christopoulou et al., 2015a,b) Além disso, três distintos clusters de NBS-LRR e ou RLK estão presentes nos cromossomos 9: MRC9A, MRC9B e MRC9C. MRC9A que co-segrega 
com os QTLs para resistência ao míldio (qDMR9.1, qDMR9.2 e qDMR9.3) e com um gene candidato que codifica um RLK para resistência $V$. dahliae. O cluster MRC9B consiste de um aglomerado de RGC12. No entanto, não existe ainda nenhum fenótipo de resistência conhecido mapeado nesse locus (Christopoulou et al., 2015a,b).

Um QTL de menor efeito (contribuindo com 0,06\% da variação fenotípica com os dados de fenotipagem da $\mathrm{F}_{3}$ ) foi identificado no cromossomo 4 e está na mesma região cromossômica que engloba o locus Dm4. Esse QTL está localizado em um hot-spot de genes de resistência onde também residem importantes genes/fatores de resistência a diferentes patógenos, tais como os setes loci de resistência ao míldio (Dm4,Dm7, Dm11, Dm24, Dm38, Dm44 e Dm48). É interessante mencionar que um QTL de resistência a murcha de fusário em alface (q.FUS4.1) foi identificado no cromossomo 4 (Christopoulou et al., 2015a,b), em uma região diferente daquela encontrada no presente trabalho.

Os cromossomos 4 e 9 contém mais que $89 \%$ de TNLs. Membros de cada família multigênica normalmente são encontrados em clusters no mesmo cromossomo (pelo menos 68\% das famílias de genes) com exceção da família RGC12 com distribuição ampla no genoma e da família RGC14 presente em quatro cromossomos. A família RGC12 é a segunda maior família com 55 membros presentes em seis cromossomos, dos quais 20 membros estão presentes no cromossomo 9 e 19 no cromossomo 4. Três RGC14 estão presentes no cromossomo 9 (Christopoulou et al., 2015a,b). De acordo com esses mesmos autores, as múltiplas localizações cromossômicas de algumas famílias devem-se ao agrupamento de mais de um gene que evoluíram lentamente em famílias individuais baseada no threshold de $70 \%$ de identidade de sequência. Vários clusters são homogêneos, constituindo de uma única família gênica (MRC1, MRC4, MRC3, MRC8A e MRC8B). Já outros são bastante complexos contendo múltiplos TNLs e CNLs. A arquitetura genômica da alface no MRC4 está envolvida com genes que confere 
resistência genética no genoma de alface e em plantas em geral (Meyers et al., 1998; Michelmore \& Meyers, 1998). Sequências do genoma revelam a complexidade deste loci com predominância da família de genes RGC12 localizados em clusters cercados por genes relacionados ou não com resistência. Dentro desse cluster, a família NBS-LRR controla a maioria dos fenótipos de resistência que são altamente conservados em quatro genótipos de alface como, L. sativa cv. 'Salinas', 'Diana', 'Valmaine' e L. serriola 'US96UC23'.

A relativa importância de QTLs de maior efeito, a presença de QTLs em clusters e efeitos fenotípicos refletem uma rápida domesticação impulsionada pela forte seleção direcional (Riesenberg et al., 2002; Ross-Ibarra, 2005), ao passo que a maioria dos QTLs de menor efeito tendem a refletir um processo gradual com vários eventos de domesticação (Burke et al., 2007). Os genes em clusters são mais facilmente domesticados do que genes mais dispersos no genoma (Burke et al. 2007). Alternativamente, os clusters podem ser resultado de genes individuais com efeitos pleiotrópicos para várias características. De qualquer maneira, análises mais detalhadas são necessárias para obter conclusões mais definitivas (Hartman et al., 2013).

Uma característica interessante dos fatores de resistência mapeados nos cromossomo 4 e cromossomo 9 é que eles se localizam em clusters geneticamente bem próximos. A identificação de um marcador molecular associado especificamente a um desses fatores de resistência pode representar uma tarefa de difícil execução. Em geral, as linhagens de melhoramento genético são constituídas por diferentes loci provenientes de um conjunto diverso de acessos/cultivares. Desta forma, é pouco provável que estes materiais genéticos possam compartilhar um mesmo marcador capaz de identificar todas as diferentes variantes alélicas. Dessa maneira, somente marcadores em extrema ligação com gene de interesse poderão permitir a identificação do fator ou fatores de resistência a FOLAC raça 1. De qualquer forma, a existência de um QTL de efeito maior para resistência a FOLAC raça 1 deve facilitar um mapeamento mais pontual e a potencial clonagem 
de genes nessas regiões genômicas do cromossomo 9. A partir dessas informações será possível sintetizar um conjunto de primers que anelem em regiões do genoma em forte ligação com os fatores de resistência, propiciando assim o desenvolvimento de marcadores altamente específicos que serão convertidos para uso de rotina (via PCR) para seleção assistida nos programas de melhoramento genético desta hortaliça.

\section{REFERÊNCIAS BIBLIOGRÁFICAS}

ARUGA, D.; TSUCHIYA, N.; MATSUMURA, H.; MATSUMOTO, E. \& HAYASHIDA, N. 2012. Analysis of RAPD and AFLP markers linked to resistance to Fusarium oxysporum $\mathrm{f}$. sp. lactucae race 2 in lettuce (Lactuca sativa L.). Euphytica 187:1-9.

ARUMUGANATHAN, K. \& EARLE, E.D. 1991. Estimation of nuclear DNA content of plants by flow cytometry. Plant Molecular Biology Reporter 9: 229-241.

BARBA, P.; CADLE-DAVIDSON, L.; HARRIMAN, J.; GLAUBITZ, J.C.; BROOKS, S.; HYMA, K. \& REISCH, B. 2014. Grapevine powdery mildew resistance and susceptibility loci identified on a high-resolution SNP map. Theoretical and Applied Genetics 127:73-84.

BHATIA, D.; WING, R.A. \& SINGH, K. 2013. Genotyping by sequencing, its implications and benefits. Crop Improvement 40:101-111.

BOITEUX, L.S.; FONSECA, M.E.N. \& SIMON, P.W. 1999. Effects of plant tissue and DNA purification method on randomly amplified polymorphic DNA based genetic fingerprinting analyses in carrot. Journal of the American Society for Horticultural Science 124:32-38.

BRADBURY, P.J.; ZHANG, Z.; KROON, D.E.; CASSTEVENS, T.M.; RAMDOSS, Y. \& BUCKLER, E.S. 2007. TASSEL: software for association mapping of complex traits in diverse samples. Bioinformatics 23:2633-2635.

BURKE, J.M.; BURGER, J.C \& CHAPMAN, M.A. 2007. Crop evolution: from genetics to genomics. Current Opinion in Genetics Development 17:525-532.

CABRAL, C.S. 2012. Caracterização de isolados de Fusarium oxysporum f. sp. lactucae das Regiões Sul e Sudeste do Brasil e identificação de acessos de alface resistentes. Dissertação de Mestrado em Fitopatologia.Universidade Federal Rural de Pernambuco. Recife, Brasil.

CABRAL, C.S. \& REIS, A. 2013. Screening of lettuce accessions for resistance to Fusarium oxysporum f. sp. lactucae race 1. Tropical Plant Pathology 38:272-281. 
CABRAL, C.S.; SUINAGA, F.A.; REIS, A.; FONSECA, M.E.N. \& BOITEUX, L.S. 2015. Herança da resisteência à murcha causada por Fusarium oxysporum f. sp. lactucae raça 1 em um acesso de alface crespa. In: $8^{0}$ Congresso de Melhoramento de Plantas, Goiânia, CD-ROM.

CHRISTOPOULOU, M.; MCHALE, L.K.; KOZIK, A.; REYES-CHIN WO, S.; WROBLEWSKI, T. \& MICHELMORE, R.W. 2015a. Dissection of two complex clusters of resistance genes in lettuce (Lactuca sativa). Molecular Plant-Microbe Interactions 28:751-765.

CHRISTOPOULOU, M.; REYES-CHIN WO, S.; KOZIK, A.; MCHALE, L.K.; TRUCO, M.J.; WROBLEWSKI, T. \& MICHELMORE, R.W. 2015b. Genome-wide architecture of disease resistance genes in lettuce. G3: Genes| Genomes| Genetics 5: 2655-2669.

COLLARD, B.C.Y.; JAHUFER, M.Z.Z.; BROUWER, J.B. \& PANG, E.C.K. 2005. An introduction to markers, quantitative trait loci (QTL) mapping and marker-assisted selection for crop improvement: the basic concepts. Euphytica 142:169-196.

DESCHAMPS, S.; LLACA, V. \& MAY, G.D. 2012. Genotyping-by-sequencing in plants. Biology 3:460-483.

DOERGE, R.W. \& CHURCHILL, G.A.1996. Permutation tests for multiple loci affecting a quantitative character. Genetics 142: 285-294.

ELSHIRE, R.J.; GLAUBITZ, J.C.; SUN, Q.; POLAND, J.A.; KAWAMOTO, K.; BUCKLER, E.S. \& MITCHELL, S.E. 2011. A robust, simple genotyping-by-sequencing (GBS) approach for high diversity species. Plos One 6:e19379.

FUJINAGA, M.; OGISO, H.; TSUCHIYA, N. \& SAITO, H. 2001. Physiological specialization of Fusarium oxysporum oxysporum f. sp. lactucae, a causal organism of fusarium root rot of crip head lettuce. Journal of General Plant Pathology 67:205-206.

FUJINAGA, M.; OGISO, H.; TSUCHIYA, N. \& SAITO, H. 2003. Race 3, a new race of Fusarium oxysporum f. sp. lactucae determined by a differencial system with commercial cultivars. Journal of General Plant Pathology 69:23-28.

GANAL, M.W.; ALTMANN, T. \& RODER, M.S. 2009. SNP identification in crop plants. Current Opinion in Plant Biology 12:211-217.

GILARDI, G.; FRANCO ORTEGA, S.; RIJSWICK, P.C.J.; ORTU, G.; GULLINO, M.L. \& GARIBALDI, A. 2016. A new race of Fusarium oxysporum f. sp. lactucae of lettuce. Plant Pathology. 
GLAUBITZ, J.C.; CASSTEVENS, T.M.; LU, F.; HARRIMAN, J.; ELSHIRE, R.J.; SUN, Q. \& BUCKLER, E.S. 2014. TASSEL-GBS: a high capacity genotyping by sequencing analysis pipeline. Plos One 9:e90346.

GRATTAPAGLIA, D.; SILVA-JUNIOR, O. B.; KIRST, M.; DE LIMA, B.M.; FARIA, D.A. \& PAPPAS JR, G. J. 2011. High-throughput SNP genotyping in the highly heterozygous genome of Eucalyptus: assay success, polymorphism and transferability across species. BMC Plant Biology. 11:65.

HACKETT, C.A. \& BROADFOOT, L.B. 2003. Effects of genotyping errors, missing values and segregation distortion in molecular marker data on the construction of linkage maps. Heredity 90:33-38.

HAMMOND-KOSACK, K.E. \& JONES, J.D.G. 1997. Plant disease resistance genes. Annual Review of Plant Physiology and Plant Molecular Biology 48:575-607.

HARTMAN, Y.; HOOFMAN, D.A.; SCHRANZ, M.E. \& VAN TIENDEREN, P.N. 2013. QTL analysis reveals the genetic architecture of domestication traits in crisphead lettuce. Genetic Resources and Crop Evolution 60:1487-1500.

HE, J.; ZHAO, X.; LAROCHE, A.; LU, Z.X.; LIU, H. \& LI, Z. 2014. Genotyping-bysequencing (GBS), an ultimate marker-assisted selection (MAS) tool to accelerate plant breeding. Frontiers in Plant Science 5:484.

JANSEN, R.C. \& STAM, P. 1994. High resolution of quantitative traits into multiple loci via interval mapping. Genetics 136:1447-1455.

KOSAMBI, D.D. 1944. The estimation of map distance from recombination values. Annuaire of Eugenetics 12:172-175.

MCHALE, L.K.; TRUCO, M.J.; KOZIK, A.; LAVELLE, D.O.; OCHOA, O.E.; WROBLEWSKI, T.; KNAPP, S.J. \& MICHELMORE, R.W. 2009. The genomic architecture of disease resistance in lettuce. Theoretical and Applied Genetics 118:565-580.

MCPHEE, K.E.; INGLIS, D.A.; GUNDERSEN, B. \& COYNE, C.J. 2012. Mapping QTL for Fusarium wilt race 2 partial resistance in pea (Pisum sativum). Plant Breeding 131:300306.

MEYERS, B.C.; CHIN, D.B.; SHEN, K.A.; SIVARAMAKRISHNAN, S.; LAVELLE, D.O.; ZHANG, Z. \& MICHELMORE, R.W. 1998. The major resistance gene cluster in lettuce is highly duplicated and spans several megabases. Plant Cell 10:1817-1832. 
MICHELMORE, R.W. \& MEYERS, B.C. 1998. Clusters of resistance genes in plants evolve by divergent selection and a birth-and-death process. Genome Research 8:1113-1130.

MICHELMORE, R.W. 2010. Genetic variation in lettuce. California leafy greens research program,calgreens.org/control/uploads/Michelmore_Variation_report_20092010_final_(2)1.pdf.

MOU, B. 2008. Lettuce. In: Prohens, J.; Nuez, F. \& Carena, M.J. (eds.). Handbook of Plant Breeding. Vegetables I. Asteraceae, Brassicaceae, Chenopodiaceae, and Cucurbitaceae. Springer. New York. p.75-116.

PASQUALI, M.; GILARDI, G.; GULLINO, M.L. \& GARIBALDI, A. 2003. Fusarium oxysporum f. sp. lactucae on lettuce: vegetative compatibility and RAPD analysis. Phytopathology 53:73-75.

PASQUALI, M.; DEMATHEIS, F.; GULLINO, M.L. \& GARIBALDI, A. 2007. Identification of race 1 of Fusarium oxysporum f. sp. lactucae on lettuce by inter-retrotranposon sequencechacarterized amplified region technique. Phytopathology 97:987-996.

POLAND, J.A. \& RIFE, T.W. 2012. Genotyping-by-sequencing for plant breeding and genetics. The Plant Genome 5: 92-102.

RIESEBERG, L.H.; WIDMER, A.; ARNTZ, A.M. \& BURKE, J.M. 2002. Directional selection is the primary cause of phenotypic diversification. Proceedings of the National Academy of Sciences 99:12242-12245.

ROSS-IBARRA, J. 2005. Quantitative trait loci and the study of plant domestication. Genetics of Adaptation 123:197-204.

RUTKOSHI, J.E.; POLAND, J.; JANNINK, J. \& SORRELLS, M.E. 2013. Imputation of unordered markers and the impact on genomic selection accuracy. Genes/Genomes/Genetics 3:427-439.

SANTOS, J.R.M. 1996. Methodology for screening tomato to Fusarium wilt, Verticillium wilt, gray leaf spot, early blight, and Septoria leaf spot. In: Proceedings of the International Symposium on Tropical Tomato Diseases. Recife PE, Brazil. pp. 164-166.

SCOTT, J.C.; GORDON, T.R.; KIRKPATRICK, S.C.; KOIKE, S.T.; MATHERON, M.E.; OCHOA, O.E.; TRUCO, M.J. \& MICHELMORE, R.W. 2012. Crop rotation and genetic resistance reduce risk of damage from Fusarium wilt in lettuce. California Agriculture 66:20-24. 
SEKHWAL, M.K.; LI, P.; LAM, I.; WANG, X.; CLOUTIER, S. \& YOU, F.M. 2015. Disease resistance gene analogs (RGAs) in plants. International Journal of Molecular Sciences $16: 19248-19290$

SPINDEL, J.; WRIGHT, M.; CHEN, C.; COBB, J.; GAGE, J.; HARRINGTON, S.; LORIEUX, M.; AHMADI, N. \& McCOUCH, S. 2013. Bridging the genotyping gap: using genotyping by sequencing (GBS) to add high-density SNP markers and new value to traditional biparental mapping and breeding populations. Theoretical and Applied Genetics 126:26992716.

STOFFEL, K.; VAN LEEUWEN, H.; KOZIK, A.; CALDWELL, D.; ASHRAFI, H.; CUI, X.; TAN, X.; HILL, T.; REYES-CHIN-WO, S.; TRUCO, M.J. \& MICHELMORE, R.W. 2012. Development and application of a 6.5 million feature Affymetrix Genechip ${ }^{\circledR}$ for massively parallel discovery of single position polymorphisms in lettuce (Lactuca spp.). BMC Genomics 13:185.

TESTER, M. \& LANGRIDGE, P. 2010. Breeding technologies to increase crop production in a changing world. Science 327:818-822.

TRUCO, M.J.; ASHRAFI, H.; KOZIK, A.; LEEUWEN, H.V.; BOWERS, J.; REYES-CHIN WO, S.; STOFFEL, K.; XU, H.; HILL, T.; DEYNZE, A.V. \& MICHELMORE, R.W. 2013. An ultra-high-density, transcript-based, genetic map of lettuce. G3. Genes/genome/ genetics 3:617-631.

VAN OOIJEN, J.W. 2006. JoinMap®4.0 Software for the calculation of genetic linkage maps in experimental populations. Kyazma BV, Wageningen, Netherlands.

VENTURA, J.A. \& COSTA, H. 2008. Fusarium wilt caused by Fusarium oxysporum on lettuce in Espirito Santo, Brazil. Plant Disease 92:976.

VOORRIPS, R.E. 2002. MapChart: Software for the graphical presentation of linkage maps and QTLs. The Journal of Heredity 93:77-78.

WANG, S.; BASTEN, C.J. \& ZENG, Z.B. 2005. Windows QTL Cartographer version 2.5. Statistical Genetics. North Carolina State University, Raleigh.

WONG, M.M.; GUJARIA-VERMA, N.; RAMSAY, L.; YUAN, H.Y.; CARON, C.; DIAPARI, M.; VANDERBERG, A. \& BETT, K.E. 2015. Classification and characterization of species within the genus lens using Genotyping-by-Sequencing (GBS). Plos one 10:e0122025.

WOUW, M.J.V.D.; TREUREN, R.V. \& HINTUM, T.J.L.V. 2011. Authenticity of old cultivars in genebank collections: a case study on lettuce. Crop Science 51:736-746. 
YAMAUCHI, N.; SHIMAZU, J.; HORIUCHI, S.; SATOU, M. \& SHIRAKAWA, T. 2004. Physiological races and vegetative compatibility groups of butterhead lettuce isolates of Fusarium oxysporum f. sp. lactucae in Japan. Journal of General Plant Pathology 70:308313. 